Georgia State University

ScholarWorks @ Georgia State University

4-29-2009

\title{
CEO Risk Taking and Firm Policies: Evidence from CEO Employment History
}

Lingling Wang

Follow this and additional works at: https://scholarworks.gsu.edu/finance_diss

Part of the Finance and Financial Management Commons

\section{Recommended Citation}

Wang, Lingling, "CEO Risk Taking and Firm Policies: Evidence from CEO Employment History." Dissertation, Georgia State University, 2009.

doi: https://doi.org/10.57709/1059009

This Dissertation is brought to you for free and open access by the Department of Finance at ScholarWorks @ Georgia State University. It has been accepted for inclusion in Finance Dissertations by an authorized administrator of ScholarWorks @ Georgia State University. For more information, please contact scholarworks@gsu.edu. 


\section{Permission to Borrow}

In presenting this dissertation as a partial fulfillment of the requirements for an advanced degree from Georgia State University, I agree that the Library of the University shall make it available for inspection and circulation in accordance with its regulations governing materials of this type. I agree that permission to quote from, or to publish this dissertation may be granted by the author or, in his/her absence, the professor under whose direction it was written or, in his absence, by the Dean of the Robinson College of Business. Such quoting, copying, or publishing must be solely for scholarly purposes and does not involve potential financial gain. It is understood that

any copying from or publication of this dissertation which involves potential gain will not be allowed without written permission of the author.

Lingling Wang

signature of author 


\section{Notice to Borrowers}

All dissertations deposited in the Georgia State University Library must be used only in accordance with the stipulations prescribed by the author in the preceding statement.

The author of this dissertation is:

Lingling Wang

315 Rams Way, Tucker, GA 30084

The director of this dissertation is:

Harley E. Ryan

Department of Finance

J. Mack Robinson College of Business

Georgia State University

35 Broad Street

Atlanta, GA 30303

Users of this dissertation not regularly enrolled as students at Georgia State University are required to attest acceptance of the preceding stipulations by signing below. Libraries borrowing this dissertation for the use of their patrons are required to see that each user records here the information requested.

Name of User
Address

Date 
CEO Employment History and Risk-taking in Firm Policies

\section{BY}

Lingling Wang

A Dissertation Submitted in Partial Fulfillment of the Requirements for the Degree of

Doctor of Philosophy

in the Robinson College of Business

of

Georgia State University

GEORGIA STATE UNIVERSITY

ROBINSON COLLEGE OF BUSINESS

2009 
Copyright by Lingling Wang 2009 


\title{
ACCEPTANCE
}

This dissertation was prepared under the direction of Lingling Wang's Dissertation Committee. It has been approved and accepted by all members of that committee, and it has been accepted in partial fulfillment of the requirements for the degree of Doctor in Philosophy in Business Administration in the Robinson College of Business of Georgia State University.

\author{
H. Fenwick Huss \\ Dean \\ Robinson College of Business
}

Dissertation Committee:

Harley E. Ryan (Chair)

Jayant R. Kale

Omesh Kini

Conrad S. Ciccotello 


\section{ACKNOWLEDGEMENT}

I would like to gratefully and sincerely thank Harley E. Ryan, my dissertation committee chair, for his guidance, patience and enormous support during my graduate studies at Georgia State University. I am grateful to valuable advice from my dissertation committee: Jayant R. Kale, Omesh Kini and Conrad S. Ciccotello. I thank Isabel Tkatch for her advice on econometrics. I have benefited from discussions with Vikas Agarwal, Zinat Alam, Malcolm Baker, Mark Chen, Peter Eisemann, Gerald Gay, Jonathan Godbey, Lixin Huang, Reza Mahani, Costanza Meneghetti, Shabnam Mousavi, Jaideep Shenoy, Ilya Strebulaev, Vallapuzha Sandhya, Anand Venkateswaran, Ryan Williams, Baozhong Yang, and seminar participants at 2009 FMA $\mathrm{PhD}$ Consortium, Clemson University, Drexel University, Georgia State University, Florida Atlantic University, Rensselaer Polytechnic Institute (RPI), Texas Christian University, Tulane University, and University of Kansas. I especially want to thank my husband, Yan, for his continuous support during my doctoral study and for his insightful comments on my dissertation. My son, Daniel, has been the greatest motivation for me to strive in this profession. I am indebted to my parents, Yanhai and Shuhua, and my aunt, Ping, for their encouragement and unconditional love. I dedicate this dissertation to my family. I am responsible for any remaining errors. 


\author{
ABSTRACT \\ CEO Employment History and Risk-taking in Firm Policies \\ By \\ Lingling Wang
}

April 28, 2009

Committee Chair: Dr. Harley E. Ryan

Major Department: Finance

I propose that CEO employment history is an observable characteristic that reveals the CEO's unobservable risk-taking preferences. I hypothesize that CEOs that change employers more frequently (mobile CEOs) have a propensity to bear risk and implement riskier firm policies. Using a sample of S\&P 1500 CEOs, I find that firms are more likely to hire mobile CEOs when the firm's prior risk is high, firm-specific human capital is less important, the prior CEO turnover is forced, the prior CEO has a shorter tenure and the board is smaller and has fewer insiders. Mobile CEOs increase financial leverage, invest more in advertising and less in capital expenditures, and increase firm-specific risk. Mobile CEOs invest more (less) in R\&D in homogenous (heterogeneous) industries where firm-specific knowledge is less (more) important in making investment decisions. Shareholders react positively to appointments of CEOs who change employers more frequently. I find no difference in long-run accounting performance for CEOs with different employment histories. Firms' annual stock returns and sales growth are higher for CEOs who change employers more frequently. The cost of debt increases after the firm appoints a mobile CEO. These findings suggest that lower CEO risk aversion and the potential risk-shifting from shareholders to bondholders are sources of shareholder value increases. In sum, my findings provide evidence that CEO employment history is an observable characteristic that reveals the risk-taking preference of the CEO. 


\section{CEO Employment History and Risk-taking in Firm Policies}

\section{Introduction}

A prevailing perception in the popular press and academic research is that managers have different styles when they make decisions in their firms. ${ }^{1}$ However, evidence is scant on why there are different managing styles, why firms choose different managing styles, and how different managing styles influence firm policies. ${ }^{2}$ Anecdotal evidence suggests that the employment history conveys important information about the CEO. For instance, when a firm announces the appointment of a new CEO, it usually gives a detailed description of the CEO's employment history. ${ }^{3}$ In this paper, I propose that CEO employment history is an observable characteristic that reveals the CEO's risk-taking preferences. Because accepting a position with a different employer involves numerous uncertainties, switching employers indicates a manager's willingness to bear risk. Therefore, I propose that CEOs that change employers more frequently have a propensity to bear more risk and implement riskier policies in their firms. Using five measures of employment history, I provide empirical evidence on how employment history relates to a firm's choice of a new CEO and the relation between the new CEO's employment history and changes in the riskiness of firm policies. My evidence supports the premise that a CEO's employment history provides information about her propensity to bear risk.

Research supports the idea that CEOs who change employers more frequently are prone to bear more risk. Job search models in labor economics show that less risk-averse employees are

\footnotetext{
${ }^{1}$ For example, an article in the Wall Street Journal on August $8^{\text {th }}, 2007$, titled "Chrysler's New 'Tough-as-Nails' CEO", discusses the aggressive and controversial managing style of Robert Nardelli. Examples of academic research include Bertrand and Schoar (2003), Kaplan, Klebanov, and Sorensen (2008) and Graham, Harvey, and Puri (2008).

${ }^{2}$ A few recent exceptions include Kaplan et al. (2008) and Graham et al. (2008). They use survey data or psychological test results to study CEO personalities or psychological traits. Similar to the approach in this paper, Malmendier and Tate $(2005,2007)$ use observable information to infer the overconfidence level of managers.

3 For example, see the announcement of Wachovia's new CEO, Robert K. Steel, in the Wall Street Journal on July $10^{\text {th }}, 2008$.
} 
more likely to change jobs, ceteris paribus (e.g. Harris and Weiss, 1984, Pissarides, 1974, 1976 and Vesterlund, 1997). Job turnover theories suggest that CEOs who change employers less frequently are likely to be more risk averse because they make greater human capital investments in a firm (e.g. Becker, 1962, and Jovanovic, 1979b) or achieve better CEO-firm match qualities (e.g., Jovanovic, 1979a and Mortensen, 1978). Organizational behavior studies provide survey evidence that people with more employer changes have higher risk propensities (e.g., Nicholson et al., 2005 and Pfeifer, 2008) and use the number of employer changes as an empirical proxy for the willingness to engage in risky behavior (e.g., Nicholson and West, 1988, and Nicholson et al 2005).

Motivated by these studies, I construct five employment proxies that I propose will provide information about the unobservable risk-taking trait of the CEO. The first proxy is the number of employers for which a CEO has worked. To control for differences in CEOs' career lengths, I construct a second proxy, the number of employers per year, defined as the number of employers divided by the CEO's career length. Some CEOs change employers very frequently at the beginning of their careers and remain in one firm for a long time. Other CEOs change employers frequently throughout their careers. To control for these different patterns, I create a third proxy that captures the recency of a CEO's employer changes. CEOs that have worked for multiple employers are more likely to develop diversified experience. To proxy for the degree of diversification of the CEO's firm experience, I construct a fourth proxy based on time durations a CEO spends with different employers. Some CEOs change employers but remain in the same industry and other CEOs work for multiple employers in different industries. To control for differences in industry experience, I construct a fifth proxy based on time durations a CEO spends in different industries. The first three proxies measure the number, the frequency and the 
recency of employer changes and the last two proxies capture the degree of diversification for a CEO's firm or industry experience.

The literature in labor economics and organizational behavior, discussed above, implies that CEOs that change employers more frequently (henceforth, mobile CEOs) are less risk averse, ceteris paribus. To shed light on the relation between CEO employment history and risk-taking in firm policies, I seek to answer four related research questions. First, why does a firm hire a mobile CEO? Assuming that the decision to hire a CEO is a constrained optimum, one would expect the firm's need to implement risky policies, firm characteristics, corporate governance, the prior CEO's characteristics, and industry conditions to influence this decision. Second, do mobile CEOs implement riskier firm policies and increase firm risk? I expect mobile CEOs to implement riskier firm policies based on the argument that employment history can reflect a person's risk-taking preference. As a result of riskier firm policies, one would also expect mobile CEOs to increase firm risk. Third, do shareholders and bondholders react differently to appointments of mobile CEOs? Although shareholders can diversify firm-specific risk by holding a diversified portfolio, managers' income and human capital highly depend on one firm and cannot be easily diversified (e.g., Fama 1980). This argument implies that shareholders would generally prefer less risk-averse CEOs, ceteris paribus. If mobile CEOs have a higher propensity to bear risk, I expect shareholders to react positively to appointments of mobile CEOs. Since bondholders have a fixed claim on the firm's assets, I expect bondholders to react negatively to appointments of mobile CEOs. In anticipation of an increase in firm risk, bondholders would also require a higher return following the appointment of a mobile CEO. Fourth, does long-run stock and operating firm performance differ for CEOs with different employment histories? If boards of directors optimally choose the right CEO to match firm 
needs, then one would not expect mobile CEOs to perform differently than other CEOs. Analysis on long-run performance provides evidence on the efficiency of CEO-firm matches. Taken together, the analysis of firm risk, stock price and operating performance should shed light on the sources of firm value gains that relate to CEO employment history.

To provide answers to these four research questions, I examine CEO hiring decisions and the changes in firm policies implemented by the new CEO after the CEO turnover year for a sample of S\&P 1500 CEOs and 5,125 firm years from 1992 to 2007. A perusal of the data reveals significant dispersion in CEOs' employment histories. As of 2005, among 1,144 CEOs from non-finance and non-utility S\&P 1500 firms, 189 CEOs (16.52\%) have worked for only one employer and 254 CEOs $(22.20 \%)$ have worked for at least five employers. Some CEOs (for example, David O'Reilly of Chevron) never change employers and some CEOs (for example, Terry L. Hall of GenCorp Inc.) change employers every three years. Three hundred and forty six CEOs (30.24\%) spent their entire careers in one industry and 190 CEOs (16.61\%) worked in four or more industries. These differences in CEO employment history provide a suitable sample for testing the relation between the frequency of a CEO's employer changes and the riskiness of the CEO’s policies.

Using this sample, I first examine why firms hire mobile CEOs. I find that firms are more likely to hire mobile CEOs when the firm's firm-specific human capital is less important, firm risk is high, the prior CEO turnover is forced, the prior CEO has a shorter tenure and the board is smaller and has fewer insiders. In the presence of negative industry shocks, firms prefer to hire CEOs with diversified industry experience. Examining changes in firm policies after CEO turnovers, I find mobile CEOs increase financial leverage, invest more in advertising and less in capital expenditures. Mobile CEOs invest more in R\&D in homogenous industries where firm- 
specific knowledge is less important in making investment decisions and invest less in R\&D in heterogeneous industries where the firm-specific knowledge is more important. Mobile CEOs also increase firm-specific risk. These results support my hypothesis that mobile CEOs engage in riskier firm policies. The levered CAPM beta remains constant, but unlevered CAPM beta decreases. I also examine how CEO employment history affects betas estimated from a fourfactor model (Fama-and-French three factors plus a momentum factor). I find mobile CEOs increase the book-to-market beta, which suggests that mobile CEOs change the growth aspect of their firms. These findings are robust to controls for the CEO-firm match endogeneity and the inclusion of an extensive set of factors that have been shown to impact financing and investment firm policies, including firm policies prior to the year of CEO turnover, firm profitability, Tobin's Q, firm age, firm size, industry concentration, activist institutional ownership, surplus cash, whether directors receive equity-based compensation, CEO age, CEO tenure, CEO compensation vega and delta, CEO founder status, the number of functional areas the CEO has worked in, whether the CEO worked in the finance area, whether the CEO has an MBA degree, whether the CEO is an insider or outsider, industry and year fixed effects. I obtain similar results when I use a principal component based on the five employment history variables to proxy for the CEO employment history. To control for the possibility that CEO hiring decisions and the riskiness of firm policies are simultaneously determined, I estimate a system of simultaneous equations and obtain similar results.

Consistent with the notion that managers significantly impact firm policies (e.g., Bertrand and Schoar, 2003), my parameter estimates suggest that the influence of CEO on firm policies is economically significant. Holding other explanatory variables at their respective means, I find that allowing a CEO's number of employers to increase from 1 to 5 (approximately $25^{\text {th }}$ 
percentile to $75^{\text {th }}$ percentile) increases the market leverage by $4.8 \%$. Based on the mean market leverage of $17 \%$, this result implies an average increase of $27.12 \%$ for market leverage. In comparison, increasing firm size from $25^{\text {th }}$ percentile to $75^{\text {th }}$ percentile increases market leverage by $4.17 \%$. The influence of CEO employment history is higher than the influence of firm size. The increases in R\&D expenditures $(0.8 \%$, a $27.69 \%$ increase) and advertising expenditures $(0.8 \%$, a $61.13 \%$ increase $)$ are also comparable to the influence of firm size.

Given differences in firm policies, I examine how differences in CEO employment history affect shareholders' wealth and firm performance. Shareholders react positively to appointments of CEOs with more employer changes. For forced CEO turnovers, the announcement returns are on average positive if the firm appoints a CEO with at least four employer changes and are on average negative for CEOs with no employer change. For unforced CEO turnovers, the announcement returns for CEOs with at least four employer changes are positive and statistically significant, but the announcement returns for CEOs with no employer change are slightly negative or not different from zero. The reactions appear to be economically significant. For instance, the four-day reaction to an unforced turnover when the new CEO has changed employer at least four times is $1.46 \%$. Based on the mean market capitalization of 9.039 billion dollars, this result implies an average wealth increase of 131.97 million dollars. These findings are similar for both insider and outsider successions. A cross-sectional regression of cumulative abnormal returns (CARs) indicates that the number of employers a CEO has worked for relates positively to the CARs. This result is robust to controls for whether the CEO has an MBA degree, the number of functional areas the CEO has worked in, whether the CEO has worked in the finance area, firm size and whether the prior CEO was forced out. These findings support the argument that mobile CEOs are less risk averse, which mitigates the shareholder-manager 
conflict due to different attitudes toward risk.

I find no difference in long-run accounting performance for CEOs with different numbers of employer changes. However, annual stock returns and sales growth are higher for CEOs with more employer changes. Taken together, the findings that mobile CEOs increase financial leverage and firm-specific risk, do not improve accounting performance, but improve stock performance suggest a potential risk shifting from shareholders to bondholders as one source of shareholder value increase. In support of the risk-shifting explanation, I find that firms that appoint mobile CEOs increase bond spreads and downgrade bond ratings after CEO appointments.

In summary, my evidence indicates that the riskiness of the CEO's policies is related to his employment history. These findings suggest that CEO employment history is an observable characteristic that reveals the unobservable risk-taking preferences of CEOs. Therefore, employment history can help boards of directors identify management styles and achieve better CEO-firm matches. My study relates to the literature that shows that CEOs' managing styles and education (Bertrand and Schoar, 2003), psychological traits (e.g., Graham, Harvey, and Puri, 2008; Malmendier and Tate, 2005, 2007; Hackbarth, 2007), personalities (Kaplan, Klebanov, and Sorensen, 2008), and functional areas (e.g. Hambrick, 2007) influence firm policies and success. My findings complement the results in Graham et al. (2008) who find that firm policies relate to CEOs' risk-taking traits as measured by a psychological survey.

The rest of the article proceeds as follows. In section 2, I discuss why employment history conveys information about the CEO's risk-taking preferences. I also develop testable empirical hypotheses on CEO hiring decisions and firm policies in this section. Section 3 presents data, variable construction and summary statistics. Section 4 presents the results on the CEO-firm 
match. Section 5 studies the impact of CEO employment history on firm policies and firm risk. I present results on market reactions and firm performance in Section 7 and influence on bondholders in Section 8. Section 9 concludes the paper. Appendix A summarizes variable constructions for all firm and industry variables. Appendix B includes robustness tables.

\section{Conceptual Background and Hypothesis Development}

\subsection{Employment History and Risk Taking}

Switching employers involves numerous uncertainties, such as the suitability of the new job, the quality of the working environment, the relationships with the new managers or co-workers, the likelihood of success in the new firm, and the potential impact on the employee's family. I propose that employees who choose to switch employers are prone to bear risk than employees who do not change employers.

Theoretical models of job search in labor economics recognize the importance of risk aversion in job changes. Incorporating risk aversion into a model of job search, Harris and Weiss (1984) show that when wages are downward rigid, firms provide risk-averse workers wage insurance, which never declines but will increase when necessary to prevent the worker from moving to another firm. This wage insurance gives workers an incentive to delegate the job turnover decision to their employers, which suggests that they will not leave their jobs unless their employers fire them. Pissarides (1974) shows that more risk-averse workers accept lower wages than equally productive but less risk-averse workers. Thus, one would expect more riskaverse workers to be more likely to stay with the same employer than less risk-averse workers. Consistent with this argument, Pissarides (1976) and Vesterlund (1997) show that more risk- 
averse employees search less for other jobs, accept lower quality worker-firm matches, and are less likely to participate in the labor market.

Job turnover theories suggest that employees with different employment histories differ in their levels of firm-specific human capital investments (Becker 1962, and Jovanovic 1979b) and firm-employee match qualities (Jovanovic, 1979a and Mortensen, 1978). Both differences in specific human capital investments and firm-employee match qualities affect an employee's risk preference. CEOs that spend most of their business careers in one firm make more firm-specific human capital investments than CEOs who change employers more frequently. Because specific human capital investments would be lost if the firm fails, a CEO with more firm-specific human capital investments will be more risk averse than a CEO with lower firm-specific human capital investments. CEOs with more employer changes and more diversified firm or industry experience have lower levels of first-specific human capital investment and therefore, be less risk averse. Job matching theories (e.g., Jovanovic, 1979a and Mortensen, 1978) suggest that employees who match well with their firms are unlikely to change employers. CEOs with fewer employer changes are likely to be the ones that match well with their firms. Prospect theory (e.g. Kahneman and Tversky, 1979) predicts that individuals are more risk averse toward positive outcomes than toward negative outcomes. Thus, CEOs that match well with their firms should be averse to lose the right matches (positive outcomes) and become more risk averse in decision making.

Empirical evidence also lends support to the proposition that employment history can reveal a CEO's risk-taking traits. Organizational behavior studies (e.g., Nicholson and West, 1988 and Nicholson et al. 2005) use the number of job changes as an indicator of willingness to engage in risky behavior. Nicholson et al. (2005) provide empirical evidence that people with higher 
frequencies of career and employer changes have higher risk propensities. Using a longitudinal survey of private households and persons in Germany, Pfeifer (2008) finds that the number of employer changes relates positively and significantly to individual's risk-taking behaviors.

In summary, both theory and empirical evidence support the idea that employees with greater propensities to bear risk change employers more frequently and have more diversified firm and industry experience.

\subsection{CEO-firm Match}

As a first step in understanding the relation between the CEO's employment history and risktaking in firm policies, I examine why a firm hires a CEO that have changed employers multiple times. Optimally, firms prefer to hire CEOs whose skill sets match with firm needs. Based on the conceptual development in the previous section, I expect the level of firm risk prior to the CEO turnover and the importance of firm-specific knowledge to influence a firm's decision to hire a mobile CEO. In addition to these two factors, I also control for prior firm performance, industry conditions, board structure and the prior CEO's characteristics in the CEO-firm match analysis.

I expect the firm's risk level prior to the CEO turnover to influence the firm's decision to hire a mobile CEO. A firm in which taking risk is more important would prefer to hire a $\mathrm{CEO}$ who is less risk averse to better align incentives. For example, young firms or firms in a high-growth industry would need a CEO that is more risk-taking (Graham et al., 2008). Thus, I expect these firms to prefer mobile CEOs. Additionally, the lifecycle of the firm can influence the optimal CEO-firm match. If a firm has reached a mature stage, it would arguably require less risky policies than in its high-growth stage and prefer to hire a CEO with a lower propensity to implement riskier policies. This argument implies that firms with high pre-turnover risk are less likely to hire a mobile CEO. Though both situations are likely to exist, which one dominates is 
an empirical question. In addition, firms, that are riskier (more conservative) than other firms in the same industry, might prefer to hire a less (more) risk-taking CEO to reduce firm risk. Therefore, I expect firms to prefer mobile CEOs when their firms' pre-turnover risk is lower than the average risk level in the industry.

Firms with high requirements for firm-specific knowledge are more likely to hire CEOs who are less mobile and have worked a long time in their firms. I use firm age, size, industry homogeneity, and the ratio of $R \& D$ to total assets ( $R \& D$ intensity) to proxy for the importance of firm-specific knowledge. Older and larger firms have more established corporate culture, complex internal social networks and operational processes. Thus, I expect older and larger firms to require more firm-specific knowledge than younger and smaller firms. In homogenous industries, the manager's human capital is more likely to be transferable among firms (Parrino, 1997), which reduces the importance of firm specific human capital in these industries. Therefore, I expect firms in homogeneous industries to prefer mobile CEOs. Firms with high R\&D intensity may require their employees to make more firm-specific investments than firms with low R\&D intensity (e.g., Titman and Wessels, 1988 and Kale and Shahrur, 2007).

A firm's need to change its prior policies can also affect the decision to hire a mobile CEO. Evidence suggests that CEOs learn from their work experiences (Hambrick, 2007). I argue that since a mobile CEO has experienced different corporate policies and environments, she is more capable of dealing with uncertainty and can selectively adapt the strengths of her prior firms to the current firm. Hence, I expect firms with poor prior performance or that have experienced negative industry or firm shocks, and therefore have a need to change policies, to hire a mobile CEO. A forced turnover suggests a mismatch between the prior CEO and the firm (Allgood and 
Farrell, 2003). As a result, I expect firms that dismiss their prior CEOs to prefer mobile CEOs, who are more likely to change the policies of the previous CEO.

Weisbach (1988) finds that insiders are appointed to the board before a CEO turnover and resign from the board after the CEO turnover. Raheja (2005) suggests that firms in which information asymmetry is high will optimally have more insiders on the board. Together, these articles suggest that firms that appoint more insiders to the board before a CEO turnover are likely to be the firms where information asymmetry is high and insider succession is optimal. Because mobile CEOs are less likely to be insiders and possess lower firm-specific knowledge, I expect firms that have larger boards and more insiders in their boards prior to CEO turnover to prefer CEOs that do not change employers frequently and have more firm-specific knowledge.

I also expect the prior CEO's tenure and chairman status to influence a firm's decision to hire a mobile CEO. Prior CEOs with long tenure and chairman status are more likely to be CEOs whose policies have been successful (e.g., Vancil, 1987). Firms with successful prior CEOs are more likely to groom a CEO that can continue the "status quo" of the firm. Managers who spend a longtime working with the prior CEO are better candidates for this purpose. Moreover, based on assumptions that boards optimally choose CEOs to match with firm characteristics and firm characteristics persist for a long time, the new CEO is likely to possess a managing style that is similar to that of the prior CEO. Long-tenured prior CEOs are less likely to be mobile CEOs, ceteris paribus. Thus, the prior CEO's long tenure can also signal the firm's need for firmspecific knowledge. In sum, I expect that firms where prior CEOs have long tenure and are also the chairman of the board are less likely to hire mobile CEOs. 


\subsection{CEO Employment History and Risk-taking in Firm Policies}

If mobile CEOs have a higher propensity to bear risk than less mobile CEOs, as discussed in section 2.1, one would expect mobile CEOs to implement riskier firm policies. Below, I develop hypotheses for the influence of a CEO's employment history on his firm's financing and investment policies.

A risk-averse $\mathrm{CEO}$ has incentives to implement financing policies that involve lower levels of debt in the firm's capital structure. First, the higher level of debt in a firm's capital structure increases the possibility that the firm experiences financial distress. CEOs bear significant personal costs in the event of financial distress (e.g., Gilson, 1989 and 1990, and Gilson and Vetsuypens, 1993). Second, a higher level of debt increases stock volatility which in general reduces the CEO's certainty equivalent of wealth (Lewellen, 2006). The extent to which these volatility costs reduce CEO utility relates positively to the degree of a CEO's risk aversion. Therefore, more risk-averse CEOs are likely to use less debt. Combining both career and firm volatility concerns, I expect mobile CEOs to be less risk averse and take on more debt.

A CEO's risk-aversion level can affect the riskiness of his investment policies. Evidence suggests that investments in intangible assets are riskier than investments in tangible assets (Ryan and Wiggins, 2002; Coles et al., 2006). Moreover, Kothari, Laguerre, and Leone (2002) and Amir, Guan, and Livne (2007) find that investments in R\&D expenditures and advertising contribute to earnings variability more than capital expenditures. Thus, I examine the influence of CEO employment history on the firm's investment in intangible assets (R\&D and advertising expenditures) and tangible assets (capital expenditures). I expect mobile CEOs to increase investment in advertising and decrease capital expenditure, ceteris paribus. For R\&D, however, the propensity of a mobile CEO to bear risk can be offset by the increased importance of firm- 
specific knowledge associated with high R\&D intensity. Mobile CEOs possess lower firmspecific knowledge and would be less likely to invest in R\&D when firm-specific knowledge is important in managing these investments. Because the firm-specific knowledge is less important in homogeneous industries (Parrino, 1997), I expect mobile CEOs to increase R\&D investment in homogenous industries and decrease $\mathrm{R} \& \mathrm{D}$ in heterogeneous industries

As a result of higher financial leverage and riskier investment policies, I expect mobile CEOs to increase firm risk. Because changes in financing and investment policies may affect both the firm's systematic and idiosyncratic risk, I also examine whether mobile CEOs increase more systematic risk, or idiosyncratic risk or both.

\subsection{CEO Employment History, Market Reactions, and Long-run Performance}

If mobile CEOs implement riskier firm policies, it stands to reason that shareholders would react differently to appointments of CEOs with different employment histories. One source of shareholder-manager conflicts is that shareholders and managers have different attitudes toward risk (e.g., Fama 1980). Although shareholders can diversify firm-specific risk by holding a portfolio of firms, the manager's future income and career depends on what happens in the firm. Furthermore, a manager's human capital is inalienable and difficult to diversify. The manager, therefore, will be averse to implement risky policies. This conflict between shareholders and the manager is mitigated when the manager is less risk-averse. If mobile CEOs are less risk-averse, one would expect shareholders to react positively to the appointment of a mobile CEO, ceteris paribus.

On the other hand, bondholders receive fixed periodic interest payments from the firm and are averse to risky firm policies. As a result, I expect bondholders to react negatively to the 
appointment of a mobile CEO. The equity claim in a levered firm is like holding an European call option on the firm's assets (e.g., Myers, 1977, and Galai and Masulis, 1976). The value of this call option is an increasing function of the volatility of the firm's future cash flows. Thus, shareholders prefer riskier firm policies at the expense of bondholders. Empirical evidence, for example, Defusco, Johnson and Zorn (1990) supports this argument. As proposed in the previous section, mobile CEOs are likely to implement riskier firm policies and increase firm risk. In anticipation of risk-shifting from shareholders to bondholders, bondholders would require a higher return and increase the firm's cost of debt after the firm hires a mobile CEO.

If the board optimally hires the CEO for the firm, idiosyncratic managing styles will not lead to inefficiency in firm performance. Thus, if CEOs are matched to firms that need their specific styles, one would not expect mobile CEOs to perform differently than other CEOs. On the other hand, differences in the quality of corporate governance and frictions in the CEO labor market can lead to suboptimal matches between CEOs and firms. In this case, idiosyncratic managing styles can cause firms to implement suboptimal policies and CEO employment history would relate to firm performance. To draw inferences on the efficiency of firm-CEO matches, I examine if CEO employment history affect subsequent firm performance after the CEO turnover.

\section{Data, Variable Construction and Summary Statistics}

\subsection{Sample and Data Sources}

To obtain a sample, I start with the CEOs of all firms in the S\&P 1,500 as of January 2005. From the original 1,500 CEOs, I exclude 210 CEOs of financial firms (SIC codes $6000-6999$ ) and 91 CEOs of utilities firms (SIC codes 4900 - 4999). I also exclude 55 CEOs with missing data in Compustat. The final CEO sample consists of 1,144 CEOs. I collect information on a 
CEO's employment history and education from proxy statements, Marquis Who's Who in Finance and Business, Forbes.com, Hoovers.com, Reuters.com, corporate web sites, and the CEO profiles published by Spencer Stuart. I cross check data from different sources to make sure the information is consistent and accurate. For every CEO, I collect the CEO turnover date, announcement date and turnover reason from newswire reports on LexisNexis.

I obtain firm financial, accounting, and bond rating data from the Standard and Poor's Compustat database from a year before the year of CEO turnover to 2007. To be included in the sample, I require firms to have information on total assets, sales, number of shares outstanding and stock price at the end of the fiscal year. The data used to compute CEO compensation variables are from the Execucomp database. From the sample of 1,144 CEOs, I exclude 203 CEOs that became CEO before their firms went public or in the year of their firms' IPOs, 16 CEOs that became CEO before 1992 (the year ExecuComp starts), and 8 CEOs whose firms have negative book equity. The final sample for firm policy and risk analysis includes 917 CEOs and 5,139 firm years from 1992 to 2007.

Information on institutional blockholders comes from the CDA Spectrum database of SEC 13-f filings. The stock return data is from the Center for Research on Security Prices (CRSP) database. The bond data is from Mergent's Fixed Incomes Security Database (FISD) and the yields on Treasury securities are from H15 release of the Federal Reserve Bank of New York. I collect the size of board, the number of board insiders, prior CEO's chairman status from 1995 to 2002 from firms' annual proxy statements. Information for these governance variables after 2002 is from Corporate Library. From proxy statements, I also collect information on whether the CEO is a member of the founding family. 


\subsection{CEO characteristics and summary statistics}

\subsubsection{Variables for CEO employment history}

I construct five proxies to measure different dimensions of a CEO's employment history and propose that these proxies will relate to the riskiness of the CEO's policies. The first two proxies relate to the number of employer changes, the third one captures the recency of employer changes, and the fourth and fifth proxies are designed to measure the degree of diversification for a CEO's firm or industry experience.

Variable One: The number of employers the CEO has worked for (\# Employers)

I measure a CEO's \#Employers as the number of employers the CEO has worked for throughout his career, starting from his first full-time job and excluding military assignments. I do not count mergers and spinoffs as additional employer changes, because these employer changes are not initiated by employees and do not reflect employees' risk-taking preferences. If one of the CEO's prior firms was acquired by another firm and the CEO continues to work for the acquirer, I count the acquired firm and the acquirer as one firm. If one of the CEO's prior firms is a spin-off from another firm and the CEO works for the spin-off firm, then I count the spin-off firm and the parent firm as one firm. I cannot rule out the possibility that some of employer changes are forced. Since CEOs are highly successful employees, however, it is unlikely that any CEO would incur multiple dismissals. To the extent that a CEO's employment history might include some forced job turnovers that do not reflect risk aversion, my employment history measures bias against finding relations between CEO employment history and the riskiness of the firm's policies. 
Variable Two: The number of employers per year (\#Employers per year)

To control for differences in career lengths, I compute \#Employers per year as the total number of employers divided by the CEO's career length:

$$
\text { \#Employers per year }=\frac{\# \text { Employers }}{\text { CEOTotalCareerLength }} \text {. }
$$

The variable, CEOTotalCareerLength, is the number of years the CEO has worked since his first full-time job. The number of employers per year, to some degree, captures the likelihood of changing employers in a given year.

Variable Three: The recency of employer changes (Employer Change Recency)

Some CEOs change employers more at the beginning of their careers and some other CEOs change employers more recently. To account for the possibility that more recent changes are more relevant than distant changes, for each $\mathrm{CEO}$ and sample year, I construct a variable to capture the recency of a CEO's employer change:

$$
\text { Employer Change Recency } \left.=\sum_{i=1}^{n} \frac{\text { CEOTotalCareerLength }-(\text { Year }- \text { FirstYear }}{i}\right)
$$

The variable CEOTotalCareerLength is the number of years the CEO has worked since his first full-time job. FirstYear ${ }_{i}$ is the year in which the CEO starts work for firm i. Year is the year of the observation. Year-FirstYear ${ }_{i}$ measures the number of years from the year in which the $\mathrm{CEO}$ changes employer to firm $\mathrm{i}$ to the year of observation. For example, $\mathrm{CEO}_{\mathrm{A}}$ and $\mathrm{CEO}_{\mathrm{B}}$ both have worked for two employers. But $\mathrm{CEO}_{\mathrm{A}}$ changed her employer in 1988 and $\mathrm{CEO}_{\mathrm{B}}$ changed her employer in 1998. Assuming both of them started working for their first firms in 1983, their Employer Change Recency in year 2005 would be: 


$$
\begin{aligned}
& \mathrm{CEO}_{\mathrm{A}}=\frac{22-(2005-1988)}{22}+\frac{22-(2005-1983)}{22}=\frac{5}{22}+0=0.227 \\
& \mathrm{CEO}_{\mathrm{B}}=\frac{22-(2005-1998)}{22}+\frac{22-(2005-1983)}{22}=\frac{15}{22}+0=0.682
\end{aligned}
$$

The variable has a higher value for CEOs that change employers more recently than CEOs that change employers at the beginning of their careers. If the CEO has only worked for one employer throughout his career, his Employer Change Recency would be zero.

A CEO who changes employers frequently at the beginning of his career and remains in the same firm for a long time has a different employment history than a CEO who changes employer frequently throughout his career. Moreover, a CEO who changes employers across industries has different industry experience than a CEO who changes employers in the same industry. To measure these differences in the diversification level of a CEO's firm or industry experience, I construct two variables based on time durations the CEO spends with different firms or industries. Similar to the computation of a Herfindahl Index, I measure a CEO's firm (industry) experience diversification as follows:

Variable Four: CEO Firm Experience Diversification

CEO firm diversification $=\sum_{i=1}^{n}\left(\frac{F Y_{i}}{\sum_{i=1}^{n} F Y_{i}}\right)^{2}$

The variable $\mathrm{FY}_{\mathrm{i}}$ is the number of years the $\mathrm{CEO}$ worked for employer $\mathrm{i}$ and $\mathrm{n}$ is the number of employers for which the CEO has worked.

Variable Five: CEO Industry Experience Diversification

$\mathrm{CEO}$ industry diversification $=\sum_{i=1}^{n}\left(\frac{I Y_{i}}{\sum_{i=1}^{n} I Y_{i}}\right)^{2}$ 
Where $I Y_{i}$ is the number of years the CEO worked in industry $i$ and $n$ is the number of industries for which the CEO has worked.

CEOs with low values for these two diversification variables have more diversified experience and CEOs with high values for these two diversification variables have more focused firm or industry experience.

The 1,144 CEOs in my sample have worked in a total of 2,704 firms. Out of these 2,704 firms, 1,030 cannot be found in the Compustat database. For firms that cannot be found in the Compustat database, I search the Internet for the company's SIC code information. In most cases, I can find a firm's SIC code from the following three websites: www.answer.com, www.siccodes.us and www.manta.com. I check the company's website to make sure the SIC code found from the internet matches the company's main business. If I cannot find a firm's SIC code, I assign the firm a SIC code based on the main business of the firm. For example, if the firm is described as a supermarket chain, then I classify it as 5411, which is the SIC code for grocery stores. I am not able to assign SIC codes for 130 firms, because they were either self-run small business or were described as "some company" in the CEO's biography. In my study, I treat these companies as in different industries than the CEO's current firm. Results are robust if I drop these 130 firms or treat them as the same industry of the CEO's current firm. After I identify the SIC codes of each firm, I classify all the firms into 48 industries described in Fama and French (1997). I compute how long a CEO has worked in each industry by adding the number of years they have worked for different firms in the same industry.

\subsubsection{Other CEO Characteristics}

I include several variables to control for other CEO characteristics that might influence the riskiness of a CEO's policies. Bertrand and Schoar (2003) and Graham et al. (2008) find that 
whether the $\mathrm{CEO}$ has an MBA degree relates to firm policies. Therefore, I include a dummy variable that equals one if the CEO has an MBA degree. Hambrick (2007) documents that a CEO's functional areas can influence firm policies. To control for a CEO's functional area experience, I include a variable, \#Functional Areas, to indicate how many functional areas the CEO has worked in. Since CEOs with a finance background are likely to better understand risk, I include a Finance dummy to indicate whether the CEO worked in the finance area. This dummy equals one if the $\mathrm{CEO}$ had positions as financial analyst, CFO, treasurer, controller or investment banker.

To control for the possibility that founder CEOs and CEOs from the founder's family behave differently than other CEOs, I include a Founder dummy that equals one if the CEO is the founder or a family member of the founder. Adams, Almeida, and Ferreira (2005) find that powerful CEOs increase firm performance variability. To control for CEO power, I include CEO tenure, the number of years the CEO has been CEO in the current firm, as an additional control variable. Graham et al. (2007) find that younger CEOs are more prone to bear risk than older CEOs. I include CEO age in my regressions to control for the age effect.

\subsubsection{Summary Statistics for CEO Employment History and Characteristics}

Table 1 presents summary statistics for the five CEO Employment History variables. As of 2005, for the 1,144 CEOs in my sample, the average (median) number of employers for which a CEO has worked is 3.23 (3) employers. One hundred and eight nine CEOs (16.52\%) have worked for only one employer and 254 CEOs (22.20\%) have worked for at least five employers. The CEO who has worked for the maximum number of employers (11 employers) is Andrew Gatto, the CEO of Russ Berrie and Company Inc. 
The mean \#Employers per year is 0.106 , which suggests an average of one employer change in every 10 years. The CEO of Maverick Tube Corporation, C. Robert Bunch, has the highest value for \# Employers per year. In his 26-year career, he has worked for ten companies, which results in one employer change every 2.6 years. The mean (median) for Employer Change Recency is 1.129 (0.833). If the CEO has never changed employers, the recency variable is zero.

CEOs with higher (lower) values for the two experience diversification variables have more specific (general) firm or industry experience. As of 2005, the average (median) diversification levels for a CEO's firm experience is $0.555(0.506)$ and for a CEO's industry experience is 0.708 (0.702). If a CEO has worked in only one industry or one firm, his industry or firm experience diversification variables will have a value of one.

Table 1 also presents the descriptive statistics for other CEO characteristics. About 36\% CEOs in my sample have an MBA degree. About $22.9 \%$ CEOs in the sample have experience in the finance area. The average (median) CEO age is 55.6 (56) years. The average CEO tenure is 7.7 years and the median is 5 years. Two hundred and thirteen (18.62\%) CEOs in my sample are either the founder or from the founding family. Results are robust if I exclude these 213 CEOs from the sample.

\subsubsection{Differences in CEO Characteristics, Industry and Time Panel Distribution for CEOs with Different Employment Histories}

To examine differences in $\mathrm{CEO}$ characteristics for CEOs with different employment histories, I first classify the 1,144 CEOs into four groups based on the quartiles of \#Employers. The first group has CEOs who have worked for only one employer, the second group has CEOs who have worked for two employers, the third group includes CEOs who have worked for three 
or four employers, and the fourth group has CEOs who have worked for at least five employers. In Panel B of Table 1, I compare how CEO characteristics differ for CEOs in the first and the fourth groups.

CEOs who have worked for at least five employers have experience in more functional areas than CEOs who have worked for only one employer. The percentage of founding family members is much higher in the first group of CEOs that have worked for only one employer. CEOs that have worked for at least five employers are more likely to have an MBA degree and experience in the finance area. These CEOs also have shorter tenure. These findings are all statistically significant based on t-test for means and the nonparametric signed rank tests for medians. I find no difference in CEO age between these two groups.

I next examine whether CEO Employment History differ across industries and time panels. Figure 1 (a) shows industry distributions of CEOs that have worked for only one employer and CEOs that has worked for at least five employers. The p-value obtained by performing a ChiSquare test for the difference in these two distribution is 0.263 , suggesting that these two distributions are not statistically different. However, Figure 1 (a) shows some noticeable differences in manufacturing and service industries. Fifty percent of the firms that hire a CEO who has only worked for one firm are in the manufacturing industries and about $37 \%$ of the firms that hire a CEO that has worked for at least five employers are in the manufacturing industries. Although only about $7.5 \%$ of the firms that hire a CEO that has worked for one firm are in service industry, twenty-one percent of the firms that hire a CEO that has worked for at least five employers are in service industries. Figure 1 (b) presents how CEOs with different employment histories are distributed within an industry. Firms in communication, trade, service, technology, and transportation industries hire more CEOs who have worked for at least five 
employers. Firms in construction and manufacturing industries hire more CEOs who have never changed employers.

I present the distribution of $\mathrm{CEO}$ employment histories across different time panels in Figure 2. Figure 2 (a) shows the time panel distributions of CEOs who have worked for only one employer and CEOs who have worked for at least five employers. For firms that hire CEOs that have worked in only one firm, $8.28 \%$ are in the time panel before $1990 \mathrm{~s}, 35.5 \%$ are in $1990 \mathrm{~s}$, and $56.21 \%$ are in $2000 \mathrm{~s}$. For firms that hire CEOs that have worked for at least five employers, $3.37 \%$ are in the time panel of $1990 \mathrm{~s}, 30.29 \%$ are in $1990 \mathrm{~s}$, and $66.35 \%$ are in $2000 \mathrm{~s}$. The pvalue obtained by performing a Chi-Square test for the difference in these two distribution is 0.199 , suggesting that these two distributions are not statistically different. Figure 2 (b) presents how CEOs with different employment histories distribute within a time panel. In the time panel before 1990s, firms hire more CEOs that have worked for only one firm. In 1990s, firms' choices between these two groups are more balanced. About 20\% hire CEOs have worked for only one employer and about $21 \%$ hire CEOs that have worked for at least five employers. In the time panel of 2000s, firms hire more CEOs that have worked for at least five employers. Results from Figure 1 and 2 suggest that mobile CEOs are more preferable in certain industries and more mobile CEOs are hired in recent years.

\section{CEO Employment History and the CEO-firm Match}

To properly examine how a mobile CEO changes firm polices, I first study why a firm would hire a mobile CEO. Firms seek certain types of CEOs to match firm needs. At the same time, CEOs seek to work for certain type of firms to match their personal attributes. The observed CEO-firm matches are results of this mutual selection. Using survey data, Graham et al. (2008) 
find that firms with high historical and future growth rates are more likely to be run by riskloving CEOs. Thus, the risk of the firm and the risk tolerance of the CEO appear to be important to achieving a good CEO-firm match. In this section, I analyze how CEOs with different employment histories are matched to firms with different policies.

To understand what factors may influence a firm's decision to hire a mobile CEO, I focus on firm policies in the year before the CEO turnover. In section 4.1, I discuss the construction of variables that potentially impact the firm's CEO hiring decision and present summary statistics for these variables measured in the year prior to the year of CEO turnover. Then I study how preturnover firm policies differ based on the new CEO's employment history using both univariate (section 4.2) and multivariate analysis (section 4.3).

4.1 Summary Statistics for firm policies in the year before CEO turnover

As discussed in the hypothesis section, I expect the level of firm risk prior to the CEO turnover (pre-turnover firm risk), the importance of firm-specific knowledge, prior firm performance, industry conditions, board structure and some prior CEO's characteristics to influence a firm's decision to hire a mobile CEO. In the following paragraph, I briefly discuss the proxies for these factors.

I measure a firm's pre-turnover Total Firm Risk as the annualized standard deviation of daily stock returns in the year before CEO turnover. I use firm age, size and R\&D intensity to proxy for the importance of firm-specific knowledge. ${ }^{4}$ Prior performance variables include industrymedian-adjusted operating return on assets and annual stock return. Operating return on assets is measured as the ratio of operating income before depreciation and amortization divided by total

\footnotetext{
${ }^{4}$ I also include industry homogeneity as an additional variable to proxy for the importance of the firm-specific knowledge for a subsample of firms with industry homogeneity information. The CEO-firm match results for this subsample are included in Appendix B.
} 
assets. To control for industry shocks, I construct a negative (positive) industry shock dummy that equals one if total sales in the industry decreases (increases) $10 \%$ or more in the year prior to CEO turnover. ${ }^{5}$ I classify a firm as having a positive (negative) firm shock if the firm's sales growth is more (less) than $10 \%$ of the industry's median sales growth. Board size is the total number of board directors in the firm and Board Insider Ratio is the percentage of insiders in the board. I define insiders as board members who are current or former employees of the firm, or family members of current employees of the firm. Prior CEOs' tenures are from the Execucomp database or from the firm's proxy statement if missing in the ExecuComp database. From proxy statements, I also collect whether the prior CEO is the chairman of the board. I follow Parrino (1997) and classify a turnover as forced when news stories indicate that the CEO has been ousted, there were conflicts between the CEO and the board, the CEO resigned following poor performance, the CEO resigned or retired following an SEC investigation or class action lawsuit, or the CEO resigns without an outside job appointment within six months and the CEO is below the age of 60 .

Out of the 917 CEOs with data for firm financial variables, I exclude 139 CEOs whose prior CEOs' compensation data are not available in ExecuComp. Due to missing stock price information, I cannot compute prior leverage for 47 CEOs. I also exclude 13 CEOs whose firm's daily stock return data in the year prior to CEO turnover are not available for a minimum of 30 days. I collect information on board size, CEO/Chairman dual status, the percentage of insiders from firms' proxy statements. For the remaining 718 firms, four of them have no proxy

\footnotetext{
${ }^{5}$ Results on shocks are similar, if (1) I specify industry shocks based on industry median market to book ratio; (2) I set industry; (2) I set the negative (positive) industry shock dummy to one if total sales in the industry decreases (increases) $20 \%$ or more in the year prior to CEO turnover; (3) I classify a firm as having a positive (negative) firm shock if the firm's sales growth is more (less) than $20 \%$ of the industry's median sales growth.
} 
statement available in the year before the respective CEO turnover. As a result, the final sample for the CEO-firm match analysis includes 714 firms (CEOs).

Table 2 presents summary statistics for firm policies measured in the year prior to the respective CEO turnover year. These $714 \mathrm{CEOs} \mathrm{have} \mathrm{an} \mathrm{average} \mathrm{tenure} \mathrm{of} 8.9$ years ( 7 for median). Ninety-seven firms dismissed their prior CEOs (13.59\%). The CEO with the longest tenure is Charles Kaman. He has been the CEO of Kaman Corporation for 50 years. About $75 \%$ prior CEOs were also chairman of their boards. The average (median) board size is 9.5 (9). The largest board is the board of Verizon Communications Inc., which has 26 directors. About 37\% of the sample firms experience a positive industry shock and $7.14 \%$ experience a negative industry shock in the year prior to the year of CEO turnover. About $20 \%(22.13 \%)$ of the firms increase (decrease) their sales $10 \%$ or more than the corresponding industry medians.

\subsection{Univariate Comparison of Pre-turnover Firm Policies}

To examine differences in pre-turnover firm policies for CEOs with different employment histories, I classify the 714 CEOs into four groups based on the quartiles of the corresponding CEO employment history measure. I present means and medians for each quartile and compare differences in means and medians for firms in the bottom and the top quartiles. Table 3 presents results for \#Employers. Table B.3.1 of Appendix B includes results for the other four CEO employment history variables. For \#Employers, the first group has CEOs who have worked for one employer, and the fourth group has CEOs who have worked for at least five employers. I use t-test (nonparametric signed rank test) to test whether differences in means (medians) are statistically significant. In firms that are going to hire a CEO that has worked for multiple employers, their prior CEOs have shorter tenures and are less likely to be the chairman of the board. Firms that are going to hire a mobile CEO have smaller boards and fewer insiders prior to 
the CEO turnover. These firms are younger and smaller and have higher pre-turnover firm risk for all firm risk measures. I find that the firm is more likely to hire a mobile CEO when the firm dismisses the prior CEO, has poor prior performance, experienced a negative firm shock in the year prior to the year of CEO turnover. These findings are consistent with the premise that firms that need to change their prior policies are more likely to hire a CEO that has worked for multiple firms.

Results are similar when Q1 to Q4 groups are based on the other four CEO employment history variables. Taken together, results from univariate comparison support my argument that the importance of firm-specific knowledge, the board structure, pre-turnover firm risk, prior CEO characteristics, and the firm's need to change its prior policies relate to the firm's decision to hire a mobile CEO.

\subsection{Multivariate analysis of the CEO -firm Match}

Table 4 provides multivariate results on how CEOs with different employment history are matched to different firms. The five CEO employment history measures are the dependent variables. Independent variables include pre-turnover firm risk, firm size, firm age, R\&D intensity, prior $\mathrm{CEO}$ and current $\mathrm{CEO}$ characteristics, turnover types and industry or firm shocks. I also include the following firm control variables in the CEO-firm regression analysis: financial leverage, Tobin's Q, CEO cash compensation, CEO compensation delta, CEO compensation vega, industry concentration, activist institutional ownership, whether directors receive equitybased compensation. Appendix A discusses variable constructions for these variables and Table 2 presents summary statistics for these variables. 
In Table 4, the coefficients on Total Risk are positively and statistically significant at $1 \%$ when the dependent variables are \#Employers, \#Employers per year, and Employer Change Recency. This finding suggests that firms that have higher risk prior to CEO turnover prefer to hire CEOs that change employers more frequently. ${ }^{6}$ However, the coefficients on Total Risk are not statistically significant when the dependent variables are the diversification levels of CEO experience. Larger and older firms choose CEOs with fewer employer changes and more specific firm (industry) experience. This finding is consistent with the argument that larger and older firms require more firm-specific knowledge. High-R\&D-intensity firms require more firmspecific investments from their employees. Thus, they are more likely to choose CEOs who move less. Consistent with this argument, I find R\&D intensity relates negatively to the New CEO's \#Employers, \#Employers per year, and Employer Change Recency. R\&D-intensive firms are also less likely to hire a CEO with diversified firm experience. The diversification of the CEO's industry experience, however, does not relate to the firm's R\&D intensity. This result suggests that $R \& D$ intensity matters more for firms that need firm-specific knowledge than for firms that need industry-specific knowledge. Firms with larger boards hire CEOs that change employer less frequently and have more focused experience. When firm-specific knowledge is more important, the firm would optimally appoint more insiders as board directors (e.g., Raheja, 2005). Therefore, firms with a higher percentage of insiders in the board might require more firm-specific knowledge. Consistent with this argument, I find that boards with more insiders prefer CEOs that change employers less frequently and have more focused experience.

\footnotetext{
${ }^{6}$ In untabulated results, I also include an additional dummy variable that equals one when the firm's prior Total Risk is above the industry median. The coefficient on this variable is negative, but not statistically significant with a pvalue of 0.565 .
} 
Because mobile CEOs have more opportunities to deal with uncertainties, I expect that firms that need to change their prior policies are more likely to hire mobile CEOs. In support of this argument, I find that the coefficient on Negative Industry Shock dummy is negative and statistically significant at the $10 \%$ level when the dependent variable is the CEO's industry experience diversification. In untabulated results, I find no relation between CEO employment history and positive industry shocks. I also examine the relation between firm shocks and the CEO hiring decision. I find that firms that experience negative firm shocks prefer to hire CEOs that have worked for multiple employers and CEOs with more recent employer changes. However, the presence of negative firm shocks is not related to the diversification level of a CEO's professional experience. I find no relation between positive firm shocks and the CEO employment history.

Allgood and Farrell (2003) suggest that CEO dismissals signal mismatches between the CEO and the firm. The most common reason for a CEO to be dismissed is poor prior performance. Therefore, I would expect firms that fire their prior CEOs to hire a mobile CEO who is more likely to bring changes to the firm. Consistent with this argument, I find that firms that dismiss their prior CEOs are more likely to hire a CEO that has worked for multiple employers. The coefficients on prior industry adjusted operating and stock performance are negative. The coefficient on the industry-median-adjusted stock return is statistically significant for Employer Change Rencency. This results suggests when the prior stock performance is poor, the firm is more likely to hire a CEO that has more recent employer changes.

Results in Table 4 also provide evidence that prior CEOs' characteristics relate to the firm's decision to hire a mobile CEO. If the prior CEO has shorter tenure, the firm is more likely to hire a mobile CEO. One possible interpretation of this result is that the prior CEO has a shorter tenure 
because he/she was not successful. Therefore, the firm is looking for a mobile CEO to change the firm's prior policies. Another possible interpretation is that it is optimal for the firm to hire CEOs that are mobile. Therefore, both the prior CEO and the new CEO are mobile CEOs with shorter tenures.

The new CEO's education, age, founder status, and functional area experience also relate to the CEO's employment history. The coefficient on CEO age is positive when the dependent variable is \#Employers and negative when the dependent variable is \#Employers per year. As one would expect, this finding suggests that older CEOs are likely to have more employers over the span of their careers, but are less likely to move in a given year. CEOs with an MBA degree move more often and have less firm-specific experience. CEOs with finance backgrounds are more likely to move and have more diversified industry and firm experience. Founders have fewer employer changes and more focused experience.

In summary, regression results in Table 4 indicate that different firms choose CEOs with different employment histories. Firms hire CEOs who change employers more frequently and have more diversified experience when the firm's prior risk is high, firm-specific human capital is less important, the board is smaller and has fewer insiders, the prior CEO is dismissed and has shorter tenure. In the presence of a negative industry shock, firms prefer CEOs with diversified industry experience.

\section{CEO Employment History and Firm Policies}

In this section, I examine the relation between the CEO's employment history and the risktaking in her policies. I discuss variable construction and summary statistics for firm policies in Section 5.1. Section 5.2 presents univariate comparison of firm policies for CEOs with different 
employment histories. I present the multivariate regression model and discuss the multivariate results in Section 5.3.

\subsection{Summary Statistics for Firm Policies after CEO Turnover}

I examine a CEO's risk-taking in the firm's financing and investment policies. For the firm's financing policy, I examine the firm's financial leverage. For the firm's investing policy, I examine the firm's investments in R\&D, Advertising and Capital Expenditures. I measure the firm's Financial Leverage as the book value of long-term debt plus debt in current liabilities divided by long-term debt plus debt in current liabilities plus the market value of equity. Results are robust to using a leverage ratio based on the book value of equity (Table B.1.3 of Appendix B). $R \& D$ Intensity is the ratio of $R \& D$ expenditures divided by total assets. I set $R \& D$ intensity to zero if the firm did not report $R \& D$ expenditures. Advertising intensity is the ratio of advertising expenses divided by total assets. Similar to R\&D intensity computation, I set advertising intensity to zero if the firm did not report advertising expense. Capital expenditure intensity, CAPEXP, is computed as capital expenditure divided by total assets. ${ }^{7}$

Financing and investment policies are different channels through which a CEO can influence the firm's risk. I construct three variables, Total Risk, Market Risk and Firm-specific Risk, to capture the overall riskiness of a firm's policies. I measure a firm's Total Risk as the standard deviation of daily returns multiplied by the square root of 254. I measure Firm-specific Risk in two ways. Firm-specific risk (CAPM) is the standard deviation of the residuals from a market model regression of daily returns on the CRSP value-weighted index multiplied by the square root of 254 trading days. Firm specific risk (FF+Momentum) is the annualized standard

\footnotetext{
${ }^{7}$ Results are robust to using net capital expenditures, which is computed as capital expenditure (Compustat item 128) less sales of property, plant and equipment (Compustat item 107) divided by total assets (Compustat item 6). I obtain similar results when scaling all three investment variables by total sales.
} 
deviation of the residuals from a regression of daily stock returns on the three Fama-French factors plus a momentum factor. ${ }^{8}$ A firm's Market Risk is the beta from the market model regression used to obtain firm-specific risk (CAPM). To compute these firm risk measures, I require a firm to have at least 30 days of returns for a fiscal year. This requirement reduces firmyears from 5,139 to 5,113 for firm risk measure related analysis.

Table 5 presents summary statistics for these firm policy variables. As discussed in Section 3, the sample for post-turnover firm policy analysis consists of 917 CEOs and 5,139 firm years ranges from 1992 to 2007 . The mean Leverage is 0.177 and the median is 0.138 . R\&D Intensity has a mean of 0.029 and a median of 0.002 . The mean (median) of advertising intensity is 0.013 (0). Capital Expenditure has a mean of 0.054 and a median of 0.039 . The mean (median) for Total Risk is 0.384 (0.346). The sample mean (median) for Firm-specific Risk (CAPM) is 0.343 (0.305), for Firm-specific Risk (Four-Factor) is 0.330 (0.293) and for Market Risk is 1.087 (1.019). Table 5 also presents summary statistics for CEO employment history variables and other CEO characteristics. Except for \#Employers, all other four employment history variables change for every sample year. Results are robust if I hold these four variables constant and use their values in the year of CEO turnover in the analysis (see Table B.1.6 of Appendix B). To minimize the influence of outliners, I winsorize all firm-level variables at the $1 \%$ and $99 \%$ levels.

\footnotetext{
${ }^{8}$ Results are robust if I use equally-weighted market index. All the factors are from WRDS' Fama-French Research Portfolios and Factors database. For constructions of these factors, refer to Kenneth French's web site at Dartmouth.
} 


\subsection{Univariate analysis of CEO Employment History and firm policies}

To examine the relation between CEO employment histories and the riskiness of firm policies, CEOs are classified into Q1 and Q4 groups based on whether they belong to the bottom or top quartiles of the corresponding CEO employment history measure. I present results of univariate comparison for \#Employers in Table 6. In Panel A of Table 6, CEOs who have worked for at least five employers have lower CAPEXP, higher R\&D, and higher total, firmspecific and market risk. Results are similar when the Q1 and Q4 groups are based on the quartiles of \#Employers per year or Employer Change Recency. When the groups are based on the quartiles of the diversification levels of a CEO's firm (industry) experience, CEOs with less diversified experience have less risky policies, such as higher capital expenditures, lower R\&D intensity, and lower firm risk.

To better understand how CEO employment histories influence firm policies, I compute industry-median adjusted changes in firm policies for each post-turnover firm year. If the firm's pre-turnover policy is already above the industry norm, one would expect the new CEO to be less likely to increase the level of firm policies regardless of the CEO type. To control for the level of the firm's pre-turnover policy, for each policy or risk measure, I divide the sample into two groups based on whether the firm policy in the year prior to CEO turnover is above or below industry median. Panel B (C) of Table 6 presents differences in changes in firm policies for CEOs that have worked for different numbers of employers when the respective firm policy is below (above) the sample median. When the firm's pre-turnover Leverage is below the industry median, changes in Leverage are positive for CEOs in all four quartiles. CEOs that have worked for at least five employers, however, increase Leverage more and the difference is statistically significant at the $5 \%$ for both the $t$-test and the nonparametric signed rank test. When the firm's 
pre-turnover policy or risk is below the industry median, CEOs that have worked for at least five employers also invest more in advertising and increase more firm-specific risk. These differences are statistically significant. Taken together, these findings are consistent with my hypothesis that CEOs who change employers more frequently implement riskier policies. In Panel C, when the firm's pre-turnover policy or risk is above the industry median, CEOs that have worked for at least five employers invest more in advertising, less in R\&D and Capital Expenditure. I find no difference in Leverage and firm risk when the prior leverage or risk is above the industry median.

5.3 Multivariate analysis of CEO Employment History and firm policies

\subsubsection{Model Specifications for the Multivariate Analysis}

To examine how CEO employment history affects firm policies, I estimate the following model for Leverage, Advertising Intensity, and Firm Risk variables:

Firm Policy $=b_{1} C E O$ Employment History Proxy $+b_{2}$ Pre-turnover Firm Policy $+b_{3}$ Firm Control

$$
\text { Variables }+b_{4} C E O \text { Control Variables }+ \text { Industry and Year Dummies }+e
$$

When dependent variables are Leverage and Advertising Intensity, Total Risk, Market Risk and Firm-specific Risk, I expect $b_{1}$ to be positive when CEO employment history is measured as \#Employers, \#Employers per year or Employer Change Recency and negative when CEO employment history is measured as the degree of diversification for the CEO's firm or industry experience. When the dependent variable is CAPEXP, I expect $b_{1}$ to be negative when CEO employment history is measured as \#Employers, \#Employers per year or Employer Change 
Recency and positive when CEO employment history is measured as the degree of diversification for the CEO's firm or industry experience. ${ }^{9}$

Because R\&D intensity can serve as a proxy for both the importance of firm-specific knowledge and the riskiness of firm policies, I expect mobile CEOs to increase R\&D intensity when the firm-specific knowledge is less important. Parrino (1997) suggests that skills are more transferable and the firm-specific knowledge is less important in homogeneous industries. I use industry homogeneity to measure the importance of firm-specific knowledge and include an interaction term of CEO employment history and Industry Homogeneity in the model for R\&D intensity:

$R \& D$ Intensity $=b_{1} C E O$ Emp. History Proxy $+b_{2}$ CEO Emp. History Proxy $*$ Industry Homogeneity + $b_{3}$ Industry Homogeneity $+b_{4}$ Pre-turnover Firm Policy $+b_{5}$ Firm Control Variables $+b_{6}$ CEO Control Variables + Industry Dummies + Year Dummies $+e$

I expect $\mathrm{b}_{2}$ to be positive when CEO employment history is measured as \#Employers, \#Employers per year or Employer Change Recency and negative when CEO employment history is measured as the degree of diversification for the CEO's firm or industry experience.

Control variables for firm characteristics include pre-turnover firm policies, firm size, Ln(firm age), profitability, CEO cash compensation, CEO compensation vega and delta, activist institutional ownership and whether directors receive equity-based compensation, Tobin's Q, and industry concentration. Appendix A includes variable constructions for these control variables and summary statistics for these control variables are presented in Table 5. Pre-turnover firm policy is the firm policy in the year before the year of CEO turnover. By regressing the post-

\footnotetext{
${ }^{9}$ I obtain similar results when the dependent variables are: (1) changes in firm policies, i.e., firm policies after the CEO turnover subtract firm polices in the year prior to the CEO turnover; or (2) industry median adjusted firm policies. The regression is based on an unbalanced panel dataset. However, results are also robust to using balanced subset panels of the dataset. These robustness results are included in Tables B.1.1 and B.1.2 of Appendix B.
} 
CEO-turnover policies on pre-turnover policies, I isolate the changes in firm policies after CEO turnover. Results are the same if I use changes in firm policies as dependent variables. Control variables for CEO characteristics include $\ln (\mathrm{CEO}$ Tenure +1$)$, $\ln (\mathrm{CEO}$ Age), MBA dummy, Founder dummy, and Finance Background dummy. Industry dummies based on 48 Fama and French Industries are included to control for other possible omitted industry fixed effects that are not captured by industry concentration. Year dummies are included in every regression. For statistical significance, I report $p$-values based on heteroskedasticity adjusted standard errors clustered by firm.

\subsubsection{Instrumental Variables for CEO Employment History}

The analysis in Section 4 suggests that it is necessary to control for the CEO-firm match endogeneity when I examine the relation between CEO employment history and firm policies. Therefore, I use the CEO-firm match regression presented in Table 4 as the first-stage of the instrumental variable 2SLS estimation to control for the CEO-firm match selectivity but using the sample period after CEO turnover. ${ }^{10}$

Based on the literature, I identify three instrumental variables for CEO employment history. Valid instruments should closely relate to a CEO's employment history, but not relate to the CEO's current firm policies through channels other than CEO employment history. Oyer (2006, 2008) suggests that the economic condition at the time of a person's job market and the person's initial job placement have long-run effects on the person's career path. Malmendier and Nagel (2007) find that an individual's experience of macro-economic shocks affects the individual's

\footnotetext{
${ }^{10}$ OLS results for firm policy analysis are included in Appendix B. Because board structure variables, board size, the percentage of insiders, $\mathrm{CEO} / \mathrm{Chairman}$ dual status, are only available for a subsample of firms, I report the results for this subsample in Appendix B. The regressions in the main text do not include these board structure variables.
} 
subsequent risk-taking in the long term. Based on Oyer and Malmendier and Nagel's work, the first instrumental variable I use is the unemployment rate at the year when the CEO started his first full-time job. The second instrumental variable is whether the CEO has non-business career before he took a position in a firm. Non-business careers include academic or government jobs. Although I expect these two instruments to impact a CEO's career path, I do not expect them to directly relate to the CEO's current firm polices. The third instrumental variable I use is the number of years a CEO has worked in his current firm's industry. How long a CEO has been working in his current firm's industry directly relate to the CEO's industry diversification level. CEOs that do not change industries also work for fewer employers, ceteris paribus. Therefore, I expect the number of years a CEO has worked in his current firm's industry to closely relate to the CEO's career path. However, one would not expect this variable to relate to firm policies through channels other than CEO employment history.

I formally test the validity of these three instruments using Hansen's J-test and a first-stage F-test. The null hypothesis of the first-stage F-test is that the instruments are jointly insignificant. The joint null hypothesis of Hansen's J-test is that the instruments are valid instruments, i.e., uncorrelated with the error term, and that the excluded instruments are correctly excluded from the estimated equation. Under the null hypothesis, the test statistic is distributed chi-squared in the number of over-identified restrictions. I present $p$-values for instrument validity tests at the bottom of each table for second-stage policy results.

Table 7 presents the first stage regression results for instrumental variables. I use contemporaneous financing variables to be consistent with the equation in the second stage. The coefficient on Unemployment Rate is negative with a $p$-value of 0.107 when the dependent variable is \#Employers. The coefficient on Unemployment Rate is positive and statistically 
significant at the $1 \%$ level when the dependent variable is \#Employers per year. This result implies that when the economic conditions are poor at the time the CEO first participates in the job market, he is more likely to change jobs in the future. If a CEO has non-business occupations before he takes a position in a firm, he tends to have more employers, more employers per year, less diversified firm and industry experience. Coefficients on the number of years working in the current firm's industry are negative when dependent variables are \#Employers, \#Employers per year and Employer Change Recency and are positive when dependent variables are diversification levels of the CEO's firm and industry experience. These results support the argument that CEOs who have worked in the same industry for a long time are less likely to work for multiple employers and have less diversified experience.

\subsubsection{CEO Employment History and Financing Policy}

Table 8 presents the 2SLS results for the debt policy. The dependent variable is Leverage. Based on the literature, for example, Mackay and Phillips (2005), and Rajan and Zingales (1995), I include profitability, capital intensity, and depreciation ratio as additional control variables for the debt regression. After including these additional variables and requiring the firm to have leverage information in the year prior to CEO turnover, the sample size for debt regression declines from 5,139 to 4,826 firm years. As shown at the bottom of Table 8, the $F$-stat for joint significance tests on the instrumental variables are well above 10 for all the models, suggesting that these instrumental variables are not weak. The Hansen's J-test has $p$-values range from 0.406 to 0.684 . These $p$-values fail to reject the null hypothesis that the three instrumental variables are valid. \#Employers and \#Employers per year are positively related to the debt ratio. Both relations are statistically significant at the 5\% level. Employer Change Recency relates positively to leverage and the coefficient is statistically significant at the $5 \%$ level. The 
coefficients on Firm (Industry) Experience Diversification are negative and statistically significant at the 5\% level. These results support my hypothesis that CEOs with more employer changes and more diversified experience increase financial leverage. Pre-turnover leverage relates positively to a firm's current leverage, which suggests that a firm's capital structure is persistent. The coefficients on control variables are consistent with prior studies. Firms that are larger, less profitable, have lower Tobin's Q, higher capital intensity, and lower R\&D expenditures have higher leverages. As in Bertrand and Schoar (2003) and Graham et al. (2008), firms that have CEOs with an MBA degree are related to firms with higher levels of debt. Taken together, results in Table 8 support my hypothesis that mobile CEOs increase financial leverage.

\subsubsection{CEO Employment History and Investment Policy}

In this section, I discuss the relation between CEO employment history and the firm's investment policies. As in Coles et al. (2006), I include surplus cash and leverage as additional control variables for investment policy regressions. The inclusion of surplus cash as additional control variable reduces the sample size from 5,139 firm years to 5,074 firm years. Because budget constraints can limit total investments, I also include the other two investment policies which are not the dependent variable as additional controls. For example, when R\&D intensity is the dependent variable, I add advertising intensity and capital expenditures as control variables. I present 2SLS results for capital expenditures, R\&D intensity, and advertising intensity in Table 9 through Table 11. The three instrumental variables for CEO employment history are the same as the ones described in Section 5.3.2. For brevity, I do not repeat first-stage results. However, results are similar to first-stage results reported for financial leverage (Table 7). First-stage joint significance tests and Hansen's J-tests indicate that these instrumental variables are valid for 
investment policy regressions. I report $p$-values for Hansen's J-test and $F$-stat for the first-stage joint significance tests at the bottom of Tables 9-11.

(1) CEO Employment History and Capital Expenditures

Table 9 presents 2SLS results for capital expenditures. The dependent variable is capital expenditures divided by total assets. The exclusion of firm years that do not have capital expenditures information in the year prior to CEO turnover reduces the sample size from 5,074 to 5,029. In support of my hypothesis that mobile CEOs invest less in tangible assets, the coefficients on \#Employers, \#Employers per year, and Employer Change Recency are negative and statistically significant at the $1 \%$ level. On the other hand, CEOs with more focused firm or industry experience invest more in capital expenditures than CEOs with more diversified experience. Both coefficients on firm and industry experience diversification are statistically significant at the $1 \%$ level. For CEO control variables, Older CEOs and CEOs with longer tenure invest less in capital expenditures. CEOs with a finance background also invest less in capital expenditures.

(2) CEO Employment History and R\&D Intensity

As discussed in Section 2, R\&D intensity can serve as a proxy for both the importance of firm-specific knowledge and the riskiness of firm policies. Mobile CEOs have lower firmspecific knowledge and are less likely to make $R \& D$ investments if it requires firm-specific knowledge to manage these investments. When the firm-specific knowledge is less important, mobile CEOs can increase firm risk by investing in R\&D. The relation between CEO employment history and the investment in $R \& D$ is an outcome of both effects. I use industry homogeneity to proxy for the importance of the firm-specific knowledge. I follow Parrino (1997) to construct industry homogeneity and require a minimum of 20 firms in a two-digit SIC code. 
This requirement reduces the sample for R\&D investments from 5,074 to 4,912. I present results for R\&D investments in Table 10. In Table 10, the coefficients on CEO employment history variables are negative when the dependent variable is \#Employers, \#Employers per year or Employer Change Recency, and are positive when the dependent variable is the degree of diversification of CEO experience. The coefficients on the interaction terms of CEO employment history variables and Industry Homogeneity are positive when the dependent variable is \#Employers, \#Employers per year or Employer Change Recency and are negative when dependent variable is Firm or Industry Experience Diversification. These findings suggest that increases in industry homogeneity reduce the negative relation between CEO employment history and R\&D intensity.

Based on the coefficients on \#Employers and \#Employers*Industry Homogeneity, when Industry Homogeneity is above 0.24 , \#Employers relates positively to R\&D Intensity holding other variables constant. When industry homogeneity is less than 0.24 , \#Employers relates negatively to R\&D intensity, ceteris paribus. As a reference point, the sample mean (median) for industry homogeneity is $0.21(0.18)$. When CEO employment history is measured as \#Employers per year and Employer Change Recency, the coefficients on these two variables are positive if industry homogeneity is above 0.34 or 0.21 , respectively. When industry homogeneity is above 0.23 (0.31), Firm (Industry) Experience Diversification relates negatively to R\&D intensity holding other variables constant. These findings support my hypothesis that when the firmspecific knowledge is less important, the risk effect of R\&D dominants and mobile CEOs invest more in R\&D. For coefficients on CEO control variables, older CEOs and CEOs with finance background invest less in R\&D expenditures. 
(3) CEO Employment History and Advertising Intensity

Table 11 presents 2SLS results for advertising intensity. Coefficients on the five employment history variables all have predicted signs and are statistically significant at the $10 \%$ level except for Industry Experience Diversification. CEOs who have worked for more employers, change employers more frequently, change employers more recently and have more diversified firm experience invest more in advertising. These findings support my hypothesis that mobile CEOs invest more in intangible assets which could increase the uncertainty of a firm's future cash flows. For control variables on CEO characteristics, older CEOs spend less in advertising.

Taken together, results in Tables 9 to 11 support my argument that CEOs who change employers more and have more diversified experiences are prone to bear more risk and invest more in intangible investments (e.g., advertising) and less in tangible investments (e.g., capital expenditures). ${ }^{11}$ Mobile CEOs also invest more in R\&D in industries with lower requirements for the firm-specific knowledge.

\subsubsection{Simultaneous Equations: CEO Employment History, financing, and Investment Policies}

CEO hiring decisions, financing and investment policies are likely to be simultaneously determined by the firm. To account for the simultaneity, I estimate the joint determination of CEO hiring decision and firm policies in a system of the following five equations:

Leverage $=(\#$ Employers, CAPEXP, R\&D Intensity, Advertising Intensity, Pre-turnover Leverage,

Depreciation/Total Assets, Operating ROA, Capital Intensity, Firm and CEO Controls)

CAPEXP = (\#Employers, R\&D Intensity, Advertising Intensity, Leverage, Pre-turnover CAPEXP,

Surplus Cash, Firm and CEO controls)

\footnotetext{
${ }^{11}$ I have also estimate the relation between CEO employment history and the intangible ratio. The intangible ratio is measured as the value of intangible assets reported by the firm divided by total assets. I find that mobile CEOs increase the intangible ratio for their firms. Results for the intangible ratios are reported in Appendix B.
} 
$R \& D$ Intensity $=(\#$ Employers, CAPEXP, Advertising Intensity, Leverage, Pre-turnover R\&D Intensity,

Surplus Cash, Firm and CEO controls)

Advertising Intensity= (\#Employers, CAPEXP, R\&D Intensity, Leverage, Pre-turnover Advertising

Intensity, Surplus Cash, Firm and CEO controls)

\#Employers $=(C A P E X P, R \& D$ Intensity, Advertising Intensity, Leverage, Unemployment Rate, Non-

business Career, \# Years working in the current firm's industry, Operating ROA, Firm and CEO controls)

I estimate this system of five equations using three-stage least squares (3SLS). The respective instrumental variables for every policy are listed above in parentheses. The 3SLS results for the total sample are presented in Panel A of Table 12. Results from R\&D investments analysis suggest that the overall effect of CEO employment history on R\&D Intensity is positive when industry homogeneity is high and negative when industry homogeneity is low. Based on the coefficients in Table 10, I estimate the system of equations for a subsample of firms with industry homogeneity above 0.26 (the average of reflection points for all five CEO employment history proxies). Panel B of Table 12 presents 3SLS results for this subsample. Consistent with IV/2SLS estimation results in Tables 8-11, CEOs who have worked for more employers increase leverage, invest more in advertising and less in capital expenditures. For firms in homogeneous industries, CEOs who have worked for more employers also increase investment in R\&D. Results based on other four employment history variables are similar to IV/2SLS estimation results as well. These findings support the hypothesis that mobile CEOs implement riskier firm policies. 


\subsubsection{CEO Employment History and Firm Risk}

Results from prior sections show that CEOs who change employers more and have more diversified firm (industry) experience increase financial leverage, invest more in advertising and R\&D, and less in capital expenditures. The differences in firms' financing and investment policies should impact firm risk. To study the relation between CEO employment history and the riskiness of firm policies, I examine whether firm risk is higher for mobile CEOs. Leverage and the three variables for investment policies are included as additional control variables in firmrisk analysis.

Instrumental variables for firm-risk analysis are the same as the ones described in the firm policy section. The $p$-values of Hansen's J-test and the first-stage $F$-stats, reported in the bottom of Tables 13-15, fail to reject the null hypothesis that these three instrumental variables are valid for firm-risk regressions.

The dependent variable in Table 13 is Total Risk, measured as the annualized standard deviation of daily stock returns. I expect mobile CEOs to increase the firm's Total Risk. Consistent with this hypothesis, the coefficients on \#Employers, \#Employers per year and Employer Change Recency are positive. All these coefficients are statistically significant at the $10 \%$ level. The coefficients on experience diversification variables are negative as predicted. But these relations are not statistically significant at the conventional levels. For other CEO control variables, I find that younger CEOs, CEOs without an MBA degree, and CEOs from the founding family are more likely to increase firm risk.

Because the change in firm policies can influence both systematic and indiosyncratic risk, I next examine do mobile CEOs increase more systematic risk or firm-specific risk. I present 2SLS results for Firm-specific Risk in Table 14 and for Market Risk in Table 15. The dependent 
variable in Panel A of Table 14 is the annualized standard deviation of the residuals from a market model regression of daily returns on the CRSP value-weighted index. The dependent variable in Panel B of Table 14 is the annualized standard deviation of the residuals from the Fama-French three factor model plus a momentum factor. Results are similar in both panels A and B, the coefficients on \#Employers, \#Employers per year and Employer Change Recency are positive and statistically significant. The coefficients on firm experience diversification are negative and statistically significant at the $5 \%$ level when the firm-specific risk is measured by the four-factor model and at the $10 \%$ level when the firm-specific risk is measured by the market model. Industry experience diversification relates negatively to the firm's specific risk, but this relation is significant at the $10 \%$ level for the four-factor model only. Similar to findings in Kothari et al. (2002), the coefficients on R\&D intensity are much higher than the coefficients on capital expenditures, which suggest that investments in $R \& D$ intensity increase firm risk more than investments in capital expenditures. Consistent with the notion that a higher leverage increases firm risk, the coefficient on leverage is positive and statistically significant at the $1 \%$ level for all the models in both tables. Older, larger and more profitable firms have lower firmspecific risk. Similar to the findings for Total Risk, younger CEOs, CEOs without an MBA degree and from the founding family are more likely to increase Firm-specific Risk.

In Table 15, the dependent variable is Market Risk, which is the market beta from the market model regression. None of the coefficients on the five employment history proxies are statistically significant. This finding suggests that mobile CEOs do not change the market risk of their firms. CEOs from the founding family increase Market Risk when the CEO employment history is measured as Industry Experience Diversification. None of the other CEO characteristics relates to a firm's market risk. 
Because increases in a firm's financial leverage will increase the firm's equity beta, I construct an unlevered beta to examine the relation between CEO employment history and the firm's systematic asset risk. To unlever the equity beta, I assume the debt has a beta of zero and multiply the firm's equity beta by (1- Leverage). Panel B of Table 15 presents results for unlevered betas. The coefficients on \#Employers, \#Employers per year, Employer Change Recency are negative and statistically significant at the $10 \%$ level. The coefficients on Firm and Industry Experience Diversification are positive and statistically significant at the $5 \%$ level. ${ }^{12}$ These findings suggest that mobile CEOs reduce their firms' unlevered beta, but use leverage to help maintain the overall CAPM beta.

To control for the possibility that the CAPM model does not fully capture the systematic risk of the firm, I examine the relation between CEO employment history and betas estimated from the four-factor model. The analysis on the factor betas helps to understand whether mobile CEOs change the systematic risk of a firm's assets. The betas estimated from the four-factor model are a size beta, a book-to-market beta and a momentum beta. I report results for the size beta in Panel C of Table 15, for the book-to-market beta in Panel D of Table 15, and for the momentum beta in Panel $\mathrm{E}$ of Table 15. I find mobile CEOs do not influence the size beta and the momentum beta, but they increase the book-to-market beta. When the book-to-market beta is the dependent variable, $p$-values for the five CEO employment history variables range from 0.062 to 0.124. These findings suggest that mobile CEOs possibly influence the growth potential of the firm.

\footnotetext{
${ }^{12}$ I obtain similar results if I unlever the equity beta using a debt beta of 0.2 (Conine and Tamarkin, 1985). The coefficients on Firm (Industry) Experience Diversification, however, are statistically significant at the 10\% level instead of the $5 \%$ level..
} 
If a mobile CEO changes the systematic risk of the firm, one would expect the firm's asset structure to change. To shed light on whether the CEO changes the firm's asset structure, I examine the likelihood of adding or reducing a segment and the concentration of segment operation within the firm. Panel F of Table 15 reports results on the concentration of segment operations. The coefficients on \#Employers are negative and statistically significant. This finding suggests that mobile CEOs reduce the concentration of segment sales, operating income, capital expenditures and assets. The positive and statistically significant coefficients on Industry Experience Diversification suggest that CEOs with concentrated industry experience increase the concentration of segment operations. To examine the likelihood of a CEO to add or reduce a segment or SIC code, I create a category variable that equals one if the CEO reduces the number of segments for his firm, equals two if there is no change in the number of segments, and equals three if the CEO increases the number of segments. I report multinomial regression results on this category variable in Panel G of Table 15. The base case for the multinomial regression is the second category where there is no change in the number of segments. CEOs that change employers more are more likely to add a segment or a segment with a new SIC code. CEOs that have diversified industry experience are less likely to add and reduce a segment or SIC code for their firms. These findings support the argument that CEO employment history relates to the firm's asset structure.

Taken together, the firm-risk analysis suggests that CEOs who change employers more frequently and have more diversified experience increase firm risk. The increase in total firm risk comes from increases in firm-specific risk, but not the CAPM market risk. 


\subsubsection{Principal Component Analysis on CEO Employment History Variables}

In this section, I use the principal component analysis to construct one variable that incorporates both positive and negative correlations between the five CEO employment history variables. I present the loadings of the CEO employment history variables on the principal components in Panel A of Table 16. Among the five extracted components, the first component has an eigenvalue above four and explains more than $80 \%$ of the variations. None of the other components have an eigenvalue more than one and each of them explains less than $5 \%$ of the total variation. \#Employers, \#Employers per year and Employer Change Recency load positively on the first component and Firm (Industry) Experience Diversification load negatively on the first component. Therefore, CEOs with high values for the first component are mobile CEOs that change employers more frequently and have more diversified experience.

I repeat the firm policies and risk analysis using the first component as a proxy for CEO employment history. Results are presented in Panel B of Table 16. Similar to results in prior sections, CEOs with high values for the first component increase Leverage, invest less in Capital Expenditures and more in advertising. They also invest more in $R \& D$ in homogeneous industries. As a result of riskier firm policies, these CEOs increase their firms' Total Risk, especially Firm-specific Risk.

The results presented so far suggest that CEOs with different employment histories adapt firm policies with different risk levels. In particular, CEOs with more employer changes and more diversified firm (industry) experience take on higher levels of debt, invest more in advertising and less in capital expenditures. Mobile CEOs also invest more in R\&D in homogenous industries. As result, mobile CEOs' firms have higher firm risk. These results are 
robust to estimating a system of simultaneous regressions and using a principal component to capture the positive and negative correlations in the five CEO employment history variables.

\section{CEO Employment History and Firm Performance}

The results in the previous section support the hypothesis that CEOs with different employment histories undertake different firm policies. In this section, I examine if the differences in firm policies and risk affect shareholders' wealth and lead to inefficiencies in firm performance. In section 6.1, I examine announcement returns for CEO turnovers. In section 6.2, I study whether subsequent firm performance differs for CEOs with different employment histories.

6.1 Event Study Results for shareholders

From the original 1,144 CEOs, I find announcement dates for 901 CEOs. To compare turnover announcement returns for CEOs who have worked for different numbers of employers, I separate these $901 \mathrm{CEOs}$ into four groups based on the quartiles of \#Employers. The first group includes CEOs who have worked for only one employer. The fourth group includes CEOs who have worked for at least five employers. I compare how announcement returns differ for CEOs in the first and fourth groups. I report t-statistics for the market model CARs based on Patell (1976). I also report a nonparametric generalized sign statistic to test whether percentage of positive returns differs significantly from the estimation period. The event study results are presented in Table 16. CARs based on value-weighted market index are report for two event windows $[-1,1]$ and $[-3,1]$. Day -1 is the day before the day of CEO turnover. Day 1 is one day after the date of CEO turnover announcement. The second event window is used to control for 
possible information leakage. I obtain similar results when use equally-weighted market index in the market model.

For all types of turnovers, the average announcement CARs for 175 CEOs who have worked for only one employer (first group) is negative and significantly different from zero for the event window $[-3,1]$. For 185 CEOs who have worked for at least five employers (fourth group), the average announcement CAR is positive and significantly different from zero at the $1 \%$ level. To control for the insider/outsider effect, I classify CEOs into insiders or outsiders within the fourth group. For 80 insider CEOs who have worked for more than four employers, the average of announcement CARs is $0.91 \%$ for the event window $[-3,1]$ and $1.02 \%$ for the event window $[-1$, 1]. Both CARs are statistically significant at the $10 \%$ level. For the 105 outsider CEOs that have worked in more than four firms, the CARs are positive and statistically significant at the 5\% level.

If mobile CEOs are less risk averse and are more likely to bring changes to a firm, one would expect shareholders to react positively to appointments of mobile CEOs when the firm needs to change its prior strategies. Shareholders would expect a change in firm policies when the firm dismisses the prior CEO or when the firm has a poor prior performance. I follow Parrino (1997) to classify a turnover as forced when news stories indicate that the CEO has been ousted, there were conflicts between the CEO and the board, the CEO resigned following poor performance, the CEO resigned or retired following an SEC investigation or class action lawsuit, or the CEO resigns without an outside job appointment within six months and the CEO is below the age of 60. For 175 turnovers in the first group, 11 are forced turnovers and 147 are unforced turnovers. The other 17 turnovers are results of sudden CEO death, mergers/acquisitions or spin-offs. For 185 turnovers in the fourth group, 36 are forced turnovers and 122 are unforced turnovers. The 
other 27 turnovers are results of sudden CEO death, mergers/acquisitions or spin-offs. I exclude turnovers that are results of sudden $\mathrm{CEO}$ death, mergers/acquisitions. The findings are similar to the results on all turnovers. For CEOs that have worked for only one firm, the average CAR is negative and statistically significant for the forced turnover subsample. When the firm dismisses their CEOs, shareholders anticipate a change in the firm's strategy. The fact that the firm appoints a new CEO who has only worked in the current firm suggests a lower probability of changing in current policies or a lack of CEO candidates. In either case, one would expect the stock market to react negatively. On the other hand, investors react positively when the new CEO makes more employer changes. The positive stock price reaction holds for both forced turnovers and normal successions and for insider and outsider successions.

When the firm's prior performance is poor, shareholders would likely expect the firm to hire a CEO to change the firm's prior policies. I separate the CEO turnover sample into two groups based on whether their firms' prior stock returns are above or below the industry median. In Table 17, when the firm has good prior performance, the CARs are not statistically different from zero for firms that appoint a non-mobile CEO and firms that appoint a mobile CEO. However, the percentage of firms with negative CARs is higher in the sample of firms that appoint a mobile $\mathrm{CEO}$ as the new $\mathrm{CEO}$. When the firm's prior performance is below industry median, shareholders react positively when the firm appoints a mobile CEO and negatively when the firm appoints a CEO that has only worked for the current firm. The positive shareholder reaction for mobile CEOs is robust for both insider- and outsider- successions. The results support the argument that shareholders react positively for the appointment of a mobile CEO when the firm has a need to change its prior policies. 
The results from the event study provide evidence that shareholders view the appointment of a CEO that changes employers multiple times as a positive signal for the firm's future. This result has two possible interpretations. One interpretation is that shareholders react positively when the new CEO is less risk averse, which reduces agency costs created by differences in attitudes toward risk between shareholders and managers. Another explanation is that shareholders react positively because they believe CEOs who worked for multiple firms differ in other characteristics, such as education, age, and functional backgrounds. To separate these two effects, I regress the announcement CARs on CEO employment history and other CEO characteristics. I also include firm size, prior performance, year dummies and industry dummies as additional control variables.

The results from the cross-sectional CARs' regressions are presented in Table 18. The dependent variable in Table 18 is the cumulative abnormal return based on the event window of $[-3,1]$. I use weighted least square (WLS) to estimate the coefficients. The weights in WLS are the inverse of the standard deviation of the market model residuals. \#Employers relates positively to the CARs, but this relation is not statistically significant at the conventional level. To control for the possibility that the relation between \#Employers and CARs are not strictly monotonic, I then substitute \#Employers by the quartile rank based on \#Employers. The top quartile, CEOs that have worked for at least five employers, has a quartile rank value of 4 . The bottom quartile, which includes CEOs that have worked for only one employer, has a quartile rank value of 1 . The coefficient on the quartile rank is positive and statistically significant. None of the other CEO characteristics appear to relate to the CARs. This finding suggests that the positive shareholder reaction obtained in event studies are driven by the CEO's employment history, not by other CEO characteristics. The CARs relate negatively to the firm's prior 
performance. I repeat the CARs regression in the subsample of insider successions and obtain similar results. Forced turnovers, however, are associated with negative CARs in the insider subsample. Because CEOs with no employer change are all insiders, this finding is consistent with the event study result that shareholders react negatively to the appointment of CEOs with no employer change when the turnover is forced.

\subsection{Long Run Accounting and Stock Performance}

In this section, I examine whether CEOs who change employers more perform differently than CEOs with fewer employer changes. As in event studies, I separate CEOs into four groups based on the quartiles of the number of employers they have worked for. The first group has CEOs that have only worked for one employer and the fourth group includes CEOs that have worked for at least five employers. I present the changes in industry-median-adjusted performance from a year before the CEO turnover to three years after the CEO turnover. Differences in changes in performance between group 1 and group 4 are included at the right side of the table. The statistical significances are based on $p$-values from t-tests for differences in means and from non-parametric signed rank test for differences in distribution. Appendix A includes the construction for the five performance variables. Table 1 presents summary statistics for these performance variables. The average (median) return on equity for my sample is 0.130 (0.130). Industry-median-adjusted ROE has a mean of 0.064 and a median of 0.050 . The average (median) operating return on assets is $0.100(0.100)$ and industry-median-adjusted values are $0.060(0.041)$. Annual stock returns and industry-median-adjusted annual stock returns have means of $10.4 \%$ and $8.2 \%$, respectively. Industry medians are computed on the basis of Fama and French 48 industry as described in Fama and French (1997). 
Table 19 presents results for industry-median-adjusted performance changes from the year before the year of CEO turnover to three years after CEO turnover. To test my hypotheses, I focus on the differences in changes in performance between group 1 and group 4. Group 1 includes CEOs who have worked for only one employer and group 4 includes CEOs who have worked for at least five employers. From the year before the CEO turnover to a year after the CEO turnover ( $t=-1$ to $t=1)$, there are no difference between group 1 and group 4 in OROA, ROE, and Tobin's Q. However, CEOs that have worked for at least five employers increase annual stock returns more than CEOs who have worked for only one employer. This result holds when changes in performance are measured from the year before CEO turnover to two years after CEO turnovers $(t=-1$ to $t=2)$. In the third year after CEO turnovers, there is no difference in changes in stock returns. CEOs who have worked for at least five employers have better sales growth than CEOs who have worked for only one employer for all three years after the year of CEO turnover. The difference is statistically significant for the third year after the CEO turnover. Risky firm policies should result in greater variance in outcome. I test whether the crosssectional variance in firm performance is greater for the group of CEOs who have worked for at least five employers than the group of CEOs who have worked for only one firm. I present $p$ values from the $F$-test on the equality of variances in the last column of Table 19. Except for sales growth in the second year, cross-sectional variance in firm performance is consistently higher for the group of CEOs who have worked for at least five firms. I next study variances of these performance variables for all post-turnover firm years. Panel B of Table 19 presents $p$ values from the Levene's Test for homogeneity of variance. Consistent with the findings in Panel A, the variance in performance is different for CEOs that have worked for different numbers of employers. The group of CEOs that have worked for at least five firms have much higher 
variance in their performance measures than the group of CEOs that have only worked for one employer.

In sum, CEOs with more employer changes have better sales growth and stock performance than CEOs with no employer change. However, there are no differences in accounting performance for CEOs with different numbers of employer changes. CEOs that change employers more also have higher volatility in their performance.

\section{Impact on Bondholders}

Results from the analysis on firm policies, risk and performance suggest that mobile CEOs implement riskier firm policies and increase a firm's idiosyncratic risk. Shareholder reacts positively to the appointments of mobile CEOs, but the overall accounting performances are not different for CEOs with different numbers of employer changes. These findings merit a question: Is there a wealth transfer from shareholders to bondholders? If the answer is yes, one would expect bondholders to react negatively to the appointments of mobile CEOs and the firm's cost of debt should increase after the firm hires a mobile CEO. In section 7.1, I examine bondholders' reaction to appointments of mobile CEOs using the bond trading data from Mergent Fixed Income Securities Database (FISD). In section 7.2, I examine how costs of debt change for firms that hire mobile CEOs.

\subsection{Event Study for Bondholders}

Mergent FISD database has a bond transaction dataset that includes daily bond transactions from 1995 to 2005 by insurance firms reported in Schedule D of the National Association of Insurance Commissioners (NAIC) regulatory filings. For 837 turnovers in my sample that happen between 1995 and 2005, 588 of them have transaction data in Mergent's bond transaction 
database. After excluding bonds that have variable rates, are putable or convertible, the fixed coupon bond sample contains 449 firms. I follow Maxwell and Stephens (2003) to calculate abnormal bond returns around CEO turnover announcements. To be included in the event study for bondholders, I require a bond to have transaction data for the month of the CEO turnover (232 firms dropped) and for four months prior to the CEO turnover (96 firms dropped). This requirement reduced the sample from 449 firms to only 121 firms.

Monthly bond returns are calculated as price plus accrued interest. If there are multiple transactions for a given bond in a given month, I calculate a monthly value-weighted average bond return using the par amounts of each transaction as weights. To account for changes in term structure, I calculated monthly bond return premium as the bond's monthly return minus the return on a Treasury security with a closest time to maturity. I then compute the mean expected bond return premium as the average monthly bond return premium for months -4 to -2 . Month -4 is the fourth month prior to the CEO turnover month and month -2 is the second month prior to the CEO turnover month. The abnormal monthly bond returns are then computed as the difference between the actual and the expected bond return premiums. If there is more than one bond outstanding for a firm, I compute a weighted-average abnormal return on bonds for the firm using outstanding par values for each bond as weights.

Table 20 presents results on announcement bond returns. In additional to abnormal bond return premiums, I also report abnormal yield to maturity, abnormal spread, and abnormal bond returns. Out of the 121 turnovers, 34 firms hire CEOs that have worked for only one employer and 24 firms hire CEOs that have worked for at least five employers. Consistent with my hypothesis, bondholders react negatively when the firm appoints a mobile CEO and positively when the firm appoints a CEO that has never changed employers. However, these differences are 
not statistically significant. The signs from the event study for bondholders are consistent with my hypothesis, but the small sample size limits my ability to draw strong conclusions.

\subsection{Impact on the Cost of Debt}

I next examine how the cost of debt changes after a firm appoints a mobile CEO. I measure a firm's cost of debt using the fiscal-year-end bond yield spread and the S\&P long-term bond rating. Bond yield spreads are estimated from the Mergent's bond transaction database. S\&P long-term debt rating is from the Compustat Fundamental Annual database. I present summary statistics for these two variables in 7.2.1. I report results on bond yield spread in Section 7.2.2 and results on credit rating in Section 7.2.3.

\subsubsection{Summary Statistics for the Cost of Debt Variables}

I follow a standard procedure in the literature (e.g., Anderson et al., 2003, Elton et al. 2001, and Prevost et al. 2008) to estimate a bond's yield spread. Based on the Mergent's bond transaction database, I first identify a bond transaction date that is closest to the firm's fiscal year end. I then calculate the yield to maturity for every bond transaction price on that date. I estimate the yield spread for a bond as the bond's yield to maturity minus the yield to maturity on a Treasury security with the closest time to maturity. If there are multiple transactions for a given bond in a given day, I calculate a daily value-weighted average yield spread using the par amounts of each transaction as weights. I follow the same procedure to compute bond duration and convexity. To be included in the bond spread analysis, the firm must have bond yield data for the year prior to the year of CEO turnover. The final sample for bond yield study includes 210 firms and 718 firm years. 
Standard \& Poor's rates a firm's long-term debt from D (the lowest grade) to AAA (the highest grade). I translate rating letters into numbers with AAA represents 1 and D represents 19. After excluding firms with negative book equity, the lowest rating in my sample is 16 (B-). Out of the original 5,139 firm years, 2,866 firm years have bond rating data. After requiring the firm to have bond rating data in the year prior to the year of CEO turnover, the sample size for bond rating analysis reduces to 1,998 firm years.

Table 21 presents summary statistics for bond spread and rating variables. The average bond rating for 1,998 firm years are 8.6 and the median bond rating is 9 (BBB). The average (median) bond spread for 718 firm years is $0.022(0.015)$. I present a distribution of the sample firms in different rating categories in Panel B of Table 21. All my sample firms have a rating above B-. About $69 \%$ of my sample firms have investment grade (BBB-) and above.

\subsubsection{CEO Employment History and Bond yield Spread}

To examine the impact of CEO employment history on a firm's cost of debt, I use IV/2SLS estimation approach to estimate the following model:

Bond Yield Spread $=b_{1}$ CEO Employment History Proxy $+b_{2}$ Pre-turnover Yield Spread $+b_{3}$ Duration +

$$
\begin{aligned}
& b_{3} \text { Convexity }+b_{4} \text { Firm Control Variables }+b_{3} \text { CEO Control Variables }+ \text { Industry } \\
& \text { Dummies }+ \text { Year Dummies }+e
\end{aligned}
$$

In addition to the control variables used in firm policy analysis, I also include bond duration and convexity as additional controls for bond structure.

Instrumental variables are the same as those in firm policy analysis. Table 22 present regression results on bond yield spreads. The coefficients on \#Employers, \#Employers per year, and Employer Change Recency are positive. The coefficient is statistically significant at the 10\% level for \#Employers. Firm and Industry Experience Diversification relate negatively to yield spreads. The coefficient on Industry Experience Diversification is statistically significant at the 
$10 \%$ level. If the firm's bond rating is already low, the new CEO would be less likely to further increase the firm's financial risk. I repeat the analysis for a subsample of firms with crediting rating at BBB- and above. Results, in Panel B of Table 22, are stronger than those reported for the whole sample. Coefficients on the five employment history variables are all statistically significant at the $10 \%$ level. These findings are consistent with the argument that the cost of debt increases after the firm appoints a mobile CEO.

\subsubsection{CEO Employment History and Credit Rating}

To examine the relation between CEO employment history and the change in a firm's credit rating, I estimation the following model:

$S \& P$ Credit Rating $=b_{1} C E O$ Employment History Proxy $+b_{2}$ Pre-turnover Credit Rating $+b_{3}$ Firm Control Variables $+b_{4} C E O$ Control Variables + Industry and Year Dummies $+e$

To support the hypothesis that mobile CEOs increase a firm's cost of debt, I expect $b_{1}$ to be positive when the CEO employment history is measured as \#Employers, \#Employers per year and Employer Change Recency and to be negative when the CEO employment history is measured as diversification levels of the CEO's firm or industry experience. I present results on S\&P credit ratings in Table 23. Coefficients on the five employment history variables all have the predicted signs, but none of these coefficients are statistically significant at the conventional levels.

If a firm's default risk is already significant, even a mobile CEO would be reluctant to further increase firm risk. Therefore, one would not expect mobile CEOs to downgrade bond rating for firms that already have a low bond rating. I repeat the bond rating regression in a subsample of firms with a rating of BBB- or above. Because agencies are slow to change a firm's bond rating (e.g., Contor, 2001, and Baker and Mansi 2002), I also exclude observations from the first year after a CEO turnover in the analysis. Panel B of Table 23 present results for this subsample. 
CEOs that change employers more frequently and have more diversified experience increase the credit rating number, which implies that these CEOs decrease their firms' bond ratings. This result is consistent with the proposition that mobile CEOs increase the firm's cost of debt. However, how diversified is the CEO's industry experience does not influence the firm's bond rating.

In summary, the analysis on bondholders indicates that the cost of debt increases after a firm hires a mobile CEO, especially for firms with investment-grade bond ratings. The findings that mobile CEOs increase financial leverage, firm-specific risk, shareholders' wealth, and the cost of debt suggest that the risk-shifting from shareholders to bondholders is one source of shareholder value increase.

\section{Conclusion}

In the announcements of CEO appointments, firms often give a detailed employment history of the new CEO, which suggests that employment history conveys useful information to shareholders. I argue that CEO employment history reflects a CEO's propensity to bear risk and hypothesize that CEOs who change employers more frequently and have more diversified firm or industry experience implement riskier firm policies.

Using a sample of S\&P 1500 CEOs, I find that when firm risk is high, firm-specific human capital is less important, the board is smaller and has fewer insiders, the prior CEO was dismissed and the prior CEO has a shorter tenure, firms hire mobile CEOs that change employers more and have more diversified experience. The firm is more likely to hire a CEO with diversified industry experience when the firm experiences negative industry or firm-level shocks prior to the CEO turnover. Mobile CEOs increase financial leverage, invest more in advertising 
and less in capital expenditures. They also invest more in R\&D in homogenous industries where the firm-specific knowledge is less important and invest less in R\&D in less homogenous industries where the firm-specific knowledge is more important. As a result of riskier firm policies, mobile CEOs increase the firm's total risk. But the increase in the firm's total risk comes from increase in firm-specific risk, not market risk.

I also find that stockholders react positively to appointments of CEOs who have changed employers multiple times. For the appointments of CEOs with no employer change, the turnover announcement returns are negative for forced turnovers and not different from zero for unforced turnovers. Shareholders also react positively to appointments of mobile CEOs when the firm's prior performance is poor. CEOs who have worked for at least five employers also achieve better long-run stock performance and higher sales growth for their firms. However, for three years following the CEO turnover, I find no difference in accounting performance for CEOs with different employment histories. Taken together, these results suggest that lower CEO risk aversion and the potential risk-shifting from shareholders to bondholders are sources of shareholder value increases. In support of the risk-shifting argument, I find mobile CEOs increase their firm's cost of debt, especially in firms with low default risk.

My results provide evidence that CEO employment history relates to risk-taking in firm policies. This paper adds to a growing literature that finds evidence on how managerial styles and risk preferences affect firm policies and performance (e.g., Bertrand and Schoar, 2003; Kaplan et al., 2008; Graham et al., 2008; Malmendier and Tate, 2005 and 2007). The results in this paper suggest that CEO employment history is an observable characteristic that reveals the risk-taking propensity of CEOs. This relation between risk-taking traits and employment history has implications for future research. For instance, can employment history help boards of 
directors identify better CEO-firm matches? Or design better incentive compensation packages?

The answers to these questions could provide additional useful information to both decision makers and researchers. 


\section{Appendix A\&B:}

Appendix A: Variable Constructions for firm-and industry-level variables.

\section{Appendix B: Robustness Tables}

B.1 Alternative Model Specifications

(1). Alternative Dependent Variables

Table B.1.1: Use industry-median-adjusted policies as dependent variables

Table B.1.2: Use change in policies as dependent variables

Table B.1.3: Use Book Leverage as the dependent variable

Table B.1.4: Use Intangible Ratio as the dependent variable

Table B.1.5: Use Four-factor model betas as dependent variables

(2). Alternative CEO Employment History Measures

Table B.1.6: Using values in the year of CEO turnover for CEO employment history measures (The values for these variables will not change for every firm year)

Table B.1.7: Including an interaction term between CEO employment history and a dummy variable that equals one if the respective pre-turnover firm policy is above industry median.

(3). Control Variables

Table B.1.8: Subsample with Board Size and Insider Ratio Information

Table B.1.9: Include a insider dummy

Table B.1.10: Industry Dummies, no Herfindhal Index

B.2 Alternative Estimation Methods

Table B.2.1: OLS Results

Table B.2.2: Between effects

Table B.2.3: Heckman Selection Model when the dependent variable is a dummy variable that equals one if the $\mathrm{CEO}$ has worked for more than five employers and zero otherwise

Table B.2.4: Subsamples of the first-five (three) years' policy of CEOs that have been the CEO for five (three) or more years

Table B.2.5: Comparison of long-run performance using a matched sample

B. 3 Results for other CEO employment history variables.

These results are discussed in the text, but only presented for \#Employer. This section include the results for other four CEO employment history variables

Table B.3.1: Univariate Comparison for Pre-turnover firm policies 


\section{Reference:}

Adams, R. B., H. Almeida, and D. Ferreira, 2005, Powerful CEOs and their Impact on Corporate Performance, Review of Financial Studies 18, 1403-1432.

Allen, J.W., and G.M. Phillips. 2000, Corporate equity ownership, strategic alliances, and product market relationships., Journal of Finance 55, 2791-2815.

Allgood, S. and K. A. Farrell, 2003, The Match between CEO and Firm, Journal of Business, 76 (2), 317-341.

Amir, E., Y. Guan, and G. Livne, 2007, The Association of R\&D and Capital Expenditures with Subsequent Earnings Variability, Journal of Business Finance \& Accounting 34, 222-246.

Anderson, M., S. Mansi, and D. Reeb, 2003, Founding family ownership and the agency cost of debt, Journal of Financial Economics 68, 263-285

Baker, H.K. and S.A. Mansi, 2002, Assessing credit agencies by bond issuers and institutional investors, Journal of Business Finance and Accounting 29, 1367-1398.

Becker, G. S., 1962, Investment in human capital: A theoretical analysis, Journal of Political Economy 70, 9 - 49.

Bertrand, M. and A. Schoar, 2003, Managing with style: The effect of managers on firm policies, Quarterly Journal of Economics, 118 (4), 1169-1208.

Cantor, R., 2001, Moody's investors service response to the consultative paper issued by the Basel Committee on Bank Supervision 'A New Capital Adequacy Framework', Journal of Banking and Finance, 25.

Coles, J., N. Daniel, and L. Naveen, 2006, Managerial incentives and risk-taking, Journal of Financial Economics, $79,431-468$.

Conine, T. E. and M. Tamakin, 1985, Divisional cost of capital estimation: Adjusting for leverage. Financial Management, 14 (1), 54-58.

Core, J., and Guay, W., 1999. The use of equity grants to manage optimal equity incentive levels. Journal of Accounting and Economics 28, 151-184.

Core, J., and Guay, W., 2002a. Estimating the value of employee stock option portfolios and their sensitivities to price and volatility. Journal of Accounting Research 40, 613-630.

DeFusco, R., Johnson, R., Zorn, T., 1990. The Effect of Executive Stock Option Plans on Stockholders and Bondholders. Journal of Finance 45(2), 617-627.

Elton, E. J., M. J. Gruber, D. Agrawal, and C. Mann, 2001, Explaining the Rate Spread on Corporate Bonds, the Journal of Finance, 56, 247-277

Fama, E., 1980, Agency problems and the theory of the firm, Journal of Political Economy, 88 (2).

Fama, E. and K. French, 1997, Industry costs of equity, Journal of Financial Economics 43, 153-193.

Galai, D. and R. Masulis, 1976, The Option Pricing Model and the Risk Factor of Stock, Journal of Financial Economics, January/March, 53-81.

Gilson, S., 1989, Management turnover and financial distress. Journal of Financial Economics 25, 241-62. 
Gilson, S., 1990, Bankruptcy, boards, banks, and blockholders: Evidence on changes in corporate ownership and control when firms default, Journal of Financial Economics 27, 355-387.

Gilson, S., and M. Vetsuypens, 1993, CEO Compensation in financially distressed firms: An empirical analysis, Journal of Finance 48, 425-58.

Graham, J., C. R. Harvey, and M. Puri, 2007, Managerial Attitudes and Corporate Actions, Duke University working paper.

Hackbarth, D., 2007, Managerial Traits and Capital Structure Decisions, Washington University working paper.

Hambrick, D., 2007, Upper Echelon Theory: An Update, Academy of Management Review, 32 (2), 334-343.

Harris, M. and Y. Weiss, 1984, Job Matching With Finite Horizon and Risk Aversion, Journal of Political Economy, 92, 4, 758-779.

Haugen, R., Senbet, W., 1981. Resolving the agency problems of external capital through options. Journal of Finance 36, 629-647.

Jovanovic, B.. 1979a. Job Matching and the Theory of turnover. Journal of Political Economy 87. 972-990.

Jovanovic, B.. 1979b. Firm-specific Capital and Turnover. Journal of Political Economy 87. 1246-1260.

Kahneman, D., and A. Tversky, 1979, Prospect Theory: An Analysis of Decision under Risk, Econometrica, 47, 263-291.

Kale, J., H. Shahrur. 2007. Corporate capital structure and the characteristics of suppliers and customers. Journal of Financial Economics 83 321-365.

Kaplan, S., M. M. Klebanov and M. Sorensen, 2007, Which CEO Characteristics and Abilities Matter? University of Chicago and NBER working paper.

Kothari, S., Laguerre, T., and Leone, A., 2002, Capitalization versus expensing: evidence on the uncertainty of future earnings from capital expenditures versus R\&D outlays, Review of Accounting Studies, 7 (4), 355-382.

Malmendier, U., and G. Tate, 2005, CEO overconfidence and Corporate Investment, Journal of Finance, 60(6), 2661-2700.

Malmendier, U., and G. Tate, 2007, Who Makes Acquisitions? CEO Overconfidence and the Market's Reaction, Journal of Financial Economics, forthcoming.

Maxwell, W., and C. P. Stephens, 2003, The Wealth Effects of Repurchases on Bondholders, the Journal of Finance, 58(2), 895-919.

Myers, S.C. , 1977, Determinants of corporate borrowing, Journal of Financial Economics, 5, 147-175.

Mortensen, D., 1978. Specific capital and labor turnover. The Bell Journal of Economics 9, 572-586.

Lewellen, K., 2006, Financing decisions when managers are risk averse, Journal of Financial Economics, 82 (3), 551-589. 
MacKay, P., and G. Phillips. 2005. How does industry affect firm financial structure, Review of Financial Studies 18(4) 1433-1466.

Nicholson, N., and West, M. A., 1988, Managerial Job Change: Men and women in transition, Cambridge: Cambridge University Press.

Nicholson, N., E. Soane, E., M. Fenton-O'Creevy and P. Willman, 2005, Personality and domain-specific risk taking. Journal of Risk Research, Vol. 8: 157-176.

Oyer, P., 2006, Initial Labor Market Conditions and Long-Term Outcomes for Economists, Journal of Economic Perspectives, 20, 143-160.

Oyer, P., 2008, The Making of an Investment Banker: Macroeconomic Shocks, Career Choice, and Lifetime Income, The Journal of Finance.

Parrino, R., 1997, CEO turnover and outside succession: A cross-sectional analysis, Journal of Financial Economics, 46, 165-197.

Patell, J., 1976, Corporate Forecasts of Earnings Per Share and Stock Price Behavior: Empirical Tests, Journal of Accounting Research 14, 246-276.

Pfeifer, C., 2008, A Note on Risk Aversion and Labour Market Outcomes: Further Evidence from German Survey Data, the Institute for the Study of Labor working paper.

Pissarides, C., 1974, Risk, Job Search and Income Distributions, Journal of Political Economy 82 (6), 1255-1267.

Pissarides, C., 1976, Job Search and Participation, Economica 43, 33-49.

Raheja, C., 2005, Determinants of board size and composition: A theory of corporate boards, Journal of Financial and Quantitative Analysis 40, 283-306.

Rajan R., and L. Zingales. 1995. What do we know about capital structure? Some evidence from international data. Journal of Finance 50 1421-1460.

Rajgopal, S., and Shevlin, T., 2002. Empirical evidence on the relation between stock option compensation and risk taking. Journal of Accounting and Economics 33, 145-171.

Ryan Jr., H., and Wiggins III, R., 2001. The Influence of Firm- and Manager-Specific Characteristics on The Structure of Executive Compensation, Journal of Corporate Finance, 2001, Vol. 7, No. 2, 101-123

Ryan Jr., H., and Wiggins III, R., 2002. The interactions between R\&D investment decisions and compensation policy. Financial Management 31, 5-29.

Titman, S., and R. Wessels, 1988. The determinants of capital structure choice. Journal of Finance, 43, 1-40.

Vancil, R.F., 1987, Passing the baton: Managing the process of CEO succession. Harvard University Press.

Vesterlund, L., 1997, The effect of risk aversion on Job Matching: Can Differences in Risk Aversion Explain the Wage Gap? Iowa State University working paper.

Weisbach, M., 1988, Outside directors and CEO turnover, Journal of Financial Economics 20, 431-460. 


\section{Appendix A: Firm and Industry Variable Construction}

Firm Policies:

- Leverage equals the book value of long-term debt (Compustat item 9) plus debt in current liabilities (Compustat item 34) divided by long-term debt plus debt in current liabilities plus the market value of equity (Compustat item 25*Compustat item 199).

- $\mathrm{R} \& \mathrm{D}$ Intensity is the ratio of $\mathrm{R} \& \mathrm{D}$ expenditures (Compustat item 46) to total assets (Compustat item 6).

- Advertising Intensity is measured as advertising expenses (Compustat item 45) divided by total assets (Compustat item 6).

- Capital Expenditures, CAPEX, is defined as capital expenditure (Compustat item 128) divided by total assets (Compustat item 6).

- Total Risk is the standard deviation of daily stock returns multiplied by the square root of 254 trading days.

- Firm-specific risk (Market) is measured as the annualized standard deviation of the residuals from a market model regression of daily returns on the CRSP value-weighted index multiplied by $254^{1 / 2}$. To compute this firm-specific risk measure, I require a firm to have at least 30 days of returns for that fiscal year.

- Firm specific risk (FF+Momentum) is the annualized standard deviation of the residuals from a regression of daily stock returns on the three Fama-French factors plus a momentum factor.

- Market risk is the beta on the market index from the market model regression used to obtain firm-specific risk (Market). 
Executive Compensation Variables:

- CEO Current Compensation is computed as salary plus bonus divided by total compensation (Execucomp item tdc2)

- CEO Compensation Delta is the sensitivity of the CEO's wealth with respect to a $1 \%$ change in stock price. CEO's portfolio Delta is computed as the weighted average of the delta of the CEO's stock and the delta of CEO's options. Delta of the CEO's stock $=\%$ Shareowned by the CEO*0.01*stock price. Delta of a CEO's options is computed as in Core and Guay (2002), Guay (1999), and Coles et al. (2006).

- CEO Compensation Vega is defined as the sensitivity of the option value with respect to a 0.01 change in stock volatility. I use a CEO's option Vega as the CEO's portfolio Vega. A CEO's option Vega = Vega of new options granted + Vega of all exercisable options held + Vega of all unexercised options held. Each individual Vega in the equation is computed as in Core and Guay (2002), Guay (1999), and Coles et al. (2006). Risk free rate used in Vega and Delta computation is from the ten-year treasury bills constant maturity series available from the Federal Reserve Bank's official website. My results are robust if I use the rates of five-year or seven-year treasury bills as the risk free rates.

Cost of Debt Variables:

- S\&P Credit Rating: S\&P long-term debt rating is from the Compustat Fundamental Annual database. I translate rating letters into numbers as follows:

\begin{tabular}{cc} 
S\&P Credit Rating Letter & Rating \\
\hline AAA & 1 \\
AA+ & 2 \\
AA & 3 \\
AA- & 4 \\
A+ & 5
\end{tabular}




$\begin{array}{cc}\mathrm{A} & 6 \\ \mathrm{~A}- & 7 \\ \mathrm{BBB}+ & 8 \\ \mathrm{BBB} & 9 \\ \mathrm{BBB}- & 10 \\ \mathrm{BB}+ & 11 \\ \mathrm{BB} & 12 \\ \mathrm{BB}- & 13 \\ \mathrm{~B}+ & 14 \\ \mathrm{~B} & 15 \\ \mathrm{~B}- & 16 \\ \mathrm{CCC}+ & 17 \\ \mathrm{CC} & 18 \\ \mathrm{D} & 19\end{array}$

- Bond Yield Spread is the bond's yield to maturity minus the yield to maturity on a Treasury security with a closest time to maturity. To compute a bond's yield to maturity, I first identify a bond transaction date that is closest to the firm's fiscal year end. I then calculate the yield to maturity for every bond transaction price on that date. If there are multiple transactions for a given bond in a given day, I calculate a daily value-weighted average yield spread using the par amounts of each transaction as weights.

Firm Performance Variables:

- Operating Return on Assets $(\mathrm{OROA})$ is the ratio of operating income before deprecation and amortization (Compustat item $18+$ Compustat item 14) divided by total assets (Compustat item 6).

- Tobin's Q is defined as total assets (Compustat item 6) plus the market value of shareholders' equity (Compustat item $25^{*}$ Compustat item 199) subtract the book value of shareholders' equity (Compustat item 60) divided by total assets (Compustat item 6). 
- Annual Stock Return is computed as the closing price at the end of the year (Compustat item 199) divided by the closing price at the end of the previous year subtracts one.

- Return on Equity is computed as income available to common shareholders divided by book equity (Compustat item 60). Income available to common shareholders $=$ Income before extraordinary items (Compustat item 18) - Preferred dividends (Compustat item 19) + Deferred Taxes (Compustat item 50) if available.

- Sales growth is computed as current year's sales divided by last year's sales less one.

- Industry median adjusted performances are computed as the firm's performance measures subtract the corresponding industry medians. Industry classification is based on 48 Fama and French industries described in Fama and French (1997).

\section{Other Firm Variables:}

- Firm Age is the total number of years since the firm was founded. I obtain Firm Age from the Corporate Library database and fill the missing data by searching on the internet.

- Firm Size is the natural log of total sales (Compustat item 12).

- Activist Institutional Ownership is the ownership of the 18 activist institutional shareholders listed in Cremers and Nair (2005).

- Pay directors equity-based compensation $(0 / 1)$ equals one if the firm pays director equitybased compensation and zero otherwise.

- Capital Intensity is measured as the net value of property, plant and equipment (Compustat Item 8) divided by total assets (Compustat Item 6). 
- Surplus Cash is computed as cash from assets-in-place to total assets. Cash from assetsin-place is measured as net cash flow from operating activities (Compustat Item 308) subtracts depreciation and amortization (Compustat Item 125) plus R\&D expense (Compustat Item 46).

- Depreciation Ratio is defined as depreciation (Compustat Item 14) over total assets (Compustat Item 6).

\section{Industry Variables:}

- Industry Homogeneity is computed as in Parrino (1997). First, I create an equally weighted return index for the 2-digit SIC industry using CRSP monthly returns and regress the monthly return for each firm in the index on the equally weighted market index and industry index. Then, I take the partial correlation coefficient for the industry return index and average it across all firms in the industry to obtain the industry homogeneity proxy. I require a minimum of 20 firms in a 2-digit SIC code.

- Industry Concentration (Herfindahl Index) is defined as the sum of squared market share of each firm in that industry. Industry classification is based on 48 Fama and French industries described in Fama and French (1997).

All industry level variables are computed on the basis of all Compustat firms. 
Figure 1. Industry Distribution and the Number of Employers

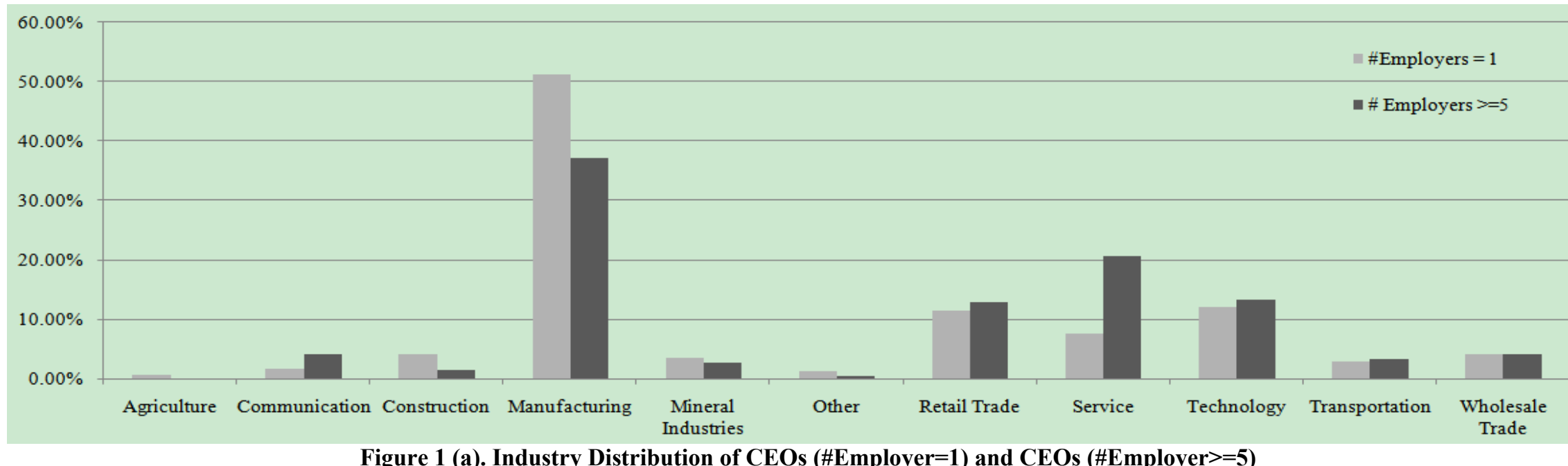

This graph presents how CEOs that have worked for one employer and CEOs that have worked for at least five employers distribute across different industries.

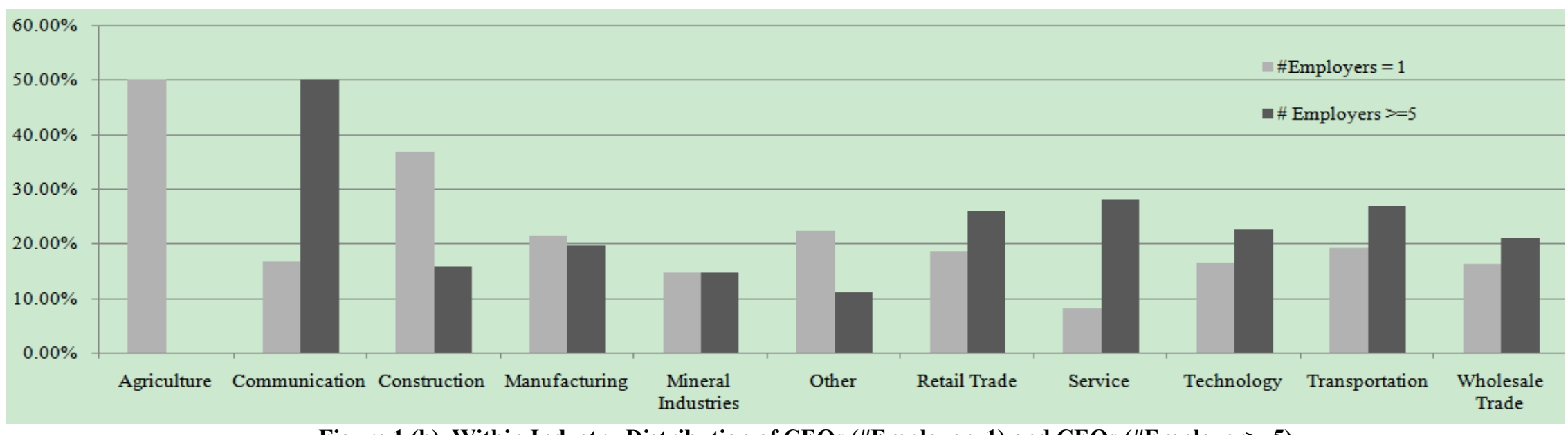

Figure 1 (b). Within Industry Distribution of CEOs (\#Employer=1) and CEOs (\#Employer>=5)

This graph presents, within each industry, the percentage of CEOs that have worked for one employer and the percentage of CEOs that have worked for at least five employers. 
Figure 2. Time Panel Distribution and the Number of Employers

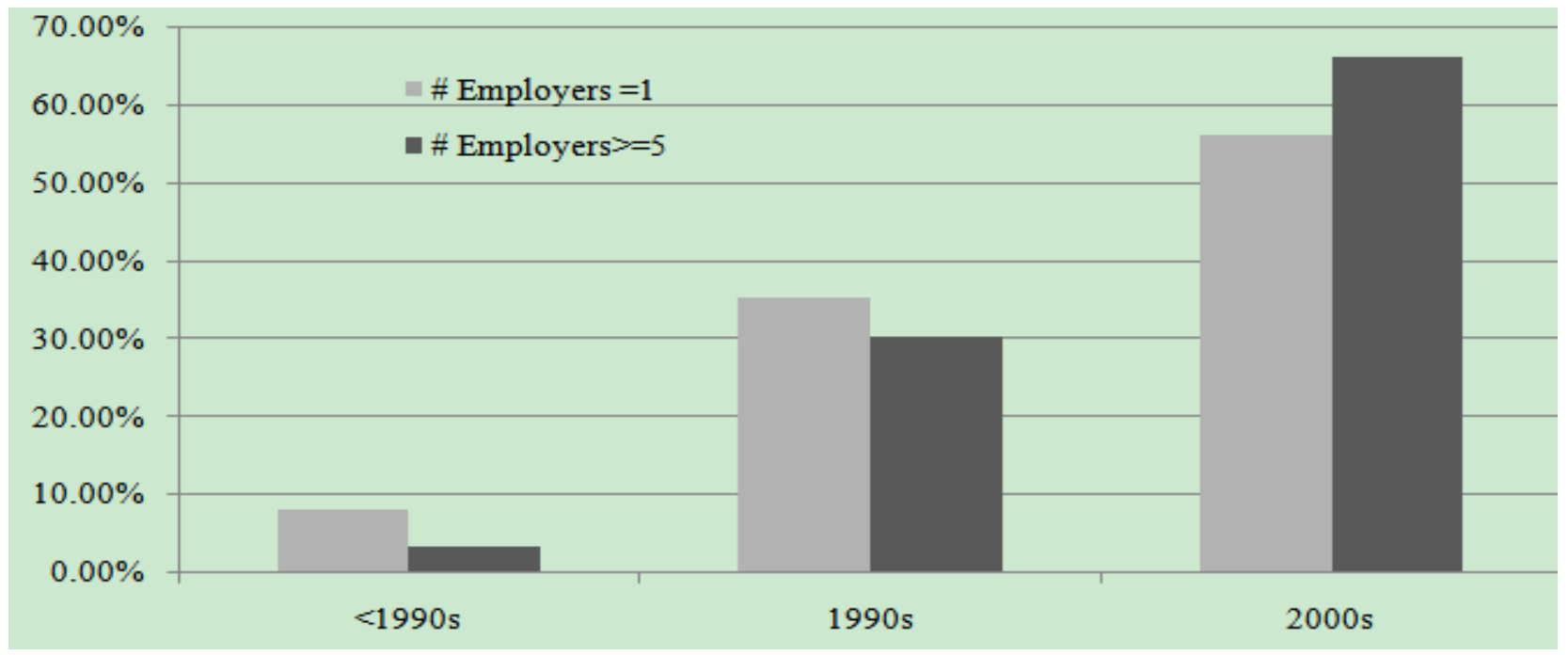

Figure 2 (a). Time Panel Distribution of CEOs (\#Employer=1) and CEOs (\#Employer>=5)

This graph presents how CEOs that have worked for one employer and CEOs that have worked for at least five employers distribute across different time panels.

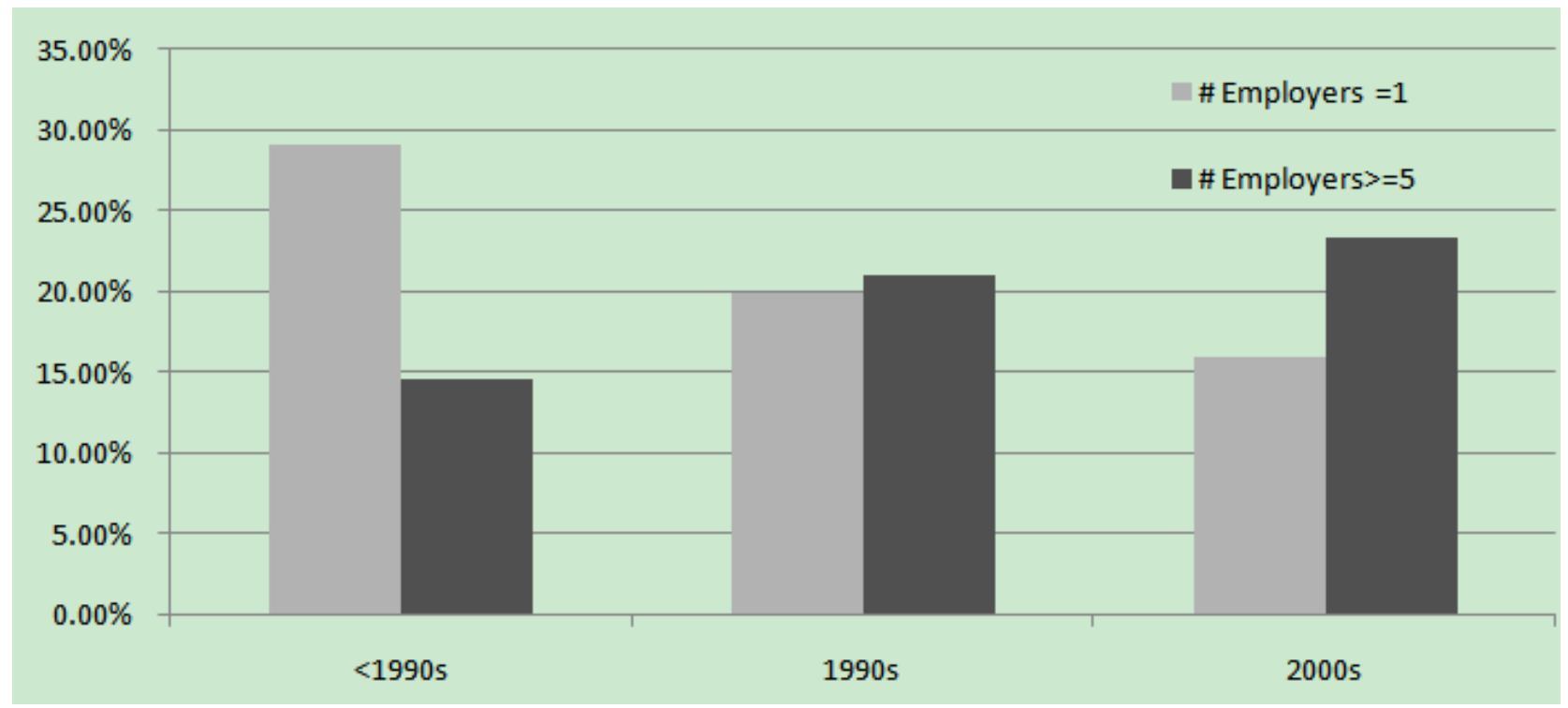

Figure 2 (b). Within Time Panel Distribution of CEOs (\#Employer=1) and CEOs (\#Employer>=5)

This graph presents, within each time panel, the percentage of CEOs that have worked for one employer and the percentage of CEOs that have worked for at least five employers. 


\section{Table 1. Summary Statistics}

This table presents summary statistics for CEO characteristic of 1,144 CEOs as of 2005. Details for sample selection are in Section 3. \#Employers is the number of employers the CEO has worked for since his first full-time job. \#Employers per year is the number of employers the CEO has worked for divided by the CEO's career length. Employer Change Recency is measured as the sum of distance of each employer change to the current employment. Firm (Industry) Experience diversification is measured as the sum of squared career shares of each firm (industry) for which the CEO has worked. The career share of every firm (industry) is computed as the number of years the CEO has worked for the firm (industry) divided by the CEO's career length. Founder dummy equals one if the CEO is the founder or from the founder's family. CEO tenure is the number of years the person has been the CEO for the current firm. \#Functional Areas is the number of functional areas the CEO had worked in before becoming CEO of the current firm. Finance dummy equals one if the CEO has worked in the finance area before becoming CEO.

Panel A: CEO Characteristics

\begin{tabular}{lcccccc}
\hline Variables & Obs. & Mean & Median & Maximum & Minimum & Std. \\
\hline CEO Employment History Proxies & & & & & & \\
\# Employers & 1,144 & 3.225 & 3.000 & 11.000 & 1.000 & 1.818 \\
\# Employer Changes per year & 1,144 & 0.106 & 0.094 & 0.385 & 0.020 & 0.062 \\
Employer Change Recency & 1,144 & 1.129 & 0.833 & 6.765 & 0.000 & 1.096 \\
Firm Experience Diversification & 1,144 & 0.555 & 0.506 & 1.000 & 0.104 & 0.257 \\
Industry Experience Diversification & 1,144 & 0.708 & 0.702 & 1.000 & 0.145 & 0.254 \\
& & & & & & \\
CEO Characteristics & & & & & & \\
\# Funcational Areas & 1,144 & 2.782 & 3 & 5 & & 0.980 \\
MBA (0/1)(\%) & 1,144 & $35.58 \%$ & & & & \\
Founder (0/1)(\%) & 1,144 & $18.62 \%$ & & & & \\
Has Finance Background (0/1)(\%) & 1,144 & $22.90 \%$ & & & & \\
CEO Age & 1,144 & 55.613 & 56 & 90 & 36 & 7.915 \\
CEO Tenure & 1,144 & 7.698 & 5 & 54 & 0 & \\
\hline
\end{tabular}

Panel B: Comparison of CEO Characteristics for CEOs that have worked for different numbers of employers

\begin{tabular}{|c|c|c|c|c|c|c|c|c|c|c|}
\hline & \multirow{2}{*}{\multicolumn{2}{|c|}{$\begin{array}{c}\text { Q1 } \\
\text { \# Employers=1 }\end{array}$}} & \multirow{2}{*}{\multicolumn{2}{|c|}{$\begin{array}{c}\text { Q2 } \\
\# \text { Employers }=2\end{array}$}} & \multirow{2}{*}{\multicolumn{2}{|c|}{$\begin{array}{c}\text { Q3 } \\
\text { \# Employers }=3,4\end{array}$}} & \multicolumn{2}{|c|}{ Q4 } & \multirow{2}{*}{\multicolumn{2}{|c|}{ Q4-Q1 }} \\
\hline & & & & & & & \# Emplc & yers $>4$ & & \\
\hline & Mean & Med. & Mean & Med. & Mean & Med. & Mean & Med. & Mean & Med. \\
\hline MBA $(0 / 1)(\%)$ & $26.92 \%$ & & $34.95 \%$ & & $35.70 \%$ & & $42.25 \%$ & & $15.32 \% * * *$ & \\
\hline Founder $(0 / 1)(\%)$ & $29.12 \%$ & & $22.01 \%$ & & $16.71 \%$ & & $10.08 \%$ & & $-19.04 \% * * *$ & \\
\hline $\begin{array}{l}\text { Has Fin. Bkgd. } \\
(0 / 1)(\%)\end{array}$ & $17.03 \%$ & & $24.92 \%$ & & $21.27 \%$ & & $27.13 \%$ & & $10.10 \% * *$ & \\
\hline \# Functional Areas & 2.473 & 3 & 2.650 & 3 & 2.828 & 3 & 3.089 & 3 & $0.617 * * *$ & $0^{* * *}$ \\
\hline CEO Age & 55.604 & 55 & 55.437 & 56 & 55.177 & 55 & 56.628 & 56 & 1.024 & 1 \\
\hline CEO Tenure & 8.967 & 6 & 9.578 & 7 & 8.733 & 6 & 7.574 & 5.5 & $-1.393 *$ & $-1.5^{* *}$ \\
\hline
\end{tabular}




\section{Table 2. Summary Statistics for Firm Policies in the Year Prior to CEO Turnover}

This table presents summary statistics for 714 CEOs and their firm policies in the year prior to the year of CEO turnover. Details for sample selection are in Section 4.1. \#Employers is the number of employers the CEO has worked for since his first full-time job. \#Employers per year is the number of employers the CEO has worked for divided by the CEO's career length. Employer Change Recency is measured as the sum of squared distance of each employer change to the current employment. Firm (Industry) Experience diversification is measured as the sum of squared career shares of each firm (industry) for which the CEO has worked. The career share of every firm (industry) is computed as the number of years the CEO has worked for the firm (industry) divided by the CEO's career length. Prior CEO tenure is the number of years the prior CEO has been the CEO for the firm. Prior CEO Is Chairman (0/1) dummy equals one if the prior CEO was also the chairman of the boar. Board Size is the number of board directors in the firm. Board Insiders (\%) is the percentage of insiders in the board. Positive (Negative) Industry Shock dummy equals one if the total sales in the firm's industry increase (decrease) $10 \%$ or more. Positive (Negative) Firm Shock dummy equals one if the firm's sales growth is 10\% more (less) than the industry's median sales growth. See Appendix A for firm and industry level variable definitions.

\begin{tabular}{lcccccc}
\hline Variables & Obs. & Mean & Median & Maximum & Minimum & Std. \\
\hline Prior CEO Characteristics & & & & & & \\
Prior CEO Tenure & 714 & 8.926 & 7 & 50 & 0 & 8.602 \\
Prior CEO Is Chairman (0/1) (\%) & 714 & $74.93 \%$ & & & & \\
Forced Turnover (0/1) (\%) & 714 & $13.59 \%$ & & & & \\
& & & & & & \\
Current CEO Employment History in the year of Turnover & & & & \\
\# Employers & 714 & 3.190 & 3 & 11 & 1 & 0.016 \\
\# Employer Changes per year & 714 & 0.121 & 0.108 & 0.417 & 0.023 & 0.070 \\
Employer Change Recency & 714 & 1.308 & 1.000 & 6.935 & 0.104 & 0.264 \\
Firm Experience Diversification & 714 & 0.569 & 0.513 & 1 & 0.157 & 0.256 \\
Industry Experience Diversification & 714 & 0.706 & 0.692 & 1 & 0.157 \\
& & & & & & \\
Firm Policies in the year prior to CEO turnover & & & & & \\
Leverage & 714 & 0.194 & 0.153 & 0.768 & 0.000 & 0.183 \\
R\&D Expenditures/Total Assets & 714 & 0.030 & 0.005 & 0.250 & 0.000 & 0.048 \\
Advertising/Total Assets & 714 & 0.013 & 0.000 & 0.170 & 0.000 & 0.030 \\
Capital Expenditure & 706 & 0.058 & 0.046 & 0.287 & 0.004 & 0.048 \\
Total Risk (Daily Stock Return Std.) & 714 & 0.452 & 0.404 & 1.098 & 0.153 & 0.191 \\
Firm Specific Risk (CAPM) & 714 & 0.410 & 0.366 & 1.007 & 0.133 & 0.177 \\
Firm Specific Risk (Four Factor) & 714 & 0.395 & 0.351 & 1.096 & 0.103 & 0.171 \\
Market Risk (CAPM) & 714 & 0.989 & 0.897 & 2.674 & 0.033 & 0.556 \\
& & & & & & \\
Other Firm Control Variables in the year prior to CEO turnover & & & & \\
In(Sales) & 714 & 7.457 & 7.330 & 12.170 & 2.622 & 1.507 \\
Firm Age & 714 & 57.122 & 47 & 164 & 3 & 39.252 \\
Herfindhal Index & 714 & 0.064 & 0.045 & 0.830 & 0.011 & 0.080 \\
Industry Homogeneity & 694 & 0.193 & 0.169 & 0.488 & 0.075 & 0.088 \\
Activist Institutional Holding & 714 & 0.029 & 0.026 & 0.092 & 0.000 & 0.014 \\
Pay director equity based & & & & & & \\
compensation (0/1) (\%) & 714 & $79.97 \%$ & & & & \\
Board Size & 714 & 9.496 & 9 & 26 & 4 & 2.695 \\
Board Insiders (\%) & 714 & $26.20 \%$ & $23.08 \%$ & $88.89 \%$ & $0.00 \%$ & $13.66 \%$ \\
\hline
\end{tabular}


Table 2 Continued.

\begin{tabular}{|c|c|c|c|c|c|c|}
\hline Variables & Obs. & Mean & Median & Maximum & Minimum & Std. \\
\hline CEO Compensation Delta (M\$) & 714 & 0.576 & 0.211 & 6.394 & 0.000 & 1.069 \\
\hline CEO Compensation Vega (M\$) & 714 & 0.238 & 0.086 & 2.497 & 0.000 & 0.416 \\
\hline CEO Cash Compensation & 714 & 0.627 & 0.687 & 1.000 & 0.021 & 0.323 \\
\hline Operating Return on Assets (OROA) & 714 & 0.090 & 0.096 & 0.316 & -0.332 & 0.091 \\
\hline Industry Median Adjusted OROA & 714 & 0.059 & 0.044 & 0.457 & -0.332 & 0.114 \\
\hline Annual Stock Return (RET) & 714 & 0.042 & 0.003 & 2.046 & -0.729 & 0.460 \\
\hline Ind. Med. Adj. Annual Stock Return & 714 & 0.047 & -0.006 & 1.974 & -0.708 & 0.440 \\
\hline Tobin's Q & 714 & 2.125 & 1.617 & 8.727 & 0.785 & 1.503 \\
\hline Industry Adjusted Tobin's Q & 714 & 0.540 & 0.155 & 6.671 & -1.470 & 1.387 \\
\hline Positive Industry Shock (0/1) (\%) & 714 & $36.69 \%$ & & & & \\
\hline Negative Industry Shock (0/1) (\%) & 714 & $7.14 \%$ & & & & \\
\hline Positive Firm Shock (\%) & 714 & $20.31 \%$ & & & & \\
\hline Negative Firm Shock (\%) & 714 & $22.13 \%$ & & & & \\
\hline
\end{tabular}




\section{Table 3. Differences in Pre-turnover Firm Policies for CEOs that have worked for different numbers of employers}

This table presents differences in prior CEO characteristics and firm policies in the year prior to the year of CEO turnover for 714 CEOs in the CEO-firm match analysis. Refer to Tables 1 and 2 and Appendix A for variable definitions. Q1 includes CEOs in the bottom quartile and Q4 includes CEOs in the top quartile. Q4-Q1 is the difference in means (medians) between the top and the bottom quartiles. The differences in means and medians for the bottom and top quartiles are presented at the right side of the table. The statistical significance for difference in means is based on t-test and for difference in medians is based on the nonparametric signed rank test. $* * *, * *$, and $*$ indicate significance at the 1,5 , and $10 \%$ levels, respectively.

\begin{tabular}{|c|c|c|c|c|c|c|c|c|c|c|c|c|}
\hline \multirow{3}{*}{ Prior CEO Characteristics } & \multicolumn{2}{|c|}{ \# Employers $=1$} & \multicolumn{2}{|c|}{ \# Employers $=2$} & \multicolumn{2}{|c|}{ \# Employers $=3,4$} & \multicolumn{2}{|c|}{ \# Employers $>=5$} & \multicolumn{4}{|c|}{ Q4-Q1 } \\
\hline & \multirow[t]{2}{*}{ Mean } & \multirow[t]{2}{*}{ Median } & \multirow[t]{2}{*}{ Mean } & \multirow[t]{2}{*}{ Median } & \multirow[t]{2}{*}{ Mean } & \multirow[t]{2}{*}{ Median } & \multirow[t]{2}{*}{ Mean } & \multirow[t]{2}{*}{ Median } & \multirow[t]{2}{*}{ Mean } & \multicolumn{3}{|c|}{ Median } \\
\hline & & & & & & & & & & & & \\
\hline Prior CEO Tenure & 11.455 & 7 & 9.973 & 8 & 8.221 & 7 & 6.851 & 5 & -4.604 & $* *$ & -2 & $* *$ \\
\hline Prior CEO Is Chairman & $80.49 \%$ & & $80.65 \%$ & & $70.49 \%$ & & $70.81 \%$ & & $-9.68 \%$ & $*$ & & \\
\hline $\begin{array}{l}\text { Forced Turnover } \\
\text { Board Characteristics }\end{array}$ & $5.69 \%$ & & $8.60 \%$ & & $15.16 \%$ & & $22.98 \%$ & & $17.29 \%$ & $* *$ & & \\
\hline Board Insiders (\%) & $27.19 \%$ & $25.00 \%$ & $26.06 \%$ & $23.08 \%$ & $26.93 \%$ & $25.00 \%$ & $24.50 \%$ & $20.00 \%$ & $-2.68 \%$ & * & $-5.00 \%$ & $*$ \\
\hline Board Size & 10.894 & 11 & 9.651 & 9 & 9.029 & 9 & 8.957 & 9 & -1.938 & $* *$ & -2 & $* *$ \\
\hline Firm Characteristics & & & & & & & & & & & & \\
\hline Firm Size & 7.989 & 7.838 & 7.556 & 7.467 & 7.145 & 7.044 & 7.153 & 6.871 & -0.835 & $* * *$ & -0.967 & $* *$ \\
\hline Firm Age & 75.724 & 79 & 54.097 & 44 & 53.082 & 40.5 & 52.528 & 40 & -23.196 & $* *$ & -39 & $* *$ \\
\hline Leverage & 0.214 & 0.173 & 0.171 & 0.113 & 0.206 & 0.177 & 0.189 & 0.149 & -0.026 & & -0.024 & $* *$ \\
\hline R\&D Exp./Total Assets & 0.020 & 0.004 & 0.031 & 0.007 & 0.031 & 0.006 & 0.036 & 0.003 & 0.016 & $* * *$ & 0.000 & \\
\hline Advertising/Total Assets & 0.013 & 0.000 & 0.011 & 0.000 & 0.010 & 0.000 & 0.017 & 0.000 & 0.004 & & 0.000 & \\
\hline Capital Expenditure & 0.063 & 0.051 & 0.061 & 0.048 & 0.057 & 0.043 & 0.055 & 0.042 & -0.008 & & -0.009 & $* *$ \\
\hline Operating Return on Assets & 0.099 & 0.102 & 0.111 & 0.111 & 0.084 & 0.090 & 0.069 & 0.090 & -0.031 & $* * *$ & -0.012 & $* *$ \\
\hline Industry Adjusted OROA & 0.054 & 0.035 & 0.077 & 0.054 & 0.057 & 0.042 & 0.045 & 0.038 & -0.009 & & 0.003 & \\
\hline Annual Stock Return & 0.045 & 0.044 & 0.098 & 0.052 & 0.040 & -0.040 & -0.022 & -0.053 & -0.068 & & -0.097 & $* *$ \\
\hline $\begin{array}{l}\text { Ind. Med. Adj. Ann. Stock. Ret. } \\
\text { Firm Risk Measures }\end{array}$ & 0.064 & 0.035 & 0.076 & 0.036 & 0.046 & -0.033 & 0.000 & -0.075 & -0.064 & & -0.111 & $* *$ \\
\hline$\overline{\text { Total Risk (Daily Stock Std.) }}$ & 0.374 & 0.346 & 0.429 & 0.387 & 0.477 & 0.435 & 0.501 & 0.450 & 0.128 & $* * *$ & 0.104 & $* *$ \\
\hline Market Risk & 0.807 & 0.769 & 1.000 & 0.917 & 0.997 & 0.906 & 1.103 & 0.980 & 0.296 & $* * *$ & 0.211 & $* *$ \\
\hline Firm Specific Risk (CAPM) & 0.339 & 0.314 & 0.385 & 0.357 & 0.436 & 0.386 & 0.452 & 0.399 & 0.113 & $* * *$ & 0.085 & $* *$ \\
\hline $\begin{array}{l}\text { Firm Specific Risk (4 Factors) } \\
\text { Shocks }\end{array}$ & 0.328 & 0.305 & 0.371 & 0.338 & 0.420 & 0.373 & 0.437 & 0.382 & 0.110 & $* * *$ & 0.077 & $* *$ \\
\hline 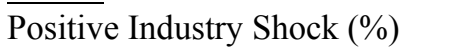 & $33.33 \%$ & & $39.78 \%$ & & $40.57 \%$ & & $29.81 \%$ & & $-3.52 \%$ & & & \\
\hline Negative Industry Shock (\%) & $7.32 \%$ & & $7.53 \%$ & & $6.97 \%$ & & $6.83 \%$ & & $-0.48 \%$ & & & \\
\hline Industry Shocks (0/1) (\%) & $40.65 \%$ & & $47.31 \%$ & & $47.54 \%$ & & $36.65 \%$ & & $-4.00 \%$ & & & \\
\hline Positive Firm Shock (0/1) (\%) & $16.26 \%$ & & $18.82 \%$ & & $22.54 \%$ & & $21.74 \%$ & & $5.48 \%$ & & & \\
\hline Negative Firm Shock (0/1) (\%) & $14.63 \%$ & & $19.89 \%$ & & $22.54 \%$ & & $29.81 \%$ & & $15.18 \%$ & $* *$ & & \\
\hline Firm Shocks $(0 / 1)(\%)$ & $30.89 \%$ & & $38.71 \%$ & & $45.08 \%$ & & $51.55 \%$ & & $20.66 \%$ & $* *$ & & \\
\hline
\end{tabular}




\section{Table 4. The CEO-Firm Match}

This table presents OLS results for the CEO-firm match for 714 CEO turnovers. Details for the CEO turnover sample are in Section 4.1. The dependent variables are listed at the top of each column. Refer to Tables 1 and 2 and Appendix A for variable definitions. I report $p$-values based on robust standard errors clustered at the firm level in parenthesis. ${ }^{* *},{ }^{* *}$, and $*$ indicate significance at the 1,5 , and $10 \%$ levels, respectively.

\begin{tabular}{|c|c|c|c|c|c|}
\hline & \# Employers & $\begin{array}{l}\text { \# Employer } \\
\text { Changes } \\
\text { per year }\end{array}$ & $\begin{array}{c}\text { Firm } \\
\text { Experience } \\
\text { Recency }\end{array}$ & $\begin{array}{c}\text { Firm } \\
\text { Experience } \\
\text { Diversification }\end{array}$ & $\begin{array}{c}\text { Industry } \\
\text { Experience } \\
\text { Diversification }\end{array}$ \\
\hline \multicolumn{6}{|c|}{ Firm Characteristics in the year prior to CEO turnover } \\
\hline Total Risk (Daily Stock & $1.491 * * *$ & $\overline{0.050 * * *}$ & $1.008 * * *$ & -0.070 & -0.034 \\
\hline Return Std.) & $(0.002)$ & $(0.006)$ & $(0.002)$ & $(0.333)$ & $(0.635)$ \\
\hline Leverage & $\begin{array}{l}-0.007 \\
(0.987)\end{array}$ & $\begin{array}{c}0.002 \\
(0.892)\end{array}$ & $\begin{array}{c}0.071 \\
(0.804)\end{array}$ & $\begin{array}{l}-0.001 \\
(0.989)\end{array}$ & $\begin{array}{c}0.022 \\
(0.731)\end{array}$ \\
\hline $\ln$ (Total Sales) & $\begin{array}{c}-0.163 * * * \\
(0.009)\end{array}$ & $\begin{array}{c}-0.008 * * * \\
(0.001)\end{array}$ & $\begin{array}{l}-0.077^{*} \\
(0.061)\end{array}$ & $\begin{array}{c}0.026 * * * \\
(0.005)\end{array}$ & $\begin{array}{c}0.014 \\
(0.119)\end{array}$ \\
\hline Ln(Firm Age) & $\begin{array}{l}-0.138 \\
(0.156)\end{array}$ & $\begin{array}{l}-0.006^{*} \\
(0.086)\end{array}$ & $\begin{array}{c}-0.148 * * \\
(0.021)\end{array}$ & $\begin{array}{c}0.043 * * * \\
(0.003)\end{array}$ & $\begin{array}{c}0.024 \\
(0.103)\end{array}$ \\
\hline Ind. Median Adjusted OROA & $\begin{array}{l}-0.281 \\
(0.667)\end{array}$ & $\begin{array}{l}-0.012 \\
(0.624)\end{array}$ & $\begin{array}{l}-0.359 \\
(0.404)\end{array}$ & $\begin{array}{c}0.029 \\
(0.768)\end{array}$ & $\begin{array}{c}0.125 \\
(0.197)\end{array}$ \\
\hline Ind. Median Adj. Stock Ret. & $\begin{array}{l}-0.122 \\
(0.430)\end{array}$ & $\begin{array}{l}-0.004 \\
(0.452)\end{array}$ & $\begin{array}{c}-0.227 * * \\
(0.026)\end{array}$ & $\begin{array}{c}0.003 \\
(0.890)\end{array}$ & $\begin{array}{c}0.037 \\
(0.102)\end{array}$ \\
\hline Tobin's Q & $\begin{array}{c}0.019 \\
(0.745)\end{array}$ & $\begin{array}{c}0.000 \\
(0.880)\end{array}$ & $\begin{array}{c}0.008 \\
(0.828)\end{array}$ & $\begin{array}{l}-0.006 \\
(0.519)\end{array}$ & $\begin{array}{l}-0.007 \\
(0.419)\end{array}$ \\
\hline R\&D Exp./Total Assets & $\begin{array}{c}-3.174 * * \\
(0.045)\end{array}$ & $\begin{array}{l}-0.109^{*} \\
(0.065)\end{array}$ & $\begin{array}{l}-1.865^{*} \\
(0.073)\end{array}$ & $\begin{array}{c}0.590 * * \\
(0.012)\end{array}$ & $\begin{array}{c}0.295 \\
(0.208)\end{array}$ \\
\hline CEO Cash Compensation & $\begin{array}{c}0.164 \\
(0.437)\end{array}$ & $\begin{array}{c}0.001 \\
(0.916)\end{array}$ & $\begin{array}{c}0.203 \\
(0.145)\end{array}$ & $\begin{array}{l}-0.006 \\
(0.836)\end{array}$ & $\begin{array}{l}-0.026 \\
(0.412)\end{array}$ \\
\hline Compensation Delta & $\begin{array}{c}0.088 \\
(0.301)\end{array}$ & $\begin{array}{c}0.004 \\
(0.233)\end{array}$ & $\begin{array}{c}0.046 \\
(0.416)\end{array}$ & $\begin{array}{c}-0.012 \\
(0.355)\end{array}$ & $\begin{array}{c}-0.014 \\
(0.268)\end{array}$ \\
\hline Compensation Vega & $\begin{array}{c}-0.054 \\
(0.818)\end{array}$ & $\begin{array}{c}0.001 \\
(0.950)\end{array}$ & $\begin{array}{c}-0.075 \\
(0.624)\end{array}$ & $\begin{array}{c}-0.006 \\
(0.852)\end{array}$ & $\begin{array}{c}-0.009 \\
(0.793)\end{array}$ \\
\hline Herfindhal Index & $\begin{array}{l}-0.596 \\
(0.457)\end{array}$ & $\begin{array}{c}-0.017 \\
(0.567)\end{array}$ & $\begin{array}{l}-0.121 \\
(0.819)\end{array}$ & $\begin{array}{l}0.202^{*} \\
(0.090)\end{array}$ & $\begin{array}{l}-0.045 \\
(0.708)\end{array}$ \\
\hline Negative Ind. Shocks (0/1) & $\begin{array}{c}0.234 \\
(0.235)\end{array}$ & $\begin{array}{c}0.009 \\
(0.225)\end{array}$ & $\begin{array}{c}0.110 \\
(0.397)\end{array}$ & $\begin{array}{c}-0.038 \\
(0.193)\end{array}$ & $\begin{array}{l}-0.056^{*} \\
(0.056)\end{array}$ \\
\hline \multicolumn{6}{|c|}{ Board Characteristics at the year prior to CEO turnover } \\
\hline Board Size & $\begin{array}{c}-0.071 * * \\
(0.023)\end{array}$ & $\begin{array}{l}-0.002 * \\
(0.053)\end{array}$ & $\begin{array}{c}-0.056^{* * *} \\
(0.007)\end{array}$ & $\begin{array}{c}0.015 * * * \\
(0.001)\end{array}$ & $\begin{array}{c}0.014 * * * \\
(0.002)\end{array}$ \\
\hline Pay directors equity based & $\begin{array}{c}0.195 \\
(0.252)\end{array}$ & $\begin{array}{c}0.008 \\
(0.192)\end{array}$ & $\begin{array}{c}0.071 \\
(0.527)\end{array}$ & $\begin{array}{l}-0.031 \\
(0.215)\end{array}$ & $\begin{array}{l}-0.017 \\
(0.492)\end{array}$ \\
\hline Insider Directors (\%) & $\begin{array}{c}-1.259 * * \\
(0.019)\end{array}$ & $\begin{array}{l}-0.038^{*} \\
(0.060)\end{array}$ & $\begin{array}{c}-1.152^{* * *} \\
(0.001)\end{array}$ & $\begin{array}{l}0.151^{*} \\
(0.057)\end{array}$ & $\begin{array}{c}0.239 * * * \\
(0.002)\end{array}$ \\
\hline Act. Institutional Holding (\%) & $\begin{array}{l}-6.760 \\
(0.176)\end{array}$ & $\begin{array}{l}-0.259 \\
(0.163)\end{array}$ & $\begin{array}{l}-3.395 \\
(0.303)\end{array}$ & $\begin{array}{l}1.342^{*} \\
(0.068)\end{array}$ & $\begin{array}{c}0.894 \\
(0.223)\end{array}$ \\
\hline \multicolumn{6}{|l|}{ Prior CEO Characteristics } \\
\hline Prior CEO is Chairman $(0 / 1)$ & $\begin{array}{l}-0.112 \\
(0.472)\end{array}$ & $\begin{array}{l}-0.004 \\
(0.489)\end{array}$ & $\begin{array}{l}-0.058 \\
(0.569)\end{array}$ & $\begin{array}{c}-0.007 \\
(0.760)\end{array}$ & $\begin{array}{c}0.011 \\
(0.637)\end{array}$ \\
\hline Prior CEO Tenure & $\begin{array}{l}-0.015^{*} \\
(0.074)\end{array}$ & $\begin{array}{l}-0.001 * \\
(0.084)\end{array}$ & $\begin{array}{c}-0.012 * * \\
(0.035)\end{array}$ & $\begin{array}{c}0.002 \\
(0.129)\end{array}$ & $\begin{array}{c}0.002 \\
(0.117)\end{array}$ \\
\hline Forced Turnover $(0 / 1)$ & $\begin{array}{c}0.689 * * * \\
(0.000)\end{array}$ & $\begin{array}{c}0.024 * * * \\
(0.001)\end{array}$ & $\begin{array}{c}0.503 * * * \\
(0.000)\end{array}$ & $\begin{array}{c}-0.033 \\
(0.241)\end{array}$ & $\begin{array}{c}0.002 \\
(0.952)\end{array}$ \\
\hline
\end{tabular}


Table 4 Continued.

\begin{tabular}{lccccc} 
Current CEO Characteristics & & & & & \\
CEO Age & $1.990^{* * *}$ & $-0.128^{* * *}$ & $1.150^{* * *}$ & $-0.230^{* * *}$ & $-0.195^{* * *}$ \\
& $(0.000)$ & $(0.000)$ & $(0.000)$ & $(0.002)$ & $(0.008)$ \\
MBA (0/1) & $0.230^{*}$ & $0.010^{* *}$ & $0.148^{*}$ & $-0.034^{*}$ & $-0.034^{*}$ \\
& $(0.077)$ & $(0.031)$ & $(0.084)$ & $(0.075)$ & $(0.079)$ \\
Founder (0/1) & $-0.705^{* * *}$ & $-0.028^{* * *}$ & $-0.575^{* * *}$ & $0.128^{* * *}$ & 0.060 \\
& $(0.006)$ & $(0.003)$ & $(0.001)$ & $(0.001)$ & $(0.117)$ \\
\# Functional Areas & $0.266^{* * *}$ & $0.009^{* * *}$ & $0.126^{* * *}$ & $-0.031^{* * *}$ & $-0.031^{* * *}$ \\
& $(0.000)$ & $(0.001)$ & $(0.005)$ & $(0.002)$ & $(0.002)$ \\
Has Finance Background (0/1) & $0.291^{* *}$ & $0.010^{*}$ & 0.103 & $-0.060^{* * *}$ & $-0.102^{* * *}$ \\
& $(0.049)$ & $(0.061)$ & $(0.290)$ & $(0.006)$ & $(0.000)$ \\
Constant & -3.278 & $0.674^{* * *}$ & -2.080 & $1.087^{* * *}$ & $1.159^{* * *}$ \\
& $(0.118)$ & $(0.000)$ & $(0.132)$ & $(0.001)$ & $(0.000)$ \\
Year Dummies & Yes & Yes & Yes & Yes & Yes \\
Industry Dummies & Yes & Yes & Yes & Yes & Yes \\
Observations & 714 & 714 & 714 & 714 & 714 \\
R-squared & 0.229 & 0.272 & 0.245 & 0.200 & 0.157 \\
\hline
\end{tabular}




\section{Table 5. Summary Statistics for Post-turnover Firm Characteristics}

This table presents summary statistics for CEO and firm characteristic of 917 CEOs and 5,139 post-turnover firm years from 1992 to 2007. Details for sample selection are in Section 3. \#Employers is the number of employers the CEO has worked for since his first full-time job. \#Employers per year is the number of employers the CEO has worked for divided by the CEO's career length. Employer Change Recency is measured as the sum of squared distance of each employer change to the current employment. Firm (Industry) Experience diversification is measured as the sum of squared career shares of each firm (industry) for which the CEO has worked. The career share of every firm (industry) is computed as the number of years the CEO has worked for the firm (industry) divided by the CEO's career length. CEO tenure is the number of years the person has been the CEO for the current firm. Panel A presents summary statistics for CEO characteristics and Panel B presents summary statistics for firm characteristics. Panel C presents the correlations between the five CEO employment history proxies. See Appendix A for firm and industry level variable definitions. All firm-level variables are winsorized at the $1 \%$ and $99 \%$ levels.

Panel A: CEO Characteristics

\begin{tabular}{lcccccc}
\hline Variables & Obs. & Mean & Median & Maximum & Minimum & Std. \\
\hline CEO Employment History Proxies & & & & & & \\
\# Employers & 5,139 & 2.981 & 3 & 11 & 1 & 1.772 \\
\# Employer Changes per year & 5,139 & 0.100 & 0.087 & 0.400 & 0.021 & 0.060 \\
Employer Change Recency & 5,139 & 1.017 & 0.724 & 6.875 & 0.000 & 1.065 \\
Firm Experience Diversification & 5,139 & 0.580 & 0.528 & 1.000 & 0.099 & 0.272 \\
Industry Experience Diversification & 5,139 & 0.715 & 0.715 & 1.000 & 0.144 & 0.257 \\
& & & & & & \\
CEO Characteristics & & & & & & \\
\# Functional Areas & 5,139 & 2.728 & 3 & 5 & & 0.945 \\
MBA (0/1)(\%) & 5,139 & $36.31 \%$ & & & & \\
Founder (0/1)(\%) & 5,139 & $13.87 \%$ & & & & \\
Has Finance Background (0/1)(\%) & 5,139 & $24.30 \%$ & & & & \\
CEO Age & 5,139 & 53.845 & 54 & 87 & 34 & 6.888 \\
CEO Tenure & 5,139 & 5.766 & 4 & 44 & 0 & 5.015 \\
\hline
\end{tabular}

Panel B: Firm Characteristics

\begin{tabular}{lcccccc}
\hline Variables & Obs. & Mean & Median & Maximum & Minimum & Std. \\
\hline Firm Policies & & & & & & \\
Leverage & 5,139 & 0.177 & 0.138 & 0.768 & 0.000 & 0.168 \\
Net Capital Expenditure & 5,139 & 0.029 & 0.002 & 0.250 & 0.000 & 0.049 \\
R\&D Expenditures/Total Assets & 5,139 & 0.013 & 0.000 & 0.170 & 0.000 & 0.027 \\
Advertising/Total Assets & 5,126 & 0.054 & 0.039 & 0.287 & 0.004 & 0.048 \\
Total risk (Daily Stock Return Std.) & 5,113 & 0.384 & 0.346 & 1.098 & 0.153 & 0.171 \\
Firm-specific Risk (CAPM) & 5,113 & 0.343 & 0.305 & 1.007 & 0.133 & 0.159 \\
Firm-specific Risk (Four Factor) & 5,113 & 0.330 & 0.293 & 1.367 & 0.085 & 0.156 \\
Market Risk (CAPM) & 5,113 & 1.087 & 1.019 & 2.674 & 0.033 & 0.522 \\
\hline
\end{tabular}


Table 5 Continued.

Panel B: Firm Characteristics (Continued)

\begin{tabular}{lcccccc}
\hline Variables & Obs. & Mean & Median & Maximum & Minimum & Std. \\
\hline \multicolumn{1}{l}{ Other Firm and CEO Control Variables } & & & & & & \\
ln(Sales) & 5,139 & 7.481 & 7.366 & 12.716 & 1.800 & 1.521 \\
Firm Age & 5,139 & 58.709 & 50 & 164 & 3 & 38.354 \\
Capital Intensity & 5,139 & 0.283 & 0.220 & 0.884 & 0.016 & 0.216 \\
Herfindhal Index & 5,139 & 0.060 & 0.047 & 0.830 & 0.011 & 0.064 \\
Industry Homogeneity & 4,912 & 0.206 & 0.175 & 0.488 & 0.075 & 0.098 \\
Activist Institutional Holding & 5,139 & 0.030 & 0.028 & 0.092 & 0.000 & 0.013 \\
Depreciation/Total Assets & 5,139 & 0.043 & 0.039 & 0.144 & 0.006 & 0.024 \\
Surplus Cash & 5,074 & 0.093 & 0.079 & 0.927 & -0.639 & 0.091 \\
Pay director equity based & & & & & & \\
compensation (\%) & 5,139 & $69.20 \%$ & 1.000 & 1.000 & 0.000 & 0.462 \\
CEO Compensation Delta (M\$) & 5,139 & 0.535 & 0.205 & 6.394 & 0.000 & 0.987 \\
CEO Compensation Vega (M\$) & 5,139 & 0.281 & 0.109 & 2.497 & 0.000 & 0.465 \\
CEO Cash Compensation & 5,139 & 0.547 & 0.534 & 1.000 & 0.021 & 0.325 \\
& & & & & & \\
Firm Performance & & & & & & \\
Return on Equity (ROE) & 5,139 & 0.129 & 0.130 & 1.418 & -1.198 & 0.229 \\
Industry Median Adjusted ROE & 5,139 & 0.064 & 0.050 & 1.305 & -1.244 & 0.229 \\
Operating Return on Assets (ROA) & 5,139 & 0.100 & 0.100 & 0.316 & -0.332 & 0.076 \\
Industry Median Adjusted OROA & 5,139 & 0.060 & 0.041 & 0.457 & -0.332 & 0.104 \\
Annual Stock Return (RET) & 5,139 & 0.104 & 0.056 & 2.046 & -0.729 & 0.420 \\
Industry Median Adjusted RET & 5,139 & 0.083 & 0.030 & 1.974 & -0.708 & 0.397 \\
Sales Growth & 5,139 & 0.124 & 0.092 & 1.285 & -0.441 & 0.215 \\
Industry Median Adjusted Sales & & & & & & \\
Growth & 5,139 & 0.025 & 0.000 & 1.148 & -0.503 & 0.200 \\
Tobin's Q & 5,139 & 2.018 & 1.630 & 8.727 & 0.785 & 1.240 \\
Industry Median Adjusted Q & 5,139 & 0.374 & 0.065 & 6.671 & -1.470 & 1.148 \\
\hline
\end{tabular}

Panel C. Correlations for CEO Employment History Variables (5,139 Obs)

\begin{tabular}{lcccc}
\hline & \# Employers & $\begin{array}{l}\text { \# Employer } \\
\text { Changes per year }\end{array}$ & $\begin{array}{l}\text { Employer } \\
\text { Change Recency }\end{array}$ & $\begin{array}{l}\text { Firm Exp. } \\
\text { Diversification }\end{array}$ \\
\hline \# Employers & 1 & & & \\
\# Employer Changes per year & 0.834 & 1 & & \\
Employer Change Recency & 0.893 & 0.776 & 1 & \\
Firm Exp. Diversification & -0.820 & -0.713 & -0.757 & 1 \\
Industry Exp. Diversification & -0.623 & -0.533 & -0.568 & 0.718 \\
\hline
\end{tabular}




\section{Table 6. Differences in Post-turnover Firm Policies for CEOs with different employment histories}

This table presents differences in post-turnover firm policies for CEOs that have worked for different numbers of employers. Refer to Table 1 and Appendix A for variable definitions. Q1 includes CEOs in the bottom quartile and Q4 includes CEOs in the top quartile. Q4-Q1 is the difference in means (medians) between the top and the bottom quartiles. Panel A presents differences in post-turnover firm policies. Panel B presents differences in industry-median-adjusted changes in firm policies when firm policies prior to the CEO turnover are lower than the corresponding industry medians. Panel $\mathrm{C}$ presents differences in industry-medianadjusted changes in firm policies when firm policies prior to the CEO turnover are higher than the corresponding industry medians. ***, **, and * indicate significance at the 1, 5, and $10 \%$ levels, respectively.

Panel A: Differences in Post-Turnover Firm Policies

\begin{tabular}{|c|c|c|c|c|c|c|c|c|c|c|c|}
\hline & \multicolumn{3}{|c|}{ \# Employers $=1$} & \multicolumn{2}{|c|}{ \# Employers $=2$} & \multicolumn{2}{|c|}{ \# Employers $=3,4$} & \multicolumn{2}{|c|}{ \# Employers $>=5$} & \multicolumn{2}{|c|}{ Q4-Q1 } \\
\hline & Obs. & Mean & Median & Mean & Median & Mean & Median & Mean & Median & Mean & Median \\
\hline Market Leverage & 5,139 & 0.187 & 0.148 & 0.172 & 0.128 & 0.168 & 0.135 & 0.186 & 0.139 & -0.001 & $-0.009 *$ \\
\hline R\&D Exp./Total Assets & 5,139 & 0.015 & 0.000 & 0.031 & 0.006 & 0.036 & 0.008 & 0.030 & 0.000 & $0.015^{* * *}$ & $0.000 * * *$ \\
\hline Advertising/Total Assets & 5,139 & 0.015 & 0.000 & 0.011 & 0.000 & 0.011 & 0.000 & 0.015 & 0.000 & 0.000 & 0.000 \\
\hline Capital Expenditure & 5,126 & 0.060 & 0.045 & 0.054 & 0.041 & 0.052 & 0.036 & 0.053 & 0.035 & $-0.008 * * *$ & $-0.010 * * *$ \\
\hline Total Risk (Daily Stock Std.) & 5,113 & 0.342 & 0.312 & 0.373 & 0.338 & 0.402 & 0.361 & 0.417 & 0.368 & $0.075 * * *$ & $0.056^{* * *}$ \\
\hline Market Risk & 5,113 & 0.987 & 0.946 & 1.070 & 0.987 & 1.145 & 1.078 & 1.129 & 1.070 & $0.142 * * *$ & $0.124 * * *$ \\
\hline Firm-specific Risk (CAPM) & 5,113 & 0.303 & 0.271 & 0.331 & 0.295 & 0.358 & 0.320 & 0.376 & 0.330 & $0.073 * * *$ & $0.059 * * *$ \\
\hline \multirow[t]{4}{*}{ Firm-specific Risk (4 Factors) } & 5,113 & 0.292 & 0.261 & 0.319 & 0.283 & 0.345 & 0.308 & 0.364 & 0.319 & $0.072 * * *$ & $0.058 * * *$ \\
\hline & \multicolumn{11}{|c|}{ Panel B: Differences in Industry-Median-Adjusted Changes in Firm Policies (Prior Policy <=Industry Median) } \\
\hline & & \multicolumn{2}{|c|}{ \# Employers=1 } & \multicolumn{2}{|c|}{ \# Employers $=2$} & \multicolumn{2}{|c|}{ \# Employers $=3,4$} & \multicolumn{2}{|c|}{ \# Employers $>=5$} & \multicolumn{2}{|c|}{$\underline{Q 4-Q 1}$} \\
\hline & Obs. & Mean & Median & Mean & Median & Mean & Median & Mean & Median & Mean & Median \\
\hline Market Leverage & 2,729 & 0.078 & 0.054 & 0.066 & 0.051 & 0.063 & 0.041 & 0.094 & 0.063 & $0.016^{* *}$ & $0.009 * * *$ \\
\hline R\&D Exp./Total Assets & 3,229 & 0.000 & 0.000 & 0.002 & 0.000 & 0.005 & 0.000 & 0.001 & 0.000 & 0.001 & 0.000 \\
\hline Advertising/Total Assets & 3,593 & 0.002 & 0.000 & 0.002 & 0.000 & 0.004 & 0.000 & 0.004 & 0.000 & $0.003 * * *$ & $0.000 * * *$ \\
\hline Capital Expenditure & 2,052 & 0.011 & 0.011 & 0.013 & 0.011 & 0.018 & 0.011 & 0.015 & 0.007 & $0.004 *$ & $-0.004 * *$ \\
\hline Total Risk (Daily Stock Std.) & 3,779 & 0.004 & 0.003 & 0.003 & 0.003 & 0.003 & 0.003 & 0.004 & 0.003 & 0.001 & $0.000 *$ \\
\hline Market Risk (CAPM) & 1,753 & -0.017 & -0.028 & 0.007 & -0.006 & 0.034 & 0.014 & 0.005 & -0.010 & 0.022 & 0.017 \\
\hline Firm-specific Risk (CAPM) & 3,885 & 0.003 & 0.002 & 0.003 & 0.003 & 0.003 & 0.002 & 0.004 & 0.003 & $0.001 * *$ & $0.001 * *$ \\
\hline Firm-specific Risk (4 Factors) & 3,908 & 0.003 & 0.003 & 0.003 & 0.002 & 0.002 & 0.002 & 0.004 & 0.003 & $0.001^{*}$ & $0.001 * *$ \\
\hline
\end{tabular}


Table 6 Continued.

Panel C. Differences in Industry-Median-Adjusted Changes in Firm Policies (Prior Policy > Industry Median)

\begin{tabular}{|c|c|c|c|c|c|c|c|c|c|c|c|}
\hline & \multirow[b]{2}{*}{ Obs. } & \multicolumn{2}{|c|}{ \# Employers=1 } & \multicolumn{2}{|c|}{ \# Employers $=2$} & \multicolumn{2}{|c|}{ \# Employers = 3, 4} & \multicolumn{2}{|c|}{ \# Employers $>=5$} & \multicolumn{2}{|c|}{ Q4-Q1 } \\
\hline & & Mean & Median & Mean & Median & Mean & Median & Mean & Median & Mean & Median \\
\hline Market Leverage & 2,097 & -0.055 & -0.054 & -0.057 & -0.032 & -0.077 & -0.067 & -0.135 & -0.092 & -0.080 & -0.039 \\
\hline R\&D Exp./Total Assets & 1,910 & -0.006 & -0.003 & -0.010 & -0.003 & -0.022 & -0.005 & -0.029 & -0.010 & $-0.023 * * *$ & $-0.007 * * *$ \\
\hline Advertising/Total Assets & 1,546 & -0.007 & 0.000 & -0.002 & 0.000 & 0.002 & 0.000 & -0.001 & 0.000 & $0.006 * * *$ & $0.000 * *$ \\
\hline Capital Expenditure & 3,024 & -0.014 & -0.013 & -0.023 & -0.015 & -0.024 & -0.016 & -0.018 & -0.014 & $-0.005 *$ & $-0.002 *$ \\
\hline Total Risk (Daily Stock Std.) & 914 & -0.010 & -0.007 & -0.013 & -0.010 & -0.016 & -0.011 & -0.010 & -0.008 & 0.000 & -0.001 \\
\hline Market Risk (CAPM) & 1,940 & -0.089 & -0.202 & 0.013 & -0.031 & 0.013 & -0.031 & -0.161 & -0.158 & -0.072 & 0.044 \\
\hline Firm-specific Risk (CAPM) & 808 & -0.009 & -0.006 & -0.012 & -0.012 & -0.016 & -0.011 & -0.009 & -0.007 & -0.001 & -0.001 \\
\hline Firm-specific Risk (4 Factors) & 785 & -0.009 & -0.007 & -0.012 & -0.012 & -0.015 & -0.011 & -0.009 & -0.007 & -0.001 & -0.001 \\
\hline
\end{tabular}




\section{Table 7. CEO-Firm Matching - First-stage Regression Results}

This table presents first-stage OLS results for the debt policy regression on the sample of 4,826 post-turnover firm years from 1992 to 2007. The dependent variables are listed at the top of each column. Refer to Table 1 and Appendix A for variable definitions. Instrumental variables are the unemployment rate for the year when the CEO started his first full-time job, non-business career dummy that equals one if the CEO had academic or government jobs, and \# Years working in the current firm's industry is the number of year the CEO has worked in his current firm's industry. I report $p$-values based on robust standard errors clustered at the firm level in parenthesis. ***, **, and $*$ indicate significance at the 1,5 , and $10 \%$ levels, respectively.

\begin{tabular}{|c|c|c|c|c|c|}
\hline & \# Employers & $\begin{array}{c}\text { \# Employer } \\
\text { Changes per } \\
\text { year }\end{array}$ & $\begin{array}{c}\text { Firm } \\
\text { Experience } \\
\text { Recency }\end{array}$ & $\begin{array}{c}\text { Firm } \\
\text { Experience } \\
\text { Diversification }\end{array}$ & $\begin{array}{c}\text { Industry } \\
\text { Experience } \\
\text { Diversification }\end{array}$ \\
\hline \multicolumn{6}{|l|}{ Instrumental Variables: } \\
\hline Unemployment Rate & $\begin{array}{l}-0.026 \\
(0.107)\end{array}$ & $\begin{array}{c}0.001 * * * \\
(0.009)\end{array}$ & $\begin{array}{l}-0.010 \\
(0.299)\end{array}$ & $\begin{array}{c}0.001 \\
(0.540)\end{array}$ & $\begin{array}{l}-0.001 \\
(0.594)\end{array}$ \\
\hline Has Non-business Career (0/1) & $\begin{array}{l}0.125^{*} \\
(0.079)\end{array}$ & $\begin{array}{c}0.001 \\
(0.539)\end{array}$ & $\begin{array}{c}0.258^{* * * *} \\
(0.000)\end{array}$ & $\begin{array}{c}-0.086 * * * \\
(0.000)\end{array}$ & $\begin{array}{c}-0.094 * * * \\
(0.000)\end{array}$ \\
\hline $\begin{array}{l}\text { \#Years working in the current } \\
\text { firm's industry }\end{array}$ & $\begin{array}{c}-0.069 * * * \\
(0.000)\end{array}$ & $\begin{array}{c}-0.002 * * * \\
(0.000)\end{array}$ & $\begin{array}{c}-0.044 * * * \\
(0.000)\end{array}$ & $\begin{array}{l}0.012 * * * \\
(0.000)\end{array}$ & $\begin{array}{c}0.018 * * * \\
(0.000)\end{array}$ \\
\hline \multicolumn{6}{|l|}{ Firm Characteristics } \\
\hline Pre-turnover Leverage & $\begin{array}{c}0.793 * * * \\
(0.000)\end{array}$ & $\begin{array}{c}0.029 * * * \\
(0.000)\end{array}$ & $\begin{array}{l}0.566^{* * *} \\
(0.000)\end{array}$ & $\begin{array}{c}-0.121 * * * \\
(0.000)\end{array}$ & $\begin{array}{c}-0.050^{* * *} \\
(0.000)\end{array}$ \\
\hline $\ln$ (Total Sales) & $\begin{array}{l}-0.185^{* * *} \\
(0.000)\end{array}$ & $\begin{array}{c}-0.007 * * * \\
(0.000)\end{array}$ & $\begin{array}{c}-0.087 * * * \\
(0.000)\end{array}$ & $\begin{array}{c}0.029 * * * \\
(0.000)\end{array}$ & $\begin{array}{c}0.007 * * * \\
(0.001)\end{array}$ \\
\hline Firm Age & $\begin{array}{l}-0.244 * * * \\
(0.000)\end{array}$ & $\begin{array}{c}-0.010^{* * *} \\
(0.000)\end{array}$ & $\begin{array}{c}-0.162 * * * \\
(0.000)\end{array}$ & $\begin{array}{l}0.066 * * * \\
(0.000)\end{array}$ & $\begin{array}{l}0.010^{* *} \\
(0.010)\end{array}$ \\
\hline Operating Return on Assets & $\begin{array}{l}-0.640^{*} \\
(0.058)\end{array}$ & $\begin{array}{c}-0.026^{* *} \\
(0.020)\end{array}$ & $\begin{array}{c}-0.408^{* *} \\
(0.044)\end{array}$ & $\begin{array}{l}0.111^{* *} \\
(0.022)\end{array}$ & $\begin{array}{l}-0.045 \\
(0.230)\end{array}$ \\
\hline Tobin's Q & $\begin{array}{l}-0.038 \\
(0.102)\end{array}$ & $\begin{array}{l}-0.001 \\
(0.188)\end{array}$ & $\begin{array}{c}-0.028^{* *} \\
(0.047)\end{array}$ & $\begin{array}{l}-0.003 \\
(0.448)\end{array}$ & $\begin{array}{c}0.007^{* * *} \\
(0.009)\end{array}$ \\
\hline R\&D Exp./Total Assets & $\begin{array}{c}-1.820^{* *} \\
(0.023)\end{array}$ & $\begin{array}{c}-0.038^{* *} \\
(0.039)\end{array}$ & $\begin{array}{l}-0.146 \\
(0.656)\end{array}$ & $\begin{array}{l}0.143^{*} \\
(0.069)\end{array}$ & $\begin{array}{l}-0.014 \\
(0.824)\end{array}$ \\
\hline Capital Intensity & $\begin{array}{c}-0.606 * * * \\
(0.000)\end{array}$ & $\begin{array}{c}-0.019 * * * \\
(0.000)\end{array}$ & $\begin{array}{c}-0.204 * * * \\
(0.009)\end{array}$ & $\begin{array}{l}-0.002 \\
(0.917)\end{array}$ & $\begin{array}{c}0.042 * * * \\
(0.004)\end{array}$ \\
\hline Depreciation/Total Assets & $\begin{array}{c}6.901 * * * \\
(0.000)\end{array}$ & $\begin{array}{c}0.211^{* * *} \\
(0.000)\end{array}$ & $\begin{array}{c}3.730 * * * \\
(0.000)\end{array}$ & $\begin{array}{l}-0.314^{*} \\
(0.051)\end{array}$ & $\begin{array}{c}0.108 \\
(0.390)\end{array}$ \\
\hline $\begin{array}{l}\text { Pay directors equity based } \\
\text { compensation }(0 / 1)\end{array}$ & $\begin{array}{c}0.066 \\
(0.253)\end{array}$ & $\begin{array}{c}0.002 \\
(0.337)\end{array}$ & $\begin{array}{c}0.040 \\
(0.248)\end{array}$ & $\begin{array}{l}-0.013 \\
(0.112)\end{array}$ & $\begin{array}{l}-0.006 \\
(0.390)\end{array}$ \\
\hline Activist Institutional Hldg. (\%) & $\begin{array}{l}-2.275 \\
(0.177)\end{array}$ & $\begin{array}{l}-0.090 \\
(0.110)\end{array}$ & $\begin{array}{l}-1.498 \\
(0.137)\end{array}$ & $\begin{array}{c}0.302 \\
(0.211)\end{array}$ & $\begin{array}{l}0.314^{*} \\
(0.096)\end{array}$ \\
\hline CEO Cash Compensation & $\begin{array}{c}0.073 \\
(0.316)\end{array}$ & $\begin{array}{c}0.000 \\
(0.892)\end{array}$ & $\begin{array}{c}0.053 \\
(0.228)\end{array}$ & $\begin{array}{l}0.021 * * \\
(0.044)\end{array}$ & $\begin{array}{l}-0.005 \\
(0.561)\end{array}$ \\
\hline Compensation Delta & $\begin{array}{l}-0.004 \\
(0.912)\end{array}$ & $\begin{array}{l}-0.001 \\
(0.235)\end{array}$ & $\begin{array}{c}0.022 \\
(0.241)\end{array}$ & $\begin{array}{c}0.004 \\
(0.378)\end{array}$ & $\begin{array}{c}0.003 \\
(0.355)\end{array}$ \\
\hline Compensation Vega & $\begin{array}{c}0.235^{* * *} \\
(0.001)\end{array}$ & $\begin{array}{c}0.012 * * * \\
(0.000)\end{array}$ & $\begin{array}{l}0.097 * * \\
(0.026)\end{array}$ & $\begin{array}{c}-0.051 * * * \\
(0.000)\end{array}$ & $\begin{array}{c}-0.016^{* *} \\
(0.048)\end{array}$ \\
\hline Herfindhal Index & $\begin{array}{c}-2.272 * * * \\
(0.000)\end{array}$ & $\begin{array}{c}-0.069^{* * *} \\
(0.000)\end{array}$ & $\begin{array}{c}-0.835^{* * *} \\
(0.000)\end{array}$ & $\begin{array}{c}0.382 * * * \\
(0.000)\end{array}$ & $\begin{array}{l}0.060^{*} \\
(0.091)\end{array}$ \\
\hline
\end{tabular}


Table 7 Continued.

\begin{tabular}{|c|c|c|c|c|c|}
\hline \multicolumn{6}{|l|}{ CEO Characteristics } \\
\hline Ln(CEO Tenure +1$)$ & $\begin{array}{c}-0.124 * * * \\
(0.001)\end{array}$ & $\begin{array}{c}-0.005 * * * \\
(0.000)\end{array}$ & $\begin{array}{c}-0.231 * * * \\
(0.000)\end{array}$ & $\begin{array}{c}0.012 * * \\
(0.026)\end{array}$ & $\begin{array}{c}-0.026 * * * \\
(0.000)\end{array}$ \\
\hline Ln (CEO Age) & $\begin{array}{c}3.560 * * * \\
(0.000)\end{array}$ & $\begin{array}{c}-0.017 * * \\
(0.023)\end{array}$ & $\begin{array}{c}2.232 * * * \\
(0.000)\end{array}$ & $\begin{array}{c}-0.504 * * * \\
(0.000)\end{array}$ & $\begin{array}{c}-0.580 * * * \\
(0.000)\end{array}$ \\
\hline $\operatorname{MBA}(0 / 1)$ & $\begin{array}{c}0.141 * * * \\
(0.001)\end{array}$ & $\begin{array}{c}0.008 * * * \\
(0.000)\end{array}$ & $\begin{array}{c}0.035 \\
(0.175)\end{array}$ & $\begin{array}{c}-0.028 * * * \\
(0.000)\end{array}$ & $\begin{array}{c}-0.029 * * * \\
(0.000)\end{array}$ \\
\hline Founder $(0 / 1)$ & $\begin{array}{c}-0.769 * * * \\
(0.000)\end{array}$ & $\begin{array}{c}-0.027 * * * \\
(0.000)\end{array}$ & $\begin{array}{c}-0.414 * * * \\
(0.000)\end{array}$ & $\begin{array}{c}0.174 * * * \\
(0.000)\end{array}$ & $\begin{array}{c}0.077 * * * \\
(0.000)\end{array}$ \\
\hline \# Functional Areas & $\begin{array}{c}0.139 * * * \\
(0.000)\end{array}$ & $\begin{array}{c}0.004 * * * \\
(0.000)\end{array}$ & $\begin{array}{c}0.040 * * * \\
(0.003)\end{array}$ & $\begin{array}{c}-0.009 * * * \\
(0.008)\end{array}$ & $\begin{array}{c}-0.014 * * * \\
(0.000)\end{array}$ \\
\hline Has Finance Background (0/1) & $\begin{array}{c}0.105 * * \\
(0.034)\end{array}$ & $\begin{array}{c}0.005^{* * *} \\
(0.004)\end{array}$ & $\begin{array}{c}0.040 \\
(0.180)\end{array}$ & $\begin{array}{c}-0.016 * * \\
(0.023)\end{array}$ & $\begin{array}{c}-0.040 * * * \\
(0.000)\end{array}$ \\
\hline Constant & $\begin{array}{c}-7.613 * * * \\
(0.000)\end{array}$ & $\begin{array}{c}0.285^{* * *} * \\
(0.000)\end{array}$ & $\begin{array}{c}-5.613 * * * \\
(0.000)\end{array}$ & $\begin{array}{c}1.875^{* * *} * \\
(0.000)\end{array}$ & $\begin{array}{c}2.589 * * * \\
(0.000)\end{array}$ \\
\hline Year Dummies & Yes & Yes & Yes & Yes & Yes \\
\hline Industry Dummies & Yes & Yes & Yes & Yes & Yes \\
\hline Observations & 4826 & 4826 & 4826 & 4826 & 4826 \\
\hline R-squared & 0.364 & 0.384 & 0.386 & 0.472 & 0.634 \\
\hline
\end{tabular}


Table 8. CEO Employment History and Financing Policy

This table presents IV/2SLS results for the financing policy on the sample of 4,826 firm years. The dependent variable is Leverage. Refer to Table 1 and Appendix A for variable definitions. Pre-turnover Leverage is the firm's Leverage in the year before the year of CEO turnover. Instrumental variables are the unemployment rate for the year when the CEO started his first full-time job, non-business career dummy that equals one if the CEO had academic or government jobs, and the number of years the CEO has worked in his current firm's industry. I report $p$-values of Hansen's J-test and first-stage $F$-stat at the bottom of the table. The values of the five CEO employment history proxies in the IV/2SLS estimations are predicted values. The predicted signs for the CEO employment history proxies are presented in parenthesis at the beginning of each row. I report $p$-values based on robust standard errors clustered at the firm level in parenthesis. ${ }^{* * *}, * *$, and $*$ indicate significance at the 1,5 , and $10 \%$ levels, respectively.

\begin{tabular}{|c|c|c|c|c|c|c|}
\hline \multirow[b]{2}{*}{ CEO Employment History Variables } & & (1) & (2) & (3) & (4) & (5) \\
\hline & & & & & & \\
\hline \# Employers & $(+)$ & $\begin{array}{l}0.012 * * \\
(0.025)\end{array}$ & & & & \\
\hline \# Employer Changes per year & $(+)$ & & $\begin{array}{l}0.376^{* *} \\
(0.033)\end{array}$ & & & \\
\hline Employer Change Recency & $(+)$ & & & $\begin{array}{c}0.020 * * \\
(0.021)\end{array}$ & & \\
\hline Firm Experience Diversification & $(-)$ & & & & $\begin{array}{c}-0.071 * * \\
(0.020)\end{array}$ & \\
\hline Industry Experience Diversification & $(-)$ & & & & & $\begin{array}{c}-0.051 * * \\
(0.019)\end{array}$ \\
\hline \multicolumn{7}{|l|}{ Firm Characteristics } \\
\hline$\overline{\text { Pre-turnover Leverage }}$ & & $\begin{array}{c}0.258^{* * *} \\
(0.000)\end{array}$ & $\begin{array}{c}0.257^{* * *} \\
(0.000)\end{array}$ & $\begin{array}{c}0.253^{* * *} \\
(0.000)\end{array}$ & $\begin{array}{c}0.261^{* * *} \\
(0.000)\end{array}$ & $\begin{array}{c}0.264^{* * *} \\
(0.000)\end{array}$ \\
\hline $\ln$ (Total Sales) & & $\begin{array}{c}0.021^{* * *} \\
(0.000)\end{array}$ & $\begin{array}{c}0.021^{* * *} \\
(0.000)\end{array}$ & $\begin{array}{c}0.021^{* * *} \\
(0.000)\end{array}$ & $\begin{array}{c}0.021^{* * *} \\
(0.000)\end{array}$ & $\begin{array}{c}0.019 * * * \\
(0.000)\end{array}$ \\
\hline Firm Age & & $\begin{array}{l}-0.005 \\
(0.444)\end{array}$ & $\begin{array}{l}-0.005 \\
(0.505)\end{array}$ & $\begin{array}{l}-0.005 \\
(0.434)\end{array}$ & $\begin{array}{l}-0.003 \\
(0.658)\end{array}$ & $\begin{array}{l}-0.006 \\
(0.329)\end{array}$ \\
\hline Operating Return on Assets & & $\begin{array}{c}-0.576^{* * *} \\
(0.000)\end{array}$ & $\begin{array}{c}-0.573 * * * \\
(0.000)\end{array}$ & $\begin{array}{c}-0.574 * * * \\
(0.000)\end{array}$ & $\begin{array}{c}-0.575^{* * *} \\
(0.000)\end{array}$ & $\begin{array}{c}-0.583 * * * \\
(0.000)\end{array}$ \\
\hline Tobin's Q & & $\begin{array}{c}-0.021 * * * \\
(0.000)\end{array}$ & $\begin{array}{c}-0.021 * * * \\
(0.000)\end{array}$ & $\begin{array}{c}-0.021 * * * \\
(0.000)\end{array}$ & $\begin{array}{c}-0.022 * * * \\
(0.000)\end{array}$ & $\begin{array}{c}-0.022 * * * \\
(0.000)\end{array}$ \\
\hline R\&D Exp./Total Assets & & $\begin{array}{c}-0.345^{* * *} \\
(0.000)\end{array}$ & $\begin{array}{c}-0.354 * * * \\
(0.000)\end{array}$ & $\begin{array}{c}-0.355^{* * *} \\
(0.000)\end{array}$ & $\begin{array}{l}-0.344 * * * \\
(0.000)\end{array}$ & $\begin{array}{c}-0.338^{* * *} \\
(0.000)\end{array}$ \\
\hline Capital Intensity & & $\begin{array}{c}0.123 * * * \\
(0.000)\end{array}$ & $\begin{array}{c}0.119^{* * *} \\
(0.000)\end{array}$ & $\begin{array}{c}0.118^{* * *} \\
(0.000)\end{array}$ & $\begin{array}{c}0.114 * * * \\
(0.000)\end{array}$ & $\begin{array}{c}0.111 * * * \\
(0.000)\end{array}$ \\
\hline Depreciation/Total Assets & & $\begin{array}{l}-0.117 \\
(0.524)\end{array}$ & $\begin{array}{l}-0.101 \\
(0.584)\end{array}$ & $\begin{array}{l}-0.110 \\
(0.544)\end{array}$ & $\begin{array}{l}-0.055 \\
(0.760)\end{array}$ & $\begin{array}{l}-0.037 \\
(0.836)\end{array}$ \\
\hline $\begin{array}{l}\text { Pay Directors Equity Based } \\
\text { Compensation }(0 / 1)\end{array}$ & & $\begin{array}{c}0.011 \\
(0.117)\end{array}$ & $\begin{array}{c}0.011 \\
(0.104)\end{array}$ & $\begin{array}{c}0.011 \\
(0.124)\end{array}$ & $\begin{array}{c}0.011 \\
(0.113)\end{array}$ & $\begin{array}{l}0.011^{*} \\
(0.092)\end{array}$ \\
\hline Activist Institutional Holding (\%) & & $\begin{array}{l}-0.274 \\
(0.294)\end{array}$ & $\begin{array}{l}-0.266 \\
(0.304)\end{array}$ & $\begin{array}{l}-0.268 \\
(0.303)\end{array}$ & $\begin{array}{l}-0.271 \\
(0.297)\end{array}$ & $\begin{array}{l}-0.270 \\
(0.291)\end{array}$ \\
\hline CEO Cash Compensation & & $\begin{array}{l}0.016^{* *} \\
(0.033)\end{array}$ & $\begin{array}{l}0.017 * * \\
(0.024)\end{array}$ & $\begin{array}{l}0.016^{* *} \\
(0.037)\end{array}$ & $\begin{array}{l}0.018^{* *} \\
(0.017)\end{array}$ & $\begin{array}{c}0.016^{* *} \\
(0.028)\end{array}$ \\
\hline CEO Compensation Delta & & $\begin{array}{l}-0.006 \\
(0.133)\end{array}$ & $\begin{array}{l}-0.006 \\
(0.157)\end{array}$ & $\begin{array}{l}-0.007 \\
(0.105)\end{array}$ & $\begin{array}{l}-0.006 \\
(0.165)\end{array}$ & $\begin{array}{l}-0.006 \\
(0.141)\end{array}$ \\
\hline CEO Compensation Vega & & $\begin{array}{c}-0.020^{* *} \\
(0.041)\end{array}$ & $\begin{array}{c}-0.021 * * \\
(0.033)\end{array}$ & $\begin{array}{c}-0.019 * * \\
(0.049)\end{array}$ & $\begin{array}{c}-0.021^{* *} \\
(0.032)\end{array}$ & $\begin{array}{l}-0.018^{*} \\
(0.055)\end{array}$ \\
\hline Herfindhal Index & & $\begin{array}{c}0.339 * * * \\
(0.005)\end{array}$ & $\begin{array}{c}0.332 * * * \\
(0.006)\end{array}$ & $\begin{array}{c}0.319 * * * \\
(0.008)\end{array}$ & $\begin{array}{c}0.350 * * * \\
(0.004)\end{array}$ & $\begin{array}{c}0.335 * * * \\
(0.006)\end{array}$ \\
\hline
\end{tabular}


Table 8 Continued.

\begin{tabular}{lccccc}
\hline CEO Characteristics & & & & & \\
Ln(CEO Tenure+1) & 0.005 & 0.006 & 0.009 & 0.004 & 0.002 \\
CEO Age & $(0.362)$ & $(0.344)$ & $(0.178)$ & $(0.445)$ & $(0.667)$ \\
& $-0.080^{* *}$ & -0.022 & $-0.081^{* *}$ & $-0.071^{* *}$ & $-0.060^{* *}$ \\
MBA (0/1) & $(0.016)$ & $(0.512)$ & $(0.015)$ & $(0.024)$ & $(0.046)$ \\
& $0.014^{*}$ & $0.013^{*}$ & $0.015^{* *}$ & $0.014^{*}$ & $0.015^{* *}$ \\
Founder (0/1) & $(0.068)$ & $(0.094)$ & $(0.043)$ & $(0.070)$ & $(0.050)$ \\
& 0.016 & 0.016 & 0.015 & 0.018 & 0.009 \\
\# Functional Areas & $(0.284)$ & $(0.290)$ & $(0.301)$ & $(0.231)$ & $(0.502)$ \\
& -0.002 & -0.002 & -0.001 & -0.001 & -0.001 \\
Has Finance Background (0/1) & $(0.625)$ & $(0.658)$ & $(0.792)$ & $(0.792)$ & $(0.820)$ \\
& 0.011 & 0.010 & 0.011 & 0.011 & 0.010 \\
Constant & $(0.237)$ & $(0.259)$ & $(0.229)$ & $(0.211)$ & $(0.286)$ \\
& $0.285^{* *}$ & 0.057 & $0.305^{* *}$ & $0.318^{* *}$ & $0.297^{* *}$ \\
Year Dummies & $(0.050)$ & $(0.723)$ & $(0.036)$ & $(0.034)$ & $(0.039)$ \\
Industry Dummies & Yes & Yes & Yes & Yes & Yes \\
Observations & Yes & Yes & Yes & Yes & Yes \\
Adjusted R-squared & 4826 & 4826 & 4826 & 4826 & 4826 \\
& 0.572 & 0.570 & 0.570 & 0.572 & 0.578 \\
Hansen's J-test (p-value) & & & & & \\
First-stage Instrumental Variables' Joint & 0.535 & 0.406 & 0.684 & 0.673 & 0.643 \\
Significance (F-stat) & & & & & \\
\end{tabular}


Table 9. CEO Employment History and Capital Expenditures

This table presents IV/2SLS results for investments in capital expenditures on a sample of 5,029 firm years. The dependent variable is capital expenditures divided by total assets. Refer to Table 1 and Appendix A for variable definitions. Pre-turnover Capital Exp. is the firm's capital expenditure/total assets in the year before the CEO turnover year. Instrumental variables are the unemployment rate for the year when the CEO started his first full-time job, non-business career dummy that equals one if the CEO had academic or government jobs, and the number of years the CEO has worked in his current firm's industry. I report $p$-values of Hansen's J-test and first-stage $F$-stat at the bottom of the table. The values of the five CEO employment history proxies in the IV/2SLS estimations are predicted values. The predicted signs for the CEO employment history proxies are presented in parenthesis at the beginning of each row. I report $p$-values based on robust standard errors clustered at the firm level in parenthesis. $* * *, * *$, and $*$ indicate significance at the 1,5 , and $10 \%$ levels, respectively.

\begin{tabular}{|c|c|c|c|c|c|c|}
\hline & & $(1)$ & (2) & (3) & (4) & $(5)$ \\
\hline \multicolumn{7}{|l|}{ CEO Employment History Variables } \\
\hline \# Employers & $(-)$ & $\begin{array}{c}-0.004 * * * \\
(0.005)\end{array}$ & & & & \\
\hline \# Employer Changes per year & $(-)$ & & $\begin{array}{l}-0.120 * * * \\
(0.005)\end{array}$ & & & \\
\hline Employer Change Recency & $(-)$ & & & $\begin{array}{c}-0.006 * * * \\
(0.007)\end{array}$ & & \\
\hline Firm Experience Diversification & $(+)$ & & & & $\begin{array}{c}0.020 * * * \\
(0.006)\end{array}$ & \\
\hline Industry Experience Diversification & $(+)$ & & & & & $\begin{array}{c}0.015 * * * \\
(0.005)\end{array}$ \\
\hline \multicolumn{7}{|l|}{ Firm Characteristics } \\
\hline 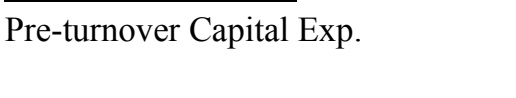 & & $\begin{array}{c}0.302 * * * \\
(0.000)\end{array}$ & $\begin{array}{c}0.301 * * * \\
(0.000)\end{array}$ & $\begin{array}{c}0.303 * * * \\
(0.000)\end{array}$ & $\begin{array}{c}0.304 * * * \\
(0.000)\end{array}$ & $\begin{array}{r}0.308^{* * *} \\
(0.000)\end{array}$ \\
\hline $\ln ($ Total Sales) & & $\begin{array}{c}-0.002 * * \\
(0.024)\end{array}$ & $\begin{array}{c}-0.002 * * \\
(0.023)\end{array}$ & $\begin{array}{c}-0.002 * * \\
(0.031)\end{array}$ & $\begin{array}{c}-0.002 * * \\
(0.027)\end{array}$ & $\begin{array}{l}-0.002 * \\
(0.087)\end{array}$ \\
\hline Firm Age & & $\begin{array}{c}0.001 \\
(0.771)\end{array}$ & $\begin{array}{c}0.000 \\
(0.886)\end{array}$ & $\begin{array}{c}0.001 \\
(0.749)\end{array}$ & $\begin{array}{c}0.000 \\
(0.988)\end{array}$ & $\begin{array}{c}0.001 \\
(0.532)\end{array}$ \\
\hline Surplus Cash & & $\begin{array}{l}0.020^{* *} \\
(0.018)\end{array}$ & $\begin{array}{l}0.020 * * \\
(0.025)\end{array}$ & $\begin{array}{l}0.020^{* *} \\
(0.020)\end{array}$ & $\begin{array}{l}0.022 * * \\
(0.011)\end{array}$ & $\begin{array}{c}0.023^{* * *} \\
(0.006)\end{array}$ \\
\hline Tobin's Q & & $\begin{array}{c}0.003 * * * \\
(0.002)\end{array}$ & $\begin{array}{c}0.003 * * * \\
(0.001)\end{array}$ & $\begin{array}{c}0.003 * * * \\
(0.002)\end{array}$ & $\begin{array}{c}0.003 * * * \\
(0.001)\end{array}$ & $\begin{array}{r}0.003 * * * \\
(0.001)\end{array}$ \\
\hline R\&D Exp./Total Assets & & $\begin{array}{l}-0.039^{*} \\
(0.083)\end{array}$ & $\begin{array}{l}-0.037 \\
(0.107)\end{array}$ & $\begin{array}{l}-0.036 \\
(0.107)\end{array}$ & $\begin{array}{l}-0.041^{*} \\
(0.070)\end{array}$ & $\begin{array}{l}-0.042 * \\
(0.055)\end{array}$ \\
\hline Advertising/Total Assets & & $\begin{array}{c}0.017 \\
(0.635)\end{array}$ & $\begin{array}{c}0.015 \\
(0.661)\end{array}$ & $\begin{array}{c}0.017 \\
(0.638)\end{array}$ & $\begin{array}{c}0.017 \\
(0.631)\end{array}$ & $\begin{array}{c}0.013 \\
(0.714)\end{array}$ \\
\hline Leverage & & $\begin{array}{l}-0.012 \\
(0.117)\end{array}$ & $\begin{array}{l}-0.012 \\
(0.128)\end{array}$ & $\begin{array}{l}-0.012 \\
(0.116)\end{array}$ & $\begin{array}{l}-0.012 \\
(0.101)\end{array}$ & $\begin{array}{l}-0.013^{*} \\
(0.080)\end{array}$ \\
\hline $\begin{array}{l}\text { Pay Directors Equity Based } \\
\text { Compensation }(0 / 1)\end{array}$ & & $\begin{array}{l}-0.001 \\
(0.779)\end{array}$ & $\begin{array}{l}-0.001 \\
(0.754)\end{array}$ & $\begin{array}{l}-0.001 \\
(0.743)\end{array}$ & $\begin{array}{l}-0.001 \\
(0.787)\end{array}$ & $\begin{array}{l}-0.001 \\
(0.710)\end{array}$ \\
\hline Activist Institutional Holding (\%) & & $\begin{array}{l}-0.060 \\
(0.342)\end{array}$ & $\begin{array}{l}-0.063 \\
(0.323)\end{array}$ & $\begin{array}{l}-0.058 \\
(0.360)\end{array}$ & $\begin{array}{l}-0.057 \\
(0.364)\end{array}$ & $\begin{array}{l}-0.058 \\
(0.342)\end{array}$ \\
\hline CEO Cash Compensation & & $\begin{array}{c}-0.003 \\
(0.153)\end{array}$ & $\begin{array}{c}-0.003 \\
(0.133)\end{array}$ & $\begin{array}{c}-0.003 \\
(0.162)\end{array}$ & $\begin{array}{l}-0.004^{*} \\
(0.088)\end{array}$ & $\begin{array}{c}-0.003 \\
(0.134)\end{array}$ \\
\hline CEO Compensation Delta & & $\begin{array}{c}-0.001 \\
(0.371)\end{array}$ & $\begin{array}{l}-0.001 \\
(0.333)\end{array}$ & $\begin{array}{l}-0.001 \\
(0.426)\end{array}$ & $\begin{array}{l}-0.001 \\
(0.247)\end{array}$ & $\begin{array}{l}-0.001 \\
(0.302)\end{array}$ \\
\hline CEO Compensation Vega & & $\begin{array}{c}-0.001 \\
(0.771)\end{array}$ & $\begin{array}{l}-0.000 \\
(0.901)\end{array}$ & $\begin{array}{l}-0.001 \\
(0.686)\end{array}$ & $\begin{array}{l}-0.000 \\
(0.941)\end{array}$ & $\begin{array}{c}-0.001 \\
(0.685)\end{array}$ \\
\hline Herfindhal Index & & $\begin{array}{l}-0.038 \\
(0.319)\end{array}$ & $\begin{array}{l}-0.036 \\
(0.342)\end{array}$ & $\begin{array}{c}-0.032 \\
(0.383)\end{array}$ & $\begin{array}{c}-0.042 \\
(0.257)\end{array}$ & $\begin{array}{l}-0.037 \\
(0.319)\end{array}$ \\
\hline
\end{tabular}


Table 9 Continued.

\begin{tabular}{lccccc}
\hline CEO Characteristics & & & & & \\
Ln(CEO Tenure+1) & $-0.004^{* *}$ & $-0.004^{* *}$ & $-0.005^{* * *}$ & $-0.004^{* *}$ & $-0.003^{*}$ \\
CEO Age & $(0.015)$ & $(0.013)$ & $(0.006)$ & $(0.020)$ & $(0.051)$ \\
& -0.011 & $-0.029^{* * *}$ & -0.011 & -0.014 & $-0.017^{* *}$ \\
MBA (0/1) & $(0.232)$ & $(0.001)$ & $(0.230)$ & $(0.110)$ & $(0.042)$ \\
& -0.002 & -0.002 & -0.003 & -0.002 & -0.003 \\
Founder (0/1) & $(0.319)$ & $(0.416)$ & $(0.207)$ & $(0.266)$ & $(0.195)$ \\
& -0.005 & -0.005 & -0.004 & -0.005 & -0.003 \\
\# Functional Areas & $(0.183)$ & $(0.164)$ & $(0.221)$ & $(0.174)$ & $(0.410)$ \\
& -0.001 & -0.001 & -0.001 & -0.001 & -0.001 \\
Has Finance Background (0/1) & $(0.555)$ & $(0.527)$ & $(0.387)$ & $(0.369)$ & $(0.349)$ \\
& $-0.005^{*}$ & -0.004 & $-0.005 *$ & $-0.005^{*}$ & -0.004 \\
Constant & $(0.099)$ & $(0.117)$ & $(0.095)$ & $(0.089)$ & $(0.134)$ \\
& $0.131^{* * *}$ & $0.204^{* * *}$ & $0.126^{* * *}$ & $0.123^{* * *}$ & $0.128^{* * *}$ \\
Year Dummies & $(0.000)$ & $(0.000)$ & $(0.001)$ & $(0.001)$ & $(0.000)$ \\
Industry Dummies & Yes & Yes & Yes & Yes & Yes \\
Observations & Yes & Yes & Yes & Yes & Yes \\
Adjusted R-squared & 5029 & 5029 & 5029 & 5029 & 5029 \\
& 0.513 & 0.510 & 0.514 & 0.521 & 0.530 \\
Hansen's J-test (p-value) & & & & & \\
First-stage Instrumental Variables' Joint & 0.858 & 0.749 & 0.746 & 0.690 & 0.685 \\
Significance (F-stat) & & & & & \\
\hline
\end{tabular}


Table 10. CEO Employment History and R\&D Intensity

This table presents IV/2SLS results for R\&D intensity on a sample of 4912 firm years. The dependent variable is R\&D intensity. Refer to Table 1 and Appendix A for variable definitions. Pre-turnover R\&D Intensity is the firm's R\&D Intensity in the year before the CEO turnover year. Instrumental variables are the unemployment rate for the year when the CEO started his first full-time job, non-business career dummy that equals one if the CEO had academic or government jobs, and the number of years the CEO has worked in his current firm's industry. The instrumental variable for CEO employment history*Industry Homogeneity in the R\&D regression is the unemployment rate described above multiplied by industry homogeneity. I report p-values of Hansen's J-test and first-stage $F$-stat at the bottom of the table. The values of the five CEO employment history proxies in the IV/2SLS estimations are predicted values. I report $p$-values based on robust standard errors clustered at the firm level in parenthesis. ${ }^{* *}, * *$, and $*$ indicate significance at the 1,5 , and $10 \%$ levels, respectively.

\begin{tabular}{|c|c|c|c|c|c|}
\hline \multirow{2}{*}{\multicolumn{6}{|c|}{ CEO Employment History Variables }} \\
\hline & & & & & \\
\hline \# Employers & $\begin{array}{c}-0.013 * * \\
(0.016)\end{array}$ & & & & \\
\hline \# Employer Changes per year & & $\begin{array}{c}-0.191 * * \\
(0.021)\end{array}$ & & & \\
\hline Employer Change Recency & & & $\begin{array}{c}-0.031 * \\
(0.063)\end{array}$ & & \\
\hline Firm Experience Diversification & & & & $\begin{array}{c}0.092 * * \\
(0.042)\end{array}$ & \\
\hline Industry Experience Diversification & & & & & $\begin{array}{c}0.025^{* *} \\
(0.027)\end{array}$ \\
\hline $\begin{array}{l}\text { CEO Emp. History * Industry } \\
\text { Homogeneity } \\
\text { Firm Characteristics }\end{array}$ & $\begin{array}{l}0.054 * * \\
(0.039)\end{array}$ & $\begin{array}{c}0.557 \\
(0.115)\end{array}$ & $\begin{array}{l}0.146^{*} \\
(0.094)\end{array}$ & $\begin{array}{c}-0.403^{*} \\
(0.071)\end{array}$ & $\begin{array}{c}-0.081 \\
(0.119)\end{array}$ \\
\hline Pre-turnover R\&D Intensity & $\begin{array}{c}0.556 * * * \\
(0.000)\end{array}$ & $\begin{array}{c}0.549 * * * \\
(0.000)\end{array}$ & $\begin{array}{c}0.570^{* * *} \\
(0.000)\end{array}$ & $\begin{array}{c}0.557 * * * \\
(0.000)\end{array}$ & $\begin{array}{c}0.539 * * * \\
(0.000)\end{array}$ \\
\hline Industry Homogeneity & $\begin{array}{c}-0.163 * * \\
(0.048)\end{array}$ & $\begin{array}{l}-0.049 \\
(0.239)\end{array}$ & $\begin{array}{l}-0.153 \\
(0.108)\end{array}$ & $\begin{array}{l}0.231^{*} \\
(0.063)\end{array}$ & $\begin{array}{l}0.067 * \\
(0.073)\end{array}$ \\
\hline $\ln$ (Total Sales) & $\begin{array}{c}-0.002 * * \\
(0.043)\end{array}$ & $\begin{array}{c}-0.002 * * * \\
(0.007)\end{array}$ & $\begin{array}{l}-0.001 \\
(0.224)\end{array}$ & $\begin{array}{l}-0.001 * \\
(0.089)\end{array}$ & $\begin{array}{c}-0.002 * * \\
(0.011)\end{array}$ \\
\hline Firm Age & $\begin{array}{c}-0.003 * * \\
(0.011)\end{array}$ & $\begin{array}{c}-0.004 * * * \\
(0.002)\end{array}$ & $\begin{array}{c}-0.003 * * \\
(0.041)\end{array}$ & $\begin{array}{c}-0.003 * * \\
(0.033)\end{array}$ & $\begin{array}{c}-0.003 * * * \\
(0.008)\end{array}$ \\
\hline Surplus Cash & $\begin{array}{c}0.120 * * * \\
(0.000)\end{array}$ & $\begin{array}{c}0.123 * * * \\
(0.000)\end{array}$ & $\begin{array}{c}0.117 * * * \\
(0.000)\end{array}$ & $\begin{array}{c}0.121 * * * \\
(0.000)\end{array}$ & $\begin{array}{c}0.127 * * * \\
(0.000)\end{array}$ \\
\hline Tobin's Q & $\begin{array}{l}-0.000 \\
(0.703)\end{array}$ & $\begin{array}{l}-0.000 \\
(0.668)\end{array}$ & $\begin{array}{l}-0.000 \\
(0.824)\end{array}$ & $\begin{array}{l}-0.000 \\
(0.755)\end{array}$ & $\begin{array}{c}-0.001 \\
(0.652)\end{array}$ \\
\hline Advertising/Total Assets & $\begin{array}{c}-0.031 \\
(0.423)\end{array}$ & $\begin{array}{l}-0.020 \\
(0.584)\end{array}$ & $\begin{array}{l}-0.039 \\
(0.340)\end{array}$ & $\begin{array}{l}-0.024 \\
(0.548)\end{array}$ & $\begin{array}{l}-0.018 \\
(0.609)\end{array}$ \\
\hline CAPEXP/Total Assets & $\begin{array}{l}-0.005 \\
(0.773)\end{array}$ & $\begin{array}{l}-0.010 \\
(0.548)\end{array}$ & $\begin{array}{l}-0.011 \\
(0.613)\end{array}$ & $\begin{array}{l}-0.010 \\
(0.592)\end{array}$ & $\begin{array}{l}-0.004 \\
(0.817)\end{array}$ \\
\hline Leverage & $\begin{array}{c}0.006 \\
(0.296)\end{array}$ & $\begin{array}{c}0.009^{* *} \\
(0.035)\end{array}$ & $\begin{array}{c}-0.000 \\
(0.980)\end{array}$ & $\begin{array}{c}0.005 \\
(0.388)\end{array}$ & $\begin{array}{c}0.009 * * \\
(0.027)\end{array}$ \\
\hline $\begin{array}{l}\text { Pay Directors Equity Based } \\
\text { Compensation }(0 / 1)\end{array}$ & $\begin{array}{c}0.002 \\
(0.156)\end{array}$ & $\begin{array}{c}0.002 \\
(0.137)\end{array}$ & $\begin{array}{c}0.002 \\
(0.293)\end{array}$ & $\begin{array}{c}0.002 \\
(0.191)\end{array}$ & $\begin{array}{c}0.002 \\
(0.119)\end{array}$ \\
\hline Activist Institutional Holding (\%) & $\begin{array}{c}0.063 \\
(0.156)\end{array}$ & $\begin{array}{c}0.053 \\
(0.221)\end{array}$ & $\begin{array}{c}0.066 \\
(0.170)\end{array}$ & $\begin{array}{l}0.080^{*} \\
(0.078)\end{array}$ & $\begin{array}{c}0.064 \\
(0.130)\end{array}$ \\
\hline CEO Cash Compensation & $\begin{array}{c}0.007 * * * \\
(0.001)\end{array}$ & $\begin{array}{c}0.006^{* * * *} \\
(0.003)\end{array}$ & $\begin{array}{c}0.008^{* * *} \\
(0.002)\end{array}$ & $\begin{array}{c}0.006 * * * \\
(0.004)\end{array}$ & $\begin{array}{c}0.005 * * * \\
(0.005)\end{array}$ \\
\hline CEO Compensation Delta & $\begin{array}{l}-0.000 \\
(0.744)\end{array}$ & $\begin{array}{l}-0.001 \\
(0.244)\end{array}$ & $\begin{array}{l}-0.000 \\
(0.863)\end{array}$ & $\begin{array}{l}-0.000 \\
(0.831)\end{array}$ & $\begin{array}{l}-0.001 \\
(0.180)\end{array}$ \\
\hline CEO Compensation Vega & $\begin{array}{c}0.003 \\
(0.203)\end{array}$ & $\begin{array}{l}0.005^{* *} \\
(0.017)\end{array}$ & $\begin{array}{c}0.002 \\
(0.456)\end{array}$ & $\begin{array}{c}0.003 \\
(0.213)\end{array}$ & $\begin{array}{l}0.004^{* *} \\
(0.038)\end{array}$ \\
\hline Herfindhal Index & $\begin{array}{l}-0.006 \\
(0.821)\end{array}$ & $\begin{array}{l}-0.007 \\
(0.764)\end{array}$ & $\begin{array}{c}0.018 \\
(0.643)\end{array}$ & $\begin{array}{l}-0.014 \\
(0.582)\end{array}$ & $\begin{array}{l}-0.012 \\
(0.618)\end{array}$ \\
\hline
\end{tabular}


Table 10 Continued

\begin{tabular}{lccccc} 
CEO Characteristics & & & & & \\
& -0.000 & -0.000 & -0.000 & -0.000 & 0.001 \\
Ln(CEO Tenure+1) & $(0.768)$ & $(0.901)$ & $(0.822)$ & $(0.835)$ & $(0.506)$ \\
CEO Age & -0.012 & $-0.024^{* * *}$ & -0.013 & $-0.019^{* *}$ & $-0.016^{* *}$ \\
& $(0.107)$ & $(0.001)$ & $(0.108)$ & $(0.019)$ & $(0.014)$ \\
MBA (0/1) & 0.002 & 0.002 & 0.001 & 0.002 & 0.002 \\
& $(0.21)$ & $(0.189)$ & $(0.463)$ & $(0.250)$ & $(0.351)$ \\
Founder (0/1) & -0.005 & $-0.007^{* *}$ & -0.003 & -0.004 & $-0.005^{*}$ \\
& $(0.168)$ & $(0.023)$ & $(0.445)$ & $(0.351)$ & $(0.058)$ \\
\# Functional Areas & 0.001 & 0.001 & 0.001 & 0.001 & 0.001 \\
& $(0.382)$ & $(0.426)$ & $(0.515)$ & $(0.393)$ & $(0.514)$ \\
Has Finance Background (0/1) & $-0.006^{* * *}$ & $-0.005^{* * *}$ & $-0.007^{* * *}$ & $-0.008^{* * *}$ & $-0.005^{* * *}$ \\
& $(0.001)$ & $(0.001)$ & $(0.003)$ & $(0.001)$ & $(0.001)$ \\
Constant & $0.106^{* * *}$ & $0.143^{* * *}$ & $0.099^{* * *}$ & 0.032 & $0.066^{* *}$ \\
& $(0.001)$ & $(0.000)$ & $(0.005)$ & $(0.453)$ & $(0.020)$ \\
Year Dummies & Yes & Yes & Yes & Yes & Yes \\
& Yes & Yes & Yes & Yes & Yes \\
Observations & 4912 & 4912 & 4912 & 4912 & 4912 \\
Adjusted R-squared & 0.745 & 0.763 & 0.702 & 0.729 & 0.771 \\
& & & & & \\
Hansen's J-test (p-value) & 0.379 & 0.255 & 0.547 & 0.591 & 0.268 \\
First-stage Joint Sig. for CEO Emp. & & & & & \\
History Variable (F-stat) & 40.65 & 54.26 & 43.25 & 66.26 & 207.32 \\
First-stage Joint Sig. for CEO Emp. & & & & & \\
His. * Ind. Homogeneity (F-Stat) & 27.07 & 42.16 & 32.18 & 53.29 & 139.54 \\
\hline
\end{tabular}




\section{Table 11. CEO Employment History and Advertising Intensity}

This table presents IV/2SLS results for investments in advertising for 5,074 firm years. The dependent variable is advertising divided by total assets. Refer to Table 1 and Appendix A for variable definitions. Pre-turnover Adv. Intensity is the firm's advertising intensity in the year before the CEO turnover year. Instrumental variables are the unemployment rate for the year when the CEO started his first full-time job, non-business career dummy that equals one if the CEO had academic or government jobs, and the number of years the CEO has worked in his current firm's industry. I report p-values of Hansen's J-test and first-stage $F$-stat at the bottom of the table. The values of the five CEO employment history proxies in the IV/2SLS estimations are predicted values. The predicted signs for the CEO employment history proxies are presented in parenthesis at the beginning of each row. I report $p$-values based on robust standard errors clustered at the firm level in parenthesis. $* * *, * *$, and * indicate significance at the 1,5 , and $10 \%$ levels, respectively.

$\begin{array}{lllll}(1) & (2) & (3) & (4) & \text { (5) }\end{array}$

CEO Employment History Proxies

\# Employers
\# Employer Changes per year
Firm Experience Diversification

\section{Firm Characteristics}

Pre-turnover Adv. Intensity

$\ln$ (Total Sales)

Firm Age

Surplus Cash

Tobin's Q

R\&D Exp./Total Assets

CAPEXP/Total Assets

Leverage

Pay Directors Equity Based

Compensation (0/1)

Activist Institutional Holding (\%)

CEO Cash Compensation

CEO Compensation Delta

CEO Compensation Vega

Herfindhal Index

\section{$0.001 *$} $(0.072)$

$(+)$

$(+)$

(-)

(-)
$0.041 *$

(0.076)

$$
\begin{aligned}
& 0.002 * \\
& (0.080)
\end{aligned}
$$$$
-0.007^{*}
$$$$
\text { (0.085) }
$$

$-0.004$

\begin{tabular}{|c|c|c|c|c|}
\hline $\begin{array}{c}0.543 * * * \\
(0.000)\end{array}$ & $\begin{array}{c}0.544 * * * \\
(0.000)\end{array}$ & $\begin{array}{c}0.543 * * * \\
(0.000)\end{array}$ & $\begin{array}{c}0.543 * * * \\
(0.000)\end{array}$ & $\begin{array}{c}0.544 * * * \\
(0.000)\end{array}$ \\
\hline $0.001 *$ & $0.001 *$ & $0.001 *$ & $0.001 *$ & 0.000 \\
\hline$(0.067)$ & $(0.062)$ & $(0.086)$ & $(0.084)$ & $(0.181)$ \\
\hline 0.001 & 0.001 & 0.001 & 0.001 & 0.000 \\
\hline$(0.344)$ & $(0.284)$ & $(0.357)$ & $(0.256)$ & $(0.501)$ \\
\hline-0.011 & -0.011 & -0.011 & -0.011 & -0.012 \\
\hline$(0.251)$ & $(0.266)$ & $(0.263)$ & $(0.250)$ & $(0.228)$ \\
\hline $0.001 * * *$ & $0.001 * * *$ & $0.001 * * *$ & $0.001 * *$ & $0.001 * * *$ \\
\hline$(0.008)$ & (0.009) & $(0.009)$ & $(0.010)$ & $(0.010)$ \\
\hline 0.005 & 0.004 & 0.004 & 0.004 & 0.004 \\
\hline$(0.764)$ & $(0.790)$ & $(0.818)$ & $(0.778)$ & $(0.773)$ \\
\hline $0.017^{*}$ & $0.016^{*}$ & $0.016^{*}$ & $0.017 *$ & $0.017 *$ \\
\hline$(0.083)$ & $(0.089)$ & $(0.093)$ & $(0.080)$ & $(0.080)$ \\
\hline$-0.006^{*}$ & $-0.007 *$ & $-0.006^{*}$ & $-0.006^{*}$ & $-0.006^{*}$ \\
\hline$(0.057)$ & $(0.056)$ & $(0.058)$ & $(0.060)$ & $(0.066)$ \\
\hline 0.002 & 0.002 & 0.002 & 0.002 & $0.002 *$ \\
\hline$(0.107)$ & $(0.101)$ & $(0.104)$ & $(0.105)$ & $(0.091)$ \\
\hline-0.013 & -0.011 & -0.013 & -0.013 & -0.014 \\
\hline$(0.747)$ & $(0.769)$ & $(0.740)$ & $(0.730)$ & $(0.727)$ \\
\hline $0.002 * *$ & $0.002 * *$ & $0.002 * *$ & $0.003 * *$ & $0.002 * *$ \\
\hline$(0.036)$ & $(0.032)$ & $(0.039)$ & $(0.025)$ & $(0.034)$ \\
\hline 0.001 & 0.001 & 0.001 & 0.001 & 0.001 \\
\hline$(0.221)$ & $(0.219)$ & $(0.234)$ & $(0.193)$ & $(0.195)$ \\
\hline-0.002 & -0.002 & -0.002 & -0.002 & -0.002 \\
\hline$(0.261)$ & $(0.232)$ & $(0.290)$ & $(0.236)$ & $(0.294)$ \\
\hline 0.028 & 0.027 & 0.026 & 0.029 & 0.027 \\
\hline$(0.202)$ & $(0.214)$ & $(0.236)$ & $(0.173)$ & $(0.208)$ \\
\hline
\end{tabular}

(0.126) 
Table 11 Continued.

\begin{tabular}{lccccc}
\hline CEO Characteristics & & & & & \\
Ln(CEO Tenure+1) & -0.001 & -0.001 & -0.001 & $-0.001^{*}$ & $-0.001^{* *}$ \\
CEO Age & $(0.131)$ & $(0.155)$ & $(0.277)$ & $(0.086)$ & $(0.039)$ \\
& -0.004 & 0.003 & -0.003 & -0.002 & -0.001 \\
MBA (0/1) & $(0.421)$ & $(0.563)$ & $(0.429)$ & $(0.551)$ & $(0.795)$ \\
& -0.001 & -0.001 & -0.001 & -0.001 & -0.001 \\
Founder (0/1) & $(0.387)$ & $(0.328)$ & $(0.477)$ & $(0.407)$ & $(0.483)$ \\
& -0.002 & -0.002 & -0.002 & -0.002 & -0.003 \\
\# Functional Areas & $(0.365)$ & $(0.409)$ & $(0.312)$ & $(0.372)$ & $(0.168)$ \\
& -0.001 & -0.001 & -0.000 & -0.000 & -0.000 \\
Has Finance Background (0/1) & $(0.327)$ & $(0.330)$ & $(0.397)$ & $(0.396)$ & $(0.418)$ \\
& -0.001 & -0.001 & -0.001 & -0.001 & -0.001 \\
Constant & $(0.437)$ & $(0.413)$ & $(0.440)$ & $(0.439)$ & $(0.396)$ \\
& 0.008 & -0.017 & 0.009 & 0.010 & 0.007 \\
Year Dummies & $(0.682)$ & $(0.404)$ & $(0.636)$ & $(0.601)$ & $(0.711)$ \\
Industry Dummies & Yes & Yes & Yes & Yes & Yes \\
Observations & Yes & Yes & Yes & Yes & Yes \\
Adjusted R-squared & 5074 & 5074 & 5074 & 5074 & 5074 \\
& 0.633 & 0.632 & 0.634 & 0.635 & 0.636 \\
Hansen's J-test (p-value) & & & & & \\
First-stage Instrumental Variables' Joint & 0.632 & 0.639 & 0.582 & 0.711 & 0.592 \\
Significance (F-stat) & & & & & \\
\hline
\end{tabular}




\section{Table 12. Simultaneous Equations: CEO Employment History, Leverage, and Investment Policies}

This table presents 3SLS results for a system of five equations. The dependent variables are listed at the top of each column. Refer to Section 5.3.5 for details on the five equations. Refer to Table 1 and Appendix A for variable definitions. Pre-turnover firm policies are the respective firm policies in the year before the CEO turnover year. The predicted signs for the CEO employment history proxies are presented in parenthesis at the top of each row. Panel A presents results on the whole sample and Panel B presents results on a subsample of firms with an industry homogeneity value of 0.26 and above. I report $p$-values based on robust standard errors clustered at the firm level in parenthesis. $* * *, * *$, and $*$ indicate significance at the 1,5 , and $10 \%$ levels, respectively.

Panel A: Whole Sample (4,696 Obs.)

\begin{tabular}{|c|c|c|c|c|c|}
\hline & Leverage & CAPEXP & R\&D/Total Assets & Adv./Total Assets & \# Employers \\
\hline \multicolumn{6}{|c|}{ CEO Employment History Proxies } \\
\hline \multirow{3}{*}{ \# Employers } & $(+)$ & $(-)$ & $(+)$ & $(+)$ & \\
\hline & $0.011 * * *$ & $-0.004 * * *$ & $-0.003 * * *$ & $0.001 * * *$ & \\
\hline & $(0.001)$ & $(0.000)$ & $(0.000)$ & $(0.001)$ & \\
\hline \multicolumn{6}{|l|}{ Firm Policies } \\
\hline \multirow[t]{2}{*}{ CAPEXP } & $-1.839 * * *$ & & $-0.075^{* * *}$ & $0.094 * * *$ & $-11.531 * * *$ \\
\hline & $(0.000)$ & & $(0.000)$ & $(0.000)$ & $(0.000)$ \\
\hline \multirow[t]{2}{*}{$\mathrm{R} \& \mathrm{D} /$ Total Assets } & $-0.517 * * *$ & $-0.108 * * *$ & & 0.008 & $4.550 * * *$ \\
\hline & $(0.000)$ & $(0.000)$ & & $(0.418)$ & $(0.000)$ \\
\hline \multirow[t]{2}{*}{ Adv./Total Assets } & -0.143 & 0.046 & 0.010 & & $3.091 * *$ \\
\hline & $(0.243)$ & $(0.137)$ & $(0.666)$ & & $(0.015)$ \\
\hline \multirow[t]{2}{*}{ Leverage } & & 0.011 & $0.061 * * *$ & -0.001 & $2.498 * * *$ \\
\hline & & $(0.146)$ & $(0.000)$ & $(0.822)$ & $(0.000)$ \\
\hline \multicolumn{6}{|l|}{ Firm Characteristics } \\
\hline \multirow[t]{2}{*}{ Pre-turnover Policy } & $0.309 * * *$ & $0.316^{* * *}$ & $0.584 * * *$ & $0.550 * * *$ & \\
\hline & $(0.000)$ & $(0.000)$ & $(0.000)$ & $(0.000)$ & \\
\hline \multirow[t]{2}{*}{ Unemployment Rate } & & & & & $-0.027 *$ \\
\hline & & & & & $(0.072)$ \\
\hline \multirow{2}{*}{$\begin{array}{l}\text { Has Non-business Career } \\
(0 / 1)\end{array}$} & & & & & $0.181 * * *$ \\
\hline & & & & & $(0.007)$ \\
\hline \multirow{2}{*}{$\begin{array}{l}\text { \#Years working in the } \\
\text { current firm's industry }\end{array}$} & & & & & $-0.066 * * *$ \\
\hline & & & & & $(0.000)$ \\
\hline \multirow[t]{2}{*}{$\ln$ (Total Sales) } & $0.019 * * *$ & $-0.003 * * *$ & $-0.004 * * *$ & $0.001 * *$ & $-0.284 * * *$ \\
\hline & $(0.000)$ & $(0.000)$ & $(0.000)$ & $(0.036)$ & $(0.000)$ \\
\hline \multirow[t]{2}{*}{ Firm Age } & $-0.011 * *$ & $-0.002 * *$ & $-0.004 * * *$ & $0.002 * * *$ & $-0.209 * * *$ \\
\hline & $(0.013)$ & $(0.031)$ & $(0.000)$ & $(0.001)$ & $(0.000)$ \\
\hline \multirow{2}{*}{$\begin{array}{l}\text { Operating Return on } \\
\text { Assets }\end{array}$} & $-0.545^{* * *}$ & & & & $2.403 * * *$ \\
\hline & $(0.000)$ & & & & $(0.000)$ \\
\hline \multirow[t]{2}{*}{ Surplus Cash } & & $0.037 * * *$ & $0.133 * * *$ & -0.007 & \\
\hline & & $(0.000)$ & $(0.000)$ & $(0.216)$ & \\
\hline \multirow[t]{2}{*}{ Tobin's Q } & $-0.011 * * *$ & $0.004 * * *$ & $0.002 * * *$ & $0.001 * * *$ & -0.017 \\
\hline & $(0.000)$ & $(0.000)$ & $(0.000)$ & $(0.000)$ & $(0.531)$ \\
\hline
\end{tabular}


Table 12 Continued.

\begin{tabular}{|c|c|c|c|c|c|}
\hline \multicolumn{6}{|c|}{ Firm Characteristics (Continued) } \\
\hline Capital Intensity & $\begin{array}{c}0.379 * * * \\
(0.000)\end{array}$ & & & & \\
\hline $\begin{array}{l}\text { Depreciation/Total } \\
\text { Assets }\end{array}$ & $\begin{array}{c}2.307 * * * \\
(0.000)\end{array}$ & & & & \\
\hline $\begin{array}{l}\text { Pay Directors Equity } \\
\text { Based Compensation }\end{array}$ & $\begin{array}{c}0.016^{* * *} \\
(0.003)\end{array}$ & $\begin{array}{l}-0.001 \\
(0.624)\end{array}$ & $\begin{array}{c}0.001 \\
(0.426)\end{array}$ & $\begin{array}{c}0.002 * * * \\
(0.005)\end{array}$ & $\begin{array}{l}-0.031 \\
(0.601)\end{array}$ \\
\hline $\begin{array}{l}\text { Act. Institutional Hldg. } \\
(\%)\end{array}$ & $\begin{array}{l}-0.244 \\
(0.127)\end{array}$ & $\begin{array}{l}-0.055 \\
(0.181)\end{array}$ & $\begin{array}{l}0.077^{* *} \\
(0.011)\end{array}$ & $\begin{array}{l}-0.004 \\
(0.841)\end{array}$ & $\begin{array}{l}-1.879 \\
(0.267)\end{array}$ \\
\hline $\begin{array}{l}\text { CEO Cash } \\
\text { Compensation }\end{array}$ & $\begin{array}{c}0.009 \\
(0.206)\end{array}$ & $\begin{array}{l}-0.003^{*} \\
(0.055)\end{array}$ & $\begin{array}{l}0.003 * * \\
(0.014)\end{array}$ & $\begin{array}{c}0.002 * * \\
(0.013)\end{array}$ & $\begin{array}{l}-0.055 \\
(0.459)\end{array}$ \\
\hline $\begin{array}{l}\text { CEO Compensation } \\
\text { Delta }\end{array}$ & $\begin{array}{l}-0.003 \\
(0.415)\end{array}$ & $\begin{array}{c}-0.002 * * \\
(0.047)\end{array}$ & $\begin{array}{l}-0.001 \\
(0.201)\end{array}$ & $\begin{array}{c}0.001 * * * \\
(0.009)\end{array}$ & $\begin{array}{c}0.003 \\
(0.923)\end{array}$ \\
\hline $\begin{array}{l}\text { CEO Compensation } \\
\text { Vega }\end{array}$ & $\begin{array}{c}-0.022 * * * \\
(0.003)\end{array}$ & $\begin{array}{c}0.000 \\
(0.836)\end{array}$ & $\begin{array}{c}0.006^{* * *} \\
(0.000)\end{array}$ & $\begin{array}{l}-0.002 * \\
(0.060)\end{array}$ & $\begin{array}{c}0.222 * * * \\
(0.004)\end{array}$ \\
\hline Herfindhal Index & $\begin{array}{c}0.203 \\
(0.150)\end{array}$ & $\begin{array}{l}-0.061^{*} \\
(0.090)\end{array}$ & $\begin{array}{c}-0.070 * * * \\
(0.008)\end{array}$ & $\begin{array}{c}0.022 \\
(0.221)\end{array}$ & $\begin{array}{l}-1.174 \\
(0.426)\end{array}$ \\
\hline$\underline{\text { CEO Characteristics }}$ & & & & & \\
\hline $\operatorname{Ln}($ Ceo Tenure +1$)$ & $\begin{array}{l}0.008 * * \\
(0.031)\end{array}$ & $\begin{array}{c}-0.003 * * * \\
(0.006)\end{array}$ & $\begin{array}{l}-0.001 \\
(0.316)\end{array}$ & $\begin{array}{c}-0.002 * * * \\
(0.000)\end{array}$ & $\begin{array}{c}-0.119 * * * \\
(0.001)\end{array}$ \\
\hline CEO Age & $\begin{array}{c}-0.105^{* * *} \\
(0.000)\end{array}$ & $\begin{array}{l}-0.009^{*} \\
(0.056)\end{array}$ & $\begin{array}{c}-0.012 * * * \\
(0.001)\end{array}$ & $\begin{array}{c}0.001 \\
(0.550)\end{array}$ & $\begin{array}{c}3.322 * * * \\
(0.000)\end{array}$ \\
\hline $\operatorname{MBA}(0 / 1)$ & $\begin{array}{c}0.017 * * * \\
(0.000)\end{array}$ & $\begin{array}{l}-0.002 \\
(0.145)\end{array}$ & $\begin{array}{l}-0.000 \\
(0.975)\end{array}$ & $\begin{array}{l}-0.001 \\
(0.175)\end{array}$ & $\begin{array}{c}0.121 * * * \\
(0.007)\end{array}$ \\
\hline Founder $(0 / 1)$ & $\begin{array}{c}0.020 * * * \\
(0.006)\end{array}$ & $\begin{array}{c}-0.006^{* * *} \\
(0.002)\end{array}$ & $\begin{array}{c}-0.008 * * * \\
(0.000)\end{array}$ & $\begin{array}{l}-0.001 \\
(0.118)\end{array}$ & $\begin{array}{c}-0.908 * * * \\
(0.000)\end{array}$ \\
\hline \# Functional Areas & $\begin{array}{l}-0.004 \\
(0.122)\end{array}$ & $\begin{array}{l}-0.001 * \\
(0.067)\end{array}$ & $\begin{array}{c}0.001 \\
(0.139)\end{array}$ & $\begin{array}{l}-0.000 \\
(0.570)\end{array}$ & $\begin{array}{c}0.150 * * * \\
(0.000)\end{array}$ \\
\hline $\begin{array}{l}\text { Has Fin. Background } \\
(0 / 1)\end{array}$ & $\begin{array}{c}0.020 * * * \\
(0.000)\end{array}$ & $\begin{array}{c}-0.005 * * * \\
(0.000)\end{array}$ & $\begin{array}{c}-0.006^{* * *} \\
(0.000)\end{array}$ & $\begin{array}{l}-0.001 \\
(0.204)\end{array}$ & $\begin{array}{l}-0.053 \\
(0.313)\end{array}$ \\
\hline Constant & $\begin{array}{l}0.262 * * \\
(0.011)\end{array}$ & $\begin{array}{c}0.108 * * * \\
(0.000)\end{array}$ & $\begin{array}{c}0.095 * * * \\
(0.000)\end{array}$ & $\begin{array}{l}-0.023 * \\
(0.059)\end{array}$ & $\begin{array}{c}-7.184 * * * \\
(0.000)\end{array}$ \\
\hline Year Dummies & Yes & Yes & Yes & Yes & Yes \\
\hline Industry Dummies & Yes & Yes & Yes & Yes & Yes \\
\hline Observations & 4696 & 4696 & 4696 & 4696 & 4696 \\
\hline R-squared & 0.482 & 0.529 & 0.756 & 0.638 & 0.344 \\
\hline
\end{tabular}


Table 12 Continued.

Panel B: Subsample: Homogenous Industries (Industry Homogeneity>=0.26)

\begin{tabular}{|c|c|c|c|c|c|}
\hline & Leverage & CAPEXP & R\&D/Total Assets & Adv./Total Assets & \# Employers \\
\hline \multicolumn{6}{|c|}{$\underline{\text { CEO Employment History Proxies }}$} \\
\hline \multirow{3}{*}{ \# Employers } & $(+)$ & $(-)$ & $(+)$ & $(+)$ & \\
\hline & $0.013 *$ & $-0.006 * * *$ & $0.000 *$ & $0.006 * * *$ & \\
\hline & $(0.083)$ & $(0.001)$ & $(0.069)$ & $(0.000)$ & \\
\hline \multicolumn{6}{|l|}{ Firm Policies } \\
\hline \multirow[t]{2}{*}{ R\&D/Total Assets } & 0.404 & & $-0.015 * * *$ & $0.133 * * *$ & $-7.377 * * *$ \\
\hline & $(0.322)$ & & $(0.001)$ & $(0.000)$ & $(0.000)$ \\
\hline \multirow[t]{2}{*}{ Adv./Total Assets } & -0.085 & $-0.617 * * *$ & & 0.082 & $-7.615^{*}$ \\
\hline & $(0.839)$ & $(0.000)$ & & $(0.106)$ & $(0.093)$ \\
\hline \multirow[t]{2}{*}{ CAPEXP } & $-0.660 * * *$ & 0.064 & $-0.019 * *$ & & $8.971 * * *$ \\
\hline & $(0.003)$ & $(0.348)$ & $(0.018)$ & & $(0.000)$ \\
\hline \multirow[t]{2}{*}{ Leverage } & & -0.004 & -0.001 & -0.005 & 0.894 \\
\hline & & $(0.767)$ & $(0.727)$ & $(0.535)$ & $(0.160)$ \\
\hline \multicolumn{6}{|l|}{$\underline{\text { Firm Characteristics }}$} \\
\hline \multirow[t]{2}{*}{ Pre-turnover Policy } & $0.342 * * *$ & $0.372 * * *$ & $0.828 * * *$ & $0.752 * * *$ & \\
\hline & $(0.000)$ & $(0.000)$ & $(0.000)$ & $(0.000)$ & \\
\hline \multirow[t]{2}{*}{ Unemployment Rate } & & & & & $-0.115 * * *$ \\
\hline & & & & & $(0.000)$ \\
\hline \multirow{2}{*}{$\begin{array}{l}\text { Has Non-business Career } \\
(0 / 1)\end{array}$} & & & & & 0.090 \\
\hline & & & & & $(0.405)$ \\
\hline \multirow{2}{*}{$\begin{array}{l}\text { \# Years working in the } \\
\text { current firm's industry }\end{array}$} & & & & & $-0.055 * * *$ \\
\hline & & & & & $(0.000)$ \\
\hline \multirow[t]{2}{*}{$\ln$ (Total Sales) } & $0.035 * * *$ & $-0.009 * * *$ & -0.000 & $0.003 * * *$ & $-0.408 * * *$ \\
\hline & $(0.000)$ & $(0.000)$ & $(0.651)$ & $(0.000)$ & $(0.000)$ \\
\hline \multirow[t]{2}{*}{ Firm Age } & $-0.030 * * *$ & -0.001 & 0.000 & $0.004 * * *$ & -0.101 \\
\hline & $(0.000)$ & $(0.550)$ & $(0.555)$ & $(0.000)$ & $(0.174)$ \\
\hline \multirow{2}{*}{$\begin{array}{l}\text { Operating Return on } \\
\text { Assets }\end{array}$} & $-0.951^{* * *}$ & & & & 1.717 \\
\hline & $(0.000)$ & & & & $(0.110)$ \\
\hline \multirow[t]{2}{*}{ Surplus Cash } & & $0.043 * *$ & $0.007 * * *$ & $-0.032 * *$ & \\
\hline & & $(0.030)$ & $(0.003)$ & $(0.010)$ & \\
\hline \multirow[t]{2}{*}{ Tobin's Q } & $-0.030 * * *$ & $0.004 *$ & 0.000 & $0.002 * *$ & $-0.187 * * *$ \\
\hline & $(0.000)$ & $(0.056)$ & $(0.681)$ & $(0.012)$ & $(0.004)$ \\
\hline \multirow[t]{2}{*}{ Capital Intensity } & $0.077 * *$ & & & & \\
\hline & $(0.041)$ & & & & \\
\hline \multirow{2}{*}{$\begin{array}{l}\text { Depreciation/Total } \\
\text { Assets }\end{array}$} & 0.396 & & & & \\
\hline & $(0.328)$ & & & & \\
\hline Pay Directors Equity & 0.015 & 0.002 & -0.000 & 0.001 & 0.075 \\
\hline Based Compensation & $(0.172)$ & $(0.612)$ & $(0.805)$ & $(0.405)$ & $(0.532)$ \\
\hline
\end{tabular}


Table 12 Continued.

\begin{tabular}{|c|c|c|c|c|c|}
\hline \multicolumn{6}{|l|}{ Act. Institutional Hldg. } \\
\hline & $(0.098)$ & $(0.932)$ & $(0.032)$ & $(0.107)$ & $(0.175)$ \\
\hline \multirow{2}{*}{$\begin{array}{l}\text { CEO Cash } \\
\text { Compensation }\end{array}$} & $0.048 * * *$ & $-0.013 * * *$ & 0.000 & $0.005^{* * *}$ & $-0.509 * * *$ \\
\hline & $(0.000)$ & $(0.003)$ & $(0.544)$ & $(0.001)$ & $(0.000)$ \\
\hline \multirow{2}{*}{$\begin{array}{l}\text { CEO Compensation } \\
\text { Delta }\end{array}$} & -0.004 & -0.001 & -0.000 & -0.000 & -0.069 \\
\hline & $(0.527)$ & $(0.716)$ & $(0.469)$ & $(0.490)$ & $(0.262)$ \\
\hline \multirow{2}{*}{$\begin{array}{l}\text { CEO Compensation } \\
\text { Vega }\end{array}$} & $-0.049 * * *$ & 0.006 & $-0.002 * * *$ & -0.002 & $0.362 * * *$ \\
\hline & $(0.000)$ & $(0.104)$ & $(0.000)$ & $(0.141)$ & $(0.007)$ \\
\hline \multirow[t]{2}{*}{ Herfindhal Index } & $0.694 * * *$ & $-0.114 *$ & -0.011 & $0.084 * * *$ & -1.382 \\
\hline & $(0.000)$ & $(0.052)$ & $(0.116)$ & $(0.000)$ & $(0.488)$ \\
\hline \multicolumn{6}{|l|}{$\underline{\text { CEO Characteristics }}$} \\
\hline \multirow[t]{2}{*}{ Ln(CEO Tenure+1) } & -0.010 & 0.000 & -0.000 & $0.002 * * *$ & $-0.133^{*}$ \\
\hline & $(0.112)$ & $(0.935)$ & $(0.468)$ & $(0.002)$ & $(0.050)$ \\
\hline \multirow[t]{2}{*}{ CEO Age } & -0.060 & $-0.029 * *$ & $-0.003 * *$ & 0.005 & $1.138^{* *}$ \\
\hline & $(0.104)$ & $(0.011)$ & $(0.016)$ & $(0.272)$ & $(0.012)$ \\
\hline \multirow[t]{2}{*}{$\operatorname{MBA}(0 / 1)$} & $0.030 * * *$ & -0.004 & $-0.001 * * *$ & $0.002 * *$ & -0.109 \\
\hline & $(0.000)$ & $(0.132)$ & $(0.000)$ & $(0.044)$ & $(0.229)$ \\
\hline \multirow[t]{2}{*}{ Founder $(0 / 1)$} & 0.025 & $-0.017 * * *$ & 0.000 & $0.011 * * *$ & $-1.247 * * *$ \\
\hline & $(0.155)$ & $(0.000)$ & $(0.443)$ & $(0.000)$ & $(0.000)$ \\
\hline \multirow[t]{2}{*}{ \# Functional Areas } & $-0.012 * * *$ & -0.000 & -0.000 & $-0.002 * * *$ & $0.185 * * *$ \\
\hline & $(0.004)$ & $(0.949)$ & $(0.169)$ & $(0.000)$ & $(0.000)$ \\
\hline \multirow{2}{*}{$\begin{array}{l}\text { Has Fin. Background } \\
(0 / 1)\end{array}$} & $0.022 * *$ & $-0.006^{* *}$ & -0.000 & $0.002 * *$ & 0.149 \\
\hline & $(0.013)$ & $(0.035)$ & $(0.567)$ & $(0.034)$ & $(0.126)$ \\
\hline \multirow[t]{2}{*}{ Constant } & 0.324 & $0.217 * * *$ & $0.013^{*}$ & $-0.100 * * *$ & $4.048^{*}$ \\
\hline & $(0.131)$ & $(0.001)$ & $(0.077)$ & $(0.000)$ & $(0.094)$ \\
\hline Year Dummies & Yes & Yes & Yes & Yes & Yes \\
\hline Industry Dummies & Yes & Yes & Yes & Yes & Yes \\
\hline Observations & 1365 & 1365 & 1365 & 1365 & 1365 \\
\hline R-squared & 0.648 & 0.593 & 0.892 & 0.672 & 0.424 \\
\hline
\end{tabular}


Table 13. CEO Employment History and Total Risk

This table presents IV/2SLS results for total firm risk for a sample of 4693 firm years. The dependent variable is the annualized standard deviation of daily stock returns. Refer to Table 1 and Appendix A for variable definitions. Instrumental variables are the unemployment rate for the year when the CEO started his first full-time job, nonbusiness career dummy that equals one if the CEO had academic or government jobs, and the number of years the CEO has worked in his current firm's industry. Pre-turnover Total Risk is the firm's total risk in the year before the CEO turnover year. I report p-values of Hansen's J-test and first-stage $F$-stat at the bottom of the table. The values of the five CEO employment history proxies in the IV/2SLS estimations are predicted values. The predicted signs for the CEO employment history proxies are presented in parenthesis at the beginning of each row. I report $p$-values based on robust standard errors clustered at the firm level in parenthesis. $* * *, * *$, and $*$ indicate significance at the $\underline{1,5 \text {, and } 10 \% \text { levels, respectively. }}$

\begin{tabular}{|c|c|c|c|c|c|c|}
\hline & & $(1)$ & $(2)$ & (3) & $(4)$ & $(5)$ \\
\hline $\begin{array}{l}\text { CEO Employment History Proxies } \\
\text { \# Employers }\end{array}$ & $(+)$ & $\begin{array}{l}0.006^{*} \\
(0.062)\end{array}$ & & & & \\
\hline \# Employer Changes per year & $(+)$ & & $\begin{array}{l}0.171^{*} \\
(0.094)\end{array}$ & & & \\
\hline Employer Change Recency & $(+)$ & & & $\begin{array}{l}0.009^{*} \\
(0.061)\end{array}$ & & \\
\hline Firm Experience Diversification & $(-)$ & & & & $\begin{array}{l}-0.023 \\
(0.179)\end{array}$ & \\
\hline Industry Experience Diversification & $(-)$ & & & & & $\begin{array}{l}-0.017 \\
(0.324)\end{array}$ \\
\hline Firm Characteristics & & & & & & \\
\hline $\begin{array}{l}\text { Pre-turnover Total Risk } \\
\text { (Daily Stock Ret. Std.) }\end{array}$ & & $\begin{array}{c}0.191 * * * \\
(0.000)\end{array}$ & $\begin{array}{c}0.191 * * * \\
(0.000)\end{array}$ & $\begin{array}{c}0.191 * * * \\
(0.000)\end{array}$ & $\begin{array}{c}0.195 * * * \\
(0.000)\end{array}$ & $\begin{array}{c}0.197 * * * \\
(0.000)\end{array}$ \\
\hline $\ln$ (Total Sales) & & $\begin{array}{c}-0.018 * * * \\
(0.000)\end{array}$ & $\begin{array}{l}-0.018 * * * \\
(0.000)\end{array}$ & $\begin{array}{l}-0.019 * * * \\
(0.000)\end{array}$ & $\begin{array}{l}-0.019 * * * \\
(0.000)\end{array}$ & $\begin{array}{c}-0.019 * * * \\
(0.000)\end{array}$ \\
\hline Firm Age & & $\begin{array}{c}-0.020 * * * \\
(0.000)\end{array}$ & $\begin{array}{l}-0.020 * * * \\
(0.000)\end{array}$ & $\begin{array}{l}-0.020 * * * \\
(0.000)\end{array}$ & $\begin{array}{c}-0.019 * * * \\
(0.000)\end{array}$ & $\begin{array}{c}-0.020 * * * \\
(0.000)\end{array}$ \\
\hline Tobin's Q & & $\begin{array}{c}0.008 * * * \\
(0.007)\end{array}$ & $\begin{array}{c}0.008 * * * \\
(0.007)\end{array}$ & $\begin{array}{c}0.008 * * * \\
(0.007)\end{array}$ & $\begin{array}{c}0.008 * * * \\
(0.008)\end{array}$ & $\begin{array}{c}0.008 * * * \\
(0.007)\end{array}$ \\
\hline Operating Return on Assets & & $\begin{array}{c}-0.292 * * * \\
(0.000)\end{array}$ & $\begin{array}{c}-0.290 * * * \\
(0.000)\end{array}$ & $\begin{array}{c}-0.291 * * * \\
(0.000)\end{array}$ & $\begin{array}{c}-0.289 * * * \\
(0.000)\end{array}$ & $\begin{array}{c}-0.292 * * * \\
(0.000)\end{array}$ \\
\hline R\&D Exp./Total Assets & & $\begin{array}{c}0.476 * * * \\
(0.000)\end{array}$ & $\begin{array}{c}0.473 * * * \\
(0.000)\end{array}$ & $\begin{array}{c}0.474 * * * \\
(0.000)\end{array}$ & $\begin{array}{c}0.478 * * * \\
(0.000)\end{array}$ & $\begin{array}{c}0.478 * * * \\
(0.000)\end{array}$ \\
\hline Advertising/Total Assets & & $\begin{array}{c}0.154 \\
(0.171)\end{array}$ & $\begin{array}{c}0.159 \\
(0.157)\end{array}$ & $\begin{array}{c}0.153 \\
(0.170)\end{array}$ & $\begin{array}{c}0.151 \\
(0.182)\end{array}$ & $\begin{array}{c}0.156 \\
(0.167)\end{array}$ \\
\hline CAPEXP/Total Assets & & $\begin{array}{c}0.289 * * * \\
(0.000)\end{array}$ & $\begin{array}{c}0.286^{* * * *} \\
(0.000)\end{array}$ & $\begin{array}{c}0.287 * * * \\
(0.000)\end{array}$ & $\begin{array}{c}0.287 * * * \\
(0.000)\end{array}$ & $\begin{array}{c}0.289 * * * \\
(0.000)\end{array}$ \\
\hline Leverage & & $\begin{array}{c}0.070^{* * * *} \\
(0.001)\end{array}$ & $\begin{array}{c}0.070^{* * * *} \\
(0.001)\end{array}$ & $\begin{array}{c}0.070^{* * *} \\
(0.001)\end{array}$ & $\begin{array}{c}0.073 * * * \\
(0.001)\end{array}$ & $\begin{array}{c}0.074 * * * \\
(0.001)\end{array}$ \\
\hline $\begin{array}{l}\text { Pay Directors Equity Based } \\
\text { Compensation }(0 / 1)\end{array}$ & & $\begin{array}{c}0.009 \\
(0.205)\end{array}$ & $\begin{array}{c}0.009 \\
(0.199)\end{array}$ & $\begin{array}{c}0.009 \\
(0.200)\end{array}$ & $\begin{array}{c}0.009 \\
(0.189)\end{array}$ & $\begin{array}{c}0.009 \\
(0.184)\end{array}$ \\
\hline Activist Institutional Holding (\%) & & $\begin{array}{l}-0.134 \\
(0.515)\end{array}$ & $\begin{array}{l}-0.131 \\
(0.525)\end{array}$ & $\begin{array}{l}-0.134 \\
(0.513)\end{array}$ & $\begin{array}{l}-0.127 \\
(0.536)\end{array}$ & $\begin{array}{l}-0.125 \\
(0.542)\end{array}$ \\
\hline CEO Cash Compensation & & $\begin{array}{c}-0.014 * * \\
(0.040)\end{array}$ & $\begin{array}{c}-0.013^{* *} \\
(0.047)\end{array}$ & $\begin{array}{c}-0.014 * * \\
(0.039)\end{array}$ & $\begin{array}{l}-0.013 * \\
(0.055)\end{array}$ & $\begin{array}{c}-0.014 * * \\
(0.045)\end{array}$ \\
\hline CEO Compensation Delta & & $\begin{array}{c}0.002 \\
(0.574)\end{array}$ & $\begin{array}{c}0.002 \\
(0.546)\end{array}$ & $\begin{array}{c}0.002 \\
(0.610)\end{array}$ & $\begin{array}{c}0.002 \\
(0.546)\end{array}$ & $\begin{array}{c}0.002 \\
(0.560)\end{array}$ \\
\hline CEO Compensation Vega & & $\begin{array}{l}-0.011 \\
(0.148)\end{array}$ & $\begin{array}{l}-0.012 \\
(0.132)\end{array}$ & $\begin{array}{l}-0.011 \\
(0.165)\end{array}$ & $\begin{array}{l}-0.011 \\
(0.155)\end{array}$ & $\begin{array}{l}-0.010 \\
(0.182)\end{array}$ \\
\hline Herfindhal Index & & $\begin{array}{c}0.357 * * * \\
(0.001)\end{array}$ & $\begin{array}{c}0.355^{* * *} \\
(0.001)\end{array}$ & $\begin{array}{c}0.355^{* * *} \\
(0.001)\end{array}$ & $\begin{array}{c}0.359 * * * \\
(0.001)\end{array}$ & $\begin{array}{c}0.352 * * * \\
(0.001)\end{array}$ \\
\hline
\end{tabular}


Table 13 Continued.

\begin{tabular}{lccccc}
\hline CEO Characteristics & & & & & \\
Ln(CEO Tenure+1) & 0.001 & 0.001 & 0.002 & -0.000 & -0.001 \\
CEO Age & $(0.881)$ & $(0.862)$ & $(0.678)$ & $(0.950)$ & $(0.853)$ \\
& $-0.055^{* *}$ & -0.029 & $-0.055^{* *}$ & $-0.047^{*}$ & $-0.043^{*}$ \\
MBA (0/1) & $(0.031)$ & $(0.297)$ & $(0.030)$ & $(0.062)$ & $(0.087)$ \\
& $-0.010^{*}$ & $-0.010^{*}$ & $-0.009^{*}$ & -0.009 & -0.009 \\
Founder (0/1) & $(0.079)$ & $(0.073)$ & $(0.099)$ & $(0.103)$ & $(0.117)$ \\
& $0.024^{* *}$ & $0.023^{* *}$ & $0.023^{* *}$ & $0.022^{* *}$ & $0.019^{*}$ \\
\# Functional Areas & $(0.033)$ & $(0.036)$ & $(0.035)$ & $(0.045)$ & $(0.065)$ \\
& 0.003 & 0.003 & 0.003 & 0.003 & 0.003 \\
Has Finance Background (0/1) & $(0.370)$ & $(0.349)$ & $(0.282)$ & $(0.265)$ & $(0.256)$ \\
& 0.001 & 0.001 & 0.001 & 0.001 & 0.001 \\
Constant & $(0.885)$ & $(0.909)$ & $(0.862)$ & $(0.852)$ & $(0.931)$ \\
& $0.615^{* * *}$ & $0.510^{* * *}$ & $0.622^{* * *}$ & $0.610^{* * *}$ & $0.602^{* * *}$ \\
Year Dummies & $(0.000)$ & $(0.000)$ & $(0.000)$ & $(0.000)$ & $(0.000)$ \\
Industry Dummies & Yes & Yes & Yes & Yes & Yes \\
Observations & Yes & Yes & Yes & Yes & Yes \\
Adjusted R-squared & 4693 & 4693 & 4693 & 4693 & 4693 \\
& 0.635 & 0.635 & 0.636 & 0.635 & 0.635 \\
Hansen's J-test (p-value) & & & & & \\
First-stage Instrumental Variables' Joint & 0.158 & 0.135 & 0.154 & 0.112 & 0.105 \\
Significance (F-stat) & & & & & \\
\hline
\end{tabular}


Table 14. CEO Employment History and Firm-specific Risk

This table presents IV/2SLS results for firm-specific risk for a sample of 4,693 firm years. The dependent variable in Panel A is firm-specific risk based on the market model. The dependent variable in Panel B is firm-specific risk based on the four-factor model. Refer to Table 1 and Appendix A for variable definitions. Instrumental variables are the unemployment rate for the year when the CEO started his first full-time job, non-business career dummy that equals one if the CEO had academic or government jobs, and the number of years the CEO has worked in his current firm's industry. Pre-turnover Specific Risk is the firm's specific risk in the year before the CEO turnover year. I report p-values of Hansen's J-test and first-stage $F$-stat at the bottom of the table. The values of the five CEO employment history proxies in the IV/2SLS estimations are predicted values. The predicted signs for the CEO employment history proxies are presented in parenthesis at the beginning of each row. I report $p$-values based on robust standard errors clustered at the firm level in parenthesis. $* * * * *$, and * indicate significance at the 1,5 , and $10 \%$ levels, respectively.

Panel A: Firm-Specific Risk (CAPM)

\begin{tabular}{|c|c|c|c|c|c|c|}
\hline \multirow{3}{*}{$\frac{\text { CEO Employment History Proxies }}{\text { \# Employers }}$} & \multirow{2}{*}{\multicolumn{2}{|c|}{$(1)$}} & \multirow[t]{2}{*}{$(2)$} & \multirow[t]{2}{*}{ (3) } & \multirow[t]{2}{*}{$(4)$} & \multirow[t]{2}{*}{ (5) } \\
\hline & & & & & & \\
\hline & $(+)$ & $\begin{array}{l}0.007^{* *} \\
(0.016)\end{array}$ & & & & \\
\hline \# Employer Changes per year & $(+)$ & & $\begin{array}{c}0.206^{* *} \\
(0.025)\end{array}$ & & & \\
\hline Employer Change Recency & $(+)$ & & & $\begin{array}{l}0.010^{* *} \\
(0.015)\end{array}$ & & \\
\hline Firm Experience Diversification & $(-)$ & & & & $\begin{array}{l}-0.029 * \\
(0.063)\end{array}$ & \\
\hline Industry Experience Diversification & $(-)$ & & & & & $\begin{array}{l}-0.022 \\
(0.146)\end{array}$ \\
\hline \multicolumn{7}{|l|}{ Firm Characteristics } \\
\hline Pre-turnover Firm-specific Risk & & $\begin{array}{c}0.197 * * * \\
(0.000)\end{array}$ & $\begin{array}{c}0.197 * * * \\
(0.000)\end{array}$ & $\begin{array}{c}0.198 * * * \\
(0.000)\end{array}$ & $\begin{array}{c}0.202 * * * \\
(0.000)\end{array}$ & $\begin{array}{c}0.205 * * * \\
(0.000)\end{array}$ \\
\hline $\ln$ (Total Sales) & & $\begin{array}{c}-0.019 * * * \\
(0.000)\end{array}$ & $\begin{array}{c}-0.019 * * * \\
(0.000)\end{array}$ & $\begin{array}{c}-0.019 * * * \\
(0.000)\end{array}$ & $\begin{array}{c}-0.019 * * * \\
(0.000)\end{array}$ & $\begin{array}{c}-0.020 * * * \\
(0.000)\end{array}$ \\
\hline Firm Age & & $\begin{array}{c}-0.017 * * * \\
(0.000)\end{array}$ & $\begin{array}{c}-0.016^{* * *} \\
(0.000)\end{array}$ & $\begin{array}{c}-0.017 * * * \\
(0.000)\end{array}$ & $\begin{array}{l}-0.016^{* * *} \\
(0.000)\end{array}$ & $\begin{array}{c}-0.017 * * * \\
(0.000)\end{array}$ \\
\hline Tobin's Q & & $\begin{array}{l}0.005^{*} \\
(0.068)\end{array}$ & $\begin{array}{l}0.005^{*} \\
(0.071)\end{array}$ & $\begin{array}{l}0.005^{*} \\
(0.069)\end{array}$ & $\begin{array}{l}0.004^{*} \\
(0.084)\end{array}$ & $\begin{array}{l}0.005^{*} \\
(0.073)\end{array}$ \\
\hline Operating Return on Assets & & $\begin{array}{c}-0.237 * * * \\
(0.000)\end{array}$ & $\begin{array}{l}-0.235^{* * *} \\
(0.000)\end{array}$ & $\begin{array}{c}-0.236^{* * *} \\
(0.000)\end{array}$ & $\begin{array}{l}-0.235^{* * *} \\
(0.000)\end{array}$ & $\begin{array}{c}-0.238 * * * \\
(0.000)\end{array}$ \\
\hline R\&D Exp./Total Assets & & $\begin{array}{l}0.414 * * * \\
(0.000)\end{array}$ & $\begin{array}{c}0.411 * * * \\
(0.000)\end{array}$ & $\begin{array}{c}0.410^{* * *} \\
(0.000)\end{array}$ & $\begin{array}{c}0.416 * * * \\
(0.000)\end{array}$ & $\begin{array}{c}0.417 * * * \\
(0.000)\end{array}$ \\
\hline Advertising/Total Assets & & $\begin{array}{l}0.177^{*} \\
(0.098)\end{array}$ & $\begin{array}{l}0.183^{*} \\
(0.087)\end{array}$ & $\begin{array}{l}0.176^{*} \\
(0.098)\end{array}$ & $\begin{array}{c}0.174 \\
(0.107)\end{array}$ & $\begin{array}{l}0.178^{*} \\
(0.094)\end{array}$ \\
\hline CAPEXP/Total Assets & & $\begin{array}{c}0.245^{* * *} \\
(0.000)\end{array}$ & $\begin{array}{c}0.243 * * * \\
(0.000)\end{array}$ & $\begin{array}{c}0.243 * * * \\
(0.000)\end{array}$ & $\begin{array}{c}0.245^{* * *} \\
(0.000)\end{array}$ & $\begin{array}{c}0.248^{* * * *} \\
(0.000)\end{array}$ \\
\hline Leverage & & $\begin{array}{c}0.075 * * * \\
(0.000)\end{array}$ & $\begin{array}{c}0.075 * * * \\
(0.000)\end{array}$ & $\begin{array}{c}0.075 * * * \\
(0.000)\end{array}$ & $\begin{array}{c}0.078 * * * \\
(0.000)\end{array}$ & $\begin{array}{c}0.080 * * * \\
(0.000)\end{array}$ \\
\hline $\begin{array}{l}\text { Pay Directors Equity Based } \\
\text { Compensation }(0 / 1)\end{array}$ & & $\begin{array}{l}0.008 \\
(0.225)\end{array}$ & $\begin{array}{c}0.008 \\
(0.216)\end{array}$ & $\begin{array}{c}0.008 \\
(0.220)\end{array}$ & $\begin{array}{c}0.008 \\
(0.203)\end{array}$ & $\begin{array}{c}0.008 \\
(0.197)\end{array}$ \\
\hline $\begin{array}{l}\text { Compensation (0/1) } \\
\text { Activist Institutional Holding (\%) }\end{array}$ & & $\begin{array}{c}(0.225) \\
-0.288 \\
(0.144)\end{array}$ & $\begin{array}{c}(0.216) \\
-0.284 \\
(0.148)\end{array}$ & $\begin{array}{c}(0 . \angle 20) \\
-0.287 \\
(0.140)\end{array}$ & $\begin{array}{c}(0.205) \\
-0.280 \\
(0.154)\end{array}$ & $\begin{array}{c}-0.278 \\
(0.156)\end{array}$ \\
\hline CEO Cash Compensation & & $\begin{array}{l}-0.008 \\
(0.159)\end{array}$ & $\begin{array}{l}-0.008 \\
(0.190)\end{array}$ & $\begin{array}{l}-0.008 \\
(0.152)\end{array}$ & $\begin{array}{l}-0.007 \\
(0.224)\end{array}$ & $\begin{array}{l}-0.008 \\
(0.174)\end{array}$ \\
\hline CEO Compensation Delta & & $\begin{array}{l}-0.000 \\
(0.991)\end{array}$ & $\begin{array}{c}0.000 \\
(0.960)\end{array}$ & $\begin{array}{l}-0.000 \\
(0.933)\end{array}$ & $\begin{array}{c}0.000 \\
(0.953)\end{array}$ & $\begin{array}{c}0.000 \\
(0.972)\end{array}$ \\
\hline CEO Compensation Vega & & $\begin{array}{l}-0.010 \\
(0.145)\end{array}$ & $\begin{array}{l}-0.011 \\
(0.119)\end{array}$ & $\begin{array}{l}-0.009 \\
(0.168)\end{array}$ & $\begin{array}{l}-0.010 \\
(0.147)\end{array}$ & $\begin{array}{l}-0.009 \\
(0.183)\end{array}$ \\
\hline Herfindhal Index & & $\begin{array}{c}0.310 * * * \\
(0.001)\end{array}$ & $\begin{array}{c}0.307 * * * \\
(0.002)\end{array}$ & $\begin{array}{c}0.307 * * * \\
(0.002)\end{array}$ & $\begin{array}{c}0.313 * * * \\
(0.002)\end{array}$ & $\begin{array}{c}0.304 * * * \\
(0.002)\end{array}$ \\
\hline
\end{tabular}


Table 14 Continued.

\begin{tabular}{|c|c|c|c|c|c|c|}
\hline \multicolumn{7}{|l|}{ CEO Characteristics } \\
\hline \multirow{2}{*}{\multicolumn{2}{|c|}{$\overline{\operatorname{Ln}(\mathrm{CEO} \text { Tenure }+1)}$}} & -0.002 & -0.001 & -0.000 & -0.003 & -0.004 \\
\hline & & $(0.714)$ & $(0.752)$ & $(0.987)$ & $(0.517)$ & $(0.407)$ \\
\hline \multirow{2}{*}{\multicolumn{2}{|c|}{ CEO Age }} & $-0.056 * *$ & -0.024 & $-0.056^{* *}$ & $-0.048 * *$ & $-0.043 *$ \\
\hline & & $(0.018)$ & $(0.334)$ & $(0.017)$ & $(0.041)$ & $(0.064)$ \\
\hline \multirow{2}{*}{\multicolumn{2}{|c|}{$\operatorname{MBA}(0 / 1)$}} & $-0.010^{*}$ & $-0.010^{*}$ & $-0.009 *$ & $-0.009 *$ & $-0.009 *$ \\
\hline & & $(0.060)$ & $(0.050)$ & $(0.082)$ & $(0.080)$ & $(0.092)$ \\
\hline \multirow{2}{*}{\multicolumn{2}{|c|}{ Founder $(0 / 1)$}} & $0.021 * *$ & $0.021 * *$ & $0.020 * *$ & $0.020 * *$ & $0.017 *$ \\
\hline & & $(0.032)$ & $(0.035)$ & $(0.037)$ & $(0.044)$ & $(0.076)$ \\
\hline \multirow{2}{*}{\multicolumn{2}{|c|}{ \# Functional Areas }} & 0.002 & 0.002 & 0.002 & 0.002 & 0.002 \\
\hline & & $(0.512)$ & $(0.487)$ & $(0.379)$ & $(0.359)$ & $(0.351)$ \\
\hline \multirow{2}{*}{\multicolumn{2}{|c|}{ Has Finance Background (0/1) }} & 0.001 & 0.001 & 0.002 & 0.002 & 0.001 \\
\hline & & $(0.829)$ & $(0.862)$ & $(0.799)$ & $(0.791)$ & $(0.908)$ \\
\hline \multirow{2}{*}{\multicolumn{2}{|c|}{ Constant }} & $0.612 * * *$ & $0.488 * * *$ & $0.620 * * *$ & $0.611 * * *$ & $0.602 * * *$ \\
\hline & & $(0.000)$ & $(0.000)$ & $(0.000)$ & $(0.000)$ & $(0.000)$ \\
\hline \multicolumn{2}{|l|}{ Year Dummies } & Yes & Yes & Yes & Yes & Yes \\
\hline \multicolumn{2}{|l|}{ Industry Dummies } & Yes & Yes & Yes & Yes & Yes \\
\hline \multicolumn{2}{|l|}{ Observations } & 4693 & 4693 & 4693 & 4693 & 4693 \\
\hline \multicolumn{2}{|l|}{ Adjusted R-squared } & 0.655 & 0.655 & 0.656 & 0.654 & 0.655 \\
\hline \multirow{3}{*}{\multicolumn{2}{|c|}{$\begin{array}{l}\text { Hansen's J-test (p-value) } \\
\text { First-stage Instrumental Variables' Joint } \\
\text { Significance (F-stat) }\end{array}$}} & 0.136 & 0.111 & 0.132 & 0.115 & 0.107 \\
\hline & & & & & & \\
\hline & & 62.49 & 57.68 & 69.78 & 90.23 & 113.54 \\
\hline \multicolumn{7}{|c|}{ Panel B: Firm-specific Risk (Four-Factor Model) } \\
\hline & & $(1)$ & (2) & $(3)$ & (4) & $(5)$ \\
\hline \multicolumn{7}{|l|}{ CEO Employment History Proxies } \\
\hline \# Employers & $(+)$ & $\begin{array}{c}0.007 * * * \\
(0.010)\end{array}$ & & & & \\
\hline \# Employer Changes per year & $(+)$ & & $\begin{array}{c}0.226 * * \\
(0.011)\end{array}$ & & & \\
\hline Employer Change Recency & $(+)$ & & & $\begin{array}{c}0.011 * * * \\
(0.007)\end{array}$ & & \\
\hline Firm Experience Diversification & $(-)$ & & & & $\begin{array}{c}-0.033 * * \\
(0.031)\end{array}$ & \\
\hline Industry Experience Diversification & $(-)$ & & & & & $\begin{array}{l}-0.026^{*} \\
(0.081)\end{array}$ \\
\hline \multicolumn{7}{|l|}{ Firm Characteristics } \\
\hline \multicolumn{2}{|l|}{ Pre-turnover Firm-specific Risk (4- } & $\begin{array}{c}0.158 * * * \\
(0.000)\end{array}$ & $\begin{array}{c}0.193 * * * \\
(0.000)\end{array}$ & $\begin{array}{c}0.194 * * * \\
(0.000)\end{array}$ & $\begin{array}{c}0.199 * * * \\
(0.000)\end{array}$ & $\begin{array}{c}0.202 * * * \\
(0.000)\end{array}$ \\
\hline \multicolumn{2}{|l|}{$\ln ($ Total Sales $)$} & $\begin{array}{c}-0.018 * * * \\
(0.000)\end{array}$ & $\begin{array}{c}-0.018 * * * \\
(0.000)\end{array}$ & $\begin{array}{c}-0.019 * * * \\
(0.000)\end{array}$ & $\begin{array}{c}-0.019 * * * \\
(0.000)\end{array}$ & $\begin{array}{c}-0.020 * * * \\
(0.000)\end{array}$ \\
\hline \multicolumn{2}{|l|}{ Firm Age } & $\begin{array}{c}-0.015^{* * *} \\
(0.000)\end{array}$ & $\begin{array}{c}-0.016 * * * \\
(0.000)\end{array}$ & $\begin{array}{c}-0.016 * * * \\
(0.000)\end{array}$ & $\begin{array}{c}-0.015^{* * *} \\
(0.000)\end{array}$ & $\begin{array}{c}-0.016 * * * \\
(0.000)\end{array}$ \\
\hline \multicolumn{2}{|l|}{ Tobin's Q } & 0.004 & 0.004 & 0.004 & 0.004 & 0.004 \\
\hline & & $(0.113)$ & $(0.123)$ & $(0.121)$ & $(0.146)$ & $(0.126)$ \\
\hline \multicolumn{2}{|l|}{ Operating Return on Assets } & $\begin{array}{c}-0.218 * * * \\
(0.000)\end{array}$ & $\begin{array}{c}-0.215 * * * \\
(0.000)\end{array}$ & $\begin{array}{c}-0.216 * * * \\
(0.000)\end{array}$ & $\begin{array}{c}-0.214 * * * \\
(0.000)\end{array}$ & $\begin{array}{c}-0.218 * * * \\
(0.000)\end{array}$ \\
\hline R\&D Exp./Total Assets & & $\begin{array}{c}0.375 * * * \\
(0.000)\end{array}$ & $0.383 * * *$ & $\begin{array}{c}0.383 * * * \\
(0000)\end{array}$ & $0.389 * * *$ & $0.390 * * *$ \\
\hline Advertising/Total Assets & & $\begin{array}{c}0.169 \\
(0.106) \\
\end{array}$ & $\begin{array}{l}0.190 * \\
(0.072)\end{array}$ & $\begin{array}{l}0.182^{*} \\
(0.081)\end{array}$ & $\begin{array}{l}0.179 * \\
(0.092)\end{array}$ & $\begin{array}{l}0.183 * \\
(0.079) \\
\end{array}$ \\
\hline
\end{tabular}


Table 14 Continued.

\begin{tabular}{|c|c|c|c|c|c|}
\hline \multicolumn{6}{|l|}{ Firm Characteristics (Continued) } \\
\hline CAPEXP/Total Assets & $\begin{array}{c}0.218^{* * *} \\
(0.000)\end{array}$ & $\begin{array}{c}0.225^{* * *} \\
(0.000)\end{array}$ & $\begin{array}{c}0.225^{* * *} * \\
(0.000)\end{array}$ & $\begin{array}{c}0.227 * * * \\
(0.000)\end{array}$ & $\begin{array}{c}0.231 * * * \\
(0.000)\end{array}$ \\
\hline Leverage & $\begin{array}{c}0.071^{* * * *} \\
(0.000)\end{array}$ & $\begin{array}{c}0.075^{* * * *} \\
(0.000)\end{array}$ & $\begin{array}{c}0.075^{* * * *} \\
(0.000)\end{array}$ & $\begin{array}{c}0.078 * * * \\
(0.000)\end{array}$ & $\begin{array}{c}0.079 * * * \\
(0.000)\end{array}$ \\
\hline Pay Directors Equity Based & 0.008 & 0.008 & 0.008 & 0.008 & 0.008 \\
\hline Compensation $(0 / 1)$ & $(0.157)$ & $(0.194)$ & $(0.197)$ & $(0.182)$ & $(0.177)$ \\
\hline Activist Institutional Holding (\%) & $\begin{array}{l}-0.298 \\
(0.119)\end{array}$ & $\begin{array}{l}-0.295 \\
(0.125)\end{array}$ & $\begin{array}{l}-0.299 \\
(0.118)\end{array}$ & $\begin{array}{l}-0.291 \\
(0.130)\end{array}$ & $\begin{array}{l}-0.289 \\
(0.132)\end{array}$ \\
\hline CEO Cash Compensation & $\begin{array}{l}-0.005 \\
(0.353)\end{array}$ & $\begin{array}{l}-0.006 \\
(0.285)\end{array}$ & $\begin{array}{l}-0.007 \\
(0.228)\end{array}$ & $\begin{array}{l}-0.005 \\
(0.337)\end{array}$ & $\begin{array}{l}-0.006 \\
(0.260)\end{array}$ \\
\hline CEO Compensation Delta & $\begin{array}{l}-0.000 \\
(0.875)\end{array}$ & $\begin{array}{l}-0.000 \\
(0.936)\end{array}$ & $\begin{array}{l}-0.001 \\
(0.818)\end{array}$ & $\begin{array}{l}-0.000 \\
(0.944)\end{array}$ & $\begin{array}{l}-0.000 \\
(0.924)\end{array}$ \\
\hline CEO Compensation Vega & $\begin{array}{l}-0.009 \\
(0.178)\end{array}$ & $\begin{array}{l}-0.010 \\
(0.144)\end{array}$ & $\begin{array}{l}-0.008 \\
(0.214)\end{array}$ & $\begin{array}{l}-0.009 \\
(0.181)\end{array}$ & $\begin{array}{l}-0.008 \\
(0.229)\end{array}$ \\
\hline Herfindhal Index & $\begin{array}{c}0.292 * * * \\
(0.002)\end{array}$ & $\begin{array}{c}0.289 * * * \\
(0.003)\end{array}$ & $\begin{array}{c}0.289 * * * \\
(0.003)\end{array}$ & $\begin{array}{c}0.296^{* * *} \\
(0.002)\end{array}$ & $\begin{array}{c}0.286^{* * *} \\
(0.003)\end{array}$ \\
\hline \multicolumn{6}{|l|}{ CEO Characteristics } \\
\hline$\overline{\mathrm{Ln}(\mathrm{CEO} \text { Tenure+1) }}$ & $\begin{array}{l}-0.004 \\
(0.300)\end{array}$ & $\begin{array}{l}-0.002 \\
(0.670)\end{array}$ & $\begin{array}{l}-0.000 \\
(0.915)\end{array}$ & $\begin{array}{l}-0.003 \\
(0.421)\end{array}$ & $\begin{array}{l}-0.004 \\
(0.311)\end{array}$ \\
\hline CEO Age & $\begin{array}{c}-0.060^{* * *} \\
(0.008)\end{array}$ & $\begin{array}{l}-0.022 \\
(0.362)\end{array}$ & $\begin{array}{c}-0.056^{* *} \\
(0.012)\end{array}$ & $\begin{array}{c}-0.048^{* *} \\
(0.033)\end{array}$ & $\begin{array}{c}-0.043^{*} \\
(0.055)\end{array}$ \\
\hline $\operatorname{MBA}(0 / 1)$ & $\begin{array}{c}-0.010^{* *} \\
(0.035)\end{array}$ & $\begin{array}{c}-0.010^{* *} \\
(0.038)\end{array}$ & $\begin{array}{c}-0.009^{*} \\
(0.069)\end{array}$ & $\begin{array}{c}-0.009^{*} \\
(0.065)\end{array}$ & $\begin{array}{c}-0.009^{*} \\
(0.075)\end{array}$ \\
\hline Founder $(0 / 1)$ & $\begin{array}{c}0.019 * * \\
(0.038)\end{array}$ & $\begin{array}{c}0.021^{* *} \\
(0.032)\end{array}$ & $\begin{array}{c}0.020^{* *} \\
(0.036)\end{array}$ & $\begin{array}{c}0.020^{* *} \\
(0.040)\end{array}$ & $\begin{array}{l}0.016^{*} \\
(0.076)\end{array}$ \\
\hline \# Functional Areas & $\begin{array}{c}0.001 \\
(0.601)\end{array}$ & $\begin{array}{c}0.001 \\
(0.667)\end{array}$ & $\begin{array}{c}0.002 \\
(0.523)\end{array}$ & $\begin{array}{c}0.002 \\
(0.502)\end{array}$ & $\begin{array}{c}0.002 \\
(0.496)\end{array}$ \\
\hline Has Finance Background (0/1) & $\begin{array}{c}0.001 \\
(0.877)\end{array}$ & $\begin{array}{c}0.001 \\
(0.896)\end{array}$ & $\begin{array}{c}0.001 \\
(0.823)\end{array}$ & $\begin{array}{c}0.001 \\
(0.818)\end{array}$ & $\begin{array}{c}0.000 \\
(0.960)\end{array}$ \\
\hline Constant & $\begin{array}{c}0.641^{* * *} \\
(0.000)\end{array}$ & $\begin{array}{c}0.472 * * * \\
(0.000)\end{array}$ & $\begin{array}{c}0.616 * * * \\
(0.000)\end{array}$ & $\begin{array}{c}0.607 * * * \\
(0.000)\end{array}$ & $\begin{array}{c}0.598 * * * \\
(0.000)\end{array}$ \\
\hline Year Dummies & Yes & Yes & Yes & Yes & Yes \\
\hline Industry Dummies & Yes & Yes & Yes & Yes & Yes \\
\hline Observations & 4693 & 4693 & 4693 & 4693 & 4693 \\
\hline Adjusted R-squared & 0.654 & 0.652 & 0.654 & 0.652 & 0.653 \\
\hline $\begin{array}{l}\text { Hansen's J-test (p-value) } \\
\text { First-stage Instrumental Variables' Joint }\end{array}$ & 0.166 & 0.134 & 0.161 & 0.125 & 0.117 \\
\hline Significance (F-stat) & 62.04 & 57.79 & 69.96 & 90.34 & 113.58 \\
\hline
\end{tabular}


Table 15. CEO Employment History and Market Risk

This table presents IV/2SLS results for a firm's market risk for a sample of 4,693 firm years. The dependent variable in Panel A is the market beta from the CAPM model, in Panel B is the unlevered market beta from the CAPM model, in Panel C is the size beta from the 4-factor model, in Panel D is the book-to-market beta from the 4-factor model, and in Panel E is the momentum beta from the 4-factor model. Panel F and G present the analysis for segments. The dependent variable in Panel $\mathrm{F}$ is the Herfindhal concentration of segment sales, operating income, capital expenditures and assets. Panel $\mathrm{F}$ presents the multinomial regression results for the likelihoods of adding or reducing a segment or a segment with a new SIC code. The base category is when there is no change in the number of segment. Refer to Table 1 and Appendix A for variable definitions. Instrumental variables are the unemployment rate for the year when the CEO started his first full-time job, non-business career dummy that equals one if the CEO had academic or government jobs, and the number of years the CEO has worked in his current firm's industry. Preturnover Market Risk is the firm's market risk in the year before the CEO turnover year. I report p-values of Hansen's J-test and first-stage $F$-stat at the bottom of the table. The values of the five CEO employment history proxies in the IV/2SLS estimations are predicted values. The predicted signs for the CEO employment history proxies are presented in parenthesis at the beginning of each row. I report $p$-values based on robust standard errors clustered at the firm level in parenthesis. ${ }^{* *},{ }^{* *}$, and * indicate significance at the 1,5 , and $10 \%$ levels, respectively.

Panel A: Market Beta from the CAPM Model

\begin{tabular}{|c|c|c|c|c|c|c|}
\hline \multirow[b]{2}{*}{ CEO Employment History Proxies } & & (1) & (2) & (3) & (4) & $(5)$ \\
\hline & & & & & & \\
\hline \# Employers & $(+)$ & $\begin{array}{c}0.001 \\
(0.924)\end{array}$ & & & & \\
\hline \# Employer Changes per year & $(+)$ & & $\begin{array}{l}-0.063 \\
(0.878)\end{array}$ & & & \\
\hline Employer Change Recency & $(+)$ & & & $\begin{array}{l}-0.005 \\
(0.707)\end{array}$ & & \\
\hline Firm Experience Diversification & $(-)$ & & & & $\begin{array}{c}0.033 \\
(0.645)\end{array}$ & \\
\hline Industry Experience & $(-)$ & & & & & $\begin{array}{c}0.047 \\
(0.511)\end{array}$ \\
\hline \multicolumn{7}{|l|}{ Firm Characteristics } \\
\hline$\overline{\text { Pre-turnover Market Risk }}$ & & $\begin{array}{c}0.263 * * * \\
(0.000)\end{array}$ & $\begin{array}{c}0.263 * * * \\
(0.000)\end{array}$ & $\begin{array}{c}0.263 * * * \\
(0.000)\end{array}$ & $\begin{array}{c}0.263 * * * \\
(0.000)\end{array}$ & $\begin{array}{c}0.263 * * * \\
(0.000)\end{array}$ \\
\hline $\ln$ (Total Sales) & & $\begin{array}{c}-0.023 * * \\
(0.018)\end{array}$ & $\begin{array}{c}-0.023 * * \\
(0.020)\end{array}$ & $\begin{array}{c}-0.024 * * \\
(0.015)\end{array}$ & $\begin{array}{c}-0.024 * * \\
(0.013)\end{array}$ & $\begin{array}{c}-0.024 * * * \\
(0.010)\end{array}$ \\
\hline Firm Age & & $\begin{array}{c}-0.053 * * * \\
(0.004)\end{array}$ & $\begin{array}{c}-0.053 * * * \\
(0.005)\end{array}$ & $\begin{array}{c}-0.054 * * * \\
(0.004)\end{array}$ & $\begin{array}{c}-0.055^{* * *} \\
(0.004)\end{array}$ & $\begin{array}{c}-0.055^{* * *} \\
(0.003)\end{array}$ \\
\hline Tobin's Q & & $\begin{array}{l}0.031^{* *} \\
(0.012)\end{array}$ & $\begin{array}{c}0.031^{* *} \\
(0.012)\end{array}$ & $\begin{array}{l}0.030^{* *} \\
(0.012)\end{array}$ & $\begin{array}{l}0.030^{* *} \\
(0.012)\end{array}$ & $\begin{array}{l}0.030^{* *} \\
(0.013)\end{array}$ \\
\hline Operating Return on Assets & & $\begin{array}{c}-0.586^{* * *} * \\
(0.000)\end{array}$ & $\begin{array}{c}-0.586^{* * *} \\
(0.000)\end{array}$ & $\begin{array}{c}-0.586^{* * *} \\
(0.000)\end{array}$ & $\begin{array}{c}-0.586^{* * *} \\
(0.000)\end{array}$ & $\begin{array}{c}-0.580 * * * \\
(0.000)\end{array}$ \\
\hline R\&D Exp./Total Assets & & $\begin{array}{l}0.972 * * * \\
(0.002)\end{array}$ & $\begin{array}{c}0.972 * * * \\
(0.002)\end{array}$ & $\begin{array}{c}0.970 * * * \\
(0.002)\end{array}$ & $\begin{array}{c}0.971 * * * \\
(0.002)\end{array}$ & $\begin{array}{c}0.972 * * * \\
(0.002)\end{array}$ \\
\hline Advertising/Total Assets & & $\begin{array}{c}-1.403 * * * \\
(0.000)\end{array}$ & $\begin{array}{c}-1.405 * * * \\
(0.000)\end{array}$ & $\begin{array}{c}-1.393 * * * \\
(0.000)\end{array}$ & $\begin{array}{c}-1.389 * * * \\
(0.000)\end{array}$ & $\begin{array}{c}-1.387 * * * \\
(0.000)\end{array}$ \\
\hline CAPEXP/Total Assets & & $\begin{array}{c}0.289 \\
(0.159)\end{array}$ & $\begin{array}{c}0.289 \\
(0.159)\end{array}$ & $\begin{array}{c}0.287 \\
(0.160)\end{array}$ & $\begin{array}{c}0.286 \\
(0.162)\end{array}$ & $\begin{array}{c}0.266 \\
(0.206)\end{array}$ \\
\hline Leverage & & $\begin{array}{c}0.006 \\
(0.939)\end{array}$ & $\begin{array}{c}0.005 \\
(0.942)\end{array}$ & $\begin{array}{c}0.008 \\
(0.918)\end{array}$ & $\begin{array}{c}0.009 \\
(0.905)\end{array}$ & $\begin{array}{c}0.011 \\
(0.885)\end{array}$ \\
\hline $\begin{array}{l}\text { Pay Directors Equity Based } \\
\text { Compensation }(0 / 1)\end{array}$ & & $\begin{array}{l}-0.001 \\
(0.980)\end{array}$ & $\begin{array}{l}-0.001 \\
(0.978)\end{array}$ & $\begin{array}{l}-0.000 \\
(0.990)\end{array}$ & $\begin{array}{l}-0.000 \\
(0.999)\end{array}$ & $\begin{array}{c}0.000 \\
(0.985)\end{array}$ \\
\hline Activist Institutional Holding (\%) & & $\begin{array}{l}1.668^{* *} \\
(0.024)\end{array}$ & $\begin{array}{l}1.669^{* *} \\
(0.024)\end{array}$ & $\begin{array}{l}1.669^{* *} \\
(0.024)\end{array}$ & $\begin{array}{l}1.671^{* *} \\
(0.023)\end{array}$ & $\begin{array}{l}1.674 * * \\
(0.023)\end{array}$ \\
\hline CEO Cash Compensation & & $\begin{array}{c}-0.109 * * * \\
(0.000)\end{array}$ & $\begin{array}{c}-0.109 * * * \\
(0.000)\end{array}$ & $\begin{array}{c}-0.109 * * * \\
(0.000)\end{array}$ & $\begin{array}{c}-0.109 * * * \\
(0.000)\end{array}$ & $\begin{array}{c}-0.109 * * * \\
(0.000)\end{array}$ \\
\hline CEO Compensation Delta & & $\begin{array}{l}0.037^{*} \\
(0.057)\end{array}$ & $\begin{array}{l}0.037^{*} \\
(0.057)\end{array}$ & $\begin{array}{l}0.037^{*} \\
(0.057)\end{array}$ & $\begin{array}{l}0.037^{*} \\
(0.058)\end{array}$ & $\begin{array}{c}0.037^{*} \\
(0.058)\end{array}$ \\
\hline
\end{tabular}


Table 15 Continued.

\begin{tabular}{lccccc}
\hline CEO Characteristics & & & & \\
CEO Compensation Vega & $-0.142^{* * *}$ & $-0.142^{* * *}$ & $-0.141^{* * *}$ & $-0.141^{* * *}$ & $-0.140^{* * *}$ \\
Herfindhal Index & $(0.000)$ & $(0.000)$ & $(0.000)$ & $(0.000)$ & $(0.000)$ \\
& $-0.284^{* *}$ & $-0.284^{* *}$ & $-0.288^{* *}$ & $-0.291^{* *}$ & $-0.286^{* *}$ \\
Ln(CEO Tenure+1) & $(0.031)$ & $(0.031)$ & $(0.028)$ & $(0.027)$ & $(0.028)$ \\
& 0.008 & 0.008 & 0.007 & 0.007 & 0.007 \\
CEO Age & $(0.646)$ & $(0.640)$ & $(0.677)$ & $(0.684)$ & $(0.694)$ \\
& -0.003 & 0.004 & 0.003 & 0.005 & 0.009 \\
MBA (0/1) & $(0.980)$ & $(0.973)$ & $(0.974)$ & $(0.958)$ & $(0.930)$ \\
& -0.014 & -0.014 & -0.013 & -0.013 & -0.012 \\
Founder (0/1) & $(0.544)$ & $(0.543)$ & $(0.566)$ & $(0.571)$ & $(0.601)$ \\
& 0.008 & 0.008 & 0.006 & 0.004 & 0.002 \\
\# Functional Areas & $(0.835)$ & $(0.829)$ & $(0.882)$ & $(0.924)$ & $(0.948)$ \\
& 0.019 & 0.019 & 0.019 & 0.019 & 0.019 \\
Has Finance Background (0/1) & $(0.120)$ & $(0.119)$ & $(0.113)$ & $(0.112)$ & $(0.105)$ \\
& -0.034 & -0.034 & -0.034 & -0.033 & -0.032 \\
Constant & $(0.164)$ & $(0.163)$ & $(0.169)$ & $(0.170)$ & $(0.188)$ \\
& $1.264^{* * *}$ & $1.237 * * *$ & $1.252^{* * *}$ & $1.241 * * *$ & $1.220^{* * *}$ \\
Year Dummies & $(0.002)$ & $(0.006)$ & $(0.003)$ & $(0.003)$ & $(0.004)$ \\
Observations & Yes & Yes & Yes & Yes & Yes \\
Adjusted R-squared & 4689 & 4689 & 4689 & 4689 & 4689 \\
& 0.358 & 0.358 & 0.358 & 0.358 & 0.358 \\
Hansen's J-test (p-value) & & & & & \\
First-stage Instrumental Variables' Joint & 0.632 & 0.632 & 0.635 & 0.644 & 0.666 \\
Significance (F-stat) & & & & & \\
& 56.41 & 53.02 & 53.07 & 86.85 & 117.140 \\
\hline
\end{tabular}

Panel B: Market Beta from the CAPM Model (Unlevered)

\begin{tabular}{|c|c|c|c|c|c|c|}
\hline \multirow[b]{2}{*}{$\underline{\text { CEO Employment History Proxies }}$} & & (1) & (2) & (3) & (4) & $(5)$ \\
\hline & & & & & & \\
\hline \# Employers & $(+)$ & $\begin{array}{c}-0.026^{*} \\
(0.057)\end{array}$ & & & & \\
\hline \# Employer Changes per year & $(+)$ & & $\begin{array}{l}-0.802 * \\
(0.071)\end{array}$ & & & \\
\hline Employer Change Recency & $(+)$ & & & $\begin{array}{c}-0.043 * * \\
(0.048)\end{array}$ & & \\
\hline Firm Experience Diversification & $(-)$ & & & & $\begin{array}{c}0.152 * * \\
(0.045)\end{array}$ & \\
\hline Industry Experience & $(-)$ & & & & & $\begin{array}{c}0.111^{* *} \\
(0.043)\end{array}$ \\
\hline \multicolumn{7}{|l|}{ Firm Characteristics } \\
\hline Pre-turnover Market Risk & & $\begin{array}{c}0.167 * * * \\
(0.000)\end{array}$ & $\begin{array}{c}0.166^{* * *} \\
(0.000)\end{array}$ & $\begin{array}{c}0.167 * * * \\
(0.000)\end{array}$ & $\begin{array}{c}0.162 * * * \\
(0.000)\end{array}$ & $\begin{array}{c}0.163 * * * \\
(0.000)\end{array}$ \\
\hline $\ln$ (Total Sales) & & $\begin{array}{c}-0.053 * * * \\
(0.000)\end{array}$ & $\begin{array}{c}-0.053^{* * *} \\
(0.000)\end{array}$ & $\begin{array}{c}-0.052^{* * *} \\
(0.000)\end{array}$ & $\begin{array}{c}-0.053^{* * *} * \\
(0.000)\end{array}$ & $\begin{array}{c}-0.048 * * * \\
(0.000)\end{array}$ \\
\hline Firm Age & & $\begin{array}{c}-0.049 * * * \\
(0.003)\end{array}$ & $\begin{array}{c}-0.051^{* * *} \\
(0.003)\end{array}$ & $\begin{array}{c}-0.049 * * * \\
(0.003)\end{array}$ & $\begin{array}{c}-0.054 * * * \\
(0.002)\end{array}$ & $\begin{array}{c}-0.047 * * * \\
(0.003)\end{array}$ \\
\hline Tobin's Q & & $\begin{array}{c}0.077 * * * \\
(0.000)\end{array}$ & $\begin{array}{c}0.077 * * * \\
(0.000)\end{array}$ & $\begin{array}{c}0.077 * * * \\
(0.000)\end{array}$ & $\begin{array}{c}0.078 * * * \\
(0.000)\end{array}$ & $\begin{array}{c}0.077 * * * \\
(0.000)\end{array}$ \\
\hline Operating Return on Assets & & $\begin{array}{c}0.157 \\
(0.250)\end{array}$ & $\begin{array}{c}0.150 \\
(0.271)\end{array}$ & $\begin{array}{c}0.156 \\
(0.259)\end{array}$ & $\begin{array}{c}0.151 \\
(0.275)\end{array}$ & $\begin{array}{c}0.170 \\
(0.215)\end{array}$ \\
\hline
\end{tabular}


Table 15 Continued

\begin{tabular}{|c|c|c|c|c|c|}
\hline \multicolumn{6}{|l|}{ Firm Characteristics (Continued) } \\
\hline \\
\hline Advertising/Total Assets & \multicolumn{5}{|l|}{$\begin{array}{c}1.597 * * * \\
(0.000) \\
0.026 \\
(0.944)\end{array}$} \\
\hline CAPEXP & $\begin{array}{c}0.247 \\
(0217)\end{array}$ & $\begin{array}{c}0.256 \\
(0.203)\end{array}$ & $\begin{array}{c}0.252 \\
(0211)\end{array}$ & $\begin{array}{c}0.233 \\
(0245)\end{array}$ & $\begin{array}{c}0.219 \\
(0.274)\end{array}$ \\
\hline Leverage & $\begin{array}{c}0.003 \\
(0.963)\end{array}$ & $\begin{array}{c}0.004 \\
(0.944)\end{array}$ & $\begin{array}{c}0.010 \\
(0.876)\end{array}$ & $\begin{array}{l}-0.004 \\
(0.943)\end{array}$ & $\begin{array}{l}-0.019 \\
(0.735)\end{array}$ \\
\hline Pay Directors Equity Based & -0.009 & -0.010 & -0.009 & -0.009 & -0.011 \\
\hline Compensation $(0 / 1)$ & $(0.676)$ & $(0.654)$ & $(0.686)$ & $(0.674)$ & $(0.626)$ \\
\hline Activist Institutional Holding (\%) & $\begin{array}{c}1.301 * * \\
(0.034)\end{array}$ & $\begin{array}{c}1.288 * * \\
(0.034)\end{array}$ & $\begin{array}{l}1.308 * * \\
(0.032)\end{array}$ & $\begin{array}{l}1.283^{* *} \\
(0.036)\end{array}$ & $\begin{array}{l}1.269 * * \\
(0.038)\end{array}$ \\
\hline CEO Cash Compensation & $\begin{array}{c}-0.105 * * * \\
(0.000)\end{array}$ & $\begin{array}{c}-0.107 * * * \\
(0.000)\end{array}$ & $\begin{array}{c}-0.104 * * * \\
(0.000)\end{array}$ & $\begin{array}{c}-0.110 * * * \\
(0.000)\end{array}$ & $\begin{array}{c}-0.106^{* * *} * \\
(0.000)\end{array}$ \\
\hline CEO Compensation Delta & $\begin{array}{c}0.022 \\
(0.173)\end{array}$ & $\begin{array}{c}0.021 \\
(0.194)\end{array}$ & $\begin{array}{c}0.023 \\
(0.150)\end{array}$ & $\begin{array}{c}0.021 \\
(0.201)\end{array}$ & $\begin{array}{c}0.021 \\
(0.181)\end{array}$ \\
\hline CEO Compensation Vega & $\begin{array}{l}-0.043 \\
(0.148)\end{array}$ & $\begin{array}{l}-0.039 \\
(0.196)\end{array}$ & $\begin{array}{l}-0.045 \\
(0.128)\end{array}$ & $\begin{array}{l}-0.039 \\
(0.195)\end{array}$ & $\begin{array}{l}-0.044 \\
(0.126)\end{array}$ \\
\hline Herfindhal Index & $\begin{array}{c}0.143 \\
(0.710)\end{array}$ & $\begin{array}{c}0.155 \\
(0.687)\end{array}$ & $\begin{array}{c}0.153 \\
(0.689)\end{array}$ & $\begin{array}{c}0.119 \\
(0.754)\end{array}$ & $\begin{array}{c}0.165 \\
(0.664)\end{array}$ \\
\hline \multicolumn{6}{|l|}{ CEO Characteristics } \\
\hline $\operatorname{Ln}($ CEO Tenure +1$)$ & $\begin{array}{l}-0.013 \\
(0.342)\end{array}$ & $\begin{array}{l}-0.015 \\
(0.314)\end{array}$ & $\begin{array}{l}-0.021 \\
(0.178)\end{array}$ & $\begin{array}{l}-0.011 \\
(0.415)\end{array}$ & $\begin{array}{l}-0.007 \\
(0.598)\end{array}$ \\
\hline CEO Age & $\begin{array}{c}0.123 \\
(0.170)\end{array}$ & $\begin{array}{c}0.001 \\
(0.993)\end{array}$ & $\begin{array}{c}0.125 \\
(0.164)\end{array}$ & $\begin{array}{c}0.105 \\
(0.223)\end{array}$ & $\begin{array}{c}0.083 \\
(0.318)\end{array}$ \\
\hline $\operatorname{MBA}(0 / 1)$ & $\begin{array}{l}-0.012 \\
(0.513)\end{array}$ & $\begin{array}{l}-0.010 \\
(0.598)\end{array}$ & $\begin{array}{l}-0.015 \\
(0.413)\end{array}$ & $\begin{array}{l}-0.012 \\
(0.503)\end{array}$ & $\begin{array}{l}-0.014 \\
(0.423)\end{array}$ \\
\hline Founder $(0 / 1)$ & $\begin{array}{c}0.023 \\
(0.487)\end{array}$ & $\begin{array}{c}0.023 \\
(0.490)\end{array}$ & $\begin{array}{c}0.025 \\
(0.454)\end{array}$ & $\begin{array}{c}0.019 \\
(0.581)\end{array}$ & $\begin{array}{c}0.038 \\
(0.205)\end{array}$ \\
\hline \# Functional Areas & $\begin{array}{c}0.009 \\
(0.368)\end{array}$ & $\begin{array}{c}0.009 \\
(0.385)\end{array}$ & $\begin{array}{c}0.007 \\
(0.481)\end{array}$ & $\begin{array}{c}0.007 \\
(0.474)\end{array}$ & $\begin{array}{c}0.007 \\
(0.482)\end{array}$ \\
\hline Has Finance Background $(0 / 1)$ & $\begin{array}{l}-0.012 \\
(0.536)\end{array}$ & $\begin{array}{l}-0.011 \\
(0.571)\end{array}$ & $\begin{array}{l}-0.013 \\
(0.507)\end{array}$ & $\begin{array}{l}-0.013 \\
(0.518)\end{array}$ & $\begin{array}{l}-0.009 \\
(0.665)\end{array}$ \\
\hline Constant & $\begin{array}{c}0.557 \\
(0.120)\end{array}$ & $\begin{array}{l}1.045^{* *} \\
(0.012)\end{array}$ & $\begin{array}{c}0.536 \\
(0.139)\end{array}$ & $\begin{array}{c}0.493 \\
(0.170)\end{array}$ & $\begin{array}{c}0.538 \\
(0.126)\end{array}$ \\
\hline Year Dummies & Yes & Yes & Yes & Yes & Yes \\
\hline Industry Dummies & Yes & Yes & Yes & Yes & Yes \\
\hline Observations & 4693 & 4693 & 4693 & 4693 & 4693 \\
\hline Adjusted R-squared & 0.503 & 0.503 & 0.503 & 0.503 & 0.508 \\
\hline $\begin{array}{l}\text { Hansen's J-test (p-value) } \\
\text { First-stage Instrumental Variables' Joint }\end{array}$ & 0.729 & 0.614 & 0.821 & 0.852 & 0.834 \\
\hline Significance (F-stat) & 55.35 & 57.21 & 59.62 & 92.43 & 274.54 \\
\hline
\end{tabular}


Table 15 Continued.

Panel C: The Size Beta from the Four-Factor Model

\begin{tabular}{|c|c|c|c|c|c|c|}
\hline & & $(1)$ & $(2)$ & (3) & (4) & $(5)$ \\
\hline \multicolumn{7}{|c|}{$\underline{\text { CEO Employment History Variables }}$} \\
\hline \# Employers & $(+)$ & $\begin{array}{l}-0.017 \\
(0.287)\end{array}$ & & & & \\
\hline \# Employer Changes per year & $(+)$ & & $\begin{array}{l}-0.508 \\
(0.333)\end{array}$ & & & \\
\hline Employer Change Recency & $(+)$ & & & $\begin{array}{c}-0.028 \\
(0.276)\end{array}$ & & \\
\hline Firm Experience Diversification & $(-)$ & & & & $\begin{array}{c}0.098 \\
(0.281)\end{array}$ & \\
\hline Industry Experience & $(-)$ & & & & & $\begin{array}{c}0.071 \\
(0.282)\end{array}$ \\
\hline
\end{tabular}

Panel D: The Book-to-Market Beta from the Four-Factor Model

\begin{tabular}{|c|c|c|c|c|c|c|}
\hline & & (1) & (2) & (3) & (4) & (5) \\
\hline \multicolumn{7}{|l|}{ CEO Employment History Variables } \\
\hline \# Employers & $(+)$ & $\begin{array}{l}0.032 * \\
(0.083)\end{array}$ & & & & \\
\hline \# Employer Changes per year & $(+)$ & & $\begin{array}{l}1.098^{*} \\
(0.062)\end{array}$ & & & \\
\hline Employer Change Recency & $(+)$ & & & $\begin{array}{c}0.047 \\
(0.110)\end{array}$ & & \\
\hline Firm Experience Diversification & $(-)$ & & & & $\begin{array}{l}-0.162 \\
(0.124)\end{array}$ & \\
\hline Industry Experience & $(-)$ & & & & & $\begin{array}{l}-0.120 \\
(0.115)\end{array}$ \\
\hline
\end{tabular}

Panel E: The Momentum Beta from the Four-Factor Model

\begin{tabular}{|c|c|c|c|c|c|c|}
\hline & & $(1)$ & (2) & (3) & (4) & (5) \\
\hline \multicolumn{7}{|l|}{ CEO Employment History Variables } \\
\hline \# Employers & $(+)$ & $\begin{array}{c}0.010 \\
(0.408)\end{array}$ & & & & \\
\hline \# Employer Changes per year & $(+)$ & & $\begin{array}{c}0.351 \\
(0.377)\end{array}$ & & & \\
\hline Employer Change Recency & $(+)$ & & & $\begin{array}{c}0.019 \\
(0.332)\end{array}$ & & \\
\hline Firm Experience Diversification & $(-)$ & & & & $\begin{array}{l}-0.074 \\
(0.284)\end{array}$ & \\
\hline Industry Experience & $(-)$ & & & & & $\begin{array}{c}-0.053 \\
(0.295)\end{array}$ \\
\hline
\end{tabular}


Table 15 Continued.

Panel F. CEO Employment History and Segment Herfindhal Index

\begin{tabular}{|c|c|c|c|c|c|c|c|c|}
\hline & & Opera & & & & Operating & & \\
\hline & Sales & Ince & CAPEX & Assets & Sales & & CAPEX & Assets \\
\hline \#Employers & $\begin{array}{c}-0.022 * * * \\
(0.003)\end{array}$ & $\begin{array}{c}-0.115^{* *} \\
(0.047)\end{array}$ & $\begin{array}{c}-0.017 * * \\
(0.031)\end{array}$ & $\begin{array}{l}-0.014 * \\
(0.071)\end{array}$ & & & & \\
\hline $\begin{array}{l}\text { Industry Experience } \\
\text { Diversification }\end{array}$ & & & & & $\begin{array}{l}0.064 * \\
(0.060)\end{array}$ & $\begin{array}{l}0.482 * * \\
(0.023)\end{array}$ & $\begin{array}{l}0.090^{* *} \\
(0.030)\end{array}$ & $\begin{array}{c}0.066 \\
(0.115)\end{array}$ \\
\hline Firm Characteristics & & & & & & & & \\
\hline Pre-turnover HHI & $\begin{array}{c}0.576^{* * *} \\
(0.000)\end{array}$ & $\begin{array}{c}0.110 \\
(0.186)\end{array}$ & $\begin{array}{c}0.570 * * * \\
(0.000)\end{array}$ & $\begin{array}{c}0.576^{* * *} \\
(0.000)\end{array}$ & $\begin{array}{c}0.568 * * * \\
(0.000)\end{array}$ & $\begin{array}{c}0.109 \\
(0.195)\end{array}$ & $\begin{array}{c}0.566^{* * *} \\
(0.000)\end{array}$ & $\begin{array}{c}0.569 * * * \\
(0.000)\end{array}$ \\
\hline $\ln$ (Total Sales) & $\begin{array}{c}-0.039^{* * *} \\
(0.000)\end{array}$ & $\begin{array}{r}-0.094 * * \\
(0.013)\end{array}$ & $\begin{array}{c}-0.035^{* * *} \\
(0.000)\end{array}$ & $\begin{array}{c}-0.034 * * * \\
(0.000)\end{array}$ & $\begin{array}{c}-0.035^{* * *} \\
(0.000)\end{array}$ & $\begin{array}{c}-0.074 * * \\
(0.031)\end{array}$ & $\begin{array}{c}-0.032 * * * \\
(0.000)\end{array}$ & $\begin{array}{c}-0.032 * * * \\
(0.000)\end{array}$ \\
\hline Firm Age & $\begin{array}{c}0.004 \\
(0.720)\end{array}$ & $\begin{array}{l}-0.042 \\
(0.537)\end{array}$ & $\begin{array}{l}-0.012 \\
(0.278)\end{array}$ & $\begin{array}{l}-0.003 \\
(0.800)\end{array}$ & $\begin{array}{c}0.007 \\
(0.519)\end{array}$ & $\begin{array}{l}-0.031 \\
(0.635)\end{array}$ & $\begin{array}{l}-0.011 \\
(0.314)\end{array}$ & $\begin{array}{l}-0.002 \\
(0.860)\end{array}$ \\
\hline Surplus Cash & $\begin{array}{l}0.050 \\
(0.405)\end{array}$ & $\begin{array}{c}-2.023 * * * \\
(0.000)\end{array}$ & $\begin{array}{l}-0.026 \\
(0.631)\end{array}$ & $\begin{array}{c}0.057 \\
(0.378)\end{array}$ & $\begin{array}{c}0.069 \\
(0.258)\end{array}$ & $\begin{array}{c}-1.933 * * * \\
(0.001)\end{array}$ & $\begin{array}{l}-0.014 \\
(0.797)\end{array}$ & $\begin{array}{c}0.068 \\
(0.291)\end{array}$ \\
\hline Tobin's Q & $\begin{array}{l}0.009^{*} \\
(0.082)\end{array}$ & $\begin{array}{l}-0.070 \\
(0.101)\end{array}$ & $\begin{array}{l}0.006 \\
(0.174)\end{array}$ & $\begin{array}{l}0.005 \\
(0.309)\end{array}$ & $\begin{array}{l}0.009^{*} \\
(0.089)\end{array}$ & $\begin{array}{l}-0.069 \\
(0.105)\end{array}$ & $\begin{array}{c}0.007 \\
(0.137)\end{array}$ & $\begin{array}{l}0.005 \\
(0.309)\end{array}$ \\
\hline R\&D/Total Assets & $\begin{array}{c}0.189 \\
(0.330)\end{array}$ & $\begin{array}{c}5.873 * * * \\
(0.001)\end{array}$ & $\begin{array}{c}0.279 \\
(0.135)\end{array}$ & $\begin{array}{c}0.561 * * * \\
(0.001)\end{array}$ & $\begin{array}{c}0.178 \\
(0.358)\end{array}$ & $\begin{array}{c}5.753 * * * \\
(0.001)\end{array}$ & $\begin{array}{c}0.264 \\
(0.159)\end{array}$ & $\begin{array}{c}0.553 * * * \\
(0.001)\end{array}$ \\
\hline & $(0.210)$ & $\begin{array}{l}0.269 \\
(0.723)\end{array}$ & $\begin{array}{l}0.415 \\
(0.197)\end{array}$ & $\begin{array}{c}0.281 \\
(0.123)\end{array}$ & $\begin{array}{c}0.315 \\
(0.261)\end{array}$ & $\begin{array}{c}0.244 \\
(0.774)\end{array}$ & $\begin{array}{c}0.324 \\
(0.217)\end{array}$ & $\begin{array}{l}0.270 \\
(0.127)\end{array}$ \\
\hline CAPEXP & $\begin{array}{l}0.005 \\
(0.972)\end{array}$ & $\begin{array}{l}1.154 \\
(0.233)\end{array}$ & $\begin{array}{l}0.323 * * \\
(0.018)\end{array}$ & $\begin{array}{c}0.071 \\
(0.637)\end{array}$ & $\begin{array}{c}0.016 \\
(0.914)\end{array}$ & $\begin{array}{l}1.156 \\
(0.230)\end{array}$ & $\begin{array}{l}0.301 * * \\
(0.029)\end{array}$ & $\begin{array}{c}0.060 \\
(0.692)\end{array}$ \\
\hline Leverage & $\begin{array}{l}0.021 \\
(0.635)\end{array}$ & $\begin{array}{c}0.149 \\
(0.698)\end{array}$ & $\begin{array}{c}0.039 \\
(0.401)\end{array}$ & $\begin{array}{c}0.008 \\
(0.863)\end{array}$ & $\begin{array}{c}0.009 \\
(0.832)\end{array}$ & $\begin{array}{c}0.126 \\
(0.742)\end{array}$ & $\begin{array}{c}0.035 \\
(0.444)\end{array}$ & $\begin{array}{c}0.003 \\
(0.950)\end{array}$ \\
\hline $\begin{array}{l}\text { Pay Directors Equity } \\
\text { Based Compensation }\end{array}$ & $\begin{array}{c}0.001 \\
(0.955)\end{array}$ & $\begin{array}{l}0.060 \\
(0.557)\end{array}$ & $\begin{array}{l}-0.000 \\
(0.974)\end{array}$ & $\begin{array}{c}0.004 \\
(0.793)\end{array}$ & $\begin{array}{l}-0.001 \\
(0.926)\end{array}$ & $\begin{array}{c}0.056 \\
(0.586)\end{array}$ & $\begin{array}{l}-0.000 \\
(0.974)\end{array}$ & $\begin{array}{c}0.003 \\
(0.843)\end{array}$ \\
\hline $\begin{array}{l}\text { Activist Institutional } \\
\text { Holding }(\%)\end{array}$ & $\begin{array}{l}-0.426 \\
(0.230)\end{array}$ & $\begin{array}{l}-1.299 \\
(0.650)\end{array}$ & $\begin{array}{l}-0.377 \\
(0.347)\end{array}$ & $\begin{array}{l}-0.661^{*} \\
(0.077)\end{array}$ & $\begin{array}{l}-0.417 \\
(0.243)\end{array}$ & $\begin{array}{l}-1.327 \\
(0.644)\end{array}$ & $\begin{array}{l}-0.382 \\
(0.343)\end{array}$ & $\begin{array}{l}-0.660^{*} \\
(0.082)\end{array}$ \\
\hline $\begin{array}{l}\text { CEO Cash } \\
\text { Compensation }\end{array}$ & $\begin{array}{l}-0.029^{*} \\
(0.051)\end{array}$ & $\begin{array}{l}0.113 \\
(0.349)\end{array}$ & $\begin{array}{c}-0.032 * * \\
(0.030)\end{array}$ & $\begin{array}{l}-0.018 \\
(0.219)\end{array}$ & $\begin{array}{l}-0.027^{*} \\
(0.065)\end{array}$ & $\begin{array}{c}0.116 \\
(0.336)\end{array}$ & $\begin{array}{c}-0.030^{* *} \\
(0.043)\end{array}$ & $\begin{array}{l}-0.017 \\
(0.255)\end{array}$ \\
\hline $\begin{array}{l}\text { CEO Compensation } \\
\text { Delta }\end{array}$ & $\begin{array}{l}-0.004 \\
(0.658)\end{array}$ & $\begin{array}{l}-0.064 \\
(0.126)\end{array}$ & $\begin{array}{l}-0.006 \\
(0.595)\end{array}$ & $\begin{array}{l}-0.007 \\
(0.402)\end{array}$ & $\begin{array}{l}-0.004 \\
(0.609)\end{array}$ & $\begin{array}{l}-0.066 \\
(0.115)\end{array}$ & $\begin{array}{l}-0.006 \\
(0.592)\end{array}$ & $\begin{array}{l}-0.007 \\
(0.386)\end{array}$ \\
\hline $\begin{array}{l}\text { CEO Compensation } \\
\text { Vega }\end{array}$ & $\begin{array}{l}0.045^{* *} \\
(0.016)\end{array}$ & $\begin{array}{l}-0.006 \\
(0.952)\end{array}$ & $\begin{array}{c}0.023 \\
(0.334)\end{array}$ & $\begin{array}{l}0.036^{*} \\
(0.083)\end{array}$ & $\begin{array}{l}0.042^{* *} \\
(0.023)\end{array}$ & $\begin{array}{l}-0.018 \\
(0.849)\end{array}$ & $\begin{array}{c}0.022 \\
(0.350)\end{array}$ & $\begin{array}{l}0.035^{*} \\
(0.084)\end{array}$ \\
\hline Herfindhal Index & $\begin{array}{c}-0.437 * * \\
(0.039)\end{array}$ & $\begin{array}{l}-0.543 \\
(0.415)\end{array}$ & $\begin{array}{c}0.052 \\
(0.686)\end{array}$ & $\begin{array}{c}-0.588^{* *} \\
(0.028)\end{array}$ & $\begin{array}{c}-0.443 * * \\
(0.033)\end{array}$ & $\begin{array}{l}-0.590 \\
(0.362)\end{array}$ & $\begin{array}{c}0.041 \\
(0.744)\end{array}$ & $\begin{array}{c}-0.596^{* *} \\
(0.024)\end{array}$ \\
\hline CEO Cho & & & & & & & & \\
\hline $\mathrm{Ln}(\mathrm{CEO} \mathrm{T}$ & $\begin{array}{c}-0.050^{* * *} \\
(0.000)\end{array}$ & $\begin{array}{l}-0.148 \\
(0.125)\end{array}$ & $\begin{array}{c}-0.034 * * * \\
(0.002)\end{array}$ & $\begin{array}{c}-0.045^{* * *} \\
(0.000)\end{array}$ & $\begin{array}{c}-0.043 * * * \\
(0.000)\end{array}$ & $\begin{array}{l}-0.113 \\
(0.217)\end{array}$ & $\begin{array}{c}-0.030^{* * *} \\
(0.004)\end{array}$ & $\begin{array}{c}-0.042 * * * \\
(0.000)\end{array}$ \\
\hline CEO Age & $\begin{array}{c}0.049 \\
(0.386)\end{array}$ & $\begin{array}{l}-0.210 \\
(0.667)\end{array}$ & $\begin{array}{c}0.017 \\
(0.780)\end{array}$ & $\begin{array}{c}0.061 \\
(0.296)\end{array}$ & $\begin{array}{c}0.003 \\
(0.957)\end{array}$ & $\begin{array}{l}-0.405 \\
(0.364)\end{array}$ & $\begin{array}{l}-0.005 \\
(0.939)\end{array}$ & $\begin{array}{c}0.039 \\
(0.487)\end{array}$ \\
\hline $\operatorname{MBA}(0 / 1)$ & $\begin{array}{l}-0.006 \\
(0.667)\end{array}$ & $\begin{array}{l}0.182^{*} \\
(0.060)\end{array}$ & $\begin{array}{c}-0.004 \\
(0.753)\end{array}$ & $\begin{array}{c}0.001 \\
(0.913)\end{array}$ & $\begin{array}{l}-0.010 \\
(0.429)\end{array}$ & $\begin{array}{l}0.163^{*} \\
(0.081)\end{array}$ & $\begin{array}{l}-0.004 \\
(0.741)\end{array}$ & $\begin{array}{c}0.001 \\
(0.952)\end{array}$ \\
\hline Founder $(0 / 1)$ & $\begin{array}{c}0.016 \\
(0.495)\end{array}$ & $\begin{array}{c}0.059 \\
(0.799)\end{array}$ & $\begin{array}{c}-0.005 \\
(0.818)\end{array}$ & $\begin{array}{c}0.022 \\
(0.354)\end{array}$ & $\begin{array}{c}0.030 \\
(0.160)\end{array}$ & $\begin{array}{c}0.114 \\
(0.596)\end{array}$ & $\begin{array}{c}0.000 \\
(0.989)\end{array}$ & $\begin{array}{c}0.028 \\
(0.218)\end{array}$ \\
\hline \# Functional Areas & $\begin{array}{c}0.014^{* *} \\
(0.042)\end{array}$ & $\begin{array}{c}0.099 \\
(0.141) \\
\end{array}$ & $\begin{array}{c}0.010 \\
(0.146) \\
\end{array}$ & $\begin{array}{c}0.013^{*} \\
(0.063)\end{array}$ & $\begin{array}{l}0.011^{*} \\
(0.096)\end{array}$ & $\begin{array}{c}0.089 \\
(0.188) \\
\end{array}$ & $\begin{array}{c}0.009 \\
(0.179) \\
\end{array}$ & $\begin{array}{c}0.012^{*} \\
(0.078)\end{array}$ \\
\hline
\end{tabular}


Table 15 Continued

\begin{tabular}{|c|c|c|c|c|c|c|c|c|}
\hline $\begin{array}{l}\text { Has Finance } \\
\text { Background }(0 / 1)\end{array}$ & $\begin{array}{l}-0.009 \\
(0.571)\end{array}$ & $\begin{array}{l}-0.102 \\
(0.388)\end{array}$ & $\begin{array}{l}-0.010 \\
(0.551)\end{array}$ & $\begin{array}{c}0.003 \\
(0.840)\end{array}$ & $\begin{array}{l}-0.008 \\
(0.612)\end{array}$ & $\begin{array}{l}-0.091 \\
(0.437)\end{array}$ & $\begin{array}{l}-0.006 \\
(0.723)\end{array}$ & $\begin{array}{c}0.006 \\
(0.711)\end{array}$ \\
\hline Constant & $\begin{array}{c}0.092 \\
(0.716)\end{array}$ & $\begin{array}{c}2.247 \\
(0.185)\end{array}$ & $\begin{array}{l}0.507^{* *} \\
(0.038)\end{array}$ & $\begin{array}{c}0.095 \\
(0.747)\end{array}$ & $\begin{array}{c}0.144 \\
(0.571)\end{array}$ & $\begin{array}{l}2.350 \\
(0.156)\end{array}$ & $\begin{array}{l}0.479 * \\
(0.052)\end{array}$ & $\begin{array}{c}0.089 \\
(0.762)\end{array}$ \\
\hline Year Dummies & Yes & Yes & Yes & Yes & Yes & Yes & Yes & Yes \\
\hline Industry Dummies & Yes & Yes & Yes & Yes & Yes & Yes & Yes & Yes \\
\hline Observations & 4869 & 4137 & 4036 & 4363 & 4869 & 4137 & 4036 & 4363 \\
\hline R-squared & 0.525 & 0.068 & 0.544 & 0.554 & 0.528 & 0.070 & 0.548 & 0.554 \\
\hline $\begin{array}{l}\text { Hansen's J-test (p-value) } \\
\text { First-stage } F \text {-stat for }\end{array}$ & 0.556 & 0.252 & 0.632 & 0.345 & 0.498 & 0.373 & 0.619 & 0.233 \\
\hline Principal Comp. One & 83.69 & 40.5 & 74.08 & 77.65 & 299.17 & 253.38 & 188.47 & 204.94 \\
\hline
\end{tabular}

Panel G. CEO Employment History and the likelihoods of Add or Reduce a Segment

\begin{tabular}{|c|c|c|c|c|c|c|c|c|}
\hline \#Employers & $\begin{array}{c}\text { Reduce } \\
\text { SIC Code } \\
0.048 \\
(0.414)\end{array}$ & $\begin{array}{c}\text { Add } \\
\text { SIC Code } \\
0.198^{* * *} \\
(0.000)\end{array}$ & $\begin{array}{c}\text { Reduce } \\
\text { Segment } \\
0.058 \\
(0.361)\end{array}$ & $\begin{array}{c}\text { Add } \\
\text { Segment } \\
0.186^{* * *} \\
(0.000)\end{array}$ & $\begin{array}{l}\text { Reduce } \\
\text { SIC Code }\end{array}$ & $\begin{array}{c}\text { Add } \\
\text { SIC Code }\end{array}$ & $\begin{array}{l}\text { Reduce } \\
\text { Segment }\end{array}$ & $\begin{array}{c}\text { Add } \\
\text { Segment }\end{array}$ \\
\hline $\begin{array}{l}\text { Industry Experience } \\
\text { Diversification } \\
\text { Firm Characteristics }\end{array}$ & & & & & $\begin{array}{c}-0.991 * * \\
(0.031)\end{array}$ & $\begin{array}{c}-1.476^{* * *} \\
(0.000)\end{array}$ & $\begin{array}{c}-1.174 * * \\
(0.010)\end{array}$ & $\begin{array}{c}-1.053 * * * \\
(0.001)\end{array}$ \\
\hline$\overline{\text { Pre-turnover \#Seg/Sic }}$ & $\begin{array}{c}1.293 * * * \\
(0.000)\end{array}$ & $\begin{array}{c}-0.298 * * \\
(0.013)\end{array}$ & $\begin{array}{c}1.143 * * * \\
(0.000)\end{array}$ & $\begin{array}{l}-0.110 \\
(0.162)\end{array}$ & $\begin{array}{c}1.286^{* * *} \\
(0.000)\end{array}$ & $\begin{array}{c}-0.308 * * \\
(0.011)\end{array}$ & $\begin{array}{c}1.140 * * * \\
(0.000)\end{array}$ & $\begin{array}{l}-0.123 \\
(0.115)\end{array}$ \\
\hline $\ln$ (Total Sales) & $\begin{array}{c}-0.198 * * \\
(0.049)\end{array}$ & $\begin{array}{c}0.506^{* * *} \\
(0.000)\end{array}$ & $\begin{array}{c}-0.318^{* * *} \\
(0.004)\end{array}$ & $\begin{array}{c}0.357 * * * \\
(0.000)\end{array}$ & $\begin{array}{l}-0.183^{*} \\
(0.073)\end{array}$ & $\begin{array}{c}0.485^{* * *} \\
(0.000)\end{array}$ & $\begin{array}{c}-0.299 * * * \\
(0.007)\end{array}$ & $\begin{array}{c}0.330 * * * \\
(0.000)\end{array}$ \\
\hline Firm Age & $\begin{array}{l}0.073 \\
(0.661)\end{array}$ & $\begin{array}{l}-0.010 \\
(0.944)\end{array}$ & $\begin{array}{l}-0.179 \\
(0.311)\end{array}$ & $\begin{array}{l}-0.041 \\
(0.739)\end{array}$ & $\begin{array}{c}0.126 \\
(0.456)\end{array}$ & $\begin{array}{c}0.002 \\
(0.987)\end{array}$ & $\begin{array}{l}-0.128 \\
(0.466)\end{array}$ & $\begin{array}{l}-0.041 \\
(0.737)\end{array}$ \\
\hline Surplus Cash & $\begin{array}{l}1.108 \\
(0.356)\end{array}$ & $\begin{array}{c}-2.440 * * \\
(0.028)\end{array}$ & $\begin{array}{c}0.642 \\
(0.603)\end{array}$ & $\begin{array}{l}-1.366^{*} \\
(0.094)\end{array}$ & $\begin{array}{l}1.062 \\
(0.376)\end{array}$ & $\begin{array}{c}-2.626^{* *} \\
(0.020)\end{array}$ & $\begin{array}{c}0.672 \\
(0.582)\end{array}$ & $\begin{array}{l}-1.549^{*} \\
(0.063)\end{array}$ \\
\hline Tobin's Q & $\begin{array}{c}-0.244 * * \\
(0.020)\end{array}$ & $\begin{array}{l}-0.186 \\
(0.127)\end{array}$ & $\begin{array}{c}-0.278^{* *} \\
(0.018)\end{array}$ & $\begin{array}{c}-0.190^{* *} \\
(0.019)\end{array}$ & $\begin{array}{c}-0.254^{* *} \\
(0.015)\end{array}$ & $\begin{array}{l}-0.180 \\
(0.159)\end{array}$ & $\begin{array}{c}-0.289 * * \\
(0.011)\end{array}$ & $\begin{array}{c}-0.181^{* *} \\
(0.030)\end{array}$ \\
\hline R\&D/Total Assets & $\begin{array}{l}-5.180 \\
(0.147)\end{array}$ & $\begin{array}{c}-0.446 \\
(0.865) \\
4.438 \\
(0.201)\end{array}$ & $\begin{array}{l}-3.225 \\
(0.399) \\
-4.867 \\
(0.797)\end{array}$ & $\begin{array}{c}1.999 \\
(0.312) \\
0.962 \\
(0.118)\end{array}$ & $\begin{array}{c}-4.894 \\
(0.166) \\
-4.518 \\
(0.300)\end{array}$ & $\begin{array}{c}-0.561 \\
(0.835) \\
4.173 \\
(0.174)\end{array}$ & $\begin{array}{l}-2.931 \\
(0.436) \\
-5.078 \\
(0.833)\end{array}$ & $\begin{array}{c}1.997 \\
(0.319) \\
0.780 \\
(0.117)\end{array}$ \\
\hline CAPEXP & $\begin{array}{c}-5.186^{* *} \\
(0.035)\end{array}$ & $\begin{array}{c}-4.991 * * \\
(0.044)\end{array}$ & $\begin{array}{l}-4.398^{*} \\
(0.099)\end{array}$ & $\begin{array}{l}-1.286 \\
(0.507)\end{array}$ & $\begin{array}{l}-4.577^{*} \\
(0.063)\end{array}$ & $\begin{array}{l}-4.415^{*} \\
(0.068)\end{array}$ & $\begin{array}{l}-3.715 \\
(0.166)\end{array}$ & $\begin{array}{l}-1.160 \\
(0.554)\end{array}$ \\
\hline Leverage & $\begin{array}{l}-0.530 \\
(0.469)\end{array}$ & $\begin{array}{l}-0.774 \\
(0.214)\end{array}$ & $\begin{array}{l}-0.053 \\
(0.944)\end{array}$ & $\begin{array}{c}0.280 \\
(0.593)\end{array}$ & $\begin{array}{l}-0.611 \\
(0.406)\end{array}$ & $\begin{array}{l}-0.804 \\
(0.197)\end{array}$ & $\begin{array}{l}-0.180 \\
(0.812)\end{array}$ & $\begin{array}{c}0.312 \\
(0.552)\end{array}$ \\
\hline $\begin{array}{l}\text { Pay Directors Equity } \\
\text { Based Compensation }\end{array}$ & $\begin{array}{l}0.493^{*} \\
(0.091)\end{array}$ & $\begin{array}{c}0.109 \\
(0.608)\end{array}$ & $\begin{array}{c}0.274 \\
(0.328)\end{array}$ & $\begin{array}{c}0.093 \\
(0.580)\end{array}$ & $\begin{array}{c}0.475 \\
(0.103)\end{array}$ & $\begin{array}{c}0.111 \\
(0.596)\end{array}$ & $\begin{array}{c}0.266 \\
(0.345)\end{array}$ & $\begin{array}{c}0.097 \\
(0.559)\end{array}$ \\
\hline $\begin{array}{l}\text { Activist Institutional } \\
\text { Holding }(\%)\end{array}$ & $\begin{array}{l}-3.760 \\
(0.614)\end{array}$ & $\begin{array}{l}-2.850 \\
(0.645)\end{array}$ & $\begin{array}{l}-6.157 \\
(0.423)\end{array}$ & $\begin{array}{c}0.409 \\
(0.939)\end{array}$ & $\begin{array}{l}-3.452 \\
(0.640)\end{array}$ & $\begin{array}{l}-2.908 \\
(0.638)\end{array}$ & $\begin{array}{l}-5.672 \\
(0.453)\end{array}$ & $\begin{array}{c}0.137 \\
(0.980)\end{array}$ \\
\hline $\begin{array}{l}\text { CEO Cash } \\
\text { Compensation }\end{array}$ & $\begin{array}{l}-0.173 \\
(0.582)\end{array}$ & $\begin{array}{c}0.157 \\
(0.502)\end{array}$ & $\begin{array}{c}-0.674 * * * \\
(0.010)\end{array}$ & $\begin{array}{c}0.069 \\
(0.705)\end{array}$ & $\begin{array}{l}-0.184 \\
(0.553)\end{array}$ & $\begin{array}{l}0.155 \\
(0.522)\end{array}$ & $\begin{array}{c}-0.702 * * * \\
(0.006)\end{array}$ & $\begin{array}{c}0.059 \\
(0.754)\end{array}$ \\
\hline $\begin{array}{l}\text { CEO Compensation } \\
\text { Delta }\end{array}$ & $\begin{array}{l}-0.156 \\
(0.546)\end{array}$ & $\begin{array}{c}0.054 \\
(0.655)\end{array}$ & $\begin{array}{l}-0.205 \\
(0.334)\end{array}$ & $\begin{array}{l}-0.004 \\
(0.968)\end{array}$ & $\begin{array}{l}-0.148 \\
(0.572)\end{array}$ & $\begin{array}{c}0.057 \\
(0.654)\end{array}$ & $\begin{array}{l}-0.187 \\
(0.387)\end{array}$ & $\begin{array}{l}-0.001 \\
(0.993)\end{array}$ \\
\hline
\end{tabular}


Table 15 Continued

\begin{tabular}{|c|c|c|c|c|c|c|c|c|}
\hline \multicolumn{9}{|c|}{ Firm Characteristics (Continued) } \\
\hline $\begin{array}{l}\text { CEO Compensation } \\
\text { Vega }\end{array}$ & $\begin{array}{c}0.208 \\
(0.660)\end{array}$ & $\begin{array}{l}-0.175 \\
(0.485)\end{array}$ & $\begin{array}{c}0.323 \\
(0.362)\end{array}$ & $\begin{array}{l}-0.190 \\
(0.417)\end{array}$ & $\begin{array}{c}0.158 \\
(0.740)\end{array}$ & $\begin{array}{l}-0.189 \\
(0.449)\end{array}$ & $\begin{array}{c}0.234 \\
(0.514)\end{array}$ & $\begin{array}{l}-0.190 \\
(0.416)\end{array}$ \\
\hline Herfindhal Index & $\begin{array}{c}0.197 \\
(0.935)\end{array}$ & $\begin{array}{c}4.289 \\
(0.217)\end{array}$ & $\begin{array}{c}2.068 \\
(0.321)\end{array}$ & $\begin{array}{c}3.339 \\
(0.262)\end{array}$ & $\begin{array}{c}0.017 \\
(0.994)\end{array}$ & $\begin{array}{c}3.685 \\
(0.327)\end{array}$ & $\begin{array}{l}1.906 \\
(0.359)\end{array}$ & $\begin{array}{c}2.701 \\
(0.379)\end{array}$ \\
\hline \multicolumn{9}{|l|}{ CEO Characteristics } \\
\hline$\overline{\operatorname{Ln}(\text { CEO Tenure }+1)}$ & $\begin{array}{c}0.515 * * * \\
(0.007)\end{array}$ & $\begin{array}{c}0.930 * * * \\
(0.000)\end{array}$ & $\begin{array}{l}0.400 * * \\
(0.035)\end{array}$ & $\begin{array}{c}0.962 * * * \\
(0.000)\end{array}$ & $\begin{array}{c}0.523 * * * \\
(0.007)\end{array}$ & $\begin{array}{c}0.894 * * * \\
(0.000)\end{array}$ & $\begin{array}{c}0.409 * * \\
(0.033)\end{array}$ & $\begin{array}{c}0.903 * * * \\
(0.000)\end{array}$ \\
\hline CEO Age & $\begin{array}{c}0.324 \\
(0.731)\end{array}$ & $\begin{array}{l}-0.654 \\
(0.393)\end{array}$ & $\begin{array}{c}1.199 \\
(0.225)\end{array}$ & $\begin{array}{l}-0.170 \\
(0.801)\end{array}$ & $\begin{array}{c}0.217 \\
(0.821)\end{array}$ & $\begin{array}{l}-0.457 \\
(0.545)\end{array}$ & $\begin{array}{c}1.078 \\
(0.274)\end{array}$ & $\begin{array}{c}0.123 \\
(0.850)\end{array}$ \\
\hline $\operatorname{MBA}(0 / 1)$ & $\begin{array}{c}-0.507^{* *} \\
(0.037)\end{array}$ & $\begin{array}{l}-0.018 \\
(0.925)\end{array}$ & $\begin{array}{l}-0.179 \\
(0.469)\end{array}$ & $\begin{array}{c}0.030 \\
(0.849)\end{array}$ & $\begin{array}{c}-0.539^{* *} \\
(0.028)\end{array}$ & $\begin{array}{l}-0.040 \\
(0.833)\end{array}$ & $\begin{array}{l}-0.208 \\
(0.392)\end{array}$ & $\begin{array}{c}0.031 \\
(0.842)\end{array}$ \\
\hline Founder $(0 / 1)$ & $\begin{array}{l}-0.532 \\
(0.217)\end{array}$ & $\begin{array}{l}-0.403 \\
(0.223)\end{array}$ & $\begin{array}{c}0.035 \\
(0.930)\end{array}$ & $\begin{array}{l}-0.292 \\
(0.293)\end{array}$ & $\begin{array}{l}-0.458 \\
(0.287)\end{array}$ & $\begin{array}{l}-0.380 \\
(0.251)\end{array}$ & $\begin{array}{c}0.141 \\
(0.727)\end{array}$ & $\begin{array}{l}-0.327 \\
(0.243)\end{array}$ \\
\hline \# Functional Areas & $\begin{array}{c}0.180 \\
(0.173)\end{array}$ & $\begin{array}{l}-0.051 \\
(0.629)\end{array}$ & $\begin{array}{l}-0.012 \\
(0.927)\end{array}$ & $\begin{array}{l}-0.143 * \\
(0.097)\end{array}$ & $\begin{array}{c}0.168 \\
(0.202)\end{array}$ & $\begin{array}{l}-0.039 \\
(0.704)\end{array}$ & $\begin{array}{l}-0.028 \\
(0.822)\end{array}$ & $\begin{array}{l}-0.130 \\
(0.129)\end{array}$ \\
\hline $\begin{array}{l}\text { Has Finance } \\
\text { Background }(0 / 1)\end{array}$ & $\begin{array}{l}-0.272 \\
(0.311)\end{array}$ & $\begin{array}{l}-0.339 \\
(0.131)\end{array}$ & $\begin{array}{l}-0.086 \\
(0.768)\end{array}$ & $\begin{array}{c}0.095 \\
(0.592)\end{array}$ & $\begin{array}{l}-0.319 \\
(0.234)\end{array}$ & $\begin{array}{l}-0.429 * \\
(0.057)\end{array}$ & $\begin{array}{l}-0.141 \\
(0.629)\end{array}$ & $\begin{array}{c}0.053 \\
(0.768)\end{array}$ \\
\hline Constant & $\begin{array}{l}-6.812 * \\
(0.058)\end{array}$ & $\begin{array}{l}-2.635 \\
(0.415)\end{array}$ & $\begin{array}{l}-6.457^{*} \\
(0.088)\end{array}$ & $\begin{array}{l}-4.286 \\
(0.135)\end{array}$ & $\begin{array}{l}-5.851 \\
(0.111)\end{array}$ & $\begin{array}{l}-1.721 \\
(0.597)\end{array}$ & $\begin{array}{l}-5.304 \\
(0.163)\end{array}$ & $\begin{array}{l}-3.919 \\
(0.170)\end{array}$ \\
\hline Year Dummies & Yes & Yes & Yes & Yes & Yes & Yes & Yes & Yes \\
\hline Industry Dummies & Yes & Yes & Yes & Yes & Yes & Yes & Yes & Yes \\
\hline Observations & 4873 & 4873 & 4873 & 4873 & 4873 & 4873 & 4873 & 4873 \\
\hline Pseudo R2 & 0.271 & 0.271 & 0.241 & 0.241 & 0.273 & 0.273 & 0.241 & 0.241 \\
\hline
\end{tabular}


Table 16. The Principal Component of CEO Employment History Variables, Firm Policies and Risk

This table presents IV/2SLS results for firm policies and risk using the first component from the principal component analysis to proxy for CEO employment history. The dependent variables are listed at the top of each column. Refer to Section 5.5 for details on the five equations. Refer to Table 1 and Appendix A for variable definitions. Pre-turnover firm policies are the respective firm policies in the year before the CEO turnover year. Instrumental variables for the principal component are the unemployment rate for the year when the CEO started his first full-time job, non-business career dummy that equals one if the CEO had academic or government jobs, and the number of years the CEO has worked in his current firm's industry. The instrumental variable for CEO employment history*Industry Homogeneity in the R\&D regression is the unemployment rate described above multiplied by industry homogeneity. The predicted signs for the CEO employment history proxies are presented in parenthesis at the top of each column. Panel A presents loadings of the five CEO employment history proxies on the five principal components. ${ }^{* *}, * *$, and $*$ indicate significance at the 1,5 , and $10 \%$ levels, respectively.

Panel A. Principal Components Analysis of CEO Employment History Variables

\begin{tabular}{lccccc}
\hline Variables & Component 1 & Component 2 & Component 3 & Component 4 & Component 5 \\
\hline \# Employers & 0.476 & 0.253 & 0.136 & -0.029 & 0.831 \\
\# Employer Changes per year & 0.456 & 0.338 & 0.278 & -0.644 & -0.432 \\
Employer Change Recency & 0.457 & 0.281 & 0.134 & 0.759 & -0.343 \\
Firm Experience Diversification & -0.456 & 0.169 & 0.866 & 0.092 & 0.072 \\
Industry Experience Diversification & -0.385 & 0.845 & -0.369 & -0.005 & 0.024 \\
Eigenvalues & 4.036 & 0.525 & 0.192 & 0.179 & 0.069 \\
Cumulative Proportions & $80.71 \%$ & $91.21 \%$ & $95.04 \%$ & $98.63 \%$ & $100.00 \%$ \\
\hline
\end{tabular}

Panel B. Firm Policies, Risk, and The First Principal Component

\begin{tabular}{|c|c|c|c|c|c|c|c|c|}
\hline & Leverage & CAPEXP & $R \& D$ & Adv. & $\begin{array}{c}\text { Total Risk } \\
\text { (Ann. Stock } \\
\text { Return Std.) }\end{array}$ & $\begin{array}{c}\text { Market } \\
\text { Risk } \\
\text { (CAPM) }\end{array}$ & $\begin{array}{l}\text { Firm- } \\
\text { specific } \\
\text { Risk } \\
\text { (CAPM) } \\
\end{array}$ & $\begin{array}{c}\text { Firm- } \\
\text { specific } \\
\text { Risk } \\
\text { (4- Factor) }\end{array}$ \\
\hline & $(+)$ & $(-)$ & $(+)$ & $(+)$ & $(+)$ & $(+)$ & $(+)$ & $(+)$ \\
\hline Principal Component 1 & $\begin{array}{l}0.009 * * \\
(0.024)\end{array}$ & $\begin{array}{c}-0.003 * * * \\
(0.005)\end{array}$ & $\begin{array}{c}-0.005^{* * *} \\
(0.007)\end{array}$ & $\begin{array}{l}0.001^{*} \\
(0.092)\end{array}$ & $\begin{array}{l}0.004^{*} \\
(0.093)\end{array}$ & $\begin{array}{l}-0.011 \\
(0.257)\end{array}$ & $\begin{array}{l}0.004 * * \\
(0.034)\end{array}$ & $\begin{array}{l}0.005^{* *} \\
(0.015)\end{array}$ \\
\hline $\begin{array}{l}\text { Prin. Comp. } 1 * \text { Ind. } \\
\text { Homogeneity } \\
\text { Firm Characteristics }\end{array}$ & & & $\begin{array}{l}0.017^{*} \\
(0.060)\end{array}$ & & & & & \\
\hline Pre-turnover Policy & $\begin{array}{c}0.309 * * * \\
(0.000)\end{array}$ & $\begin{array}{c}0.304 * * * \\
(0.000)\end{array}$ & $\begin{array}{c}0.545 * * * \\
(0.000)\end{array}$ & $\begin{array}{c}0.544 * * * \\
(0.000)\end{array}$ & $\begin{array}{c}0.193 * * * \\
(0.000)\end{array}$ & $\begin{array}{c}0.188 * * * \\
(0.000)\end{array}$ & $\begin{array}{c}0.200 * * * \\
(0.000)\end{array}$ & $\begin{array}{c}0.197 * * * \\
(0.000)\end{array}$ \\
\hline $\ln$ (Total Sales) & $\begin{array}{c}0.021^{* * *} \\
(0.000)\end{array}$ & $\begin{array}{c}-0.002 * * \\
(0.034)\end{array}$ & $\begin{array}{c}-0.002 * * \\
(0.012)\end{array}$ & $\begin{array}{l}0.001^{*} \\
(0.094)\end{array}$ & $\begin{array}{c}-0.019 * * * \\
(0.000)\end{array}$ & $\begin{array}{c}-0.032 * * * \\
(0.000)\end{array}$ & $\begin{array}{c}-0.019 * * * \\
(0.000)\end{array}$ & $\begin{array}{c}-0.019 * * * \\
(0.000)\end{array}$ \\
\hline Firm Age & $\begin{array}{l}-0.005 \\
(0.501)\end{array}$ & $\begin{array}{l}0.001 \\
(0.768)\end{array}$ & $\begin{array}{c}-0.003 * * * \\
(0.004)\end{array}$ & $\begin{array}{l}0.001 \\
(0.349)\end{array}$ & $\begin{array}{c}-0.020^{* * *} \\
(0.000)\end{array}$ & $\begin{array}{c}-0.065^{* * *} \\
(0.000)\end{array}$ & $\begin{array}{c}-0.016^{* * *} \\
(0.000)\end{array}$ & $\begin{array}{c}-0.016^{* * *} \\
(0.000)\end{array}$ \\
\hline $\begin{array}{l}\text { Operating Return on } \\
\text { Assets }\end{array}$ & $\begin{array}{c}-0.576^{* * *} \\
(0.000)\end{array}$ & & & & $\begin{array}{c}-0.291 * * * \\
(0.000)\end{array}$ & $\begin{array}{c}-0.620 * * * \\
(0.000)\end{array}$ & $\begin{array}{c}-0.236^{* * *} \\
(0.000)\end{array}$ & $\begin{array}{c}-0.216^{* * *} \\
(0.000)\end{array}$ \\
\hline Surplus Cash & & $\begin{array}{l}0.021 * * \\
(0.013)\end{array}$ & $\begin{array}{c}0.124 * * * \\
(0.000)\end{array}$ & $\begin{array}{l}-0.011 \\
(0.248)\end{array}$ & & & & \\
\hline Tobin's Q & $\begin{array}{c}-0.022^{* * *} \\
(0.000)\end{array}$ & $\begin{array}{l}0.003 * * * \\
(0.001)\end{array}$ & $\begin{array}{l}-0.000 \\
(0.714)\end{array}$ & $\begin{array}{c}0.001 * * * \\
(0.009)\end{array}$ & $\begin{array}{c}0.008^{* * *} \\
(0.007)\end{array}$ & $\begin{array}{c}0.057 * * * \\
(0.000)\end{array}$ & $\begin{array}{l}0.005^{*} \\
(0.072)\end{array}$ & $\begin{array}{c}0.004 \\
(0.126)\end{array}$ \\
\hline R\&D/Total Assets & $\begin{array}{c}-0.358^{* * *} \\
(0.000)\end{array}$ & $\begin{array}{l}-0.039^{*} \\
(0.078)\end{array}$ & & $\begin{array}{c}0.004 \\
(0.783)\end{array}$ & $\begin{array}{c}0.476^{* * *} \\
(0.000)\end{array}$ & $\begin{array}{c}1.053^{* * * *} \\
(0.000)\end{array}$ & $\begin{array}{c}0.414 * * * \\
(0.000)\end{array}$ & $\begin{array}{c}0.387^{* * *} \\
(0.000)\end{array}$ \\
\hline Adv./Total Assets & & $\begin{array}{c}0.016 \\
(0.656)\end{array}$ & $\begin{array}{l}-0.020 \\
(0.582)\end{array}$ & & $\begin{array}{c}0.154 \\
(0.172)\end{array}$ & $\begin{array}{l}-0.116 \\
(0.756)\end{array}$ & $\begin{array}{l}0.177^{*} \\
(0.098)\end{array}$ & $\begin{array}{l}0.182 * \\
(0.082)\end{array}$ \\
\hline
\end{tabular}


Table 16 Continued

\begin{tabular}{|c|c|c|c|c|c|c|c|c|}
\hline \multicolumn{9}{|c|}{ irm Characteristics (Continued) } \\
\hline \multicolumn{3}{|c|}{ CAPEXP } & $\begin{array}{l}-0.005 \\
(0.746)\end{array}$ & $\begin{array}{l}0.017^{*} \\
(0.082)\end{array}$ & $\begin{array}{c}0.289^{* * *} \\
(0.000)\end{array}$ & $\begin{array}{c}0.550^{* *} \\
(0.010)\end{array}$ & $\begin{array}{c}0.246^{* * *} \\
(0.000)\end{array}$ & $\begin{array}{c}0.228^{* * * *} \\
(0.000)\end{array}$ \\
\hline Leverage & & $\begin{array}{l}-0.012 \\
(0.104)\end{array}$ & $\begin{array}{l}0.009 * * \\
(0.047)\end{array}$ & $\begin{array}{l}-0.006^{*} \\
(0.059)\end{array}$ & $\begin{array}{c}0.071 * * * \\
(0.001)\end{array}$ & $\begin{array}{c}0.061 \\
(0.420)\end{array}$ & $\begin{array}{c}0.077^{* * *} \\
(0.000)\end{array}$ & $\begin{array}{c}0.076^{* * *} \\
(0.000)\end{array}$ \\
\hline Industry Homogeneity & & & $\begin{array}{c}0.005 \\
(0.677)\end{array}$ & & & & & \\
\hline Capital Intensity & $\begin{array}{c}0.116^{* * *} \\
(0.000)\end{array}$ & & & & & & & \\
\hline Depr./Total Assets & $\begin{array}{l}-0.073 \\
(0.692)\end{array}$ & & & & & & & \\
\hline $\begin{array}{l}\text { Pay Directors Equity } \\
\text { Based Compensation }\end{array}$ & $\begin{array}{l}0.012^{*} \\
(0.096)\end{array}$ & $\begin{array}{l}-0.001 \\
(0.752)\end{array}$ & $\begin{array}{c}0.002 \\
(0.140)\end{array}$ & $\begin{array}{l}0.002 * \\
(0.100)\end{array}$ & $\begin{array}{c}0.009 \\
(0.196)\end{array}$ & $\begin{array}{c}0.003 \\
(0.909)\end{array}$ & $\begin{array}{c}0.008 \\
(0.212)\end{array}$ & $\begin{array}{c}0.008 \\
(0.191)\end{array}$ \\
\hline $\begin{array}{l}\text { Activist Institutional } \\
\text { Holding }(\%)\end{array}$ & $\begin{array}{l}-0.242 \\
(0.348)\end{array}$ & $\begin{array}{l}-0.059 \\
(0.346)\end{array}$ & $\begin{array}{c}0.058 \\
(0.161)\end{array}$ & $\begin{array}{l}-0.013 \\
(0.739)\end{array}$ & $\begin{array}{l}-0.130 \\
(0.527)\end{array}$ & $\begin{array}{l}1.554 * * \\
(0.025)\end{array}$ & $\begin{array}{l}-0.283 \\
(0.149)\end{array}$ & $\begin{array}{l}-0.294 \\
(0.125)\end{array}$ \\
\hline $\begin{array}{l}\text { CEO Cash } \\
\text { Compensation }\end{array}$ & $\begin{array}{c}0.016^{* *} \\
(0.027)\end{array}$ & $\begin{array}{l}-0.003 \\
(0.129)\end{array}$ & $\begin{array}{c}0.006^{* * *} \\
(0.004)\end{array}$ & $\begin{array}{c}0.002 * * \\
(0.032)\end{array}$ & $\begin{array}{c}-0.014 * * \\
(0.045)\end{array}$ & $\begin{array}{c}-0.100^{* * *} \\
(0.000)\end{array}$ & $\begin{array}{l}-0.008 \\
(0.179)\end{array}$ & $\begin{array}{l}-0.006 \\
(0.268)\end{array}$ \\
\hline $\begin{array}{l}\text { CEO Compensation } \\
\text { Delta }\end{array}$ & $\begin{array}{l}-0.007 \\
(0.110)\end{array}$ & $\begin{array}{l}-0.001 \\
(0.324)\end{array}$ & $\begin{array}{l}-0.001 \\
(0.221)\end{array}$ & $\begin{array}{c}0.001 \\
(0.209)\end{array}$ & $\begin{array}{c}0.002 \\
(0.563)\end{array}$ & $\begin{array}{c}0.021 \\
(0.199)\end{array}$ & $\begin{array}{c}0.000 \\
(0.987)\end{array}$ & $\begin{array}{l}-0.000 \\
(0.906)\end{array}$ \\
\hline $\begin{array}{l}\text { CEO Compensation } \\
\text { Vega }\end{array}$ & $\begin{array}{l}-0.018^{*} \\
(0.059)\end{array}$ & $\begin{array}{l}-0.001 \\
(0.788)\end{array}$ & $\begin{array}{l}0.004 * * \\
(0.028)\end{array}$ & $\begin{array}{l}-0.002 \\
(0.264)\end{array}$ & $\begin{array}{l}-0.011 \\
(0.153)\end{array}$ & $\begin{array}{c}-0.074 * * \\
(0.020)\end{array}$ & $\begin{array}{l}-0.010 \\
(0.148)\end{array}$ & $\begin{array}{l}-0.009 \\
(0.185)\end{array}$ \\
\hline Herfindhal Index & $\begin{array}{c}0.353 * * * \\
(0.004)\end{array}$ & $\begin{array}{l}-0.037 \\
(0.319)\end{array}$ & $\begin{array}{l}-0.011 \\
(0.636)\end{array}$ & $\begin{array}{c}0.027 \\
(0.205)\end{array}$ & $\begin{array}{c}0.356^{* * *} \\
(0.001)\end{array}$ & $\begin{array}{c}0.440 \\
(0.306)\end{array}$ & $\begin{array}{c}0.308 * * * \\
(0.002)\end{array}$ & $\begin{array}{c}0.291 * * * \\
(0.003)\end{array}$ \\
\hline \multicolumn{9}{|l|}{$\underline{\text { CEO Characteristics }}$} \\
\hline $\operatorname{Ln}(\mathrm{CEO}$ Tenure +1$)$ & $\begin{array}{c}0.003 \\
(0.578)\end{array}$ & $\begin{array}{c}-0.004 * * \\
(0.016)\end{array}$ & $\begin{array}{l}-0.000 \\
(0.908)\end{array}$ & $\begin{array}{l}-0.001 \\
(0.104)\end{array}$ & $\begin{array}{c}0.000 \\
(0.936)\end{array}$ & $\begin{array}{l}-0.003 \\
(0.856)\end{array}$ & $\begin{array}{l}-0.002 \\
(0.649)\end{array}$ & $\begin{array}{l}-0.002 \\
(0.557)\end{array}$ \\
\hline CEO Age & $\begin{array}{c}-0.067 * * \\
(0.031)\end{array}$ & $\begin{array}{l}-0.016^{*} \\
(0.059)\end{array}$ & $\begin{array}{c}-0.015^{* *} \\
(0.024)\end{array}$ & $\begin{array}{l}-0.002 \\
(0.683)\end{array}$ & $\begin{array}{l}-0.047^{*} \\
(0.065)\end{array}$ & $\begin{array}{c}0.064 \\
(0.457)\end{array}$ & $\begin{array}{c}-0.046^{* *} \\
(0.047)\end{array}$ & $\begin{array}{c}-0.046^{* *} \\
(0.039)\end{array}$ \\
\hline $\operatorname{MBA}(0 / 1)$ & $\begin{array}{l}0.014^{*} \\
(0.068)\end{array}$ & $\begin{array}{l}-0.002 \\
(0.262)\end{array}$ & $\begin{array}{c}0.002 \\
(0.330)\end{array}$ & $\begin{array}{l}-0.001 \\
(0.420)\end{array}$ & $\begin{array}{l}-0.009^{*} \\
(0.091)\end{array}$ & $\begin{array}{c}0.008 \\
(0.691)\end{array}$ & $\begin{array}{l}-0.009^{*} \\
(0.070)\end{array}$ & $\begin{array}{l}-0.009^{*} \\
(0.056)\end{array}$ \\
\hline Founder $(0 / 1)$ & $\begin{array}{c}0.015 \\
(0.298)\end{array}$ & $\begin{array}{l}-0.004 \\
(0.224)\end{array}$ & $\begin{array}{l}-0.005^{*} \\
(0.072)\end{array}$ & $\begin{array}{l}-0.002 \\
(0.301)\end{array}$ & $\begin{array}{c}0.022^{* *} \\
(0.041)\end{array}$ & $\begin{array}{c}0.047 \\
(0.177)\end{array}$ & $\begin{array}{c}0.020^{* *} \\
(0.041)\end{array}$ & $\begin{array}{l}0.019 * * \\
(0.039)\end{array}$ \\
\hline \# Functional Areas & $\begin{array}{l}-0.002 \\
(0.661)\end{array}$ & $\begin{array}{l}-0.001 \\
(0.421)\end{array}$ & $\begin{array}{c}0.001 \\
(0.467)\end{array}$ & $\begin{array}{l}-0.001 \\
(0.377)\end{array}$ & $\begin{array}{c}0.003 \\
(0.300)\end{array}$ & $\begin{array}{c}0.007 \\
(0.489)\end{array}$ & $\begin{array}{c}0.002 \\
(0.412)\end{array}$ & $\begin{array}{c}0.001 \\
(0.571)\end{array}$ \\
\hline $\begin{array}{l}\text { Has Finance } \\
\text { Background }(0 / 1)\end{array}$ & $\begin{array}{c}0.009 \\
(0.299)\end{array}$ & $\begin{array}{l}-0.004 \\
(0.106)\end{array}$ & $\begin{array}{c}-0.005^{* * *} \\
(0.001)\end{array}$ & $\begin{array}{l}-0.001 \\
(0.420)\end{array}$ & $\begin{array}{c}0.001 \\
(0.898)\end{array}$ & $\begin{array}{l}-0.003 \\
(0.907)\end{array}$ & $\begin{array}{c}0.001 \\
(0.848)\end{array}$ & $\begin{array}{c}0.001 \\
(0.882)\end{array}$ \\
\hline Constant & $\begin{array}{l}0.233^{*} \\
(0.092)\end{array}$ & $\begin{array}{c}0.139 * * * \\
(0.000)\end{array}$ & $\begin{array}{c}0.086^{* * *} \\
(0.002)\end{array}$ & $\begin{array}{c}0.004 \\
(0.814)\end{array}$ & $\begin{array}{c}0.597 * * * \\
(0.000)\end{array}$ & $\begin{array}{c}0.914^{* *} \\
(0.012)\end{array}$ & $\begin{array}{c}0.592 * * * \\
(0.000)\end{array}$ & $\begin{array}{c}0.587^{* * *} \\
(0.000)\end{array}$ \\
\hline Year Dummies & Yes & Yes & Yes & Yes & Yes & Yes & Yes & Yes \\
\hline Industry Dummies & Yes & Yes & Yes & Yes & Yes & Yes & Yes & Yes \\
\hline Observations & 4826 & 5029 & 4914 & 5074 & 4693 & 4693 & 4693 & 4693 \\
\hline R-squared & 0.572 & 0.521 & 0.767 & 0.635 & 0.636 & 0.450 & 0.656 & 0.654 \\
\hline Hansen's J-test (p-value) & 0.617 & 0.744 & 0.125 & 0.524 & 0.129 & 0.380 & 0.111 & 0.117 \\
\hline $\begin{array}{l}\text { First-stage } F \text {-stat for } \\
\text { Principal Comp. One }\end{array}$ & 99.93 & 110.23 & 45.53 & 82.57 & 94.71 & 84.22 & 96.33 & 96.57 \\
\hline
\end{tabular}

First-stage F-stat for Principal Comp. One * Industry Homogeneity 


\section{Table 17. The Number Employers and CEO Turnover Announcement Returns for Stockholders.}

This table presents the mean cumulative abnormal returns (CARs) for the announcement of CEO turnovers. Average CARS are presented for CEOs that have worked for one employer (\#Employers=1) and for CEOs that have worked for five employers (\#Employers>=5). I follow Parrino (1997) to classify a CEO turnover as forced or unforced. I exclude CEO turnovers that are results of CEO sudden death, merger and acquisitions and Spin-offs. I present results for two event windows: day -3 to day 1 and day -1 to day 1 . The CARs are based on the market model using value weighted market index. Statistical significances are based on Patell Z statistic. Insiders are CEOs who have worked in the firm before assuming the CEO title of the firm. Outsiders are CEOs did not work in the firm before assuming the CEO title of the firm. I indicate significance at the $1 \%, 5 \%$, and $10 \%$ levels with ***,**, and *, respectively.

\begin{tabular}{|c|c|c|c|c|c|c|c|c|c|c|}
\hline \multirow[b]{3}{*}{ All Turnovers } & \multirow[b]{2}{*}{ Event Window } & \multirow[b]{2}{*}{ Obs. } & \multirow[b]{2}{*}{ CAR (\%) } & \multirow[b]{2}{*}{ Positive (\%) } & \multicolumn{3}{|c|}{ Insiders } & \multicolumn{3}{|c|}{ Outsiders } \\
\hline & & & & & Obs. & CAR $(\%)$ & Positive (\%) & Obs. & CAR (\%) & Positive (\%) \\
\hline & & & & & & & & & & \\
\hline \multirow{2}{*}{ \# Employers =1 } & $t=-3$ to $t=+1$ & 175 & $-0.15 \%$ & $48.00 \%$ & & & & & & \\
\hline & $\mathrm{t}=-1$ to $\mathrm{t}=+1$ & 175 & $-0.01 \%$ & $49.14 \%$ & & & & & & \\
\hline \multirow[t]{2}{*}{ \# Employers >4 } & $\mathrm{t}=-3$ to $\mathrm{t}=+1$ & 185 & $1.57 \% * * *$ & $54.59 \% *$ & 80 & $0.91 \% *$ & $58.75 \% *$ & 105 & $2.07 \% * * *$ & $59.05 \% * *$ \\
\hline & $t=-1$ to $t=+1$ & 185 & $1.13 \% * * *$ & $54.05 \% *$ & 80 & $1.02 \% * *$ & $55.00 \%$ & 105 & $1.21 \% * *$ & $56.19 \% *$ \\
\hline \multicolumn{11}{|l|}{ Forced Turnovers } \\
\hline \multirow[t]{2}{*}{ \# Employers =1 } & $t=-3$ to $t=+1$ & 11 & $-6.86 \% * * *$ & $27.27 \% *$ & & & & & & \\
\hline & $\mathrm{t}=-1$ to $\mathrm{t}=+1$ & 11 & $-2.81 \% *$ & $27.27 \% *$ & & & & & & \\
\hline \multirow[t]{2}{*}{ \# Employers $>4$} & $\mathrm{t}=-3$ to $\mathrm{t}=+1$ & 36 & $1.17 \%$ & $59.46 \% *$ & 7 & $0.03 \%$ & $42.86 \%$ & 29 & $2.55 \% * *$ & $65.52 \% * *$ \\
\hline & $t=-1$ to $t=+1$ & 36 & $1.18 \% *$ & $56.76 \% *$ & 7 & $2.22 \% * *$ & $71.43 \% *$ & 29 & $1.31 \%$ & $55.17 \%$ \\
\hline \multicolumn{11}{|l|}{ Normal Succession } \\
\hline \multirow[t]{2}{*}{ \# Employers =1 } & $\mathrm{t}=-3$ to $\mathrm{t}=+1$ & 147 & $0.20 \%$ & $49.66 \%$ & & & & & & \\
\hline & $t=-1$ to $t=+1$ & 147 & $0.03 \%$ & $49.66 \%$ & & & & & & \\
\hline \multirow[t]{2}{*}{ \# Employers $>4$} & $\mathrm{t}=-3$ to $\mathrm{t}=+1$ & 122 & $1.46 \% * *$ & $51.64 \%$ & 63 & $1.22 \% *$ & $52.38 \%$ & 59 & $1.71 \% * *$ & $61.02 \% *$ \\
\hline & $\mathrm{t}=-1$ to $\mathrm{t}=+1$ & 122 & $1.15 \% * * *$ & $53.28 \%$ & 63 & $0.97 \%$ * & $55.56 \%$ & 59 & $1.35 \% * *$ & $54.24 \%$ \\
\hline \multicolumn{11}{|c|}{ Prior one-year industry-adjusted stock return is positive } \\
\hline \multirow[t]{2}{*}{ \# Employers $=1$} & $\mathrm{t}=-3$ to $\mathrm{t}=+1$ & 90 & $0.56 \%$ & $54.44 \%$ & & & & & & \\
\hline & $t=-1$ to $t=+1$ & 90 & $0.13 \%$ & $50.00 \%$ & & & & & & \\
\hline \multirow[t]{2}{*}{ \# Employers $>4$} & $t=-3$ to $t=+1$ & 75 & $0.50 \%$ & $45.33 \%$ & 40 & $0.57 \%$ & $42.50 \%$ & 35 & $0.42 \%$ & $48.57 \%$ \\
\hline & $\mathrm{t}=-1$ to $\mathrm{t}=+1$ & 75 & $-0.09 \%$ & $41.33 \% *$ & 40 & $-0.02 \%$ & $47.50 \%$ & 35 & $-0.18 \%$ & $34.29^{* *}$ \\
\hline \multicolumn{11}{|c|}{ Prior one-year industry-adjusted stock return is negative } \\
\hline \multirow{2}{*}{ \# Employers $=1$} & $\mathrm{t}=-3$ to $\mathrm{t}=+1$ & 80 & $-0.78 \% * *$ & $41.25 \%$ & & & & & & \\
\hline & $t=-1$ to $t=+1$ & 80 & $-0.13 \%$ & $48 \%$ & & & & & & \\
\hline \multirow{2}{*}{ \# Employers $>4$} & $t=-3$ to $t=+1$ & 106 & $2.23 \% * * *$ & $60.38 \% * * *$ & 38 & $1.59 \% * *$ & $55 \%$ & 68 & $2.59 \% * * *$ & $63.24 \% * * *$ \\
\hline & $t=-1$ to $t=+1$ & 106 & $1.94 \% * * *$ & $63.21 \% * * *$ & 38 & $1.82 \% * * *$ & $63.16 \% * *$ & 68 & $2.01 \% * * *$ & $63.24 \% * * *$ \\
\hline
\end{tabular}




\section{Table 18. CEO Employment History and the Event Study CARs}

This table presents WLS results for the cross-sectional regression of CARs on CEO employment history and other CEO characteristics. The weights in WLS are the inverse of the standard deviation of the market model residuals. The dependent variable is the CAR from the event window $[-3,1]$. Refer to Table 1 and Appendix A for variable definitions. The CARs are based on the market model using value weighted market index. I follow Parrino (1997) to classify a CEO turnover as forced or unforced. I exclude CEO turnovers that are results of CEO sudden death, merger and acquisitions and Spin-offs. Insiders are CEOs who have worked in the firm before assuming the CEO title of the firm. I report $p$-values based on robust standard errors in parenthesis. ${ }^{* *},{ }^{* *}$, and $*$ indicate significance at the 1,5 , and $10 \%$ levels, respectively.

\begin{tabular}{lcccc}
\hline & & Insider & Insider \\
& All Turnovers & Successions & All Turnovers & Successions \\
\cline { 2 - 5 } \# Employers & 0.002 & $0.003^{*}$ & & \\
\#Employers Quartiles & $(0.122)$ & $(0.066)$ & & \\
& & & $0.004^{* *}$ & $0.004^{*}$ \\
Ln(Total Sales) & & & $(0.043)$ & $(0.089)$ \\
& -0.001 & -0.002 & -0.001 & -0.002 \\
Lag(Operating Return on Assets) & $(0.361)$ & $(0.267)$ & $(0.437)$ & $(0.281)$ \\
& $-0.060^{* *}$ & -0.012 & $-0.059 * *$ & -0.013 \\
Ln(CEO Age) & $(0.035)$ & $(0.700)$ & $(0.035)$ & $(0.672)$ \\
& 0.004 & 0.019 & 0.005 & 0.020 \\
MBA (0/1) & $(0.800)$ & $(0.267)$ & $(0.772)$ & $(0.255)$ \\
\# Functional Areas & 0.002 & 0.001 & 0.002 & 0.001 \\
& $(0.613)$ & $(0.862)$ & $(0.693)$ & $(0.899)$ \\
Has Finance Background (0/1) & -0.001 & -0.000 & -0.002 & -0.000 \\
& $(0.505)$ & $(0.951)$ & $(0.462)$ & $(0.967)$ \\
Forced Turnover (0/1) & -0.003 & -0.008 & -0.003 & $-0.008^{*}$ \\
Constant & $(0.531)$ & $(0.109)$ & $(0.512)$ & $(0.100)$ \\
& -0.003 & $-0.030^{* * *}$ & -0.004 & $-0.029^{* * *}$ \\
Year Dummies & $(0.618)$ & $(0.002)$ & $(0.591)$ & $(0.002)$ \\
Industry Dummies & -0.183 & -0.078 & -0.189 & -0.080 \\
Observations & $(0.219)$ & $(0.498)$ & $(0.203)$ & $(0.487)$ \\
R-squared & Yes & Yes & Yes & Yes \\
\hline & Yes & Yes & Yes & Yes \\
& 865 & 633 & 865 & 633 \\
& 0.108 & 0.136 & 0.110 & 0.136 \\
\hline
\end{tabular}




\section{Table 19. The Number of Employers and Long-run Performance}

The table presents change in industry-median-adjusted accounting/stock performance following CEO turnovers. Panel A reports comparison on long-run performance for three years following CEO turnovers. Panel B reports comparison on variances of post-turnover performance for CEOs that have worked for different numbers of employers. For variable definitions, refer to Appendix A and Table 1. I report changes in performance for year -1 to +1 , year -1 to +2 , year 1 to +3 . Year 0 is the year of CEO turnover. \# Employers is the number of employer the CEO has worked for. Survival ratio is the number of CEOs who remain as CEOs for the year of interest divided by the total number of CEOs in that group at year 1. Year 1 is one year after the year of CEO turn over. Statistical significances are based on $p$-values of t-tests for differences in means and of signed rank test for differences in medians. I indicate significance at the $1 \%, 5 \%$, and $10 \%$ levels with $* * *, * *$, and $*$, respectively.

Panel A. \#Employers and Long-run Industry-median Adjusted Changes in Performance

\begin{tabular}{|c|c|c|c|c|c|c|c|c|c|}
\hline & \multicolumn{3}{|c|}{ Number of Employers=1 } & \multicolumn{3}{|c|}{ Number of Employers $>=5$} & \multicolumn{3}{|c|}{ Differences } \\
\hline & Obs. & Mean & Median & Obs. & Mean & Median & Mean & Median & $\begin{array}{l}\text { Variance } \\
\text { (p-value) }\end{array}$ \\
\hline & & \multicolumn{8}{|c|}{ Year $t=-1$ to $t=1$} \\
\hline OROA & 127 & -0.003 & -0.001 & 164 & 0.005 & 0.000 & 0.007 & 0.001 & 0.000 \\
\hline Annual Stock Return & 127 & -0.035 & -0.041 & 160 & 0.047 & $0.089^{*}$ & $0.082 *$ & $0.129^{* *}$ & 0.000 \\
\hline Return on Equity & 127 & 0.006 & -0.001 & 164 & 0.029 & 0.003 & 0.023 & 0.004 & 0.000 \\
\hline Tobin's Q & 127 & 0.004 & $-0.160 *$ & 160 & -0.097 & -0.121 & -0.102 & 0.039 & 0.000 \\
\hline \multirow[t]{2}{*}{ Sales Growth } & 127 & -0.040 & $-0.022 *$ & 163 & 0.006 & 0.001 & $0.046^{*}$ & 0.023 & 0.043 \\
\hline & & \multicolumn{8}{|c|}{ Year $t=-1$ to $t=2$} \\
\hline OROA & 126 & -0.002 & 0.001 & 148 & 0.002 & -0.005 & 0.003 & -0.006 & 0.000 \\
\hline Annual Stock Return & 126 & -0.007 & 0.024 & 144 & $0.122^{*}$ & $0.062 *$ & $0.129^{*}$ & $0.038^{*}$ & 0.000 \\
\hline Return on Equity & 126 & -0.006 & -0.004 & 148 & 0.037 & -0.002 & 0.043 & 0.001 & 0.000 \\
\hline Tobin's Q & 126 & $-0.201 *$ & $-0.090^{*}$ & 144 & -0.257 & -0.120 & -0.056 & -0.030 & 0.000 \\
\hline \multirow[t]{2}{*}{ Sales Growth } & 126 & $-0.044 *$ & -0.011 & 147 & 0.003 & 0.020 & 0.047 & $0.031^{*}$ & 0.190 \\
\hline & & \multicolumn{8}{|c|}{ Year $t=-1$ to $t=3$} \\
\hline OROA & 124 & -0.002 & 0.000 & 130 & 0.004 & -0.001 & 0.006 & -0.001 & 0.000 \\
\hline Annual Stock Return & 124 & 0.037 & 0.030 & 126 & $0.095^{*}$ & $0.093^{*}$ & 0.058 & 0.063 & 0.000 \\
\hline Return on Equity & 124 & 0.001 & -0.005 & 130 & 0.029 & 0.007 & 0.028 & 0.012 & 0.000 \\
\hline Tobin's Q & 124 & -0.067 & -0.105 & 126 & -0.142 & -0.279 & -0.075 & -0.174 & 0.000 \\
\hline Sales Growth & 124 & -0.035 & -0.024 & 129 & 0.023 & 0.037 & $0.058 *$ & $0.061^{* *}$ & 0.025 \\
\hline
\end{tabular}


Table 19 Continued.

Panel B. \#Employers and Variance in Post-turnover Industry Median Adjusted Changes in Performance

\begin{tabular}{|c|c|c|c|c|c|c|c|c|c|c|c|c|c|c|}
\hline & & & & \multirow{2}{*}{\multicolumn{3}{|c|}{ \# Employers $>=5$}} & \multicolumn{4}{|c|}{ All Categories } & \multicolumn{4}{|c|}{ \#Employers $=1$ Vs. \#Employers $>=5$} \\
\hline & \multicolumn{3}{|c|}{ \# Employers=1 } & & & & \multicolumn{2}{|c|}{$\begin{array}{c}\text { Differences } \\
\text { in Means }\end{array}$} & \multicolumn{2}{|c|}{$\begin{array}{c}\text { Levene's Test for } \\
\text { Homogeneity of } \\
\text { Variance }\end{array}$} & \multicolumn{2}{|c|}{$\begin{array}{c}\text { Differences } \\
\text { in Means }\end{array}$} & \multicolumn{2}{|c|}{$\begin{array}{c}\text { Levene's Test for } \\
\text { Homogeneity of } \\
\text { Variance }\end{array}$} \\
\hline & Obs. & Mean & Std. & Obs. & Mean & Std. & $F$-stat & $p$-value & $F$-stat & $p$-value & $F$-stat & $p$-value & $F$-stat & $p$-value \\
\hline OROA & 1125 & -0.002 & 0.081 & 993 & 0.010 & 0.123 & 4.29 & 0.000 & 29.34 & 0.000 & 6.20 & 0.013 & 72.35 & 0.000 \\
\hline Annual Stock Return & 1079 & -0.026 & 0.517 & 924 & 0.091 & 0.665 & 10.28 & 0.000 & 14.96 & 0.000 & 19.68 & 0.000 & 25.61 & 0.000 \\
\hline Return on Equity & 1125 & 0.013 & 0.244 & 986 & 0.022 & 0.426 & 2.45 & 0.061 & 19.29 & 0.000 & 0.36 & 0.547 & 53.17 & 0.000 \\
\hline Tobin's Q & 1088 & 0.126 & 3.112 & 924 & -0.351 & 3.811 & 3.39 & 0.017 & 2.86 & 0.036 & 9.54 & 0.002 & 4.62 & 0.032 \\
\hline Sales Growth & 1098 & -0.034 & 0.266 & 967 & 0.002 & 0.335 & 2.59 & 0.051 & 19.38 & 0.000 & 7.54 & 0.006 & 16.29 & 0.000 \\
\hline
\end{tabular}




\section{Table 20. The Number Employers and CEO Turnover Announcement Returns for Bondholders}

This table presents the mean abnormal announcement bond returns for the month of CEO turnovers. I compute the abnormal bond returns as the actual bond returns for the month of CEO turnover minus the expected bond returns based the average of bond returns from month -4 to month -2 . Abnormal bond return premium is the actual bond return premium for the month of CEO turnover minus the expected bond return premium based on the average of bond returns from month -4 to month -2 . Bond return premium is the raw bond return subtracts the maturitymatched return on Treasury bonds. Abnormal Yield to Maturity is the actual YTM in the month of CEO turnover minus the expected YTM which is computed as the average of YTM from month -4 to month -2 . Abnormal Bond Spread is the actual bond spread minus the expected bond spread, which is the average of bond spread form month 4 to month -2 . Bond spread is computed as the bond's YTM subtracts the maturity-matched yield on Treasury bonds. I indicate significance at the $1 \%, 5 \%$, and $10 \%$ levels with $* * *, * *$, and $*$, respectively.

\begin{tabular}{|c|c|c|c|c|c|c|c|c|c|}
\hline & \multicolumn{2}{|c|}{ \# Emp. $=1$} & \multicolumn{2}{|c|}{ \# Emp. $=2$} & \multicolumn{2}{|c|}{$\#$ Emp. $=3,4$} & \multicolumn{2}{|c|}{$\#$ Emp. $>=5$} & \multirow{2}{*}{$\begin{array}{c}\text { Differences } \\
\text { in Means } \\
\end{array}$} \\
\hline & Obs & Mean & Obs & Mean & Obs & Mean & Obs & Mean & \\
\hline Abnormal YTM & 34 & $-0.74 \% *$ & 32 & $-0.02 \%$ & 31 & $-0.15 \%$ & 24 & $0.18 \%$ & $0.66 \%$ \\
\hline Abnormal Bond Spread & 34 & $-0.36 \%$ & 32 & $0.15 \%$ & 31 & $0.03 \%$ & 24 & $0.26 \%$ & $0.62 \%$ \\
\hline $\begin{array}{l}\text { Abnormal Bond Return } \\
\text { Abnormal Bond Return }\end{array}$ & 34 & $0.21 \%$ & 32 & $-0.09 \%$ & 31 & $1.63 \%$ & 24 & $-0.41 \%$ & $-0.62 \%$ \\
\hline Premium & 34 & $0.59 \%$ & 32 & $0.08 \%$ & 31 & $1.81 \%$ & 24 & $-0.33 \%$ & $-0.92 \%$ \\
\hline
\end{tabular}




\section{Table 21. Summary Statistics for the Cost of Debt}

This table presents summary statistics for the two costs of debt variables for firms with bond spreads and rating data available. I compute Bond spread as the bond's YTM subtracts the maturity-matched yield on Treasury bonds. The dependent variable is the S\&P credit rating number. Rating of AAA has a value of 1 for the rating number variable and CCC- has a value of 17 for the rating number variable. I present the distribution of firms in each bond rating in Panel B. Appendix A contains information on how credit rating letters are converted to rating numbers. The detailed computation for bond spread is in Section 7.2.

Panel A. Summary Statistics for Bond Spread and Credit Rating

\begin{tabular}{lcccccc}
\hline Variables & Obs. & Mean & Median & Max. & Min. & Std. \\
\hline S\&P Credit Rating (Whole Sample) & 2,866 & 9.006 & 9 & 16 & 1 & 3.035 \\
S\&P Credit Rating (Sample for & & & & & & \\
Regression) & 1,998 & 8.596 & 9 & 16 & 1 & 3.147 \\
Bond Spread (Whole Sample) & 1,292 & 0.023 & 0.016 & 0.112 & -0.002 & 0.019 \\
Bond Spread (Sample for Regression) & 718 & 0.022 & 0.015 & 0.112 & -0.002 & 0.020 \\
\hline
\end{tabular}

Panel B. The distribution of observations in Credit Rating Categories

\begin{tabular}{ccccc}
\hline Bond Rating & $\begin{array}{c}\text { Bond } \\
\text { Rating } \\
\text { Number }\end{array}$ & Obs. & \% of Obs. & Cumulative \% \\
\hline AAA & 1 & 42 & $1.47 \%$ & $1.47 \%$ \\
AA+ & 2 & 12 & $0.42 \%$ & $1.88 \%$ \\
AA & 3 & 70 & $2.44 \%$ & $4.33 \%$ \\
AA- & 4 & 77 & $2.69 \%$ & $7.01 \%$ \\
A+ & 5 & 160 & $5.58 \%$ & $12.60 \%$ \\
A & 6 & 254 & $8.86 \%$ & $21.46 \%$ \\
A- & 7 & 255 & $8.90 \%$ & $30.36 \%$ \\
BBB+ & 8 & 291 & $10.15 \%$ & $40.51 \%$ \\
BBB & 9 & 474 & $16.54 \%$ & $57.05 \%$ \\
BBB- & 10 & 342 & $11.93 \%$ & $68.98 \%$ \\
BB + & 11 & 223 & $7.78 \%$ & $76.76 \%$ \\
BB & 12 & 256 & $8.93 \%$ & $85.69 \%$ \\
BB- & 13 & 238 & $8.30 \%$ & $94.00 \%$ \\
B+ & 14 & 113 & $3.94 \%$ & $97.94 \%$ \\
B & 15 & 42 & $1.47 \%$ & $99.41 \%$ \\
B- & 16 & 17 & $0.59 \%$ & $100.00 \%$ \\
Total & & 2,866 & $100.00 \%$ & \\
\hline
\end{tabular}




\section{Table 22. CEO Employment History and the Bond Spread}

This table presents IV/2SLS results for a firm's bond spread on a sample of 718 firm years. The dependent variable is the bond spread, which is measured as the bond's YTM subtracts the maturity-matched yield on Treasury bonds. The detailed computation for bond spread is in Section 7.2. Refer to Table 1 and Appendix A for variable definitions. Instrumental variables are the unemployment rate for the year when the CEO started his first full-time job, non-business career dummy that equals one if the CEO had academic or government jobs, and the number of years the CEO has worked in his current firm's industry. Pre-turnover bond spread is the firm's bond spread in the year before the CEO turnover year. I report p-values of Hansen's J-test and first-stage $F$-stat at the bottom of the table. The values of the five CEO employment history proxies in the IV/2SLS estimations are predicted values. The predicted signs for the CEO employment history proxies are presented in parenthesis at the beginning of each row. I report $p$-values based on robust standard errors clustered at the firm level in parenthesis. ***, **, and * indicate significance at the 1,5 , and $10 \%$ levels, respectively.

\begin{tabular}{|c|c|c|c|c|c|c|}
\hline \multicolumn{7}{|c|}{ Panel A: Whole Sample (718 Obs.) } \\
\hline & & $(1)$ & $(2)$ & (3) & $(4)$ & $(5)$ \\
\hline \multicolumn{7}{|l|}{ CEO Employment History Variables } \\
\hline \# Employers & $(+)$ & $\begin{array}{l}0.002 * \\
(0.098)\end{array}$ & & & & \\
\hline \# Employer Changes per year & $(+)$ & & $\begin{array}{c}0.049 \\
(0.141)\end{array}$ & & & \\
\hline Employer Change Recency & $(+)$ & & & $\begin{array}{c}0.003 \\
(0.134)\end{array}$ & & \\
\hline Firm Experience Diversification & $(-)$ & & & & $\begin{array}{l}-0.007 \\
(0.182)\end{array}$ & \\
\hline $\begin{array}{l}\text { Industry Experience } \\
\text { Diversification }\end{array}$ & $(-)$ & & & & & $\begin{array}{l}-0.006 * \\
(0.092)\end{array}$ \\
\hline \multicolumn{7}{|l|}{ Firm Characteristics } \\
\hline Pre-turnover Spread & & $\begin{array}{c}0.202 * * * \\
(0.000)\end{array}$ & $\begin{array}{c}0.205^{* * *} \\
(0.000)\end{array}$ & $\begin{array}{c}0.196^{* * *} \\
(0.001)\end{array}$ & $\begin{array}{c}0.218 * * * \\
(0.000)\end{array}$ & $\begin{array}{c}0.223 * * * \\
(0.000)\end{array}$ \\
\hline Duration & & $\begin{array}{c}-0.002 * * * \\
(0.009)\end{array}$ & $\begin{array}{c}-0.002 * * * \\
(0.009)\end{array}$ & $\begin{array}{c}-0.002 * * * \\
(0.008)\end{array}$ & $\begin{array}{c}-0.002 * * * \\
(0.008)\end{array}$ & $\begin{array}{c}-0.002 * * \\
(0.011)\end{array}$ \\
\hline Convexity & & $\begin{array}{l}0.000 * * \\
(0.050)\end{array}$ & $\begin{array}{l}0.000 * * \\
(0.044)\end{array}$ & $\begin{array}{l}0.000 * * \\
(0.037)\end{array}$ & $\begin{array}{l}0.000 * * \\
(0.028)\end{array}$ & $\begin{array}{l}0.000 * * \\
(0.033)\end{array}$ \\
\hline $\ln$ (Total Sales) & & $\begin{array}{c}-0.004 * * * \\
(0.001)\end{array}$ & $\begin{array}{c}-0.004 * * * \\
(0.000)\end{array}$ & $\begin{array}{c}-0.004 * * * \\
(0.000)\end{array}$ & $\begin{array}{c}-0.004 * * * \\
(0.000)\end{array}$ & $\begin{array}{c}-0.004 * * * \\
(0.000)\end{array}$ \\
\hline Firm Age & & $\begin{array}{l}-0.001 \\
(0.515)\end{array}$ & $\begin{array}{l}-0.001 \\
(0.542)\end{array}$ & $\begin{array}{l}-0.001 \\
(0.568)\end{array}$ & $\begin{array}{l}-0.001 \\
(0.623)\end{array}$ & $\begin{array}{l}-0.001 \\
(0.586)\end{array}$ \\
\hline Annual Stock Return & & $\begin{array}{l}-0.002 \\
(0.397)\end{array}$ & $\begin{array}{l}-0.002 \\
(0.445)\end{array}$ & $\begin{array}{l}-0.002 \\
(0.338)\end{array}$ & $\begin{array}{l}-0.002 \\
(0.383)\end{array}$ & $\begin{array}{l}-0.002 \\
(0.414)\end{array}$ \\
\hline Tobin's Q & & $\begin{array}{c}-0.000 * * \\
(0.019)\end{array}$ & $\begin{array}{c}-0.000 * * \\
(0.021)\end{array}$ & $\begin{array}{c}-0.000 * * \\
(0.019)\end{array}$ & $\begin{array}{c}-0.000 * * \\
(0.016)\end{array}$ & $\begin{array}{c}-0.000 * * \\
(0.016)\end{array}$ \\
\hline Leverage & & $\begin{array}{c}0.018 * * * \\
(0.000)\end{array}$ & $\begin{array}{c}0.018 * * * \\
(0.000)\end{array}$ & $\begin{array}{c}0.018 * * * \\
(0.000)\end{array}$ & $\begin{array}{c}0.018 * * * \\
(0.000)\end{array}$ & $\begin{array}{c}0.018 * * * \\
(0.000)\end{array}$ \\
\hline Pay Directors Equity Based & & 0.000 & 0.000 & 0.000 & 0.000 & 0.000 \\
\hline Compensation $(0 / 1)$ & & $(0.971)$ & $(0.906)$ & $(0.973)$ & $(0.938)$ & $(0.927)$ \\
\hline Activist Institutional Holding (\%) & & $\begin{array}{c}0.046 \\
(0.646)\end{array}$ & $\begin{array}{c}0.039 \\
(0.693)\end{array}$ & $\begin{array}{c}0.036 \\
(0.724)\end{array}$ & $\begin{array}{c}0.039 \\
(0.694)\end{array}$ & $\begin{array}{c}0.025 \\
(0.799)\end{array}$ \\
\hline CEO Cash Compensation & & $\begin{array}{c}0.009 * * * \\
(0.001)\end{array}$ & $\begin{array}{c}0.009 * * * \\
(0.001)\end{array}$ & $\begin{array}{c}0.009 * * * \\
(0.002)\end{array}$ & $\begin{array}{c}0.009 * * * \\
(0.002)\end{array}$ & $\begin{array}{c}0.008 * * * \\
(0.003)\end{array}$ \\
\hline CEO Compensation Delta & & $\begin{array}{r}0.002 \\
(0.254) \\
\end{array}$ & $\begin{array}{r}0.002 \\
(0.204) \\
\end{array}$ & $\begin{array}{r}0.001 \\
(0.413) \\
\end{array}$ & $\begin{array}{r}0.001 \\
(0.314) \\
\end{array}$ & $\begin{array}{r}0.001 \\
(0.309) \\
\end{array}$ \\
\hline
\end{tabular}


Table 22 Continued.

\begin{tabular}{lccccc}
\hline Firm Characteristics (Continued) & & & & & \\
CEO Compensation Vega & -0.005 & $-0.005^{*}$ & -0.004 & -0.004 & -0.004 \\
Herfindhal Index & $(0.110)$ & $(0.090)$ & $(0.156)$ & $(0.149)$ & $(0.131)$ \\
& 0.002 & 0.002 & -0.001 & 0.001 & 0.001 \\
CEO Characteristics & $(0.881)$ & $(0.891)$ & $(0.926)$ & $(0.954)$ & $(0.959)$ \\
Ln(CEO Tenure+1) & & & & & \\
& 0.002 & 0.002 & 0.002 & 0.003 & 0.003 \\
CEO Age & $(0.317)$ & $(0.308)$ & $(0.290)$ & $(0.242)$ & $(0.200)$ \\
& -0.012 & -0.003 & -0.012 & -0.010 & -0.009 \\
MBA (0/1) & $(0.223)$ & $(0.815)$ & $(0.218)$ & $(0.317)$ & $(0.354)$ \\
& 0.000 & 0.000 & 0.000 & 0.000 & 0.000 \\
Founder (0/1) & $(0.926)$ & $(0.971)$ & $(0.928)$ & $(0.924)$ & $(0.936)$ \\
& 0.002 & 0.002 & 0.002 & 0.002 & 0.002 \\
\# Functional Areas & $(0.513)$ & $(0.511)$ & $(0.630)$ & $(0.516)$ & $(0.555)$ \\
& -0.000 & -0.000 & 0.000 & -0.000 & -0.000 \\
Has Finance Background (0/1) & $(0.796)$ & $(0.825)$ & $(0.991)$ & $(0.999)$ & $(0.984)$ \\
& $0.004^{*}$ & $0.004^{*}$ & $0.004^{*}$ & $0.004^{*}$ & 0.004 \\
Constant & $(0.086)$ & $(0.078)$ & $(0.088)$ & $(0.082)$ & $(0.129)$ \\
& $0.078^{*}$ & 0.043 & $0.081^{*}$ & $0.081^{*}$ & $0.080^{*}$ \\
Year Dummies & $(0.070)$ & $(0.446)$ & $(0.055)$ & $(0.060)$ & $(0.060)$ \\
Industry Dummies & Yes & Yes & Yes & Yes & Yes \\
Observations & Yes & Yes & Yes & Yes & Yes \\
Adjusted R-squared & 718 & 718 & 718 & 718 & 718 \\
& 0.389 & 0.391 & 0.391 & 0.398 & 0.405 \\
Hansen's J-test (p-value) & & & & & \\
First-stage Instrumental Variables' Joint & 0.353 & 0.297 & 0.262 & 0.259 & 0.338 \\
Significance (F-stat) & & & & & 76.77 \\
\hline
\end{tabular}

Panel B: A subsample of firms with Bond Ratings of BBB-and Better (527 Obs.)

\begin{tabular}{|c|c|c|c|c|c|c|}
\hline & & $(1)$ & $(2)$ & (3) & (4) & $(5)$ \\
\hline \multicolumn{7}{|l|}{$\underline{\text { CEO Employment History Variables }}$} \\
\hline \# Employers & $(+)$ & $\begin{array}{l}0.002 * * \\
(0.033)\end{array}$ & & & & \\
\hline \# Employer Changes per year & $(+)$ & & $\begin{array}{c}0.051^{* *} \\
(0.033)\end{array}$ & & & \\
\hline Employer Change Recency & $(+)$ & & & $\begin{array}{l}0.003^{*} \\
(0.056)\end{array}$ & & \\
\hline Firm Experience Diversification & $(-)$ & & & & $\begin{array}{c}-0.009 * * \\
(0.047)\end{array}$ & \\
\hline $\begin{array}{l}\text { Industry Experience } \\
\text { Diversification }\end{array}$ & $(-)$ & & & & & $\begin{array}{l}-0.007 * \\
(0.057)\end{array}$ \\
\hline \multicolumn{7}{|l|}{ Firm Characteristics } \\
\hline Pre-turnover Spread & & $\begin{array}{c}0.217^{* *} \\
(0.044)\end{array}$ & $\begin{array}{l}0.207^{*} \\
(0.056)\end{array}$ & $\begin{array}{l}0.213^{* *} \\
(0.041)\end{array}$ & $\begin{array}{l}0.216^{* *} \\
(0.033)\end{array}$ & $\begin{array}{l}0.198^{* *} \\
(0.049)\end{array}$ \\
\hline Duration & & $\begin{array}{l}-0.001 \\
(0.100) \\
\end{array}$ & $\begin{array}{l}-0.001 \\
(0.103)\end{array}$ & $\begin{array}{l}-0.001 * \\
(0.088) \\
\end{array}$ & $\begin{array}{l}-0.001 * \\
(0.057) \\
\end{array}$ & $\begin{array}{l}-0.001 * \\
(0.096) \\
\end{array}$ \\
\hline
\end{tabular}


Table 22 Continued.

\begin{tabular}{|c|c|c|c|c|c|}
\hline \multicolumn{6}{|l|}{ Firm Characteristics (Continued) } \\
\hline \multirow[t]{2}{*}{ Convexity } & 0.000 & 0.000 & 0.000 & $0.000 *$ & 0.000 \\
\hline & $(0.195)$ & $(0.197)$ & $(0.137)$ & $(0.095)$ & $(0.132)$ \\
\hline \multirow[t]{2}{*}{$\ln ($ Total Sales $)$} & -0.001 & -0.001 & -0.001 & -0.001 & $-0.002 * * *$ \\
\hline & $(0.168)$ & $(0.154)$ & $(0.101)$ & $(0.107)$ & $(0.010)$ \\
\hline \multirow[t]{2}{*}{ Firm Age } & 0.001 & 0.001 & 0.001 & 0.001 & 0.001 \\
\hline & $(0.567)$ & $(0.568)$ & $(0.585)$ & $(0.443)$ & $(0.566)$ \\
\hline \multirow[t]{2}{*}{ Annual Stock Return } & -0.001 & -0.001 & -0.001 & -0.001 & -0.001 \\
\hline & $(0.496)$ & $(0.549)$ & $(0.378)$ & $(0.439)$ & $(0.444)$ \\
\hline \multirow[t]{2}{*}{ Tobin’s Q } & $-0.000 * *$ & $-0.000 * *$ & $-0.000 * *$ & $-0.000 * *$ & $-0.000 * *$ \\
\hline & $(0.020)$ & $(0.022)$ & $(0.020)$ & $(0.015)$ & $(0.026)$ \\
\hline \multirow[t]{2}{*}{ Leverage } & $0.012 * * *$ & $0.013 * * *$ & $0.013 * * *$ & $0.014 * * *$ & $0.014 * * *$ \\
\hline & $(0.000)$ & $(0.000)$ & $(0.000)$ & $(0.000)$ & $(0.000)$ \\
\hline Pay Directors Equity Based & 0.002 & 0.003 & $0.003 *$ & 0.002 & 0.002 \\
\hline Compensation $(0 / 1)$ & $(0.121)$ & $(0.113)$ & $(0.092)$ & $(0.199)$ & $(0.220)$ \\
\hline \multirow[t]{2}{*}{ Activist Institutional Holding (\%) } & -0.005 & 0.000 & -0.010 & -0.001 & 0.006 \\
\hline & $(0.949)$ & $(0.997)$ & $(0.897)$ & $(0.991)$ & $(0.928)$ \\
\hline \multirow[t]{2}{*}{ CEO Cash Compensation } & $0.006 * * *$ & $0.006 * * *$ & $0.006^{* * *}$ & $0.006^{* * *}$ & $0.006 * * *$ \\
\hline & $(0.000)$ & $(0.000)$ & $(0.000)$ & $(0.001)$ & $(0.001)$ \\
\hline \multirow[t]{2}{*}{ CEO Compensation Delta } & 0.001 & 0.001 & 0.001 & 0.002 & 0.001 \\
\hline & $(0.280)$ & $(0.252)$ & $(0.380)$ & $(0.245)$ & $(0.327)$ \\
\hline \multirow[t]{2}{*}{ CEO Compensation Vega } & -0.004 & $-0.004 *$ & -0.003 & -0.003 & -0.003 \\
\hline & $(0.119)$ & $(0.095)$ & $(0.169)$ & $(0.161)$ & $(0.168)$ \\
\hline \multirow[t]{2}{*}{ Herfindhal Index } & 0.020 & 0.022 & 0.020 & 0.025 & 0.021 \\
\hline & $(0.385)$ & $(0.325)$ & $(0.393)$ & $(0.264)$ & $(0.370)$ \\
\hline \multicolumn{6}{|l|}{ CEO Characteristics } \\
\hline \multirow[t]{2}{*}{ Ln(CEO Tenure+1) } & 0.001 & 0.001 & 0.001 & 0.001 & 0.001 \\
\hline & $(0.552)$ & $(0.586)$ & $(0.478)$ & $(0.529)$ & $(0.443)$ \\
\hline \multirow[t]{2}{*}{ CEO Age } & 0.001 & 0.010 & -0.000 & 0.001 & 0.001 \\
\hline & $(0.923)$ & $(0.226)$ & $(0.968)$ & $(0.940)$ & $(0.892)$ \\
\hline \multirow{2}{*}{$\operatorname{MBA}(0 / 1)$} & 0.002 & 0.002 & 0.002 & 0.002 & 0.002 \\
\hline & $(0.278)$ & $(0.283)$ & $(0.320)$ & $(0.372)$ & $(0.311)$ \\
\hline \multirow[t]{2}{*}{ Founder $(0 / 1)$} & 0.005 & $0.006^{*}$ & $0.005^{*}$ & 0.006 & 0.005 \\
\hline & $(0.125)$ & $(0.099)$ & $(0.093)$ & $(0.106)$ & $(0.118)$ \\
\hline \multirow[t]{2}{*}{ \# Functional Areas } & $-0.002 * *$ & $-0.001 * *$ & $-0.001 *$ & $-0.001 *$ & $-0.001 *$ \\
\hline & $(0.026)$ & $(0.037)$ & $(0.055)$ & $(0.079)$ & $(0.061)$ \\
\hline \multirow[t]{2}{*}{ Has Finance Background (0/1) } & 0.003 & 0.003 & 0.003 & 0.003 & 0.002 \\
\hline & $(0.101)$ & $(0.112)$ & $(0.134)$ & $(0.143)$ & $(0.247)$ \\
\hline \multirow[t]{2}{*}{ Constant } & -0.006 & -0.043 & -0.000 & 0.005 & 0.008 \\
\hline & $(0.849)$ & $(0.254)$ & $(0.992)$ & $(0.883)$ & $(0.811)$ \\
\hline Year Dummies & Yes & Yes & Yes & Yes & Yes \\
\hline Industry Dummies & Yes & Yes & Yes & Yes & Yes \\
\hline Observations & 527 & 527 & 527 & 527 & 527 \\
\hline Adjusted R-squared & 0.365 & 0.359 & 0.368 & 0.364 & 0.372 \\
\hline Hansen's J-test (p-value) & 0.269 & 0.300 & 0.189 & 0.247 & 0.172 \\
\hline \multicolumn{6}{|l|}{ First-stage Instrumental Variables' Joint } \\
\hline Significance (F-stat) & 13.82 & 13.02 & 13.35 & 19.45 & 69.1 \\
\hline
\end{tabular}




\section{Table 23. CEO Employment History and the S\&P Credit Ratings}

This table presents IV/2SLS results for a firm's bond ratings on a sample of 1,998 firm years. The dependent variable is the S\&P credit rating number. Rating of AAA has a value of 1 for the rating number variable and B- has a value of 16 for the rating number variable. Appendix A contains information on how credit rating letters are converted to rating numbers. Also refer to Table 1 and Appendix A for variable definitions. Instrumental variables are the unemployment rate for the year when the CEO started his first full-time job, non-business career dummy that equals one if the CEO had academic or government jobs, and the number of years the CEO has worked in his current firm's industry. Pre-turnover credit rating is the firm's credit rating in the year before the CEO turnover year. I report p-values of Hansen's J-test and first-stage $F$-stat at the bottom of the table. The values of the five CEO employment history proxies in the IV/2SLS estimations are predicted values. The predicted signs for the CEO employment history proxies are presented in parenthesis at the beginning of each row. I report $p$-values based on robust standard errors clustered at the firm level in parenthesis. $* * *, * *$, and $*$ indicate significance at the 1,5 , and $10 \%$ levels, respectively.

Panel A: Whole Sample (1,998 Obs)

\begin{tabular}{|c|c|c|c|c|c|c|}
\hline & & $(1)$ & $(2)$ & (3) & (4) & $(5)$ \\
\hline \multicolumn{7}{|l|}{ CEO Employment History Variables } \\
\hline \# Employers & $(+)$ & $\begin{array}{l}0.096 \\
(0.115)\end{array}$ & & & & \\
\hline \# Employer Changes per year & $(+)$ & & $\begin{array}{c}2.979 \\
(0.129)\end{array}$ & & & \\
\hline Employer Change Recency & $(+)$ & & & $\begin{array}{c}0.144 \\
(0.143)\end{array}$ & & \\
\hline Firm Experience Diversification & $(-)$ & & & & $\begin{array}{l}-0.468 \\
(0.200)\end{array}$ & \\
\hline $\begin{array}{l}\text { Industry Experience } \\
\text { Diversification }\end{array}$ & $(-)$ & & & & & $\begin{array}{l}-0.353 \\
(0.388)\end{array}$ \\
\hline \multicolumn{7}{|l|}{$\underline{\text { Firm Characteristics }}$} \\
\hline Pre-turnover Ratings & & $\begin{array}{c}0.646^{* * *} \\
(0.000)\end{array}$ & $\begin{array}{c}0.644 * * * \\
(0.000)\end{array}$ & $\begin{array}{c}0.646^{* * *} \\
(0.000)\end{array}$ & $\begin{array}{c}0.650^{* * * *} \\
(0.000)\end{array}$ & $\begin{array}{c}0.655^{* * *} \\
(0.000)\end{array}$ \\
\hline $\ln$ (Total Sales) & & $\begin{array}{c}-0.420 * * * \\
(0.000)\end{array}$ & $\begin{array}{c}-0.421 * * * \\
(0.000)\end{array}$ & $\begin{array}{c}-0.425^{* * *} \\
(0.000)\end{array}$ & $\begin{array}{c}-0.423 * * * \\
(0.000)\end{array}$ & $\begin{array}{c}-0.432 * * * \\
(0.000)\end{array}$ \\
\hline Firm Age & & $\begin{array}{l}-0.047 \\
(0.696)\end{array}$ & $\begin{array}{l}-0.042 \\
(0.722)\end{array}$ & $\begin{array}{l}-0.037 \\
(0.754)\end{array}$ & $\begin{array}{l}-0.023 \\
(0.844)\end{array}$ & $\begin{array}{l}-0.034 \\
(0.772)\end{array}$ \\
\hline Annual Stock Return & & $\begin{array}{c}0.352^{* * *} \\
(0.001)\end{array}$ & $\begin{array}{c}0.350^{* * *} \\
(0.001)\end{array}$ & $\begin{array}{l}0.343 * * * \\
(0.001)\end{array}$ & $\begin{array}{c}0.353 * * * \\
(0.001)\end{array}$ & $\begin{array}{c}0.354^{* * *} \\
(0.001)\end{array}$ \\
\hline Tobin's Q & & $\begin{array}{c}-0.057^{* *} \\
(0.010)\end{array}$ & $\begin{array}{c}-0.057 * * * \\
(0.010)\end{array}$ & $\begin{array}{c}-0.058 * * * \\
(0.009)\end{array}$ & $\begin{array}{c}-0.057 * * \\
(0.011)\end{array}$ & $\begin{array}{c}-0.056^{* *} \\
(0.012)\end{array}$ \\
\hline Leverage & & $\begin{array}{c}2.033^{* *} \\
(0.041)\end{array}$ & $\begin{array}{l}2.033^{* *} \\
(0.041)\end{array}$ & $\begin{array}{l}2.053 * * \\
(0.038)\end{array}$ & $\begin{array}{l}2.061 * * \\
(0.037)\end{array}$ & $\begin{array}{l}2.082 * * \\
(0.035)\end{array}$ \\
\hline Pay Directors Equity Based & & 0.047 & 0.051 & 0.053 & 0.060 & 0.062 \\
\hline Compensation $(0 / 1)$ & & $(0.750)$ & $(0.731)$ & $(0.719)$ & $(0.682)$ & $(0.671)$ \\
\hline Activist Institutional Holding (\%) & & $\begin{array}{l}-1.427 \\
(0.807)\end{array}$ & $\begin{array}{l}-1.236 \\
(0.832)\end{array}$ & $\begin{array}{l}-1.435 \\
(0.807)\end{array}$ & $\begin{array}{l}-1.642 \\
(0.779)\end{array}$ & $\begin{array}{l}-2.024 \\
(0.735)\end{array}$ \\
\hline CEO Cash Compensation & & $\begin{array}{l}0.348 * * \\
(0.048)\end{array}$ & $\begin{array}{l}0.348^{* *} \\
(0.049)\end{array}$ & $\begin{array}{l}0.341^{*} \\
(0.053)\end{array}$ & $\begin{array}{l}0.355^{* *} \\
(0.043)\end{array}$ & $\begin{array}{c}0.356^{* *} \\
(0.043)\end{array}$ \\
\hline CEO Compensation Delta & & $\begin{array}{l}-0.179 \\
(0.275)\end{array}$ & $\begin{array}{l}-0.178 \\
(0.278)\end{array}$ & $\begin{array}{l}-0.191 \\
(0.239)\end{array}$ & $\begin{array}{l}-0.187 \\
(0.242)\end{array}$ & $\begin{array}{l}-0.182 \\
(0.261)\end{array}$ \\
\hline CEO Compensation Vega & & $\begin{array}{l}-0.219 \\
(0.402)\end{array}$ & $\begin{array}{l}-0.226 \\
(0.388)\end{array}$ & $\begin{array}{l}-0.203 \\
(0.436)\end{array}$ & $\begin{array}{l}-0.212 \\
(0.412)\end{array}$ & $\begin{array}{l}-0.213 \\
(0.414)\end{array}$ \\
\hline Herfindhal Index & & $\begin{array}{l}-0.285 \\
(0.795)\end{array}$ & $\begin{array}{l}-0.292 \\
(0.790)\end{array}$ & $\begin{array}{l}-0.309 \\
(0.779)\end{array}$ & $\begin{array}{l}-0.371 \\
(0.741)\end{array}$ & $\begin{array}{l}-0.429 \\
(0.700)\end{array}$ \\
\hline
\end{tabular}




\begin{tabular}{lccccc} 
Table 23 Continued & \multicolumn{5}{c}{} \\
\hline CEO Characteristics & -0.119 & -0.124 & -0.101 & -0.120 & -0.124 \\
Ln(CEO Tenure+1) & $(0.475)$ & $(0.457)$ & $(0.537)$ & $(0.459)$ & $(0.449)$ \\
& -0.351 & 0.113 & -0.369 & -0.333 & -0.335 \\
CEO Age & $(0.672)$ & $(0.894)$ & $(0.657)$ & $(0.688)$ & $(0.689)$ \\
& 0.236 & 0.231 & 0.237 & 0.239 & 0.247 \\
MBA (0/1) & $(0.214)$ & $(0.226)$ & $(0.214)$ & $(0.211)$ & $(0.199)$ \\
& 0.585 & 0.604 & 0.580 & 0.594 & 0.539 \\
Founder (0/1) & $(0.147)$ & $(0.131)$ & $(0.150)$ & $(0.142)$ & $(0.189)$ \\
& -0.055 & -0.049 & -0.036 & -0.038 & -0.035 \\
\# Functional Areas & $(0.552)$ & $(0.596)$ & $(0.684)$ & $(0.670)$ & $(0.701)$ \\
& 0.177 & 0.171 & 0.179 & 0.176 & 0.164 \\
Has Finance Background (0/1) & $(0.339)$ & $(0.355)$ & $(0.333)$ & $(0.339)$ & $(0.369)$ \\
& $7.252^{* *}$ & 5.424 & $7.354 * *$ & $7.579 * *$ & $7.538^{* *}$ \\
Constant & $(0.026)$ & $(0.112)$ & $(0.024)$ & $(0.021)$ & $(0.024)$ \\
& Yes & Yes & Yes & Yes & Yes \\
Year Dummies & Yes & Yes & Yes & Yes & Yes \\
Industry Dummies & 1998 & 1998 & 1998 & 1998 & 1998 \\
Observations & 0.768 & 0.767 & 0.769 & 0.768 & 0.767 \\
Adjusted R-squared & & & & & \\
& 0.137 & 0.135 & 0.128 & 0.116 & 0.108 \\
Hansen's J-test (p-value) & & & & & 107.04 \\
First-stage Instrumental Variables' Joint & 88.97 & 82.32 & 93.96 & 107.09 & \\
Significance (F-stat) & & & &
\end{tabular}

Panel B: A subsample of firms with Bond Ratings of BBB- and Better (1,204 Obs)

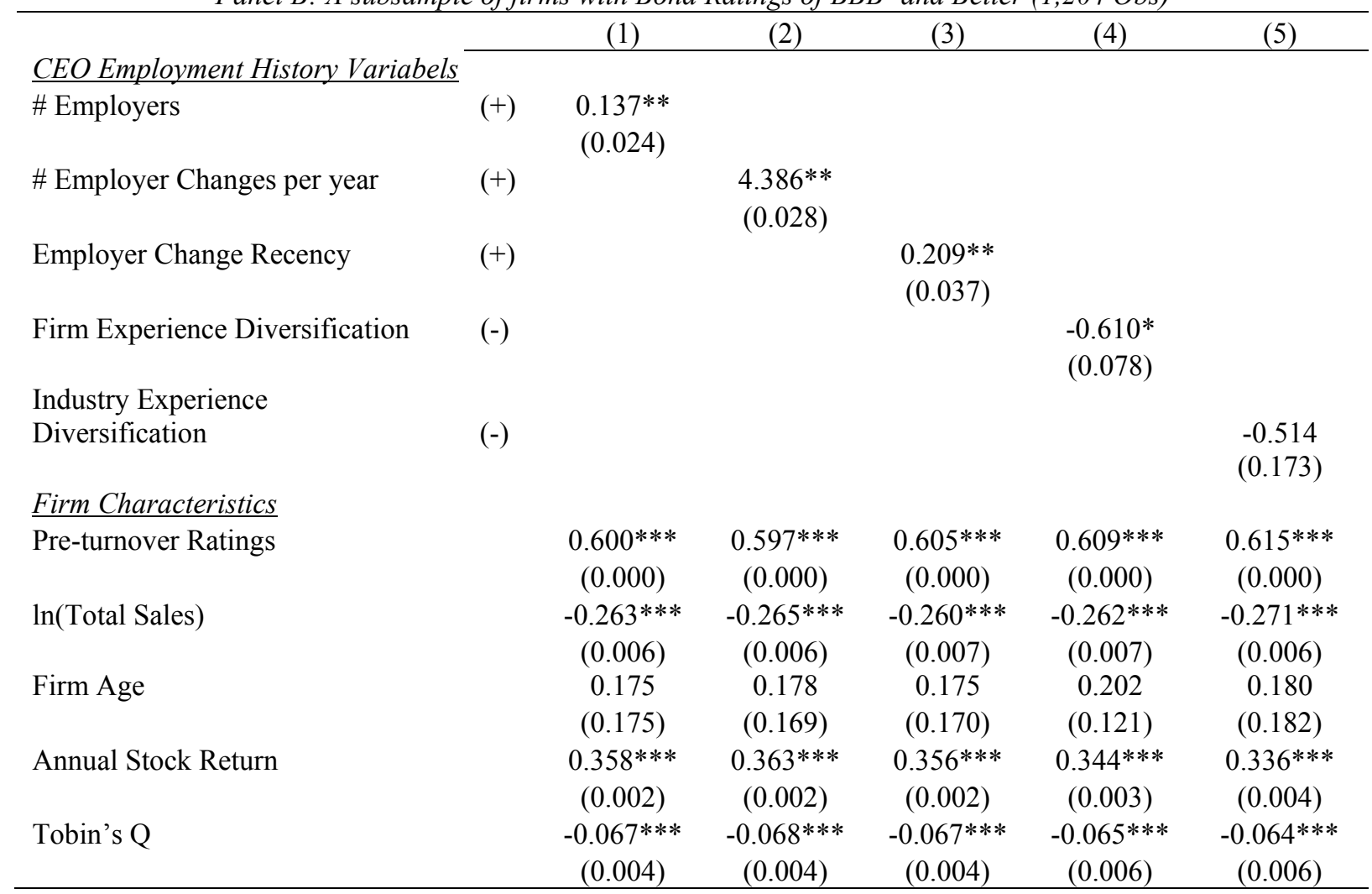


Table 23 Continued.

\begin{tabular}{|c|c|c|c|c|c|}
\hline \multicolumn{6}{|l|}{ Firm Characteristics (Continued) } \\
\hline Leverage & $\begin{array}{c}0.691 \\
(0.460)\end{array}$ & $\begin{array}{c}0.703 \\
(0.453)\end{array}$ & $\begin{array}{c}0.719 \\
(0.437)\end{array}$ & $\begin{array}{c}0.746 \\
(0.419)\end{array}$ & $\begin{array}{c}0.770 \\
(0.409)\end{array}$ \\
\hline Pay Directors Equity Based & 0.183 & 0.195 & 0.191 & 0.184 & 0.177 \\
\hline Compensation $(0 / 1)$ & $(0.253)$ & $(0.226)$ & $(0.227)$ & $(0.241)$ & $(0.269)$ \\
\hline Activist Institutional Holding (\%) & $\begin{array}{c}3.636 \\
(0.593)\end{array}$ & $\begin{array}{c}3.995 \\
(0.559)\end{array}$ & $\begin{array}{c}3.842 \\
(0.580)\end{array}$ & $\begin{array}{c}3.487 \\
(0.608)\end{array}$ & $\begin{array}{c}4.036 \\
(0.560)\end{array}$ \\
\hline CEO Cash Compensation & $\begin{array}{l}-0.157 \\
(0.442)\end{array}$ & $\begin{array}{l}-0.160 \\
(0.435)\end{array}$ & $\begin{array}{l}-0.155 \\
(0.439)\end{array}$ & $\begin{array}{l}-0.144 \\
(0.474)\end{array}$ & $\begin{array}{l}-0.134 \\
(0.508)\end{array}$ \\
\hline CEO Compensation Delta & $\begin{array}{c}-0.308 * * * \\
(0.004)\end{array}$ & $\begin{array}{c}-0.309 * * * \\
(0.004)\end{array}$ & $\begin{array}{c}-0.325 * * * \\
(0.003)\end{array}$ & $\begin{array}{c}-0.314 * * * \\
(0.004)\end{array}$ & $\begin{array}{c}-0.314 * * * \\
(0.004)\end{array}$ \\
\hline CEO Compensation Vega & $\begin{array}{c}0.099 \\
(0.631)\end{array}$ & $\begin{array}{c}0.090 \\
(0.662)\end{array}$ & $\begin{array}{c}0.111 \\
(0.593)\end{array}$ & $\begin{array}{c}0.104 \\
(0.613)\end{array}$ & $\begin{array}{c}0.105 \\
(0.613)\end{array}$ \\
\hline Herfindhal Index & $\begin{array}{c}2.155 \\
(0.162)\end{array}$ & $\begin{array}{c}2.235 \\
(0.149)\end{array}$ & $\begin{array}{c}1.993 \\
(0.184)\end{array}$ & $\begin{array}{c}1.927 \\
(0.219)\end{array}$ & $\begin{array}{c}1.871 \\
(0.228)\end{array}$ \\
\hline \multicolumn{6}{|l|}{$\underline{\text { CEO Characteristics }}$} \\
\hline$\overline{\operatorname{Ln}(\mathrm{CEO} \text { Tenure }+1)}$ & $\begin{array}{l}-0.117 \\
(0.608)\end{array}$ & $\begin{array}{l}-0.124 \\
(0.586)\end{array}$ & $\begin{array}{l}-0.072 \\
(0.745)\end{array}$ & $\begin{array}{l}-0.112 \\
(0.612)\end{array}$ & $\begin{array}{l}-0.120 \\
(0.592)\end{array}$ \\
\hline CEO Age & $\begin{array}{l}-1.044 \\
(0.226)\end{array}$ & $\begin{array}{l}-0.376 \\
(0.677)\end{array}$ & $\begin{array}{l}-1.124 \\
(0.192)\end{array}$ & $\begin{array}{l}-1.027 \\
(0.236)\end{array}$ & $\begin{array}{l}-1.068 \\
(0.231)\end{array}$ \\
\hline $\operatorname{MBA}(0 / 1)$ & $\begin{array}{l}0.326^{*} \\
(0.064)\end{array}$ & $\begin{array}{l}0.328^{*} \\
(0.063)\end{array}$ & $\begin{array}{l}0.328^{*} \\
(0.066)\end{array}$ & $\begin{array}{l}0.330^{*} \\
(0.062)\end{array}$ & $\begin{array}{c}0.349^{* *} \\
(0.050)\end{array}$ \\
\hline Founder $(0 / 1)$ & $\begin{array}{c}0.579 \\
(0.142)\end{array}$ & $\begin{array}{c}0.622 \\
(0.110)\end{array}$ & $\begin{array}{c}0.606 \\
(0.132)\end{array}$ & $\begin{array}{c}0.618 \\
(0.123)\end{array}$ & $\begin{array}{c}0.597 \\
(0.156)\end{array}$ \\
\hline \# Functional Areas & $\begin{array}{l}-0.026 \\
(0.776)\end{array}$ & $\begin{array}{l}-0.022 \\
(0.815)\end{array}$ & $\begin{array}{c}0.001 \\
(0.992)\end{array}$ & $\begin{array}{c}0.010 \\
(0.913)\end{array}$ & $\begin{array}{c}0.009 \\
(0.917)\end{array}$ \\
\hline Has Finance Background $(0 / 1)$ & $\begin{array}{c}0.071 \\
(0.708)\end{array}$ & $\begin{array}{c}0.057 \\
(0.764)\end{array}$ & $\begin{array}{c}0.068 \\
(0.718)\end{array}$ & $\begin{array}{c}0.070 \\
(0.712)\end{array}$ & $\begin{array}{c}0.046 \\
(0.808)\end{array}$ \\
\hline Constant & $\begin{array}{c}8.686^{* * *} \\
(0.005)\end{array}$ & $\begin{array}{l}6.031^{*} \\
(0.064)\end{array}$ & $\begin{array}{c}9.006^{* * *} \\
(0.003)\end{array}$ & $\begin{array}{c}9.053^{* * *} \\
(0.004)\end{array}$ & $\begin{array}{c}9.186^{* * * *} \\
(0.005)\end{array}$ \\
\hline Year Dummies & Yes & Yes & Yes & Yes & Yes \\
\hline Industry Dummies & Yes & Yes & Yes & Yes & Yes \\
\hline Observations & 1204 & 1204 & 1204 & 1204 & 1204 \\
\hline Adjusted R-squared & 0.704 & 0.703 & 0.706 & 0.704 & 0.700 \\
\hline $\begin{array}{l}\text { Hansen's J-test (p-value) } \\
\text { First-stage Instrumental Variables' Joint }\end{array}$ & 0.269 & 0.244 & 0.213 & 0.144 & 0.118 \\
\hline Significance (F-stat) & 72.51 & 61.40 & 79.38 & 99.29 & 109.27 \\
\hline
\end{tabular}


B.1 Alternative Model Specifications

(1). Alternative Dependent Variables

Table B.1.1: Use industry-median-adjusted policies as dependent variables

Table B.1.2: Use change in policies as dependent variables

Table B.1.3: Use Book Leverage as the dependent variable

Table B.1.4: Use Intangible Ratio as the dependent variable

Table B.1.5: Use Four-factor model betas as dependent variables

(2). Alternative CEO Employment History Measures

Table B.1.6: Using values in the year of CEO turnover for CEO employment history measures (The values for these variables will not change for every firm year)

Table B.1.7: Including an interaction term between CEO employment history and a dummy variable that equals one if the respective pre-turnover firm policy is above industry median.

(3). Control Variables

Table B.1.8: Subsample with Board Size and Insider Ratio Information

Table B.1.9: Include a insider dummy

Table B.1.10: Industry Dummies, no Herfindhal Index

B.2 Alternative Estimation Methods

Table B.2.1: OLS Results

Table B.2.2: Between effects

Table B.2.3: Heckman Selection Model when the dependent variable is a dummy variable that equals one if the $\mathrm{CEO}$ has worked for more than five employers and zero otherwise

Table B.2.4: Subsamples of the first-five (three) years' policy of CEOs that have been the CEO for five (three) or more years

Table B.2.5: Comparison of long-run performance using a matched sample

B.3 Results for other CEO employment history variables.

These results are discussed in the text, but only presented for \#Employer. This section include the results for other four CEO employment history variables

Table B.3.1: Univariate Comparison for Pre-turnover firm policies 
Table B.1.1: Use Industry-median-adjusted Policies as Dependent Variables

This table presents IV/2SLS results for post-turnover industry-median-adjusted firm policies and risk. The dependent variables are listed at the top of each column. Refer to Table 1 and Appendix A for variable definitions. Pre-turnover firm policies are the respective firm policies in the year before the CEO turnover year. Instrumental variables for \#Employers are the unemployment rate for the year when the CEO started his first fulltime job, nonbusiness career dummy that equals one if the CEO had academic or government jobs, and the number of years the CEO has worked in his current firm's industry. The instrumental variable for CEO employment history*Industry Homogeneity in the R\&D regression is the unemployment rate described above multiplied by industry homogeneity. The predicted signs for the CEO employment history proxies are presented in parenthesis at the top of each column. I report $p$-values based on robust standard errors clustered at the firm level in parenthesis. ${ }^{* * *}, * *$, and $*$ indicate significance at the 1,5 , and $10 \%$ levels, respectively.

\begin{tabular}{|c|c|c|c|c|c|c|c|c|}
\hline & Leverage & CAPEXP & $R \& D$ & Adv. & $\begin{array}{l}\text { Total Risk } \\
\text { (Daily } \\
\text { Stock Ret. } \\
\text { Std.) }\end{array}$ & $\begin{array}{c}\text { Market } \\
\text { Risk } \\
\text { (CAPM) }\end{array}$ & $\begin{array}{c}\text { Firm- } \\
\text { specific } \\
\text { Risk } \\
\text { (CAPM) }\end{array}$ & $\begin{array}{c}\text { Firm- } \\
\text { specific } \\
\text { Risk } \\
\text { (4- Factor) }\end{array}$ \\
\hline \#Employers & $\begin{array}{c}(+) \\
0.009 * \\
(0.086)\end{array}$ & $\begin{array}{c}(-) \\
-0.004^{* * *} \\
(0.005)\end{array}$ & $\begin{array}{c}(+) \\
-0.016^{* *} \\
(0.013)\end{array}$ & $\begin{array}{c}(+) \\
0.001^{*} \\
(0.057)\end{array}$ & $\begin{array}{c}(+) \\
0.005 \\
(0.128)\end{array}$ & $\begin{array}{c}(+) \\
-0.012 \\
(0.287)\end{array}$ & $\begin{array}{c}(+) \\
0.006^{*} \\
(0.052)\end{array}$ & $\begin{array}{c}(+) \\
0.007^{* *} \\
(0.029)\end{array}$ \\
\hline $\begin{array}{l}\text { \#Employers * Ind. } \\
\text { Homogeneity } \\
\text { Firm Characteristics }\end{array}$ & & & $\begin{array}{c}0.070 * * \\
(0.027)\end{array}$ & & & & & \\
\hline Pre-turnover Policy & $\begin{array}{c}0.313 * * * \\
(0.000)\end{array}$ & $\begin{array}{c}0.306^{* * *} \\
(0.000)\end{array}$ & $\begin{array}{c}0.496 * * * \\
(0.000)\end{array}$ & $\begin{array}{c}0.537 * * * \\
(0.000)\end{array}$ & $\begin{array}{c}0.183 * * * \\
(0.000)\end{array}$ & $\begin{array}{c}0.177 * * * \\
(0.000)\end{array}$ & $\begin{array}{c}0.184^{* * *} \\
(0.000)\end{array}$ & $\begin{array}{c}0.182 * * * \\
(0.000)\end{array}$ \\
\hline $\ln$ (Total Sales) & $\begin{array}{l}0.022^{* * *} \\
(0.000)\end{array}$ & $\begin{array}{c}-0.003 * * * \\
(0.009)\end{array}$ & $\begin{array}{c}-0.002 * * \\
(0.016)\end{array}$ & $\begin{array}{c}0.001 \\
(0.169)\end{array}$ & $\begin{array}{c}-0.018^{* * *} \\
(0.000)\end{array}$ & $\begin{array}{c}-0.036^{* * *} \\
(0.000)\end{array}$ & $\begin{array}{c}-0.019 * * * \\
(0.000)\end{array}$ & $\begin{array}{c}-0.018^{* * *} \\
(0.000)\end{array}$ \\
\hline Firm Age & $\begin{array}{l}-0.005 \\
(0.469)\end{array}$ & $\begin{array}{c}0.001 \\
(0.767)\end{array}$ & $\begin{array}{c}-0.005^{* * *} \\
(0.001)\end{array}$ & $\begin{array}{c}0.001 \\
(0.152)\end{array}$ & $\begin{array}{c}-0.022 * * * \\
(0.000)\end{array}$ & $\begin{array}{c}-0.059 * * * \\
(0.000)\end{array}$ & $\begin{array}{c}-0.020 * * * \\
(0.000)\end{array}$ & $\begin{array}{c}-0.019 * * * \\
(0.000)\end{array}$ \\
\hline $\begin{array}{l}\text { Operating Return on } \\
\text { Assets }\end{array}$ & $\begin{array}{c}-0.565^{* * *} \\
(0.000)\end{array}$ & & & & $\begin{array}{c}-0.199 * * * \\
(0.000)\end{array}$ & $\begin{array}{c}-0.622 * * * \\
(0.000)\end{array}$ & $\begin{array}{c}-0.154 * * * \\
(0.000)\end{array}$ & $\begin{array}{c}-0.138^{* * *} \\
(0.000)\end{array}$ \\
\hline Surplus Cash & & $\begin{array}{l}0.018^{* *} \\
(0.049)\end{array}$ & $\begin{array}{c}0.146^{* * *} \\
(0.000)\end{array}$ & $\begin{array}{l}-0.010 \\
(0.299)\end{array}$ & & & & \\
\hline Tobin's Q & $\begin{array}{c}-0.018^{* * *} \\
(0.000)\end{array}$ & $\begin{array}{l}0.002 * * * \\
(0.005)\end{array}$ & $\begin{array}{l}-0.001 \\
(0.437)\end{array}$ & $\begin{array}{l}0.001 * * \\
(0.014)\end{array}$ & $\begin{array}{c}0.003 \\
(0.322)\end{array}$ & $\begin{array}{l}0.045^{* * *} \\
(0.000)\end{array}$ & $\begin{array}{l}-0.000 \\
(0.872)\end{array}$ & $\begin{array}{l}-0.001 \\
(0.726)\end{array}$ \\
\hline R\&D/Total Assets & $\begin{array}{c}-0.319^{* * *} \\
(0.000)\end{array}$ & $\begin{array}{l}-0.040^{*} \\
(0.075)\end{array}$ & & $\begin{array}{c}0.003 \\
(0.829)\end{array}$ & $\begin{array}{c}0.265^{* * *} \\
(0.003)\end{array}$ & $\begin{array}{c}0.802 * * * \\
(0.005)\end{array}$ & $\begin{array}{c}0.237 * * * \\
(0.004)\end{array}$ & $\begin{array}{c}0.220 * * * \\
(0.004)\end{array}$ \\
\hline Adv./Total Assets & & $\begin{array}{c}0.029 \\
(0.414)\end{array}$ & $\begin{array}{l}-0.037 \\
(0.321)\end{array}$ & & $\begin{array}{c}0.165 \\
(0.281)\end{array}$ & $\begin{array}{c}0.135 \\
(0.671)\end{array}$ & $\begin{array}{c}0.197 \\
(0.217)\end{array}$ & $\begin{array}{c}0.199 \\
(0.206)\end{array}$ \\
\hline CAPEXP & & & $\begin{array}{l}-0.021 \\
(0.319)\end{array}$ & $\begin{array}{c}0.012 \\
(0.197)\end{array}$ & $\begin{array}{l}0.127^{*} \\
(0.054)\end{array}$ & $\begin{array}{c}0.214 \\
(0.254)\end{array}$ & $\begin{array}{l}0.123^{*} \\
(0.059)\end{array}$ & $\begin{array}{l}0.112 * \\
(0.079)\end{array}$ \\
\hline Leverage & & $\begin{array}{l}-0.008 \\
(0.273)\end{array}$ & $\begin{array}{c}0.007 \\
(0.278)\end{array}$ & $\begin{array}{l}-0.005 \\
(0.125)\end{array}$ & $\begin{array}{c}0.082 * * * \\
(0.001)\end{array}$ & $\begin{array}{c}0.094 \\
(0.171)\end{array}$ & $\begin{array}{c}0.086^{* * * *} \\
(0.000)\end{array}$ & $\begin{array}{c}0.085^{* * * *} \\
(0.000)\end{array}$ \\
\hline Industry Homogeneity & & & $(0.022)$ & $-0.228 * *$ & & & & \\
\hline Capital Intensity & $\begin{array}{c}0.117^{* * *} \\
(0.000)\end{array}$ & & & & & & & \\
\hline Depr./Total Assets & $\begin{array}{l}-0.148 \\
(0.419)\end{array}$ & & & & & & & \\
\hline $\begin{array}{l}\text { Pay Directors Equity } \\
\text { Based Compensation }\end{array}$ & $\begin{array}{c}0.007 \\
(0.286)\end{array}$ & $\begin{array}{l}-0.001 \\
(0.735)\end{array}$ & $\begin{array}{l}0.003 * \\
(0.095)\end{array}$ & $\begin{array}{l}0.002 * \\
(0.079)\end{array}$ & $\begin{array}{c}0.006 \\
(0.404)\end{array}$ & $\begin{array}{c}0.007 \\
(0.759)\end{array}$ & $\begin{array}{c}0.005 \\
(0.458)\end{array}$ & $\begin{array}{c}0.006 \\
(0.415)\end{array}$ \\
\hline
\end{tabular}


Table B.1.1 Continued

\begin{tabular}{|c|c|c|c|c|c|c|c|c|}
\hline \multicolumn{9}{|c|}{ Firm Characteristics (Continued) } \\
\hline $\begin{array}{l}\text { Activist Institutional } \\
\text { Holding (\%) }\end{array}$ & $\begin{array}{l}-0.155 \\
(0.543)\end{array}$ & $\begin{array}{l}-0.103 \\
(0.115)\end{array}$ & $\begin{array}{l}0.088^{*} \\
(0.093)\end{array}$ & $\begin{array}{l}-0.019 \\
(0.643)\end{array}$ & $\begin{array}{l}-0.278 \\
(0.171)\end{array}$ & $\begin{array}{l}1.407^{* *} \\
(0.023)\end{array}$ & $\begin{array}{l}-0.393^{*} \\
(0.058)\end{array}$ & $\begin{array}{r}-0.406^{* *} \\
(0.045)\end{array}$ \\
\hline $\begin{array}{l}\text { CEO Cash } \\
\text { Compensation }\end{array}$ & $\begin{array}{c}0.006 \\
(0.428)\end{array}$ & $\begin{array}{l}-0.003 \\
(0.117)\end{array}$ & $\begin{array}{c}0.008^{* * *} \\
(0.001)\end{array}$ & $\begin{array}{c}0.003 * * * \\
(0.007)\end{array}$ & $\begin{array}{l}-0.003 \\
(0.695)\end{array}$ & $\begin{array}{c}-0.055^{* *} \\
(0.023)\end{array}$ & $\begin{array}{l}-0.002 \\
(0.828)\end{array}$ & $\begin{array}{l}-0.001 \\
(0.846)\end{array}$ \\
\hline $\begin{array}{l}\text { CEO Compensation } \\
\text { Delta }\end{array}$ & $\begin{array}{l}-0.007^{*} \\
(0.085)\end{array}$ & $\begin{array}{l}-0.001 \\
(0.489)\end{array}$ & $\begin{array}{l}-0.000 \\
(0.953)\end{array}$ & $\begin{array}{c}0.001 \\
(0.118)\end{array}$ & $\begin{array}{l}-0.002 \\
(0.665)\end{array}$ & $\begin{array}{c}0.023 \\
(0.104)\end{array}$ & $\begin{array}{l}-0.003 \\
(0.359)\end{array}$ & $\begin{array}{l}-0.003 \\
(0.335)\end{array}$ \\
\hline $\begin{array}{l}\text { CEO Compensation } \\
\text { Vega }\end{array}$ & $\begin{array}{c}-0.026^{* * *} \\
(0.006)\end{array}$ & $\begin{array}{l}-0.001 \\
(0.746)\end{array}$ & $\begin{array}{l}0.003 \\
(0.181)\end{array}$ & $\begin{array}{l}-0.002 \\
(0.348)\end{array}$ & $\begin{array}{l}-0.009 \\
(0.332)\end{array}$ & $\begin{array}{c}-0.063 * * \\
(0.021)\end{array}$ & $\begin{array}{l}-0.008 \\
(0.372)\end{array}$ & $\begin{array}{l}-0.006 \\
(0.439)\end{array}$ \\
\hline Herfindhal Index & $\begin{array}{c}0.745^{* * *} \\
(0.000)\end{array}$ & $\begin{array}{l}-0.033 \\
(0.391)\end{array}$ & $\begin{array}{c}0.016 \\
(0.647)\end{array}$ & $\begin{array}{l}-0.003 \\
(0.885)\end{array}$ & $\begin{array}{c}0.225 \\
(0.129)\end{array}$ & $\begin{array}{c}0.001 \\
(0.998)\end{array}$ & $\begin{array}{c}0.157 \\
(0.246)\end{array}$ & $\begin{array}{c}0.153 \\
(0.253)\end{array}$ \\
\hline \multicolumn{9}{|l|}{ CEO Characteristics } \\
\hline$\overline{\operatorname{Ln}(\mathrm{CEO} \text { Tenure }+1)}$ & $\begin{array}{c}0.004 \\
(0.508)\end{array}$ & $\begin{array}{l}-0.002 \\
(0.222)\end{array}$ & $\begin{array}{l}-0.001 \\
(0.348)\end{array}$ & $\begin{array}{l}-0.000 \\
(0.570)\end{array}$ & $\begin{array}{l}-0.006 \\
(0.260)\end{array}$ & $\begin{array}{l}-0.008 \\
(0.569)\end{array}$ & $\begin{array}{l}-0.006 \\
(0.193)\end{array}$ & $\begin{array}{l}-0.006 \\
(0.187)\end{array}$ \\
\hline CEO Age & $\begin{array}{l}-0.060^{*} \\
(0.075)\end{array}$ & $\begin{array}{l}-0.012 \\
(0.168)\end{array}$ & $\begin{array}{c}-0.023 * * * \\
(0.006)\end{array}$ & $\begin{array}{l}-0.005 \\
(0.268)\end{array}$ & $\begin{array}{l}-0.041 \\
(0.123)\end{array}$ & $\begin{array}{c}0.061 \\
(0.439)\end{array}$ & $\begin{array}{l}-0.045^{*} \\
(0.086)\end{array}$ & $\begin{array}{l}-0.047^{*} \\
(0.067)\end{array}$ \\
\hline $\operatorname{MBA}(0 / 1)$ & $\begin{array}{c}0.016^{* *} \\
(0.035)\end{array}$ & $\begin{array}{l}-0.001 \\
(0.696)\end{array}$ & $\begin{array}{c}0.003 \\
(0.215)\end{array}$ & $\begin{array}{l}-0.001 \\
(0.346)\end{array}$ & $\begin{array}{l}-0.010^{*} \\
(0.093)\end{array}$ & $\begin{array}{l}-0.012 \\
(0.507)\end{array}$ & $\begin{array}{l}-0.009 \\
(0.104)\end{array}$ & $\begin{array}{l}-0.009^{*} \\
(0.091)\end{array}$ \\
\hline Founder $(0 / 1)$ & $\begin{array}{c}0.015 \\
(0.295)\end{array}$ & $\begin{array}{l}-0.006 \\
(0.103)\end{array}$ & $\begin{array}{l}-0.003 \\
(0.372)\end{array}$ & $\begin{array}{l}-0.000 \\
(0.812)\end{array}$ & $\begin{array}{c}0.018 \\
(0.109)\end{array}$ & $\begin{array}{c}0.037 \\
(0.290)\end{array}$ & $\begin{array}{c}0.016 \\
(0.118)\end{array}$ & $\begin{array}{c}0.016 \\
(0.117)\end{array}$ \\
\hline \# Functional Areas & $\begin{array}{l}-0.003 \\
(0.460)\end{array}$ & $\begin{array}{l}-0.000 \\
(0.820)\end{array}$ & $\begin{array}{c}0.001 \\
(0.556)\end{array}$ & $\begin{array}{l}-0.001 \\
(0.343)\end{array}$ & $\begin{array}{c}0.004 \\
(0.160)\end{array}$ & $\begin{array}{c}0.011 \\
(0.247)\end{array}$ & $\begin{array}{c}0.003 \\
(0.290)\end{array}$ & $\begin{array}{c}0.002 \\
(0.404)\end{array}$ \\
\hline $\begin{array}{l}\text { Has Finance } \\
\text { Background }(0 / 1)\end{array}$ & $\begin{array}{c}0.014 \\
(0.125)\end{array}$ & $\begin{array}{l}-0.004 \\
(0.127)\end{array}$ & $\begin{array}{c}-0.007 * * * \\
(0.003)\end{array}$ & $\begin{array}{l}-0.001 \\
(0.494)\end{array}$ & $\begin{array}{l}-0.003 \\
(0.702)\end{array}$ & $\begin{array}{c}0.002 \\
(0.919)\end{array}$ & $\begin{array}{l}-0.002 \\
(0.817)\end{array}$ & $\begin{array}{l}-0.001 \\
(0.851)\end{array}$ \\
\hline Constant & $\begin{array}{c}0.053 \\
(0.679)\end{array}$ & $\begin{array}{l}0.108^{* *} \\
(0.019)\end{array}$ & $\begin{array}{c}0.172 * * * \\
(0.000)\end{array}$ & $\begin{array}{c}0.017 \\
(0.361)\end{array}$ & $\begin{array}{c}0.144 \\
(0.193)\end{array}$ & $\begin{array}{c}0.437 \\
(0.193)\end{array}$ & $\begin{array}{c}0.165 \\
(0.124)\end{array}$ & $\begin{array}{l}0.175^{*} \\
(0.095)\end{array}$ \\
\hline Year Dummies & Yes & Yes & Yes & Yes & Yes & Yes & Yes & Yes \\
\hline Industry Dummies & Yes & Yes & Yes & Yes & Yes & Yes & Yes & Yes \\
\hline Observations & 4826 & 5029 & 4914 & 5074 & 4693 & 4693 & 4693 & 4693 \\
\hline R-squared & 0.500 & 0.272 & 0.628 & 0.574 & 0.516 & 0.230 & 0.534 & 0.537 \\
\hline Hansen's J-test (p-value) & 0.618 & 0.643 & 0.772 & 0.645 & 0.129 & 0.659 & 0.217 & 0.25 \\
\hline $\begin{array}{l}\text { First Stage } F \text {-stat for } \\
\text { \#Employers }\end{array}$ & 49.86 & 52.75 & 39.93 & 47.94 & 62.19 & 75.3 & 61.12 & 61.11 \\
\hline $\begin{array}{l}\text { First Stage F-stat for \#E } \\
\text { Homogeneity }\end{array}$ & Employers & ndustry & 26.85 & & & & & \\
\hline
\end{tabular}




\section{Table B.1.2: Use Changes in Policies as the Dependent Variables}

This table presents IV/2SLS results for changes in firm policies and risk. The dependent variables are listed at the top of each column. Refer to Table 1 and Appendix A for variable definitions. Pre-turnover firm policies are the respective firm policies in the year before the CEO turnover year. Instrumental variables for \#Employers are the unemployment rate for the year when the CEO started his first fulltime job, non-business career dummy that equals one if the CEO had academic or government jobs, and the number of years the CEO has worked in his current firm's industry. The instrumental variable for CEO employment history*Industry Homogeneity in the R\&D regression is the unemployment rate described above multiplied by industry homogeneity. The predicted signs for the CEO employment history proxies are presented in parenthesis at the top of each column. I report $p$-values based on robust standard errors clustered at the firm level in parenthesis.***,**, and * indicate significance at the 1,5 , and $10 \%$ levels, respectively.

\begin{tabular}{|c|c|c|c|c|c|c|c|c|}
\hline & Leverage & CAPEXP & $\mathrm{R} \& \mathrm{D}$ & Adv. & $\begin{array}{c}\text { Total Risk } \\
\text { (Daily } \\
\text { Stock } \\
\text { Return Std.) }\end{array}$ & $\begin{array}{c}\text { Market } \\
\text { Risk } \\
\text { (CAPM) }\end{array}$ & $\begin{array}{c}\text { Firm- } \\
\text { specific } \\
\text { Risk } \\
\text { (CAPM) }\end{array}$ & $\begin{array}{c}\text { Firm- } \\
\text { specific } \\
\text { Risk } \\
\text { (4- Factor) }\end{array}$ \\
\hline \multirow{3}{*}{ \#Employers } & $(+)$ & $(-)$ & $(+)$ & $(+)$ & $(+)$ & $(+)$ & $(+)$ & $(+)$ \\
\hline & $0.012 * *$ & $-0.004 * * *$ & $-0.013 * *$ & $0.001 *$ & $0.006^{*}$ & -0.008 & $0.007 * *$ & $0.007 * * *$ \\
\hline & $(0.028)$ & $(0.005)$ & $(0.016)$ & $(0.072)$ & $(0.063)$ & $(0.512)$ & $(0.016)$ & $(0.007)$ \\
\hline $\begin{array}{l}\text { \#Employers * Ind. } \\
\text { Homogeneity }\end{array}$ & & & $\begin{array}{l}0.054 * * \\
(0.039)\end{array}$ & & & & & \\
\hline \multicolumn{9}{|l|}{ Firm Characteristics } \\
\hline Pre-turnover Policy & $\begin{array}{c}-0.693 * * * \\
(0.000)\end{array}$ & $\begin{array}{c}-0.698 * * * \\
(0.000)\end{array}$ & $\begin{array}{c}-0.444 * * * \\
(0.000)\end{array}$ & $\begin{array}{c}-0.457 * * * \\
(0.000)\end{array}$ & $\begin{array}{c}-0.809 * * * \\
(0.000)\end{array}$ & $\begin{array}{c}-0.810 * * * \\
(0.000)\end{array}$ & $\begin{array}{c}-0.803^{* * *} \\
(0.000)\end{array}$ & $\begin{array}{c}-0.807 * * * \\
(0.000)\end{array}$ \\
\hline $\ln$ (Total Sales) & $\begin{array}{c}0.022 * * * \\
(0.000)\end{array}$ & $\begin{array}{c}-0.002 * * \\
(0.024)\end{array}$ & $\begin{array}{c}-0.002 * * \\
(0.043)\end{array}$ & $\begin{array}{l}0.001 * \\
(0.067)\end{array}$ & $\begin{array}{c}-0.018 * * * \\
(0.000)\end{array}$ & $\begin{array}{c}-0.030 * * * \\
(0.000)\end{array}$ & $\begin{array}{c}-0.019 * * * \\
(0.000)\end{array}$ & $\begin{array}{c}-0.018 * * * \\
(0.000)\end{array}$ \\
\hline Firm Age & $\begin{array}{l}-0.005 \\
(0.481)\end{array}$ & $\begin{array}{c}0.001 \\
(0.771)\end{array}$ & $\begin{array}{c}-0.003 * * \\
(0.011)\end{array}$ & $\begin{array}{c}0.001 \\
(0.344)\end{array}$ & $\begin{array}{c}-0.020 * * * \\
(0.000)\end{array}$ & $\begin{array}{c}-0.062 * * * \\
(0.000)\end{array}$ & $\begin{array}{c}-0.017 * * * \\
(0.000)\end{array}$ & $\begin{array}{c}-0.016 * * * \\
(0.000)\end{array}$ \\
\hline $\begin{array}{l}\text { Operating Return on } \\
\text { Assets }\end{array}$ & $\begin{array}{c}-0.575 * * * \\
(0.000)\end{array}$ & & & & $\begin{array}{c}-0.292 * * * \\
(0.000)\end{array}$ & $\begin{array}{c}-0.622 * * * \\
(0.000)\end{array}$ & $\begin{array}{c}-0.237 * * * \\
(0.000)\end{array}$ & $\begin{array}{c}-0.217 * * * \\
(0.000)\end{array}$ \\
\hline Surplus Cash & & $\begin{array}{l}0.020 * * \\
(0.018)\end{array}$ & $\begin{array}{c}0.120 * * * \\
(0.000)\end{array}$ & $\begin{array}{l}-0.011 \\
(0.251)\end{array}$ & & & & \\
\hline Tobin's Q & $\begin{array}{c}-0.022 * * * \\
(0.000)\end{array}$ & $\begin{array}{c}0.003 * * * \\
(0.002)\end{array}$ & $\begin{array}{l}-0.000 \\
(0.703)\end{array}$ & $\begin{array}{c}0.001 * * * \\
(0.008)\end{array}$ & $\begin{array}{l}0.008 * * * \\
(0.007)\end{array}$ & $\begin{array}{c}0.057 * * * \\
(0.000)\end{array}$ & $\begin{array}{c}0.005^{*} \\
(0.068)\end{array}$ & $\begin{array}{c}0.004 \\
(0.119)\end{array}$ \\
\hline R\&D/Total Assets & $\begin{array}{c}-0.356 * * * \\
(0.000)\end{array}$ & $\begin{array}{c}-0.039 * \\
(0.083)\end{array}$ & & $\begin{array}{c}0.005 \\
(0.764)\end{array}$ & $\begin{array}{c}0.476 * * * \\
(0.000)\end{array}$ & $\begin{array}{c}1.058 * * * \\
(0.000)\end{array}$ & $\begin{array}{c}0.414 * * * \\
(0.000)\end{array}$ & $\begin{array}{c}0.387^{* * *} \\
(0.000)\end{array}$ \\
\hline Adv./Total Assets & & $\begin{array}{c}0.017 \\
(0.635)\end{array}$ & $\begin{array}{c}-0.031 \\
(0.423)\end{array}$ & & $\begin{array}{c}0.154 \\
(0.171)\end{array}$ & $\begin{array}{l}-0.127 \\
(0.733)\end{array}$ & $\begin{array}{l}0.177 * \\
(0.098)\end{array}$ & $\begin{array}{l}0.183 * \\
(0.082)\end{array}$ \\
\hline CAPEXP & & & $\begin{array}{l}-0.005 \\
(0.773)\end{array}$ & $\begin{array}{c}0.017^{*} \\
(0.083)\end{array}$ & $\begin{array}{c}0.289 * * * \\
(0.000)\end{array}$ & $\begin{array}{c}0.559 * * * \\
(0.009)\end{array}$ & $\begin{array}{c}0.245 * * * \\
(0.000)\end{array}$ & $\begin{array}{c}0.227^{* * *} \\
(0.000)\end{array}$ \\
\hline Leverage & & $\begin{array}{c}-0.012 \\
(0.117)\end{array}$ & $\begin{array}{c}0.006 \\
(0.296)\end{array}$ & $\begin{array}{c}-0.006^{*} \\
(0.057)\end{array}$ & $\begin{array}{c}0.070 * * * \\
(0.001)\end{array}$ & $\begin{array}{c}0.051 \\
(0.492)\end{array}$ & $\begin{array}{c}0.075^{* * *} * \\
(0.000)\end{array}$ & $\begin{array}{c}0.075^{* * *} \\
(0.000)\end{array}$ \\
\hline Industry Homogeneity & & & $\begin{array}{c}-0.163 * * \\
(0.048)\end{array}$ & & & & & \\
\hline Capital Intensity & $\begin{array}{c}0.122 * * * \\
(0.000)\end{array}$ & & & & & & & \\
\hline Depr./Total Assets & $\begin{array}{l}-0.109 \\
(0.560)\end{array}$ & & & & & & & \\
\hline Pay Directors Equity & 0.011 & -0.001 & 0.002 & 0.002 & 0.009 & 0.004 & 0.008 & 0.008 \\
\hline Based Compensation & $(0.105)$ & $(0.779)$ & $(0.156)$ & $(0.107)$ & $(0.205)$ & $(0.873)$ & $(0.225)$ & $(0.203)$ \\
\hline
\end{tabular}


Table B.1.2 Continued

\begin{tabular}{|c|c|c|c|c|c|c|c|c|}
\hline \\
\hline \multicolumn{9}{|c|}{$\begin{array}{ll} & -0.246\end{array}$} \\
\hline Holding $(\%)$ & $(0.343)$ & $(0.342)$ & $(0.156)$ & $(0.747)$ & $(0.515)$ & $(0.029)$ & $(0.144)$ & $(0.121)$ \\
\hline$-0.003 \quad 0.007 * * * \quad 0.002 * *$ & $0.016^{* *}$ & -0.003 & $0.007 * * *$ & $0.002 * *$ & $-0.014 * *$ & $-0.100 * * *$ & -0.008 & -0.006 \\
\hline Compensation & $(0.034)$ & $(0.153)$ & $(0.001)$ & $(0.036)$ & $(0.040)$ & $(0.000)$ & $(0.159)$ & $(0.238)$ \\
\hline \multirow{2}{*}{$\begin{array}{l}\text { CEO Compensation } \\
\text { Delta }\end{array}$} & -0.007 & -0.001 & -0.000 & 0.001 & 0.002 & 0.022 & -0.000 & -0.000 \\
\hline & $(0.106)$ & $(0.371)$ & $(0.744)$ & $(0.221)$ & $(0.574)$ & $(0.185)$ & $(0.991)$ & $(0.882)$ \\
\hline \multirow{2}{*}{$\begin{array}{l}\text { CEO Compensation } \\
\text { Vega }\end{array}$} & $-0.018^{*}$ & -0.001 & 0.003 & -0.002 & -0.011 & $-0.075^{* *}$ & -0.010 & -0.009 \\
\hline & $(0.058)$ & $(0.771)$ & $(0.203)$ & $(0.261)$ & $(0.149)$ & $(0.018)$ & $(0.145)$ & $(0.183)$ \\
\hline \multirow[t]{2}{*}{ Herfindhal Index } & $0.356 * * *$ & -0.038 & -0.006 & 0.028 & $0.357 * * *$ & 0.397 & $0.310 * * *$ & $0.292 * * *$ \\
\hline & $(0.003)$ & $(0.319)$ & $(0.821)$ & $(0.202)$ & $(0.001)$ & $(0.361)$ & $(0.001)$ & $(0.002)$ \\
\hline \multicolumn{9}{|l|}{$\underline{\text { CEO Characteristics }}$} \\
\hline \multirow[t]{2}{*}{ Ln(CEO Tenure+1) } & 0.004 & $-0.004 * *$ & -0.000 & -0.001 & 0.001 & -0.003 & -0.002 & -0.002 \\
\hline & $(0.544)$ & $(0.015)$ & $(0.768)$ & $(0.131)$ & $(0.8$ & $(0$. & $(0.714)$ & $(0.619)$ \\
\hline \multirow[t]{2}{*}{ CEO Age } & $-0.083 * *$ & -0.011 & -0.012 & -0.004 & $-0.055 * *$ & 0.070 & $-0.056 * *$ & $-0.057 * *$ \\
\hline & $(0.013)$ & $(0.232)$ & $(0.107)$ & $(0.421)$ & $(0.032)$ & $(0.427)$ & $(0.018)$ & $(0.013)$ \\
\hline \multirow[t]{2}{*}{$\operatorname{MBA}(0 / 1)$} & $0.014 *$ & -0.002 & 0.002 & -0.001 & $-0.010^{*}$ & 0.004 & $-0.010^{*}$ & $-0.010 * *$ \\
\hline & $(0.075)$ & $(0.319)$ & $(0.211)$ & $(0.3$ & $(0.1$ & $(0$. & 6) & $(0.048)$ \\
\hline \multirow[t]{2}{*}{ Founder $(0 / 1)$} & 0.016 & -0.005 & -0.005 & -0.002 & $0.024 * *$ & 0.056 & $0.021 * *$ & $0.021 * *$ \\
\hline & $(0.270)$ & $(0.183)$ & $(0.168)$ & $(0.365)$ & $(0.032)$ & $(0.114)$ & $(0.032)$ & $(0.030)$ \\
\hline \multirow[t]{2}{*}{ \# Functional Areas } & -0.002 & -0.001 & 0.001 & -0.001 & 0.003 & 0.006 & 0.002 & 0.001 \\
\hline & $(0.556)$ & $(0.555)$ & $(0.382)$ & $(0.327)$ & $(0.369)$ & $(0.544)$ & $(0.512)$ & $(0.694)$ \\
\hline \multirow{2}{*}{$\begin{array}{l}\text { Has Finance } \\
\text { Background }(0 / 1)\end{array}$} & 0.010 & $-0.005^{*}$ & $-0.006^{* * *}$ & -0.001 & 0.001 & 0.001 & 0.001 & 0.001 \\
\hline & $(0.290)$ & $(0.099)$ & $(0.001)$ & $(0.437)$ & $(0.884)$ & $(0.977)$ & $(0.829)$ & $(0.856)$ \\
\hline \multirow[t]{2}{*}{ Constant } & $0.259^{*}$ & $0.131 * * *$ & $0.106^{* * *}$ & 0.008 & $0.615 * * *$ & $0.620^{*}$ & $0.612 * * *$ & $0.608 * * *$ \\
\hline & $(0.066)$ & $(0.000)$ & $(0.001)$ & $(0.682)$ & $(0.000)$ & $(0.087)$ & $(0.000)$ & $(0.000)$ \\
\hline Year Dummies & Yes & Yes & Yes & Yes & Yes & Yes & Yes & Yes \\
\hline Industry Dummies & Yes & Yes & Yes & Yes & Yes & Yes & Yes & Yes \\
\hline \multirow{2}{*}{$\begin{array}{l}\text { Observations } \\
\text { R-squared }\end{array}$} & 4826 & 5029 & 4914 & 5074 & 4693 & 4693 & 4693 & 4693 \\
\hline & 0.584 & 0.550 & 0.367 & 0.437 & 0.752 & 0.580 & 0.760 & 0.761 \\
\hline Hansen's J-test (p-value) & 0.57 & 0.858 & 0.379 & 0.632 & 0.139 & 0.892 & 0.136 & 0.166 \\
\hline $\begin{array}{l}\text { First Stage } F \text {-stat for } \\
\text { \#Employers }\end{array}$ & 51.18 & 55.57 & 40.65 & 47.88 & 63.45 & 76.44 & 62.49 & 62.57 \\
\hline \multicolumn{3}{|c|}{$\begin{array}{l}\text { First Stage F-stat for \#Employers * Industry } \\
\text { Homogeneity }\end{array}$} & 21.01 & & & & & \\
\hline
\end{tabular}




\section{Table B.1.3. Use Book Leverage as the Dependent Variable}

This table presents IV/2SLS results for the financing policy. The dependent variable is the Book Leverage. Refer to Table 1 and Appendix A for variable definitions. Pre-turnover Leverage is the firm's Leverage at the year before the year of CEO turnover. Instrumental variables are the unemployment rate for the year when the CEO started his first fulltime job, non-business career dummy that equals one if the CEO had academic or government jobs, and the number of years the CEO has worked in his current firm's industry. I report $p$-values of Hansen's J-test and first stage $F$-stat at the bottom of the table. The values of the five CEO employment history proxies in the IV/2SLS estimations are predicted values. The predicted signs for the CEO employment history proxies are presented in parenthesis at the beginning of each row. I report $p$-values based on robust standard errors clustered at the firm level in parenthesis. ${ }^{* *},{ }^{* *}$, and $*$ indicate significance at the 1,5 , and $10 \%$ levels, respectively.

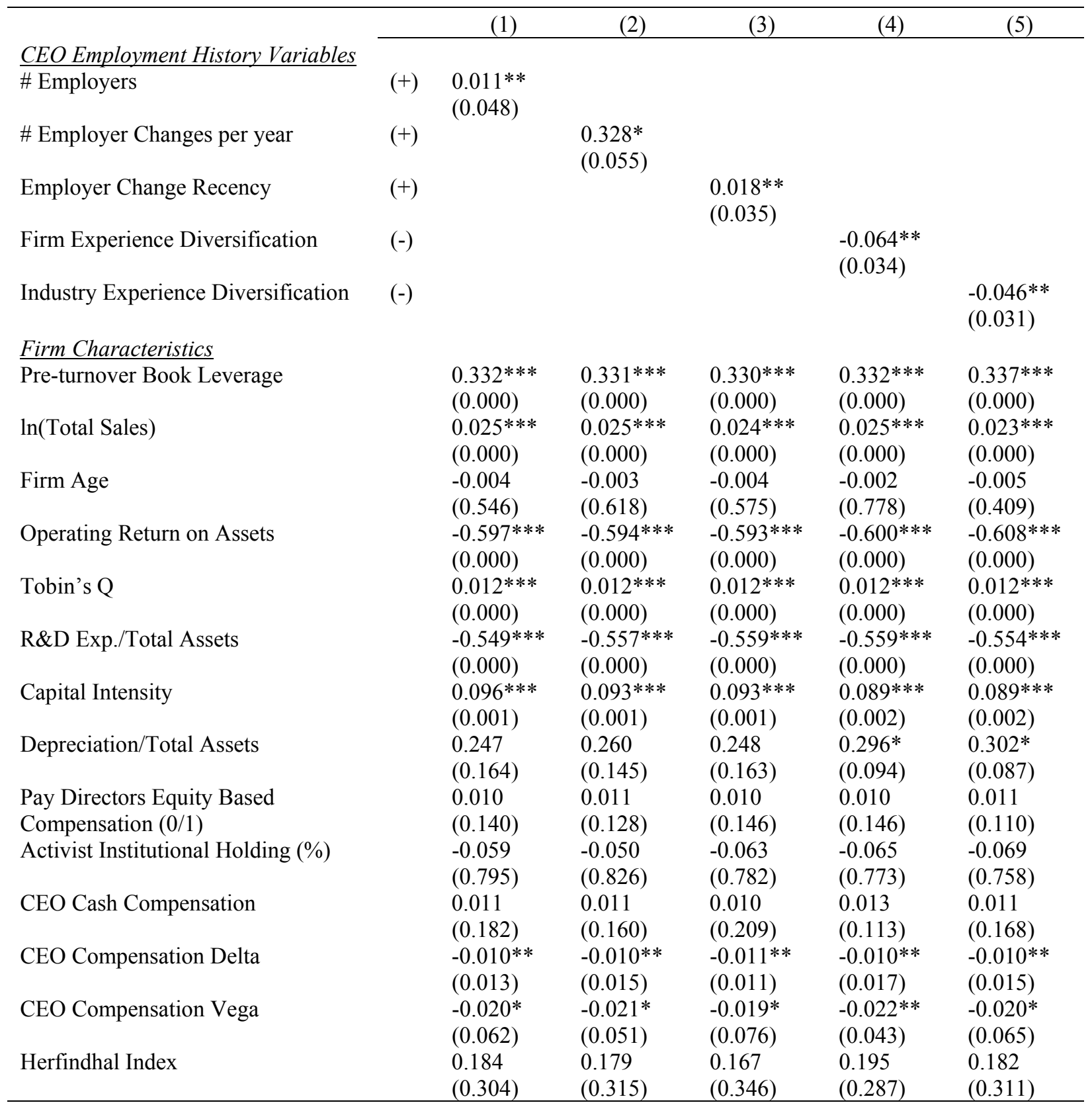


Table B.1.3 Continued.

\begin{tabular}{llllll}
\hline CEO Characteristics & & & & & \\
Ln(CEO Tenure+1) & 0.008 & 0.008 & 0.011 & 0.008 & 0.005 \\
CEO Age & $(0.203)$ & $(0.191)$ & $(0.109)$ & $(0.227)$ & $(0.380)$ \\
& -0.054 & -0.003 & -0.056 & -0.048 & -0.036 \\
MBA (0/1) & $(0.152)$ & $(0.936)$ & $(0.136)$ & $(0.176)$ & $(0.273)$ \\
& 0.002 & 0.002 & 0.004 & 0.002 & 0.004 \\
Founder (0/1) & $(0.767)$ & $(0.857)$ & $(0.646)$ & $(0.767)$ & $(0.652)$ \\
& 0.016 & 0.017 & 0.016 & 0.018 & 0.011 \\
\# Functional Areas & $(0.254)$ & $(0.248)$ & $(0.261)$ & $(0.205)$ & $(0.384)$ \\
& -0.002 & -0.002 & -0.001 & -0.001 & -0.001 \\
Had Finance Background (0/1) & $(0.578)$ & $(0.608)$ & $(0.712)$ & $(0.705)$ & $(0.729)$ \\
& $0.015^{*}$ & 0.014 & $0.015 *$ & $0.015^{*}$ & 0.013 \\
Constant & $(0.098)$ & $(0.113)$ & $(0.095)$ & $(0.098)$ & $(0.144)$ \\
& 0.095 & -0.108 & 0.118 & 0.127 & 0.099 \\
Year Dummies & $(0.524)$ & $(0.487)$ & $(0.439)$ & $(0.408)$ & $(0.501)$ \\
Industry Dummies & Yes & Yes & Yes & Yes & Yes \\
Observations & Yes & Yes & Yes & Yes & Yes \\
Adjusted R-squared & 5141 & 5141 & 5141 & 5141 & 5141 \\
& 0.501 & 0.500 & 0.498 & 0.502 & 0.507 \\
Hansen's J-test (p-value) & & & & & \\
First Stage Instrumental Variables' Joint & 50.971 & 0.242 & 0.365 & 0.36 & 0.354 \\
\end{tabular}




\section{Table B.1.4. CEO Employment History and the Intangibles Ratio}

This table presents IV/2SLS results for the firm's investments in intangibles. The dependent variable is the intangibles ratio which is the intangibles reported by the firm divided by total assets. Refer to Table 1 and Appendix A for variable definitions. Pre-turnover Intangibles Ratio is the firm's Intangible Ratio at the year before the year of CEO turnover. Instrumental variables are the unemployment rate for the year when the CEO started his first fulltime job, non-business career dummy that equals one if the CEO had academic or government jobs, and the number of years the CEO has worked in his current firm's industry. I report $p$-values of Hansen's J-test and first stage $F$-stat at the bottom of the table. The values of the five CEO employment history proxies in the IV/2SLS estimations are predicted values. The predicted signs for the CEO employment history proxies are presented in parenthesis at the beginning of each row. I report $p$-values based on robust standard errors clustered at the firm level in parenthesis. $* * *, * *$, and $*$ indicate significance at the 1,5 , and $10 \%$ levels, respectively.

\begin{tabular}{|c|c|c|c|c|c|c|}
\hline & & $(1)$ & $(2)$ & (3) & (4) & $(5)$ \\
\hline \multicolumn{7}{|l|}{ CEO Employment History Variables } \\
\hline \# Employers & $(+)$ & $\begin{array}{c}0.010 * * \\
(0.030)\end{array}$ & & & & \\
\hline \# Employer Changes per year & $(+)$ & & $\begin{array}{c}0.294 * * \\
(0.044)\end{array}$ & & & \\
\hline Employer Change Recency & $(+)$ & & & $\begin{array}{c}0.016 * * \\
(0.022)\end{array}$ & & \\
\hline Firm Experience Diversification & $(-)$ & & & & $\begin{array}{c}-0.057 * * \\
(0.024)\end{array}$ & \\
\hline Industry Experience Diversification & $(-)$ & & & & & $\begin{array}{c}-0.042 * * \\
(0.021)\end{array}$ \\
\hline \multicolumn{7}{|l|}{ Firm Characteristics } \\
\hline$\overline{\text { Pre-turnover Leverage }}$ & & $\begin{array}{c}0.518 * * * \\
(0.000)\end{array}$ & $\begin{array}{c}0.519 * * * \\
(0.000)\end{array}$ & $\begin{array}{c}0.518^{* * *} * \\
(0.000)\end{array}$ & $\begin{array}{c}0.516^{* * *} \\
(0.000)\end{array}$ & $\begin{array}{c}0.518 * * * \\
(0.000)\end{array}$ \\
\hline $\ln$ (Total Sales) & & $\begin{array}{c}-0.001 \\
(0.697)\end{array}$ & $\begin{array}{c}-0.001 \\
(0.704)\end{array}$ & $\begin{array}{c}-0.002 \\
(0.597)\end{array}$ & $\begin{array}{c}-0.001 \\
(0.721)\end{array}$ & $\begin{array}{l}-0.003 \\
(0.313)\end{array}$ \\
\hline Firm Age & & $\begin{array}{c}-0.002 \\
(0.734)\end{array}$ & $\begin{array}{l}-0.002 \\
(0.785)\end{array}$ & $\begin{array}{c}-0.002 \\
(0.766)\end{array}$ & $\begin{array}{l}-0.001 \\
(0.869)\end{array}$ & $\begin{array}{l}-0.003 \\
(0.642)\end{array}$ \\
\hline Operating Return on Assets & & $\begin{array}{c}0.072 * * \\
(0.022)\end{array}$ & $\begin{array}{c}0.074 * * \\
(0.018)\end{array}$ & $\begin{array}{c}0.073 * * \\
(0.022)\end{array}$ & $\begin{array}{c}0.068 * * \\
(0.032)\end{array}$ & $\begin{array}{l}0.062 * \\
(0.053)\end{array}$ \\
\hline Tobin's Q & & $\begin{array}{c}-0.015 * * * \\
(0.000)\end{array}$ & $\begin{array}{c}-0.015 * * * \\
(0.000)\end{array}$ & $\begin{array}{c}-0.015 * * * \\
(0.000)\end{array}$ & $\begin{array}{c}-0.015 * * * \\
(0.000)\end{array}$ & $\begin{array}{c}-0.015 * * * \\
(0.000)\end{array}$ \\
\hline R\&D Exp./Total Assets & & $\begin{array}{c}-0.358 * * * \\
(0.000)\end{array}$ & $\begin{array}{c}-0.362 * * * \\
(0.000)\end{array}$ & $\begin{array}{c}-0.365 * * * \\
(0.000)\end{array}$ & $\begin{array}{c}-0.354 * * * \\
(0.000)\end{array}$ & $\begin{array}{c}-0.343 * * * \\
(0.001)\end{array}$ \\
\hline Capital Intensity & & $\begin{array}{c}-0.331 * * \\
(0.015)\end{array}$ & $\begin{array}{c}-0.325^{* *} \\
(0.017)\end{array}$ & $\begin{array}{c}-0.322^{* *} \\
(0.021)\end{array}$ & $\begin{array}{c}-0.328^{* *} \\
(0.018)\end{array}$ & $\begin{array}{c}-0.324 * * \\
(0.021)\end{array}$ \\
\hline Depreciation/Total Assets & & $\begin{array}{c}-0.498 * * * \\
(0.000)\end{array}$ & $\begin{array}{c}-0.501 * * * \\
(0.000)\end{array}$ & $\begin{array}{c}-0.503 * * * \\
(0.000)\end{array}$ & $\begin{array}{c}-0.494 * * * \\
(0.000)\end{array}$ & $\begin{array}{c}-0.486 * * * \\
(0.000)\end{array}$ \\
\hline Pay Directors Equity Based & & $0.040 *$ & $0.039 *$ & $0.041 *$ & $0.043^{*}$ & $0.047 * *$ \\
\hline Compensation $(0 / 1)$ & & $(0.077)$ & $(0.083)$ & $(0.073)$ & $(0.054)$ & $(0.034)$ \\
\hline Activist Institutional Holding (\%) & & $\begin{array}{c}-0.004 \\
(0.514)\end{array}$ & $\begin{array}{c}-0.004 \\
(0.561)\end{array}$ & $\begin{array}{c}-0.004 \\
(0.530)\end{array}$ & $\begin{array}{c}-0.004 \\
(0.526)\end{array}$ & $\begin{array}{c}-0.004 \\
(0.551)\end{array}$ \\
\hline CEO Cash Compensation & & $\begin{array}{c}-0.004 \\
(0.984)\end{array}$ & $\begin{array}{c}0.007 \\
(0.970)\end{array}$ & $\begin{array}{c}-0.003 \\
(0.988)\end{array}$ & $\begin{array}{l}-0.013 \\
(0.947)\end{array}$ & $\begin{array}{l}-0.006 \\
(0.976)\end{array}$ \\
\hline CEO Compensation Delta & & $\begin{array}{c}-0.024 * * * \\
(0.002)\end{array}$ & $\begin{array}{c}-0.024 * * * \\
(0.002)\end{array}$ & $\begin{array}{c}-0.025 * * * \\
(0.002)\end{array}$ & $\begin{array}{c}-0.023 * * * \\
(0.003)\end{array}$ & $\begin{array}{c}-0.023 * * * \\
(0.003)\end{array}$ \\
\hline CEO Compensation Vega & & $\begin{array}{c}0.009 * * \\
(0.044)\end{array}$ & $\begin{array}{c}0.009 * * \\
(0.039)\end{array}$ & $\begin{array}{l}0.009 * \\
(0.052)\end{array}$ & $\begin{array}{c}0.010 * * \\
(0.037)\end{array}$ & $\begin{array}{c}0.009 * * \\
(0.045)\end{array}$ \\
\hline Herfindhal Index & & $\begin{array}{c}0.019 * \\
(0.085)\end{array}$ & $\begin{array}{c}0.018 \\
(0.103)\end{array}$ & $\begin{array}{c}0.020 * \\
(0.067)\end{array}$ & $\begin{array}{c}0.018 \\
(0.116)\end{array}$ & $\begin{array}{c}0.021 * \\
(0.064)\end{array}$ \\
\hline
\end{tabular}


Table B.1.4 Continued.

\begin{tabular}{|c|c|c|c|c|c|}
\hline \multicolumn{6}{|l|}{ CEO Characteristics } \\
\hline \multirow[t]{2}{*}{ Ln(CEO Tenure+1) } & $0.015 * * *$ & $0.015 * * *$ & $0.017 * * *$ & $0.014 * * *$ & $0.013 * *$ \\
\hline & $(0.006)$ & $(0.005)$ & $(0.003)$ & $(0.008)$ & $(0.018)$ \\
\hline \multirow[t]{2}{*}{ CEO Age } & $-0.079 * * *$ & -0.034 & $-0.082 * * *$ & $-0.072 * *$ & $-0.062 * *$ \\
\hline & $(0.006)$ & $(0.258)$ & $(0.005)$ & $(0.010)$ & $(0.023)$ \\
\hline \multirow[t]{2}{*}{$\operatorname{MBA}(0 / 1)$} & -0.010 & -0.010 & -0.009 & -0.010 & -0.009 \\
\hline & $(0.176)$ & $(0.158)$ & $(0.212)$ & $(0.183)$ & $(0.227)$ \\
\hline \multirow[t]{2}{*}{ Founder $(0 / 1)$} & -0.006 & -0.006 & -0.006 & -0.005 & -0.011 \\
\hline & $(0.613)$ & $(0.624)$ & $(0.620)$ & $(0.695)$ & $(0.338)$ \\
\hline \multirow[t]{2}{*}{ \# Functional Areas } & -0.001 & -0.001 & -0.001 & -0.001 & -0.001 \\
\hline & $(0.715)$ & $(0.754)$ & $(0.866)$ & $(0.793)$ & $(0.874)$ \\
\hline \multirow[t]{2}{*}{ Has Finance Background $(0 / 1)$} & -0.005 & -0.006 & -0.005 & -0.005 & -0.007 \\
\hline & $(0.547)$ & $(0.520)$ & $(0.545)$ & $(0.561)$ & $(0.429)$ \\
\hline \multirow[t]{2}{*}{ Constant } & $0.421 * * *$ & $0.240 *$ & $0.437 * * *$ & $0.444 * * *$ & $0.421 * * *$ \\
\hline & $(0.001)$ & $(0.094)$ & $(0.000)$ & $(0.000)$ & $(0.001)$ \\
\hline Year Dummies & Yes & Yes & Yes & Yes & Yes \\
\hline Industry Dummies & Yes & Yes & Yes & Yes & Yes \\
\hline Observations & 4208 & 4208 & 4208 & 4208 & 4208 \\
\hline Adjusted R-squared & 0.509 & 0.510 & 0.509 & 0.513 & 0.514 \\
\hline Hansen's J-test (p-value) & 0.469 & 0.35 & 0.544 & 0.512 & 0.529 \\
\hline First Stage Instrumental Variables' Joint & 47.3 & 49.36 & 56.94 & 82.15 & 263.36 \\
\hline
\end{tabular}


Table B.1.5: CEO Employment History and Four-factor Betas

This table presents IV/2SLS results for a firm's market risk for a sample of 4,693 firm years. The dependent variable in Panel A is the size beta from the 4-factor model, in Panel B is the book-to-market beta from the 4-factor model, and in Panel $\mathrm{C}$ is the momentum beta from the 4-factor model. Refer to Table 1 and Appendix A for variable definitions. Instrumental variables are the unemployment rate for the year when the CEO started his first fulltime job, non-business career dummy that equals one if the CEO had academic or government jobs, and the number of years the CEO has worked in his current firm's industry. Pre-turnover Betas are the firm's four-factor betas in the year before the CEO turnover year. I report p-values of Hansen's J-test and first stage $F$-stat at the bottom of the table. The values of the five CEO employment history proxies in the IV/2SLS estimations are predicted values. The predicted signs for the CEO employment history proxies are presented in parenthesis at the beginning of each row. I report $p$-values based on robust standard errors clustered at the firm level in parenthesis. ${ }^{* * *}, * *$, and $*$ indicate significance at the 1,5 , and $10 \%$ levels, respectively.

Panel A: The Size Beta from the Four Factor Model

\begin{tabular}{|c|c|c|c|c|c|c|}
\hline & & $(1)$ & (2) & (3) & (4) & $(5)$ \\
\hline \multicolumn{7}{|l|}{ CEO Employment History Variables } \\
\hline \# Employers & $(+)$ & $\begin{array}{c}-0.017 \\
(0.287)\end{array}$ & & & & \\
\hline \# Employer Changes per year & $(+)$ & & $\begin{array}{l}-0.508 \\
(0.333)\end{array}$ & & & \\
\hline Employer Change Recency & $(+)$ & & & $\begin{array}{l}-0.028 \\
(0.276)\end{array}$ & & \\
\hline Firm Experience Diversification & $(-)$ & & & & $\begin{array}{c}0.098 \\
(0.281)\end{array}$ & \\
\hline Industry Experience & $(-)$ & & & & & $\begin{array}{c}0.071 \\
(0.282)\end{array}$ \\
\hline \multicolumn{7}{|l|}{ Firm Characteristics } \\
\hline Pre-turnover Size Beta & & $\begin{array}{c}0.082^{* * *} \\
(0.000)\end{array}$ & $\begin{array}{c}0.083 * * * \\
(0.000)\end{array}$ & $\begin{array}{c}0.082^{* * * *} \\
(0.000)\end{array}$ & $\begin{array}{c}0.083 * * * \\
(0.000)\end{array}$ & $\begin{array}{c}0.082 * * * \\
(0.000)\end{array}$ \\
\hline $\ln$ (Total Sales) & & $\begin{array}{c}-0.215^{* * *} \\
(0.000)\end{array}$ & $\begin{array}{c}-0.215^{* * *} \\
(0.000)\end{array}$ & $\begin{array}{c}-0.215^{* * *} \\
(0.000)\end{array}$ & $\begin{array}{c}-0.215^{* * *} \\
(0.000)\end{array}$ & $\begin{array}{c}-0.212 * * * \\
(0.000)\end{array}$ \\
\hline Firm Age & & $\begin{array}{c}-0.047 * * \\
(0.035)\end{array}$ & $\begin{array}{c}-0.048 * * \\
(0.034)\end{array}$ & $\begin{array}{c}-0.047 * * \\
(0.035)\end{array}$ & $\begin{array}{c}-0.050 * * \\
(0.032)\end{array}$ & $\begin{array}{c}-0.046^{* *} \\
(0.038)\end{array}$ \\
\hline Tobin's Q & & $\begin{array}{c}-0.040 * * * \\
(0.001)\end{array}$ & $\begin{array}{c}-0.040 * * * \\
(0.001)\end{array}$ & $\begin{array}{c}-0.040 * * * \\
(0.001)\end{array}$ & $\begin{array}{c}-0.040^{* * *} \\
(0.001)\end{array}$ & $\begin{array}{c}-0.040 * * * \\
(0.001)\end{array}$ \\
\hline Operating Return on Assets & & $\begin{array}{c}-0.368^{* *} \\
(0.039)\end{array}$ & $\begin{array}{c}-0.373 * * \\
(0.036)\end{array}$ & $\begin{array}{c}-0.371 * * \\
(0.037)\end{array}$ & $\begin{array}{c}-0.372 * * \\
(0.036)\end{array}$ & $\begin{array}{c}-0.362 * * \\
(0.040)\end{array}$ \\
\hline R\&D Exp./Total Assets & & $\begin{array}{c}0.120 \\
(0.774)\end{array}$ & $\begin{array}{c}0.128 \\
(0.760)\end{array}$ & $\begin{array}{c}0.130 \\
(0.757)\end{array}$ & $\begin{array}{c}0.110 \\
(0.794)\end{array}$ & $\begin{array}{c}0.104 \\
(0.804)\end{array}$ \\
\hline Advertising/Total Assets & & $\begin{array}{c}0.465 \\
(0.395)\end{array}$ & $\begin{array}{c}0.449 \\
(0.406)\end{array}$ & $\begin{array}{c}0.469 \\
(0.389)\end{array}$ & $\begin{array}{c}0.481 \\
(0.377)\end{array}$ & $\begin{array}{c}0.455 \\
(0.402)\end{array}$ \\
\hline CAPEXP/Total Assets & & $\begin{array}{l}-0.045 \\
(0.869)\end{array}$ & $\begin{array}{l}-0.038 \\
(0.890)\end{array}$ & $\begin{array}{l}-0.042 \\
(0.879)\end{array}$ & $\begin{array}{l}-0.053 \\
(0.848)\end{array}$ & $\begin{array}{l}-0.063 \\
(0.821)\end{array}$ \\
\hline Leverage & & $\begin{array}{c}0.308 * * * \\
(0.001)\end{array}$ & $\begin{array}{c}0.307 * * * \\
(0.001)\end{array}$ & $\begin{array}{c}0.307 * * * \\
(0.000)\end{array}$ & $\begin{array}{c}0.304 * * * \\
(0.001)\end{array}$ & $\begin{array}{c}0.298 * * * \\
(0.001)\end{array}$ \\
\hline $\begin{array}{l}\text { Pay Directors Equity Based } \\
\text { Compensation }(0 / 1)\end{array}$ & & $\begin{array}{c}0.004 \\
(0.899)\end{array}$ & $\begin{array}{c}0.003 \\
(0.914)\end{array}$ & $\begin{array}{c}0.004 \\
(0.896)\end{array}$ & $\begin{array}{c}0.003 \\
(0.911)\end{array}$ & $\begin{array}{c}0.003 \\
(0.930)\end{array}$ \\
\hline Activist Institutional Holding (\%) & & $\begin{array}{c}0.679 \\
(0.391)\end{array}$ & $\begin{array}{c}0.668 \\
(0.397)\end{array}$ & $\begin{array}{c}0.679 \\
(0.392)\end{array}$ & $\begin{array}{c}0.666 \\
(0.401)\end{array}$ & $\begin{array}{c}0.661 \\
(0.404)\end{array}$ \\
\hline CEO Cash Compensation & & $\begin{array}{c}0.038 \\
(0.205)\end{array}$ & $\begin{array}{c}0.037 \\
(0.223)\end{array}$ & $\begin{array}{c}0.039 \\
(0.198)\end{array}$ & $\begin{array}{c}0.035 \\
(0.247)\end{array}$ & $\begin{array}{c}0.038 \\
(0.207)\end{array}$ \\
\hline CEO Compensation Delta & & $\begin{array}{l}-0.016 \\
(0.274)\end{array}$ & $\begin{array}{l}-0.016 \\
(0.260)\end{array}$ & $\begin{array}{l}-0.015 \\
(0.288)\end{array}$ & $\begin{array}{l}-0.017 \\
(0.250)\end{array}$ & $\begin{array}{l}-0.016 \\
(0.255)\end{array}$ \\
\hline CEO Compensation Vega & & $\begin{array}{c}-0.091 * * * \\
(0.006)\end{array}$ & $\begin{array}{c}-0.090 * * * \\
(0.008)\end{array}$ & $\begin{array}{c}-0.093 * * * \\
(0.005)\end{array}$ & $\begin{array}{c}-0.089 * * * \\
(0.008)\end{array}$ & $\begin{array}{c}-0.093 * * * \\
(0.005)\end{array}$ \\
\hline Herfindhal Index & & $\begin{array}{c}0.288 \\
(0.553)\end{array}$ & $\begin{array}{c}0.295 \\
(0.544)\end{array}$ & $\begin{array}{c}0.293 \\
(0.544)\end{array}$ & $\begin{array}{c}0.272 \\
(0.574)\end{array}$ & $\begin{array}{c}0.302 \\
(0.533)\end{array}$ \\
\hline
\end{tabular}


Table 15 Continued.

\begin{tabular}{lccccc}
\hline CEO Characteristics & & & & & \\
Ln(CEO Tenure+1) & 0.006 & 0.005 & 0.001 & 0.007 & 0.010 \\
CEO Age & $(0.770)$ & $(0.787)$ & $(0.948)$ & $(0.702)$ & $(0.606)$ \\
& 0.165 & 0.086 & 0.167 & 0.153 & 0.138 \\
MBA (0/1) & $(0.116)$ & $(0.450)$ & $(0.112)$ & $(0.138)$ & $(0.175)$ \\
& -0.002 & -0.001 & -0.004 & -0.002 & -0.003 \\
Founder (0/1) & $(0.938)$ & $(0.975)$ & $(0.876)$ & $(0.932)$ & $(0.887)$ \\
& -0.001 & -0.000 & 0.000 & -0.003 & 0.009 \\
\# Functional Areas & $(0.983)$ & $(0.995)$ & $(0.995)$ & $(0.943)$ & $(0.832)$ \\
& 0.018 & 0.018 & 0.017 & 0.017 & 0.017 \\
Has Finance Background (0/1) & $(0.144)$ & $(0.149)$ & $(0.169)$ & $(0.167)$ & $(0.172)$ \\
& -0.039 & -0.039 & -0.040 & -0.040 & -0.037 \\
Constant & $(0.159)$ & $(0.167)$ & $(0.152)$ & $(0.155)$ & $(0.188)$ \\
& $1.514 * * *$ & $1.823 * * *$ & $1.489 * * *$ & $1.481 * * *$ & $1.505 * * *$ \\
Year Dummies & $(0.001)$ & $(0.001)$ & $(0.001)$ & $(0.001)$ & $(0.001)$ \\
& Yes & Yes & Yes & Yes & Yes \\
Observations & Yes & Yes & Yes & Yes & Yes \\
Adjusted R-squared & 4693 & 4693 & 4693 & 4693 & 4693 \\
& 0.458 & 0.458 & 0.459 & 0.459 & 0.459 \\
Hansen's J-test (p-value) & & & & & \\
First Stage Instrumental Variables' Joint & 0.847 & 0.767 & 0.866 & 0.858 & 0.853 \\
Significance (F-stat) & & & & & \\
\hline
\end{tabular}

Panel B: The Book-to-Market Beta from the Four-Factor Model

\begin{tabular}{|c|c|c|c|c|c|c|}
\hline & & $(1)$ & $(2)$ & $(3)$ & $(4)$ & $(5)$ \\
\hline \multicolumn{7}{|c|}{ CEO Employment History Variables } \\
\hline \# Employers & $(+)$ & $\begin{array}{l}0.032 * \\
(0.083)\end{array}$ & & & & \\
\hline \# Employer Changes per year & $(+)$ & & $\begin{array}{l}1.098^{*} \\
(0.062)\end{array}$ & & & \\
\hline Employer Change Recency & $(+)$ & & & $\begin{array}{c}0.047 \\
(0.110)\end{array}$ & & \\
\hline Firm Experience Diversification & $(-)$ & & & & $\begin{array}{l}-0.162 \\
(0.124)\end{array}$ & \\
\hline Industry Experience & $(-)$ & & & & & $\begin{array}{l}-0.120 \\
(0.115)\end{array}$ \\
\hline \multicolumn{7}{|l|}{ Firm Characteristics } \\
\hline$\overline{\text { Pre-turnover Market Risk }}$ & & $\begin{array}{c}0.123 * * * \\
(0.000)\end{array}$ & $\begin{array}{c}0.123 * * * \\
(0.000)\end{array}$ & $\begin{array}{c}0.124 * * * \\
(0.000)\end{array}$ & $\begin{array}{c}0.122 * * * \\
(0.000)\end{array}$ & $\begin{array}{c}0.123 * * * \\
(0.000)\end{array}$ \\
\hline $\ln$ (Total Sales) & & $\begin{array}{c}-0.044 * * * \\
(0.002)\end{array}$ & $\begin{array}{c}-0.043 * * * \\
(0.003)\end{array}$ & $\begin{array}{c}-0.046^{* * * *} \\
(0.001)\end{array}$ & $\begin{array}{c}-0.046^{* * * *} \\
(0.001)\end{array}$ & $\begin{array}{c}-0.051^{* * *} \\
(0.000)\end{array}$ \\
\hline Firm Age & & $\begin{array}{c}0.095^{* * *} \\
(0.000)\end{array}$ & $\begin{array}{c}0.098^{* * *} * \\
(0.000)\end{array}$ & $\begin{array}{c}0.094 * * * \\
(0.000)\end{array}$ & $\begin{array}{c}0.099 * * * \\
(0.000)\end{array}$ & $\begin{array}{c}0.092 * * * \\
(0.000)\end{array}$ \\
\hline Tobin's Q & & $\begin{array}{c}-0.084 * * * \\
(0.000)\end{array}$ & $\begin{array}{c}-0.084 * * * \\
(0.000)\end{array}$ & $\begin{array}{c}-0.085^{* * * *} \\
(0.000)\end{array}$ & $\begin{array}{c}-0.086^{* * * *} \\
(0.000)\end{array}$ & $\begin{array}{c}-0.085^{* * *} \\
(0.000)\end{array}$ \\
\hline Operating Return on Assets & & $\begin{array}{l}-0.132 \\
(0.543)\end{array}$ & $\begin{array}{l}-0.122 \\
(0.572)\end{array}$ & $\begin{array}{l}-0.125 \\
(0.563)\end{array}$ & $\begin{array}{l}-0.122 \\
(0.571)\end{array}$ & $\begin{array}{c}-0.141 \\
(0.514)\end{array}$ \\
\hline R\&D Exp./Total Assets & & $\begin{array}{c}-2.598 * * * \\
(0.000)\end{array}$ & $\begin{array}{c}-2.619 * * * \\
(0.000)\end{array}$ & $\begin{array}{c}-2.610^{* * * *} \\
(0.000)\end{array}$ & $\begin{array}{c}-2.583 * * * \\
(0.000)\end{array}$ & $\begin{array}{c}-2.569 * * * \\
(0.000) \\
\end{array}$ \\
\hline
\end{tabular}


Table B.1.5 Continued

\begin{tabular}{|c|c|c|c|c|c|}
\hline \multicolumn{6}{|c|}{ Firm Characteristics (Continued) } \\
\hline \multirow[t]{2}{*}{ Advertising/Total Assets } & -0.694 & -0.673 & -0.694 & -0.712 & -0.672 \\
\hline & $(0.132)$ & $(0.146)$ & $(0.137)$ & $(0.128)$ & $(0.140)$ \\
\hline \multirow[t]{2}{*}{ CAPEXP/Total Assets } & -0.641 & -0.647 & $-0.652 *$ & -0.634 & -0.617 \\
\hline & $(0.110)$ & $(0.107)$ & $(0.099)$ & $(0.107)$ & $(0.117)$ \\
\hline \multirow[t]{2}{*}{ Leverage } & $0.281 * * *$ & $0.278 * * *$ & $0.285 * * *$ & $0.293 * * *$ & $0.302 * * *$ \\
\hline & $(0.007)$ & $(0.008)$ & $(0.006)$ & $(0.004)$ & $(0.002)$ \\
\hline Pay Directors Equity Based & -0.005 & -0.005 & -0.005 & -0.004 & -0.003 \\
\hline Compensation $(0 / 1)$ & $(0.877)$ & $(0.880)$ & $(0.886)$ & $(0.906)$ & $(0.934)$ \\
\hline \multirow[t]{2}{*}{ Activist Institutional Holding (\%) } & $1.800^{*}$ & $1.814^{*}$ & $1.806^{*}$ & $1.825^{*}$ & $1.836^{*}$ \\
\hline & $(0.084)$ & $(0.082)$ & $(0.080)$ & $(0.078)$ & $(0.074)$ \\
\hline \multirow[t]{2}{*}{ CEO Cash Compensation } & 0.034 & 0.037 & 0.034 & 0.040 & 0.035 \\
\hline & $(0.396)$ & $(0.358)$ & $(0.402)$ & $(0.321)$ & $(0.380)$ \\
\hline \multirow[t]{2}{*}{ CEO Compensation Delta } & -0.000 & 0.001 & -0.001 & 0.001 & 0.001 \\
\hline & $(0.984)$ & $(0.969)$ & $(0.933)$ & $(0.951)$ & $(0.964)$ \\
\hline \multirow[t]{2}{*}{ CEO Compensation Vega } & $-0.069^{*}$ & $-0.075^{*}$ & $-0.066^{*}$ & $-0.072 *$ & $-0.066^{*}$ \\
\hline & $(0.078)$ & $(0.064)$ & $(0.093)$ & $(0.073)$ & $(0.086)$ \\
\hline \multirow{2}{*}{ Herfindhal Index } & 0.466 & 0.456 & 0.455 & 0.487 & 0.438 \\
\hline & $(0.541)$ & $(0.549)$ & $(0.553)$ & $(0.520)$ & $(0.564)$ \\
\hline \multicolumn{6}{|l|}{ CEO Characteristics } \\
\hline \multirow[t]{2}{*}{ Ln(CEO Tenure+1) } & 0.003 & 0.006 & 0.010 & -0.001 & -0.005 \\
\hline & $(0.894)$ & $(0.814)$ & $(0.708)$ & $(0.969)$ & $(0.843)$ \\
\hline \multirow[t]{2}{*}{ CEO Age } & $0.386 * * *$ & $0.542 * * *$ & $0.391 * * *$ & $0.415 * * *$ & $0.441 * * *$ \\
\hline & $(0.003)$ & $(0.000)$ & $(0.002)$ & $(0.001)$ & $(0.000)$ \\
\hline \multirow[t]{2}{*}{$\operatorname{MBA}(0 / 1)$} & 0.021 & 0.017 & 0.025 & 0.022 & 0.024 \\
\hline & $(0.471)$ & $(0.564)$ & $(0.388)$ & $(0.434)$ & $(0.389)$ \\
\hline \multirow[t]{2}{*}{ Founder $(0 / 1)$} & 0.004 & 0.008 & -0.002 & 0.003 & -0.017 \\
\hline & $(0.941)$ & $(0.865)$ & $(0.972)$ & $(0.953)$ & $(0.718)$ \\
\hline \multirow[t]{2}{*}{ \# Functional Areas } & 0.000 & 0.000 & 0.003 & 0.003 & 0.003 \\
\hline & $(0.973)$ & $(0.981)$ & $(0.823)$ & $(0.824)$ & $(0.807)$ \\
\hline \multirow[t]{2}{*}{ Has Finance Background (0/1) } & $0.056^{*}$ & $0.054^{*}$ & $0.057 *$ & $0.057 *$ & 0.053 \\
\hline & $(0.086)$ & $(0.097)$ & $(0.079)$ & $(0.076)$ & $(0.105)$ \\
\hline \multirow[t]{2}{*}{ Constant } & $-1.291 * *$ & $-1.940 * * *$ & $-1.261 * *$ & $-1.248 * *$ & $-1.284 * *$ \\
\hline & $(0.039)$ & $(0.004)$ & $(0.048)$ & $(0.047)$ & $(0.039)$ \\
\hline \multirow[t]{2}{*}{ Year Dummies } & Yes & Yes & Yes & Yes & Yes \\
\hline & Yes & Yes & Yes & Yes & Yes \\
\hline Observations & 4693 & 4693 & 4693 & 4693 & 4693 \\
\hline Adjusted R-squared & 0.369 & 0.368 & 0.370 & 0.372 & 0.374 \\
\hline Hansen's J-test (p-value) & 0.414 & 0.504 & 0.343 & 0.304 & 0.309 \\
\hline \multicolumn{6}{|l|}{ First Stage Instrumental Variables' Joint } \\
\hline Significance (F-stat) & 54.83 & 55.40 & 59.02 & 90.60 & 270.37 \\
\hline
\end{tabular}




\begin{tabular}{|c|c|c|c|c|c|c|}
\hline & & (1) & (2) & (3) & (4) & $(5)$ \\
\hline \multicolumn{7}{|l|}{$\underline{\text { CEO Employment History Variables }}$} \\
\hline \# Employers & $(+)$ & $\begin{array}{c}0.010 \\
(0.408)\end{array}$ & & & & \\
\hline \# Employer Changes per year & $(+)$ & & $\begin{array}{c}0.351 \\
(0.377)\end{array}$ & & & \\
\hline Employer Change Recency & $(+)$ & & & $\begin{array}{c}0.019 \\
(0.332)\end{array}$ & & \\
\hline Firm Experience Diversification & $(-)$ & & & & $\begin{array}{l}-0.074 \\
(0.284)\end{array}$ & \\
\hline Industry Experience & $(-)$ & & & & & $\begin{array}{l}-0.053 \\
(0.295)\end{array}$ \\
\hline \multicolumn{7}{|l|}{$\underline{\text { Firm Characteristics }}$} \\
\hline$\overline{\text { Pre-turnover Market Risk }}$ & & $\begin{array}{c}0.017 \\
(0.275)\end{array}$ & $\begin{array}{c}0.017 \\
(0.271)\end{array}$ & $\begin{array}{c}0.017 \\
(0.270)\end{array}$ & $\begin{array}{c}0.017 \\
(0.275)\end{array}$ & $\begin{array}{c}0.016 \\
(0.299)\end{array}$ \\
\hline $\ln$ (Total Sales) & & $\begin{array}{c}0.007 \\
(0.455)\end{array}$ & $\begin{array}{c}0.008 \\
(0.438)\end{array}$ & $\begin{array}{c}0.007 \\
(0.447)\end{array}$ & $\begin{array}{c}0.008 \\
(0.415)\end{array}$ & $\begin{array}{c}0.006 \\
(0.539)\end{array}$ \\
\hline \multicolumn{7}{|l|}{ Firm Characteristics Continued } \\
\hline Firm Age & & $\begin{array}{c}0.001 \\
(0.954)\end{array}$ & $\begin{array}{c}0.002 \\
(0.905)\end{array}$ & $\begin{array}{c}0.001 \\
(0.930)\end{array}$ & $\begin{array}{c}0.004 \\
(0.808)\end{array}$ & $\begin{array}{c}0.001 \\
(0.965)\end{array}$ \\
\hline Tobin's Q & & $\begin{array}{c}0.041 * * * \\
(0.001)\end{array}$ & $\begin{array}{c}0.041 * * * \\
(0.001)\end{array}$ & $\begin{array}{c}0.041 * * * \\
(0.001)\end{array}$ & $\begin{array}{c}0.040 * * * \\
(0.001)\end{array}$ & $\begin{array}{c}0.041 * * * \\
(0.001)\end{array}$ \\
\hline Operating Return on Assets & & $\begin{array}{c}1.279 * * * \\
(0.000)\end{array}$ & $\begin{array}{c}1.282 * * * \\
(0.000)\end{array}$ & $\begin{array}{c}1.280 * * * \\
(0.000)\end{array}$ & $\begin{array}{c}1.281 * * * \\
(0.000)\end{array}$ & $\begin{array}{c}1.273 * * * \\
(0.000)\end{array}$ \\
\hline R\&D Exp./Total Assets & & $\begin{array}{c}-0.805 * * * \\
(0.003)\end{array}$ & $\begin{array}{c}-0.811 * * * \\
(0.003)\end{array}$ & $\begin{array}{c}-0.812 * * * \\
(0.003)\end{array}$ & $\begin{array}{c}-0.798 * * * \\
(0.003)\end{array}$ & $\begin{array}{c}-0.794 * * * \\
(0.004)\end{array}$ \\
\hline Advertising/Total Assets & & $\begin{array}{c}-1.118 * * * \\
(0.001)\end{array}$ & $\begin{array}{c}-1.111 * * * \\
(0.001)\end{array}$ & $\begin{array}{c}-1.124 * * * \\
(0.001)\end{array}$ & $\begin{array}{c}-1.137 * * * \\
(0.001)\end{array}$ & $\begin{array}{c}-1.120 * * * \\
(0.001)\end{array}$ \\
\hline CAPEXP/Total Assets & & $\begin{array}{l}-0.023 \\
(0.942)\end{array}$ & $\begin{array}{l}-0.025 \\
(0.937)\end{array}$ & $\begin{array}{c}-0.023 \\
(0.942)\end{array}$ & $\begin{array}{l}-0.012 \\
(0.970)\end{array}$ & $\begin{array}{l}-0.004 \\
(0.991)\end{array}$ \\
\hline Leverage & & $\begin{array}{c}-0.176^{* *} \\
(0.026)\end{array}$ & $\begin{array}{c}-0.177^{* *} \\
(0.025)\end{array}$ & $\begin{array}{c}-0.177^{* *} \\
(0.025)\end{array}$ & $\begin{array}{c}-0.176^{* *} \\
(0.025)\end{array}$ & $\begin{array}{c}-0.171^{* *} \\
(0.028)\end{array}$ \\
\hline $\begin{array}{l}\text { Pay Directors Equity Based } \\
\text { Compensation }(0 / 1)\end{array}$ & & $\begin{array}{c}0.007 \\
(0.794)\end{array}$ & $\begin{array}{c}0.007 \\
(0.793)\end{array}$ & $\begin{array}{c}0.006 \\
(0.803)\end{array}$ & $\begin{array}{c}0.006 \\
(0.800)\end{array}$ & $\begin{array}{c}0.007 \\
(0.784)\end{array}$ \\
\hline Activist Institutional Holding (\%) & & $\begin{array}{c}-2.355^{* * *} \\
(0.004)\end{array}$ & $\begin{array}{c}-2.350^{* * *} \\
(0.004)\end{array}$ & $\begin{array}{c}-2.358^{* * *} \\
(0.004)\end{array}$ & $\begin{array}{c}-2.351^{* * *} \\
(0.004)\end{array}$ & $\begin{array}{c}-2.348^{* * *} \\
(0.004)\end{array}$ \\
\hline CEO Cash Compensation & & $\begin{array}{c}-0.201 * * * \\
(0.000)\end{array}$ & $\begin{array}{c}-0.200^{* * *} \\
(0.000)\end{array}$ & $\begin{array}{c}-0.201 * * * \\
(0.000)\end{array}$ & $\begin{array}{c}-0.199 * * * \\
(0.000)\end{array}$ & $\begin{array}{r}-0.201 * * * \\
(0.000)\end{array}$ \\
\hline CEO Compensation Delta & & $\begin{array}{c}0.019 \\
(0.102)\end{array}$ & $\begin{array}{l}0.019^{*} \\
(0.096)\end{array}$ & $\begin{array}{c}0.018 \\
(0.110)\end{array}$ & $\begin{array}{l}0.019^{*} \\
(0.090)\end{array}$ & $\begin{array}{l}0.019^{*} \\
(0.098)\end{array}$ \\
\hline CEO Compensation Vega & & $\begin{array}{l}-0.028 \\
(0.347)\end{array}$ & $\begin{array}{l}-0.030 \\
(0.322)\end{array}$ & $\begin{array}{l}-0.027 \\
(0.352)\end{array}$ & $\begin{array}{l}-0.030 \\
(0.310)\end{array}$ & $\begin{array}{l}-0.028 \\
(0.348)\end{array}$ \\
\hline Herfindhal Index & & $\begin{array}{l}-0.573 \\
(0.295)\end{array}$ & $\begin{array}{l}-0.576 \\
(0.292)\end{array}$ & $\begin{array}{l}-0.575 \\
(0.292)\end{array}$ & $\begin{array}{l}-0.559 \\
(0.310)\end{array}$ & $\begin{array}{l}-0.581 \\
(0.290)\end{array}$ \\
\hline$\underline{\text { CEO Characteristics }}$ & & & & & & \\
\hline $\mathrm{Ln}(\mathrm{CEO}$ Tenure +1$)$ & & $\begin{array}{l}-0.027 * \\
(0.097)\end{array}$ & $\begin{array}{l}-0.026 \\
(0.113)\end{array}$ & $\begin{array}{l}-0.023 \\
(0.171)\end{array}$ & $\begin{array}{l}-0.027 * \\
(0.087)\end{array}$ & $\begin{array}{l}-0.029 * \\
(0.066)\end{array}$ \\
\hline CEO Age & & $\begin{array}{c}0.096 \\
(0.293)\end{array}$ & $\begin{array}{c}0.146 \\
(0.106)\end{array}$ & $\begin{array}{c}0.091 \\
(0.316)\end{array}$ & $\begin{array}{c}0.098 \\
(0.269)\end{array}$ & $\begin{array}{c}0.109 \\
(0.210)\end{array}$ \\
\hline $\operatorname{MBA}(0 / 1)$ & & $\begin{array}{l}-0.008 \\
(0.699)\end{array}$ & $\begin{array}{l}-0.009 \\
(0.655)\end{array}$ & $\begin{array}{l}-0.007 \\
(0.721)\end{array}$ & $\begin{array}{l}-0.008 \\
(0.668)\end{array}$ & $\begin{array}{l}-0.007 \\
(0.706)\end{array}$ \\
\hline Founder $(0 / 1)$ & & $\begin{array}{c}0.068^{* *} \\
(0.040)\end{array}$ & $\begin{array}{c}0.069^{* *} \\
(0.035)\end{array}$ & $\begin{array}{c}0.069 * * \\
(0.036)\end{array}$ & $\begin{array}{c}0.073^{* *} \\
(0.031)\end{array}$ & $\begin{array}{c}0.064^{* *} \\
(0.039) \\
\end{array}$ \\
\hline
\end{tabular}


Table B.1.5.Continued

\begin{tabular}{lccccc}
\hline CEO Characteristics (Continued) & & & & & \\
\# Functional Areas & -0.011 & -0.011 & -0.011 & -0.011 & -0.011 \\
& $(0.239)$ & $(0.236)$ & $(0.261)$ & $(0.255)$ & $(0.261)$ \\
Has Finance Background (0/1) & $0.075^{* * *}$ & $0.074^{* * *}$ & $0.075^{* * *}$ & $0.075^{* * *}$ & $0.073^{* * *}$ \\
& $(0.001)$ & $(0.001)$ & $(0.001)$ & $(0.001)$ & $(0.001)$ \\
Constant & -0.282 & -0.490 & -0.263 & -0.245 & -0.260 \\
& $(0.420)$ & $(0.220)$ & $(0.456)$ & $(0.488)$ & $(0.461)$ \\
Year Dummies & Yes & Yes & Yes & Yes & Yes \\
Industry Dummies & Yes & Yes & Yes & Yes & Yes \\
Observations & 4693 & 4693 & 4693 & 4693 & 4693 \\
Adjusted R-squared & 0.191 & 0.191 & 0.192 & 0.191 & 0.191 \\
& & & & & \\
Hansen's J-test (p-value) & 0.312 & 0.338 & 0.336 & 0.362 & 0.357 \\
First Stage Instrumental Variables' Joint & & & & & \\
Significance (F-stat) & 54.39 & 55.17 & 58.16 & 90.96 & 269.95 \\
\hline
\end{tabular}


Table B.1.6: CEO Employment History in the Year of Turnover

This table presents IV/2SLS results for firm policies and risk when CEO Employment History is measured in the year of turnover. The CEO Employment History variables stay constant for post-turnover years. The dependent variables are listed at the top of each column. Refer to Table 1 and Appendix A for variable definitions. Pre-turnover firm policies are the respective firm policies in the year before the CEO turnover year. Instrumental variables for \#Employers are the unemployment rate for the year when the CEO started his first fulltime job, non-business career dummy that equals one if the $\mathrm{CEO}$ had academic or government jobs, and the number of years the $\mathrm{CEO}$ has worked in his current firm's industry. The instrumental variable for CEO employment history*Industry Homogeneity in the $\mathrm{R} \& \mathrm{D}$ regression is the unemployment rate described above multiplied by industry homogeneity. The predicted signs for the CEO employment history proxies are presented in parenthesis at the top of each column. I report $p$-values based on robust standard errors clustered at the firm level in parenthesis.***, **, and * indicate significance at the 1 , 5 , and $10 \%$ levels, respectively.

Panel A: CEO Employment History Proxy: \#Employers per year

\begin{tabular}{|c|c|c|c|c|c|c|c|c|}
\hline & Leverage & CAPEXP & $R \& D$ & Adv. & $\begin{array}{c}\text { Total Risk } \\
\text { (Daily } \\
\text { Stock } \\
\text { Return Std.) }\end{array}$ & $\begin{array}{l}\text { Market } \\
\text { Risk } \\
\text { (CAPM) }\end{array}$ & $\begin{array}{c}\text { Firm- } \\
\text { specific } \\
\text { Risk } \\
\text { (CAPM) }\end{array}$ & $\begin{array}{c}\text { Firm- } \\
\text { specific } \\
\text { Risk } \\
\text { (4- Factor) }\end{array}$ \\
\hline & $\theta+$ & $(-)$ & $(+)$ & $(+)$ & $(+)$ & $(+)$ & $(+)$ & $(+)$ \\
\hline \#Employers & $\begin{array}{l}0.305^{* *} \\
(0.024)\end{array}$ & $\begin{array}{c}-0.086^{* *} \\
(0.010)\end{array}$ & $\begin{array}{l}-0.094 * \\
(0.094)\end{array}$ & $\begin{array}{l}0.028^{*} \\
(0.092)\end{array}$ & $\begin{array}{l}0.141^{*} \\
(0.085)\end{array}$ & $\begin{array}{l}-0.216 \\
(0.470)\end{array}$ & $\begin{array}{r}0.179^{* *} \\
(0.019)\end{array}$ & $\begin{array}{c}0.193 * * * \\
(0.009)\end{array}$ \\
\hline $\begin{array}{l}\text { \#Employers * Ind. } \\
\text { Homogeneity }\end{array}$ & & & $\begin{array}{c}0.225 \\
(0.167)\end{array}$ & & & & & \\
\hline \multicolumn{9}{|l|}{ Firm Characteristics } \\
\hline Pre-turnover Policy & $\begin{array}{c}0.302 * * * \\
(0.000)\end{array}$ & $\begin{array}{c}0.301 * * * \\
(0.000)\end{array}$ & $\begin{array}{c}0.543 * * * \\
(0.000)\end{array}$ & $\begin{array}{c}0.545^{* * *} \\
(0.000)\end{array}$ & $\begin{array}{c}0.190^{* * *} \\
(0.000)\end{array}$ & $\begin{array}{l}0.189 * * * \\
(0.000)\end{array}$ & $\begin{array}{c}0.194 * * * \\
(0.000)\end{array}$ & $\begin{array}{l}0.190^{* * * *} \\
(0.000)\end{array}$ \\
\hline $\ln$ (Total Sales) & $\begin{array}{c}0.022 * * * \\
(0.000)\end{array}$ & $\begin{array}{c}-0.002 * * \\
(0.024)\end{array}$ & $\begin{array}{c}-0.002 * * * \\
(0.006)\end{array}$ & $\begin{array}{l}0.001^{*} \\
(0.075)\end{array}$ & $\begin{array}{c}-0.019 * * * \\
(0.000)\end{array}$ & $\begin{array}{c}-0.031 * * * \\
(0.000)\end{array}$ & $\begin{array}{c}-0.019 * * * \\
(0.000)\end{array}$ & $\begin{array}{c}-0.019 * * * \\
(0.000)\end{array}$ \\
\hline Firm Age & $\begin{array}{l}-0.004 \\
(0.589)\end{array}$ & $\begin{array}{c}0.000 \\
(0.848)\end{array}$ & $\begin{array}{c}-0.003 * * * \\
(0.003)\end{array}$ & $\begin{array}{c}0.001 \\
(0.323)\end{array}$ & $\begin{array}{c}-0.020^{* * *} \\
(0.000)\end{array}$ & $\begin{array}{c}-0.063 * * * \\
(0.000)\end{array}$ & $\begin{array}{c}-0.016^{* * *} \\
(0.000)\end{array}$ & $\begin{array}{c}-0.015^{* * *} \\
(0.000)\end{array}$ \\
\hline $\begin{array}{l}\text { Operating Return on } \\
\text { Assets }\end{array}$ & $\begin{array}{c}-0.571 * * * \\
(0.000)\end{array}$ & & & & $\begin{array}{l}-0.281 * * * \\
(0.000)\end{array}$ & $\begin{array}{l}-0.609^{* * *} \\
(0.000)\end{array}$ & $\begin{array}{c}-0.228^{* * * *} \\
(0.000)\end{array}$ & $\begin{array}{c}-0.210^{* * *} \\
(0.000)\end{array}$ \\
\hline Surplus Cash & & $\begin{array}{c}0.018^{* *} \\
(0.038)\end{array}$ & $\begin{array}{c}0.126^{* * *} \\
(0.000)\end{array}$ & $\begin{array}{l}-0.010 \\
(0.279)\end{array}$ & & & & \\
\hline Tobin's Q & $\begin{array}{c}-0.022 * * * \\
(0.000)\end{array}$ & $\begin{array}{c}0.003 * * * \\
(0.002)\end{array}$ & $\begin{array}{l}-0.001 \\
(0.543)\end{array}$ & $\begin{array}{c}0.001 * * * \\
(0.008)\end{array}$ & $\begin{array}{c}0.007^{* *} \\
(0.012)\end{array}$ & $\begin{array}{c}0.055^{* * *} \\
(0.000)\end{array}$ & $\begin{array}{l}0.005^{*} \\
(0.084)\end{array}$ & $\begin{array}{c}0.004 \\
(0.133)\end{array}$ \\
\hline R\&D/Total Assets & $\begin{array}{c}-0.383^{* * *} \\
(0.000)\end{array}$ & $\begin{array}{l}-0.033 \\
(0.147)\end{array}$ & & $\begin{array}{c}0.004 \\
(0.791)\end{array}$ & $\begin{array}{c}0.467 * * * \\
(0.000)\end{array}$ & $\begin{array}{c}1.023 * * * \\
(0.000)\end{array}$ & $\begin{array}{c}0.410 * * * \\
(0.000)\end{array}$ & $\begin{array}{c}0.386^{* * *} \\
(0.000)\end{array}$ \\
\hline Adv./Total Assets & & $\begin{array}{c}0.013 \\
(0.719)\end{array}$ & $\begin{array}{l}-0.018 \\
(0.611)\end{array}$ & & $\begin{array}{l}0.168 \\
(0.135)\end{array}$ & $\begin{array}{l}-0.127 \\
(0.729)\end{array}$ & $\begin{array}{l}0.189^{*} \\
(0.080)\end{array}$ & $\begin{array}{l}0.195^{*} \\
(0.066)\end{array}$ \\
\hline CAPEXP & & & $\begin{array}{l}-0.007 \\
(0.659)\end{array}$ & $\begin{array}{l}0.016^{*} \\
(0.085)\end{array}$ & $\begin{array}{c}0.284 * * * \\
(0.000)\end{array}$ & $\begin{array}{c}0.564 * * * \\
(0.008)\end{array}$ & $\begin{array}{c}0.240 * * * \\
(0.000)\end{array}$ & $\begin{array}{c}0.221 * * * \\
(0.000)\end{array}$ \\
\hline Leverage & & $\begin{array}{l}-0.012 \\
(0.113)\end{array}$ & $\begin{array}{l}0.010 * * \\
(0.022)\end{array}$ & $\begin{array}{l}-0.006^{*} \\
(0.066)\end{array}$ & $\begin{array}{c}0.070 * * * \\
(0.001)\end{array}$ & $\begin{array}{c}0.049 \\
(0.514)\end{array}$ & $\begin{array}{c}0.075^{* * *} \\
(0.000)\end{array}$ & $\begin{array}{c}0.075 * * * \\
(0.000)\end{array}$ \\
\hline Industry Homog & & & $\begin{array}{l}-0.023 \\
(0.492)\end{array}$ & & & & & \\
\hline Capital Intensity & $\begin{array}{c}0.120^{* * *} \\
(0.000)\end{array}$ & & & & & & & \\
\hline Depr./Total Assets & $\begin{array}{l}-0.074 \\
(0.695)\end{array}$ & & & & & & & \\
\hline $\begin{array}{l}\text { Pay Directors Equity } \\
\text { Based Compensation }\end{array}$ & $\begin{array}{l}0.013^{*} \\
(0.063)\end{array}$ & $\begin{array}{l}-0.001 \\
(0.553)\end{array}$ & $\begin{array}{c}0.002 \\
(0.228)\end{array}$ & $\begin{array}{l}0.002^{*} \\
(0.077)\end{array}$ & $\begin{array}{c}0.009 \\
(0.180)\end{array}$ & $\begin{array}{c}0.004 \\
(0.880)\end{array}$ & $\begin{array}{c}0.008 \\
(0.207)\end{array}$ & $\begin{array}{c}0.008 \\
(0.184)\end{array}$ \\
\hline
\end{tabular}


Table B.1.6 Continued

\begin{tabular}{|c|c|c|c|c|c|c|c|c|}
\hline \multicolumn{9}{|c|}{ Firm Characteristics (Continued) } \\
\hline $\begin{array}{l}\text { Activist Institutional } \\
\text { Holding (\%) }\end{array}$ & $\begin{array}{l}-0.215 \\
(0.407)\end{array}$ & $\begin{array}{l}-0.068 \\
(0.292)\end{array}$ & $\begin{array}{c}0.053 \\
(0.223)\end{array}$ & $\begin{array}{l}-0.011 \\
(0.785)\end{array}$ & $\begin{array}{l}-0.115 \\
(0.578)\end{array}$ & $\begin{array}{l}1.574^{* *} \\
(0.024)\end{array}$ & $\begin{array}{l}-0.280 \\
(0.161)\end{array}$ & $\begin{array}{l}-0.294 \\
(0.133)\end{array}$ \\
\hline $\begin{array}{l}\text { CEO Cash } \\
\text { Compensation }\end{array}$ & $\begin{array}{c}0.017^{* *} \\
(0.022)\end{array}$ & $\begin{array}{l}-0.003 \\
(0.104)\end{array}$ & $\begin{array}{c}0.006^{* * *} \\
(0.003)\end{array}$ & $\begin{array}{c}0.002^{* *} \\
(0.031)\end{array}$ & $\begin{array}{l}-0.013^{*} \\
(0.059)\end{array}$ & $\begin{array}{c}-0.097 * * * \\
(0.000)\end{array}$ & $\begin{array}{l}-0.007 \\
(0.206)\end{array}$ & $\begin{array}{l}-0.006 \\
(0.277)\end{array}$ \\
\hline $\begin{array}{l}\text { CEO Compensation } \\
\text { Delta }\end{array}$ & $\begin{array}{l}-0.006 \\
(0.137)\end{array}$ & $\begin{array}{l}-0.001 \\
(0.319)\end{array}$ & $\begin{array}{l}-0.001 \\
(0.164)\end{array}$ & $\begin{array}{c}0.001 \\
(0.211)\end{array}$ & $\begin{array}{c}0.002 \\
(0.523)\end{array}$ & $\begin{array}{c}0.022 \\
(0.192)\end{array}$ & $\begin{array}{c}0.000 \\
(0.948)\end{array}$ & $\begin{array}{l}-0.000 \\
(0.958)\end{array}$ \\
\hline $\begin{array}{l}\text { CEO Compensation } \\
\text { Vega }\end{array}$ & $\begin{array}{c}-0.020^{* *} \\
(0.049)\end{array}$ & $\begin{array}{l}-0.000 \\
(0.852)\end{array}$ & $\begin{array}{c}0.005^{* *} \\
(0.011)\end{array}$ & $\begin{array}{l}-0.002 \\
(0.241)\end{array}$ & $\begin{array}{l}-0.011 \\
(0.151)\end{array}$ & $\begin{array}{c}-0.071^{* *} \\
(0.027)\end{array}$ & $\begin{array}{l}-0.011 \\
(0.123)\end{array}$ & $\begin{array}{l}-0.010 \\
(0.145)\end{array}$ \\
\hline Herfindhal Index & $\begin{array}{c}0.358 * * * \\
(0.003)\end{array}$ & $\begin{array}{l}-0.039 \\
(0.299)\end{array}$ & $\begin{array}{l}-0.013 \\
(0.554)\end{array}$ & $\begin{array}{c}0.028 \\
(0.194)\end{array}$ & $\begin{array}{c}0.357 * * * \\
(0.001)\end{array}$ & $\begin{array}{c}0.398 \\
(0.360)\end{array}$ & $\begin{array}{c}0.309^{* * *} \\
(0.002)\end{array}$ & $\begin{array}{c}0.292 * * * \\
(0.003)\end{array}$ \\
\hline \multicolumn{9}{|l|}{ CEO Characteristics } \\
\hline $\mathrm{Ln}(\mathrm{CEO}$ Tenure+1) & $\begin{array}{l}-0.007 \\
(0.294)\end{array}$ & $\begin{array}{l}-0.001 \\
(0.686)\end{array}$ & $\begin{array}{c}0.002 \\
(0.121)\end{array}$ & $\begin{array}{c}-0.002 * * * \\
(0.008)\end{array}$ & $\begin{array}{l}-0.004 \\
(0.433)\end{array}$ & $\begin{array}{c}0.002 \\
(0.922)\end{array}$ & $\begin{array}{l}-0.007 \\
(0.144)\end{array}$ & $\begin{array}{l}-0.007^{*} \\
(0.092)\end{array}$ \\
\hline CEO Age & $\begin{array}{l}-0.017 \\
(0.637)\end{array}$ & $\begin{array}{c}-0.030 * * * \\
(0.001)\end{array}$ & $\begin{array}{c}-0.023 * * * \\
(0.002)\end{array}$ & $\begin{array}{c}0.003 \\
(0.525)\end{array}$ & $\begin{array}{l}-0.027 \\
(0.329)\end{array}$ & $\begin{array}{c}0.034 \\
(0.709)\end{array}$ & $\begin{array}{l}-0.021 \\
(0.419)\end{array}$ & $\begin{array}{l}-0.019 \\
(0.440)\end{array}$ \\
\hline $\operatorname{MBA}(0 / 1)$ & $\begin{array}{c}0.013 \\
(0.103)\end{array}$ & $\begin{array}{l}-0.002 \\
(0.357)\end{array}$ & $\begin{array}{c}0.002 \\
(0.303)\end{array}$ & $\begin{array}{l}-0.001 \\
(0.384)\end{array}$ & $\begin{array}{l}-0.010^{*} \\
(0.065)\end{array}$ & $\begin{array}{c}0.003 \\
(0.886)\end{array}$ & $\begin{array}{c}-0.010 * * \\
(0.050)\end{array}$ & $\begin{array}{c}-0.010 * * \\
(0.041)\end{array}$ \\
\hline Founder $(0 / 1)$ & $\begin{array}{c}0.016 \\
(0.266)\end{array}$ & $\begin{array}{l}-0.005 \\
(0.195)\end{array}$ & $\begin{array}{c}-0.006^{* *} \\
(0.047)\end{array}$ & $\begin{array}{l}-0.002 \\
(0.354)\end{array}$ & $\begin{array}{c}0.023 * * \\
(0.038)\end{array}$ & $\begin{array}{c}0.056 \\
(0.108)\end{array}$ & $\begin{array}{c}0.021 * * \\
(0.038)\end{array}$ & $\begin{array}{l}0.020 * * \\
(0.037)\end{array}$ \\
\hline \# Functional Areas & $\begin{array}{l}-0.002 \\
(0.680)\end{array}$ & $\begin{array}{l}-0.001 \\
(0.394)\end{array}$ & $\begin{array}{c}0.001 \\
(0.495)\end{array}$ & $\begin{array}{l}-0.001 \\
(0.387)\end{array}$ & $\begin{array}{l}0.003 \\
(0.296)\end{array}$ & $\begin{array}{c}0.007 \\
(0.511)\end{array}$ & $\begin{array}{c}0.002 \\
(0.460)\end{array}$ & $\begin{array}{c}0.001 \\
(0.638)\end{array}$ \\
\hline $\begin{array}{l}\text { Has Finance } \\
\text { Background }(0 / 1)\end{array}$ & $\begin{array}{c}0.010 \\
(0.264)\end{array}$ & $\begin{array}{l}-0.005^{*} \\
(0.087)\end{array}$ & $\begin{array}{c}-0.005 * * * \\
(0.001)\end{array}$ & $\begin{array}{l}-0.001 \\
(0.459)\end{array}$ & $\begin{array}{c}0.001 \\
(0.875)\end{array}$ & $\begin{array}{c}0.000 \\
(0.989)\end{array}$ & $\begin{array}{l}0.001 \\
(0.826)\end{array}$ & $\begin{array}{c}0.001 \\
(0.851)\end{array}$ \\
\hline Constant & $\begin{array}{c}0.005 \\
(0.973)\end{array}$ & $\begin{array}{c}0.205^{* * *} \\
(0.000)\end{array}$ & $\begin{array}{c}0.131^{* * *} \\
(0.000)\end{array}$ & $\begin{array}{l}-0.012 \\
(0.595)\end{array}$ & $\begin{array}{c}0.508 * * * \\
(0.000)\end{array}$ & $\begin{array}{l}1.116^{* *} \\
(0.010)\end{array}$ & $\begin{array}{c}0.467 * * * \\
(0.000)\end{array}$ & $\begin{array}{c}0.461^{* * *} \\
(0.000)\end{array}$ \\
\hline Year Dummies & Yes & Yes & Yes & Yes & Yes & Yes & Yes & Yes \\
\hline Industry Dummies & Yes & Yes & Yes & Yes & Yes & Yes & Yes & Yes \\
\hline Observations & 4826 & 5029 & 4914 & 5074 & 4693 & 4693 & 4693 & 4693 \\
\hline R-squared & 0.565 & 0.513 & 0.764 & 0.634 & 0.631 & 0.447 & 0.650 & 0.648 \\
\hline Hansen's J-test (p-value) & 0.653 & 0.489 & 0.112 & 0.531 & 0.14 & 0.749 & 0.138 & 0.174 \\
\hline $\begin{array}{l}\text { First Stage } F \text {-stat for } \\
\text { \#Employers }\end{array}$ & 57.16 & 55.04 & 53.48 & 50.21 & 62.59 & 79.63 & 55.98 & 59.09 \\
\hline $\begin{array}{l}\text { First Stage F-stat for \#Em } \\
\text { Homogeneity }\end{array}$ & mployers ' & dustry & 47.41 & & & & & \\
\hline
\end{tabular}


Table B.1.6 Continued

Panel B: CEO Employment History Proxy: Employer Change Recency

\begin{tabular}{|c|c|c|c|c|c|c|c|c|}
\hline & Leverage & CAPEXP & R\&D & Adv. & $\begin{array}{c}\text { Total Risk } \\
\text { (Daily } \\
\text { Stock } \\
\text { Return Std.) }\end{array}$ & $\begin{array}{c}\text { Market } \\
\text { Risk } \\
\text { (CAPM) }\end{array}$ & $\begin{array}{c}\text { Firm- } \\
\text { specific } \\
\text { Risk } \\
\text { (CAPM) } \\
\end{array}$ & $\begin{array}{c}\text { Firm- } \\
\text { specific } \\
\text { Risk } \\
\text { (4- Factor) } \\
\end{array}$ \\
\hline & $(+)$ & $(-)$ & $(+)$ & $(+)$ & $(+)$ & $(+)$ & $(+)$ & $(+)$ \\
\hline \#Employers & $\begin{array}{l}0.016 * * \\
(0.042)\end{array}$ & $\begin{array}{c}-0.005 * * * \\
(0.006)\end{array}$ & $\begin{array}{c}-0.022 * * \\
(0.030)\end{array}$ & $\begin{array}{l}0.002 * \\
(0.080)\end{array}$ & $\begin{array}{l}0.008 * \\
(0.067)\end{array}$ & $\begin{array}{l}-0.010 \\
(0.511)\end{array}$ & $\begin{array}{l}0.009 * * \\
(0.018)\end{array}$ & $\begin{array}{c}0.010 * * * \\
(0.008)\end{array}$ \\
\hline $\begin{array}{l}\text { \#Employers * Ind. } \\
\text { Homogeneity }\end{array}$ & & & $\begin{array}{l}0.099 * \\
(0.053)\end{array}$ & & & & & \\
\hline \multicolumn{9}{|l|}{ Firm Characteristics } \\
\hline Pre-turnover Policy & $\begin{array}{c}0.306^{* * *} \\
(0.000)\end{array}$ & $\begin{array}{c}0.301 * * * \\
(0.000)\end{array}$ & $\begin{array}{c}0.560 * * * \\
(0.000)\end{array}$ & $\begin{array}{c}0.544 * * * \\
(0.000)\end{array}$ & $\begin{array}{l}0.190 * * * \\
(0.000)\end{array}$ & $\begin{array}{c}0.189 * * * \\
(0.000)\end{array}$ & $\begin{array}{c}0.197 * * * \\
(0.000)\end{array}$ & $\begin{array}{c}0.193 * * * \\
(0.000)\end{array}$ \\
\hline $\ln$ (Total Sales) & $\begin{array}{c}0.021 * * * \\
(0.000)\end{array}$ & $\begin{array}{c}-0.002 * * \\
(0.027)\end{array}$ & $\begin{array}{l}-0.001 * \\
(0.082)\end{array}$ & $\begin{array}{l}0.001 * \\
(0.075)\end{array}$ & $\begin{array}{c}-0.019 * * * \\
(0.000)\end{array}$ & $\begin{array}{c}-0.030 * * * \\
(0.000)\end{array}$ & $\begin{array}{c}-0.019 * * * \\
(0.000)\end{array}$ & $\begin{array}{c}-0.019 * * * \\
(0.000)\end{array}$ \\
\hline Firm Age & $\begin{array}{l}-0.006 \\
(0.402)\end{array}$ & $\begin{array}{c}0.000 \\
(0.815)\end{array}$ & $\begin{array}{c}-0.003 * * \\
(0.016)\end{array}$ & $\begin{array}{c}0.001 \\
(0.348)\end{array}$ & $\begin{array}{c}-0.020 * * * \\
(0.000)\end{array}$ & $\begin{array}{c}-0.062 * * * \\
(0.000)\end{array}$ & $\begin{array}{c}-0.017 * * * \\
(0.000)\end{array}$ & $\begin{array}{c}-0.016^{* * *} \\
(0.000)\end{array}$ \\
\hline $\begin{array}{l}\text { Operating Return on } \\
\text { Assets }\end{array}$ & $\begin{array}{c}-0.576^{* * *} \\
(0.000)\end{array}$ & & & & $\begin{array}{c}-0.284 * * * \\
(0.000)\end{array}$ & $\begin{array}{c}-0.605 * * * \\
(0.000)\end{array}$ & $\begin{array}{c}-0.231 * * * \\
(0.000)\end{array}$ & $\begin{array}{c}-0.214 * * * \\
(0.000)\end{array}$ \\
\hline Surplus Cash & & $\begin{array}{c}0.020 * * \\
(0.020)\end{array}$ & $\begin{array}{c}0.121 * * * \\
(0.000)\end{array}$ & $\begin{array}{c}-0.011 \\
(0.252)\end{array}$ & & & & \\
\hline Tobin's Q & $\begin{array}{c}-0.022 * * * \\
(0.000)\end{array}$ & $\begin{array}{c}0.003 * * * \\
(0.003)\end{array}$ & $\begin{array}{l}-0.001 \\
(0.662)\end{array}$ & $\begin{array}{c}0.001 * * * \\
(0.009)\end{array}$ & $\begin{array}{c}0.007 * * \\
(0.011)\end{array}$ & $\begin{array}{c}0.055^{* * *} \\
(0.000)\end{array}$ & $\begin{array}{l}0.005 * \\
(0.081)\end{array}$ & $\begin{array}{c}0.004 \\
(0.129)\end{array}$ \\
\hline R\&D/Total Assets & $\begin{array}{c}-0.376^{* * *} \\
(0.000)\end{array}$ & $\begin{array}{l}-0.035 \\
(0.123)\end{array}$ & & $\begin{array}{c}0.004 \\
(0.814)\end{array}$ & $\begin{array}{c}0.468 * * * \\
(0.000)\end{array}$ & $\begin{array}{c}1.019 * * * \\
(0.000)\end{array}$ & $\begin{array}{c}0.411 * * * \\
(0.000)\end{array}$ & $\begin{array}{c}0.387 * * * \\
(0.000)\end{array}$ \\
\hline Adv./Total Assets & & $\begin{array}{c}0.017 \\
(0.641)\end{array}$ & $\begin{array}{l}-0.031 \\
(0.421)\end{array}$ & & $\begin{array}{c}0.156 \\
(0.164)\end{array}$ & $\begin{array}{l}-0.114 \\
(0.756)\end{array}$ & $\begin{array}{l}0.176^{*} \\
(0.099)\end{array}$ & $\begin{array}{l}0.182^{*} \\
(0.083)\end{array}$ \\
\hline CAPEXP & & & $\begin{array}{l}-0.006 \\
(0.731)\end{array}$ & $\begin{array}{l}0.016 * \\
(0.086)\end{array}$ & $\begin{array}{c}0.286 * * * \\
(0.000)\end{array}$ & $\begin{array}{c}0.562 * * * \\
(0.009)\end{array}$ & $\begin{array}{c}0.241 * * * \\
(0.000)\end{array}$ & $\begin{array}{c}0.223 * * * \\
(0.000)\end{array}$ \\
\hline Leverage & & $\begin{array}{l}-0.012 \\
(0.123)\end{array}$ & $\begin{array}{c}0.003 \\
(0.686)\end{array}$ & $\begin{array}{l}-0.007 * \\
(0.055)\end{array}$ & $\begin{array}{c}0.070 * * * \\
(0.001)\end{array}$ & $\begin{array}{c}0.047 \\
(0.529)\end{array}$ & $\begin{array}{c}0.076^{* * * *} \\
(0.000)\end{array}$ & $\begin{array}{c}0.076 * * * \\
(0.000)\end{array}$ \\
\hline Industry Homogeneity & & & $\begin{array}{l}-0.118 * \\
(0.071)\end{array}$ & & & & & \\
\hline Capital Intensity & $\begin{array}{c}0.117 * * * \\
(0.000)\end{array}$ & & & & & & & \\
\hline Depr./Total Assets & $\begin{array}{l}-0.088 \\
(0.638)\end{array}$ & & & & & & & \\
\hline Pay Directors Equity & $0.012 *$ & -0.001 & 0.002 & 0.002 & 0.009 & 0.004 & 0.007 & 0.008 \\
\hline Based Compensation & $(0.080)$ & $(0.770)$ & $(0.202)$ & $(0.102)$ & $(0.202)$ & $(0.863)$ & $(0.228)$ & $(0.205)$ \\
\hline Activist Institutional & $\begin{array}{l}-0.216 \\
(0.403)\end{array}$ & $\begin{array}{l}-0.054 \\
(0.394)\end{array}$ & $\begin{array}{c}0.071 \\
(0.117)\end{array}$ & $\begin{array}{l}-0.013 \\
(0.741)\end{array}$ & $\begin{array}{l}-0.119 \\
(0.562)\end{array}$ & $\begin{array}{l}1.575^{* *} \\
(0.024)\end{array}$ & $\begin{array}{l}-0.281 \\
(0.151)\end{array}$ & $\begin{array}{l}-0.296 \\
(0.123)\end{array}$ \\
\hline CEO Cash & $\begin{array}{c}0.017 * * \\
(0.025)\end{array}$ & $\begin{array}{l}-0.003 \\
(0.122)\end{array}$ & $\begin{array}{c}0.007 * * * \\
(0.001)\end{array}$ & $\begin{array}{c}0.002 * * \\
(0.035)\end{array}$ & $\begin{array}{l}-0.013 * \\
(0.055)\end{array}$ & $\begin{array}{c}-0.096 * * * \\
(0.000)\end{array}$ & $\begin{array}{l}-0.008 \\
(0.189)\end{array}$ & $\begin{array}{l}-0.006 \\
(0.253)\end{array}$ \\
\hline CEO Compensation & $\begin{array}{l}-0.007 * \\
(0.078)\end{array}$ & $\begin{array}{l}-0.001 \\
(0.430)\end{array}$ & $\begin{array}{l}-0.001 \\
(0.679)\end{array}$ & $\begin{array}{c}0.001 \\
(0.238)\end{array}$ & $\begin{array}{c}0.002 \\
(0.598)\end{array}$ & $\begin{array}{c}0.022 \\
(0.177)\end{array}$ & $\begin{array}{l}-0.000 \\
(0.941)\end{array}$ & $\begin{array}{l}-0.001 \\
(0.836)\end{array}$ \\
\hline CEO Compensation & $\begin{array}{c}-0.017^{*} \\
(0.074)\end{array}$ & $\begin{array}{c}-0.001 \\
(0.701)\end{array}$ & $\begin{array}{c}0.003 \\
(0.209)\end{array}$ & $\begin{array}{c}-0.002 \\
(0.271)\end{array}$ & $\begin{array}{l}-0.010 \\
(0.181)\end{array}$ & $\begin{array}{c}-0.073 * * \\
(0.021)\end{array}$ & $\begin{array}{c}-0.009 \\
(0.170)\end{array}$ & $\begin{array}{c}-0.008 \\
(0.207)\end{array}$ \\
\hline Herfindhal Index & $\begin{array}{c}0.341 * * * \\
(0.006)\end{array}$ & $\begin{array}{c}-0.038 \\
(0.330)\end{array}$ & $\begin{array}{c}-0.013 \\
(0.625)\end{array}$ & $\begin{array}{c}0.029 \\
(0.185)\end{array}$ & $\begin{array}{c}0.354 * * * \\
(0.001)\end{array}$ & $\begin{array}{c}0.403 \\
(0.353)\end{array}$ & $\begin{array}{c}0.305 * * * \\
(0.002)\end{array}$ & $\begin{array}{c}0.287 * * * \\
(0.003)\end{array}$ \\
\hline
\end{tabular}


Table B.1.6 Continued

\begin{tabular}{lcccccccc}
\hline CEO Characteristics & & & & & & & & \\
Ln(CEO Tenure+1) & 0.003 & $-0.004^{* *}$ & -0.000 & $-0.001^{*}$ & 0.000 & -0.004 & -0.002 & -0.002 \\
& $(0.608)$ & $(0.024)$ & $(0.849)$ & $(0.100)$ & $(0.968)$ & $(0.789)$ & $(0.673)$ & $(0.592)$ \\
CEO Age & $-0.077^{* *}$ & -0.012 & $-0.013^{*}$ & -0.003 & $-0.053^{* *}$ & 0.073 & $-0.054^{* *}$ & $-0.055^{* *}$ \\
& $(0.019)$ & $(0.181)$ & $(0.080)$ & $(0.451)$ & $(0.037)$ & $(0.406)$ & $(0.021)$ & $(0.015)$ \\
MBA (0/1) & $0.014^{*}$ & -0.002 & 0.002 & -0.001 & $-0.009^{*}$ & 0.001 & $-0.009^{*}$ & $-0.009^{*}$ \\
& $(0.063)$ & $(0.285)$ & $(0.322)$ & $(0.451)$ & $(0.086)$ & $(0.954)$ & $(0.079)$ & $(0.069)$ \\
Founder (0/1) & 0.014 & -0.005 & -0.004 & -0.002 & $0.023^{* *}$ & 0.057 & $0.021^{* *}$ & $0.020^{* *}$ \\
& $(0.321)$ & $(0.174)$ & $(0.318)$ & $(0.352)$ & $(0.033)$ & $(0.107)$ & $(0.036)$ & $(0.035)$ \\
\# Functional Areas & -0.001 & -0.001 & 0.001 & -0.000 & 0.003 & 0.006 & 0.002 & 0.002 \\
& $(0.765)$ & $(0.337)$ & $(0.518)$ & $(0.398)$ & $(0.262)$ & $(0.541)$ & $(0.376)$ & $(0.530)$ \\
Has Finance & 0.012 & $-0.005^{*}$ & $-0.007 * * *$ & -0.001 & 0.001 & -0.000 & 0.002 & 0.002 \\
Background (0/1) & $(0.198)$ & $(0.072)$ & $(0.001)$ & $(0.481)$ & $(0.842)$ & $(0.992)$ & $(0.773)$ & $(0.792)$ \\
Constant & $0.283^{* *}$ & $0.132^{* * *}$ & $0.097 * * *$ & 0.013 & $0.617 * * *$ & $0.949 * *$ & $0.602^{* * *}$ & $0.606^{* * *}$ \\
& $(0.039)$ & $(0.000)$ & $(0.003)$ & $(0.542)$ & $(0.000)$ & $(0.011)$ & $(0.000)$ & $(0.000)$ \\
Year Dummies & Yes & Yes & Yes & Yes & Yes & Yes & Yes & Yes \\
Industry Dummies & Yes & Yes & Yes & Yes & Yes & Yes & Yes & Yes \\
Observations & 4826 & 5029 & 4914 & 5074 & 4693 & 4693 & 4693 & 4693 \\
R-squared & 0.573 & 0.513 & 0.729 & 0.634 & 0.633 & 0.447 & 0.654 & 0.652 \\
& & & & & & & & \\
Hansen's J-test (p-value) & 0.759 & 0.818 & 0.460 & 0.569 & 0.131 & 0.708 & 0.121 & 0.150 \\
First Stage F-stat for & 62.88 & 65.67 & 46.56 & 50.99 & 68.92 & 93.96 & 72.06 & 72.29 \\
\#Employers & & & & & & & & \\
First Stage F-stat for \#Employers * Industry & 34.82 & & & & & \\
Homogeneity & & & & & & & & \\
F & & & & & & &
\end{tabular}


Table B.1.6 Continued

Panel C: CEO Employment History Proxy: Firm Experience Diversification

\begin{tabular}{|c|c|c|c|c|c|c|c|c|}
\hline & Leverage & CAPEXP & $R \& D$ & Adv. & $\begin{array}{c}\text { Total Risk } \\
\text { (Ann. Daily } \\
\text { Stock } \\
\text { Return Std.) }\end{array}$ & $\begin{array}{c}\text { Market } \\
\text { Risk } \\
\text { (CAPM) } \\
\end{array}$ & $\begin{array}{c}\text { Firm- } \\
\text { specific } \\
\text { Risk } \\
\text { (CAPM) }\end{array}$ & $\begin{array}{c}\text { Firm- } \\
\text { specific } \\
\text { Risk } \\
\text { (4- Factor) }\end{array}$ \\
\hline & $(+)$ & $(-)$ & $(+)$ & $(+)$ & $(+)$ & $(+)$ & $(+)$ & $(+)$ \\
\hline \#Employers & $\begin{array}{c}-0.081 * * \\
(0.023)\end{array}$ & $\begin{array}{c}0.023 * * * \\
(0.009)\end{array}$ & $\begin{array}{l}0.133^{*} \\
(0.098)\end{array}$ & $\begin{array}{l}-0.007 \\
(0.117)\end{array}$ & $\begin{array}{l}-0.025 \\
(0.212)\end{array}$ & $\begin{array}{c}0.053 \\
(0.485)\end{array}$ & $\begin{array}{c}-0.037 * * \\
(0.048)\end{array}$ & $\begin{array}{c}-0.041 * * \\
(0.024)\end{array}$ \\
\hline $\begin{array}{l}\text { \#Employers * Ind. } \\
\text { Homogeneity }\end{array}$ & & & $\begin{array}{l}-0.608^{*} \\
(0.098)\end{array}$ & & & & & \\
\hline \multicolumn{9}{|l|}{ Firm Characteristics } \\
\hline Pre-turnover Policy & $\begin{array}{c}0.308^{* * *} \\
(0.000)\end{array}$ & $\begin{array}{c}0.307^{* * *} \\
(0.000)\end{array}$ & $\begin{array}{c}0.554 * * * \\
(0.000)\end{array}$ & $\begin{array}{c}0.543 * * * \\
(0.000)\end{array}$ & $\begin{array}{c}0.196^{* * * *} \\
(0.000)\end{array}$ & $\begin{array}{c}0.188^{* * *} \\
(0.000)\end{array}$ & $\begin{array}{c}0.202 * * * \\
(0.000)\end{array}$ & $\begin{array}{c}0.199 * * * \\
(0.000)\end{array}$ \\
\hline $\ln$ (Total Sales) & $\begin{array}{l}0.022 * * * \\
(0.000)\end{array}$ & $\begin{array}{c}-0.002 * * \\
(0.024)\end{array}$ & $\begin{array}{l}-0.001 \\
(0.355)\end{array}$ & $\begin{array}{l}0.001^{*} \\
(0.090)\end{array}$ & $\begin{array}{c}-0.019 * * * \\
(0.000)\end{array}$ & $\begin{array}{c}-0.031 * * * \\
(0.000)\end{array}$ & $\begin{array}{c}-0.019 * * * \\
(0.000)\end{array}$ & $\begin{array}{c}-0.019 * * * \\
(0.000)\end{array}$ \\
\hline Firm Age & $\begin{array}{l}-0.002 \\
(0.794)\end{array}$ & $\begin{array}{l}-0.000 \\
(0.988)\end{array}$ & $\begin{array}{l}-0.002 \\
(0.138)\end{array}$ & $\begin{array}{c}0.001 \\
(0.257)\end{array}$ & $\begin{array}{c}-0.019^{* * *} \\
(0.000)\end{array}$ & $\begin{array}{c}-0.064 * * * \\
(0.000)\end{array}$ & $\begin{array}{c}-0.015^{* * *} \\
(0.001)\end{array}$ & $\begin{array}{c}-0.015^{* * *} \\
(0.001)\end{array}$ \\
\hline $\begin{array}{l}\text { Operating Return on } \\
\text { Assets }\end{array}$ & $\begin{array}{c}-0.575^{* * *} \\
(0.000)\end{array}$ & & & & $\begin{array}{c}-0.283 * * * \\
(0.000)\end{array}$ & $\begin{array}{c}-0.606^{* * *} \\
(0.000)\end{array}$ & $\begin{array}{c}-0.229 * * * \\
(0.000)\end{array}$ & $\begin{array}{c}-0.212 * * * \\
(0.000)\end{array}$ \\
\hline Surplus Cash & & $\begin{array}{c}0.021 * * \\
(0.013)\end{array}$ & $\begin{array}{c}0.118^{* * *} \\
(0.000)\end{array}$ & $\begin{array}{l}-0.011 \\
(0.242)\end{array}$ & & & & \\
\hline Tobin's Q & $\begin{array}{c}-0.023^{* * *} \\
(0.000)\end{array}$ & $\begin{array}{c}0.003 * * * \\
(0.002)\end{array}$ & $\begin{array}{l}-0.000 \\
(0.752)\end{array}$ & $\begin{array}{c}0.001 * * * \\
(0.010)\end{array}$ & $\begin{array}{l}0.007 * * \\
(0.014)\end{array}$ & $\begin{array}{c}0.055^{* * *} \\
(0.000)\end{array}$ & $\begin{array}{c}0.004 \\
(0.102)\end{array}$ & $\begin{array}{c}0.004 \\
(0.162)\end{array}$ \\
\hline R\&D/Total Assets & $\begin{array}{c}-0.346^{* * *} \\
(0.000)\end{array}$ & $\begin{array}{l}-0.043^{*} \\
(0.063)\end{array}$ & & $\begin{array}{c}0.006 \\
(0.687)\end{array}$ & $\begin{array}{c}0.477^{* * * *} \\
(0.000)\end{array}$ & $\begin{array}{c}1.002 * * * \\
(0.000)\end{array}$ & $\begin{array}{c}0.425^{* * *} \\
(0.000)\end{array}$ & $\begin{array}{c}0.402^{* * *} \\
(0.000)\end{array}$ \\
\hline Adv./Total Assets & & $\begin{array}{c}0.017 \\
(0.629)\end{array}$ & $\begin{array}{l}-0.020 \\
(0.646)\end{array}$ & & $\begin{array}{c}0.155 \\
(0.172)\end{array}$ & $\begin{array}{l}-0.110 \\
(0.765)\end{array}$ & $\begin{array}{c}0.174 \\
(0.109)\end{array}$ & $\begin{array}{l}0.179^{*} \\
(0.094)\end{array}$ \\
\hline CAPEXP & & & $\begin{array}{l}-0.018 \\
(0.494)\end{array}$ & $\begin{array}{l}0.016^{*} \\
(0.099)\end{array}$ & $\begin{array}{l}0.282 * * * \\
(0.000)\end{array}$ & $\begin{array}{l}0.562 * * * \\
(0.008)\end{array}$ & $\begin{array}{c}0.239^{* * *} \\
(0.000)\end{array}$ & $\begin{array}{c}0.221^{* * *} \\
(0.000)\end{array}$ \\
\hline Leverage & & $\begin{array}{l}-0.012 \\
(0.113)\end{array}$ & $\begin{array}{c}0.002 \\
(0.753)\end{array}$ & $\begin{array}{l}-0.006^{*} \\
(0.062)\end{array}$ & $\begin{array}{c}0.072^{* * *} \\
(0.001)\end{array}$ & $\begin{array}{c}0.048 \\
(0.523)\end{array}$ & $\begin{array}{c}0.077 * * * \\
(0.000)\end{array}$ & $\begin{array}{c}0.077 * * * \\
(0.000)\end{array}$ \\
\hline Industry Homogeneity & & & $\begin{array}{c}0.350 \\
(0.121)\end{array}$ & & & & & \\
\hline Capital Intensity & $\begin{array}{c}0.114^{* * *} \\
(0.000)\end{array}$ & & & & & & & \\
\hline Depr./Total Assets & $\begin{array}{l}-0.053 \\
(0.774)\end{array}$ & & & & & & & \\
\hline $\begin{array}{l}\text { Pay Directors Equity } \\
\text { Based Compensation }\end{array}$ & $\begin{array}{l}0.012^{*} \\
(0.091)\end{array}$ & $\begin{array}{l}-0.001 \\
(0.711)\end{array}$ & $\begin{array}{c}0.002 \\
(0.262)\end{array}$ & $\begin{array}{l}0.002 * \\
(0.093)\end{array}$ & $\begin{array}{c}0.009 \\
(0.184)\end{array}$ & $\begin{array}{c}0.004 \\
(0.877)\end{array}$ & $\begin{array}{c}0.008 \\
(0.201)\end{array}$ & $\begin{array}{c}0.008 \\
(0.179)\end{array}$ \\
\hline Activist Institutional & $\begin{array}{l}-0.227 \\
(0.381)\end{array}$ & $\begin{array}{l}-0.062 \\
(0.331)\end{array}$ & $\begin{array}{l}0.094 * \\
(0.079)\end{array}$ & $\begin{array}{l}-0.012 \\
(0.750)\end{array}$ & $\begin{array}{l}-0.111 \\
(0.590)\end{array}$ & $\begin{array}{l}1.568 * * \\
(0.024)\end{array}$ & $\begin{array}{l}-0.272 \\
(0.170)\end{array}$ & $\begin{array}{l}-0.286 \\
(0.140)\end{array}$ \\
\hline CEO Cash & $\begin{array}{l}0.018^{* *} \\
(0.018)\end{array}$ & $\begin{array}{l}-0.003 \\
(0.103)\end{array}$ & $\begin{array}{c}0.007^{* * *} \\
(0.004)\end{array}$ & $\begin{array}{l}0.002 * * \\
(0.031)\end{array}$ & $\begin{array}{l}-0.012^{*} \\
(0.069)\end{array}$ & $\begin{array}{c}-0.097 * * * \\
(0.000)\end{array}$ & $\begin{array}{l}-0.007 \\
(0.243)\end{array}$ & $\begin{array}{l}-0.005 \\
(0.329)\end{array}$ \\
\hline CEO Compensation & $\begin{array}{l}-0.006 \\
(0.149)\end{array}$ & $\begin{array}{l}-0.001 \\
(0.220)\end{array}$ & $\begin{array}{c}0.000 \\
(0.849)\end{array}$ & $\begin{array}{c}0.001 \\
(0.186)\end{array}$ & $\begin{array}{c}0.002 \\
(0.530)\end{array}$ & $\begin{array}{c}0.022 \\
(0.196)\end{array}$ & $\begin{array}{c}0.000 \\
(0.922)\end{array}$ & $\begin{array}{l}-0.000 \\
(0.987)\end{array}$ \\
\hline CEO Compensation & $\begin{array}{c}-0.020^{* *} \\
(0.046)\end{array}$ & $\begin{array}{c}0.000 \\
(0.985)\end{array}$ & $\begin{array}{c}0.002 \\
(0.571)\end{array}$ & $\begin{array}{l}-0.002 \\
(0.229)\end{array}$ & $\begin{array}{l}-0.011 \\
(0.173)\end{array}$ & $\begin{array}{c}-0.071^{* *} \\
(0.027)\end{array}$ & $\begin{array}{l}-0.010 \\
(0.139)\end{array}$ & $\begin{array}{l}-0.009 \\
(0.164)\end{array}$ \\
\hline Herfindhal Index & $\begin{array}{c}0.369 * * * \\
(0.003)\end{array}$ & $\begin{array}{l}-0.043 \\
(0.252)\end{array}$ & $\begin{array}{l}-0.006 \\
(0.857)\end{array}$ & $\begin{array}{c}0.029 \\
(0.178)\end{array}$ & $\begin{array}{c}0.357^{* * * *} \\
(0.001)\end{array}$ & $\begin{array}{c}0.395 \\
(0.364)\end{array}$ & $\begin{array}{c}0.311^{* * * *} \\
(0.002)\end{array}$ & $\begin{array}{c}0.294 * * * \\
(0.003)\end{array}$ \\
\hline
\end{tabular}


Table B.1.6 Continued

\begin{tabular}{|c|c|c|c|c|c|c|c|c|}
\hline \multicolumn{9}{|l|}{ CEO Characteristics } \\
\hline \multirow[t]{2}{*}{$\overline{\operatorname{Ln}(\mathrm{CEO} \text { Tenure+1)}}$} & 0.002 & $-0.004 * *$ & -0.000 & -0.001 & -0.001 & -0.004 & -0.003 & -0.003 \\
\hline & $(0.688)$ & $(0.022)$ & $(0.862)$ & $(0.101)$ & $(0.910)$ & $(0.801)$ & $(0.551)$ & $(0.468)$ \\
\hline \multirow[t]{2}{*}{ CEO Age } & $-0.076^{* *}$ & -0.014 & $-0.022 * *$ & -0.003 & $-0.047 *$ & 0.072 & $-0.050 * *$ & $-0.051 * *$ \\
\hline & $(0.018)$ & $(0.124)$ & $(0.027)$ & $(0.555)$ & $(0.065)$ & $(0.408)$ & $(0.033)$ & $(0.025)$ \\
\hline \multirow[t]{2}{*}{$\operatorname{MBA}(0 / 1)$} & 0.013 & -0.002 & 0.002 & -0.001 & $-0.010 *$ & 0.002 & $-0.009 *$ & $-0.009 *$ \\
\hline & $(0.114)$ & $(0.313)$ & $(0.295)$ & $(0.410)$ & $(0.092)$ & $(0.898)$ & $(0.069)$ & $(0.058)$ \\
\hline \multirow[t]{2}{*}{ Founder $(0 / 1)$} & 0.018 & -0.005 & -0.002 & -0.002 & $0.022 * *$ & 0.055 & $0.021 * *$ & $0.020 * *$ \\
\hline & $(0.220)$ & $(0.186)$ & $(0.647)$ & $(0.337)$ & $(0.048)$ & $(0.124)$ & $(0.042)$ & $(0.039)$ \\
\hline \multirow[t]{2}{*}{ \# Functional Areas } & -0.002 & -0.001 & 0.001 & -0.000 & 0.003 & 0.006 & 0.002 & 0.002 \\
\hline & $(0.709)$ & $(0.353)$ & $(0.315)$ & $(0.402)$ & $(0.257)$ & $(0.528)$ & $(0.390)$ & $(0.552)$ \\
\hline Has Finance & 0.009 & -0.004 & $-0.008 * * *$ & -0.001 & 0.001 & 0.001 & 0.001 & 0.001 \\
\hline Background (0/1) & $(0.310)$ & $(0.105)$ & $(0.007)$ & $(0.424)$ & $(0.898)$ & $(0.970)$ & $(0.870)$ & $(0.904)$ \\
\hline \multirow[t]{2}{*}{ Constant } & $0.304 * *$ & $0.123 * * *$ & 0.001 & 0.015 & $0.610 * * *$ & $0.929 * *$ & $0.608 * * *$ & $0.613 * * *$ \\
\hline & $(0.042)$ & $(0.001)$ & $(0.991)$ & $(0.488)$ & $(0.000)$ & $(0.014)$ & $(0.000)$ & $(0.000)$ \\
\hline Year Dummies & Yes & Yes & Yes & Yes & Yes & Yes & Yes & Yes \\
\hline Industry Dummies & Yes & Yes & Yes & Yes & Yes & Yes & Yes & Yes \\
\hline Observations & 4826 & 5029 & 4914 & 5074 & 4693 & 4693 & 4693 & 4693 \\
\hline R-squared & 0.568 & 0.515 & 0.673 & 0.633 & 0.632 & 0.447 & 0.652 & 0.650 \\
\hline Hansen's J-test (p-value) & 0.684 & 0.549 & 0.750 & 0.461 & 0.194 & 0.754 & 0.165 & 0.112 \\
\hline First Stage $F$-stat for & 55.39 & 60.81 & 42.68 & 47.32 & 58.5 & 76.71 & 56.18 & 56.19 \\
\hline
\end{tabular}

\#Employers

32.99

Homogeneity

Panel D: CEO Employment History Proxy: Industry Experience Diversification

\begin{tabular}{|c|c|c|c|c|c|c|c|c|}
\hline & Leverage & CAPEXP & $\mathrm{R} \& \mathrm{D}$ & Adv. & $\begin{array}{l}\text { Total Risk } \\
\text { (Ann. Daily } \\
\text { Stock } \\
\text { Return Std.) }\end{array}$ & $\begin{array}{c}\text { Market } \\
\text { Risk } \\
\text { (CAPM) }\end{array}$ & $\begin{array}{c}\text { Firm- } \\
\text { specific } \\
\text { Risk } \\
\text { (CAPM) } \\
\end{array}$ & $\begin{array}{c}\text { Firm- } \\
\text { specific } \\
\text { Risk } \\
\text { (4- Factor) } \\
\end{array}$ \\
\hline & $(+)$ & $(-)$ & $(+)$ & $(+)$ & $(+)$ & $(+)$ & $(+)$ & $(+)$ \\
\hline \#Employers & $\begin{array}{l}-0.061 * * \\
(0.020)\end{array}$ & $\begin{array}{c}0.017 * * * \\
(0.006)\end{array}$ & $\begin{array}{l}0.027 * \\
(0.050)\end{array}$ & $\begin{array}{l}-0.004 \\
(0.172)\end{array}$ & $\begin{array}{l}-0.014 \\
(0.475)\end{array}$ & $\begin{array}{c}0.054 \\
(0.463)\end{array}$ & $\begin{array}{l}-0.027 \\
(0.136)\end{array}$ & $\begin{array}{l}-0.031 * \\
(0.080)\end{array}$ \\
\hline $\begin{array}{l}\text { \#Employers * Ind. } \\
\text { Homogeneity }\end{array}$ & & & $\begin{array}{l}-0.084 \\
(0.184)\end{array}$ & & & & & \\
\hline \multicolumn{9}{|l|}{ Firm Characteristics } \\
\hline Pre-turnover Policy & $\begin{array}{c}0.314 * * * \\
(0.000)\end{array}$ & $\begin{array}{c}0.309 * * * \\
(0.000)\end{array}$ & $\begin{array}{c}0.536^{* * *} \\
(0.000)\end{array}$ & $\begin{array}{c}0.543^{* * *} \\
(0.000)\end{array}$ & $\begin{array}{c}0.197 * * * \\
(0.000)\end{array}$ & $\begin{array}{c}0.189 * * * \\
(0.000)\end{array}$ & $\begin{array}{c}0.205^{* * *} \\
(0.000)\end{array}$ & $\begin{array}{c}0.202 * * * \\
(0.000)\end{array}$ \\
\hline $\ln$ (Total Sales) & $\begin{array}{c}0.019 * * * \\
(0.000)\end{array}$ & $\begin{array}{l}-0.002 * \\
(0.083)\end{array}$ & $\begin{array}{c}-0.002 * * \\
(0.012)\end{array}$ & $\begin{array}{c}0.000 \\
(0.188)\end{array}$ & $\begin{array}{c}-0.020 * * * \\
(0.000)\end{array}$ & $\begin{array}{c}-0.030 * * * \\
(0.000)\end{array}$ & $\begin{array}{c}-0.020 * * * \\
(0.000)\end{array}$ & $\begin{array}{c}-0.020 * * * \\
(0.000)\end{array}$ \\
\hline Firm Age & $\begin{array}{l}-0.005 \\
(0.418)\end{array}$ & $\begin{array}{c}0.001 \\
(0.577)\end{array}$ & $\begin{array}{c}-0.003 * * * \\
(0.007)\end{array}$ & $\begin{array}{c}0.001 \\
(0.490)\end{array}$ & $\begin{array}{c}-0.021 * * * \\
(0.000)\end{array}$ & $\begin{array}{c}-0.063 * * * \\
(0.000)\end{array}$ & $\begin{array}{c}-0.017 * * * \\
(0.000)\end{array}$ & $\begin{array}{c}-0.016 * * * \\
(0.000)\end{array}$ \\
\hline $\begin{array}{l}\text { Operating Return on } \\
\text { Assets }\end{array}$ & $\begin{array}{c}-0.583 * * * \\
(0.000)\end{array}$ & & & & $\begin{array}{c}-0.284 * * * \\
(0.000)\end{array}$ & $\begin{array}{c}-0.600 * * * \\
(0.000)\end{array}$ & $\begin{array}{c}-0.232 * * * \\
(0.000)\end{array}$ & $\begin{array}{c}-0.214 * * * \\
(0.000)\end{array}$ \\
\hline Surplus Cash & & $\begin{array}{c}0.022 * * * \\
(0.009)\end{array}$ & $\begin{array}{c}0.128 * * * \\
(0.000)\end{array}$ & $\begin{array}{c}-0.012 \\
(0.230)\end{array}$ & & & & \\
\hline
\end{tabular}


Table B.1.6 Continued

\begin{tabular}{|c|c|c|c|c|c|c|c|c|}
\hline \multicolumn{9}{|c|}{ Firm Characteristics (Continued) } \\
\hline Tobin's Q & $\begin{array}{c}-0.022 * * * \\
(0.000)\end{array}$ & $\begin{array}{c}0.003 * * * \\
(0.002)\end{array}$ & $\begin{array}{l}-0.001 \\
(0.527)\end{array}$ & $\begin{array}{c}0.001 * * * \\
(0.009)\end{array}$ & $\begin{array}{l}0.007^{* *} \\
(0.012)\end{array}$ & $\begin{array}{c}0.055 * * * \\
(0.000)\end{array}$ & $\begin{array}{l}0.005^{*} \\
(0.084)\end{array}$ & $\begin{array}{c}0.004 \\
(0.133)\end{array}$ \\
\hline $\mathrm{R} \& \mathrm{D} /$ Total Assets & $\begin{array}{c}-0.354^{* * * *} \\
(0.000)\end{array}$ & $\begin{array}{r}-0.041^{*} \\
(0.067)\end{array}$ & & $\begin{array}{c}0.005 \\
(0.735)\end{array}$ & $\begin{array}{c}0.474 * * * \\
(0.000)\end{array}$ & $\begin{array}{c}1.002 * * * \\
(0.000)\end{array}$ & $\begin{array}{c}0.421^{* * *} \\
(0.000)\end{array}$ & $\begin{array}{c}0.397 * * * \\
(0.000)\end{array}$ \\
\hline Adv./Total Assets & & $\begin{array}{c}0.015 \\
(0.664)\end{array}$ & $\begin{array}{l}-0.014 \\
(0.688)\end{array}$ & & $\begin{array}{c}0.158 \\
(0.159)\end{array}$ & $\begin{array}{l}-0.108 \\
(0.769)\end{array}$ & $\begin{array}{c}0.176 \\
(0.100)\end{array}$ & $\begin{array}{l}0.180^{*} \\
(0.086)\end{array}$ \\
\hline CAPEXP & & & $\begin{array}{l}-0.003 \\
(0.845)\end{array}$ & $\begin{array}{l}0.017 * \\
(0.089)\end{array}$ & $\begin{array}{c}0.283 * * * \\
(0.000)\end{array}$ & $\begin{array}{l}0.547 * * \\
(0.011)\end{array}$ & $\begin{array}{c}0.244 * * * \\
(0.000)\end{array}$ & $\begin{array}{c}0.227^{* * *} \\
(0.000)\end{array}$ \\
\hline Leverage & & $\begin{array}{l}-0.013 * \\
(0.085)\end{array}$ & $\begin{array}{l}0.009 * * \\
(0.030)\end{array}$ & $\begin{array}{l}-0.006^{*} \\
(0.070)\end{array}$ & $\begin{array}{c}0.074 * * * \\
(0.001)\end{array}$ & $\begin{array}{c}0.046 \\
(0.541)\end{array}$ & $\begin{array}{c}0.080^{* * *} \\
(0.000)\end{array}$ & $\begin{array}{c}0.080^{* * *} \\
(0.000)\end{array}$ \\
\hline Industry Homogeneity & & & $\begin{array}{c}0.068 \\
(0.140)\end{array}$ & & & & & \\
\hline Capital Intensity & $\begin{array}{c}0.112^{* * *} \\
(0.000)\end{array}$ & & & & & & & \\
\hline Depr./Total Assets & $\begin{array}{l}-0.031 \\
(0.865)\end{array}$ & & & & & & & \\
\hline $\begin{array}{l}\text { Pay Directors Equity } \\
\text { Based Compensation }\end{array}$ & $\begin{array}{l}0.012^{*} \\
(0.083)\end{array}$ & $\begin{array}{l}-0.001 \\
(0.673)\end{array}$ & $\begin{array}{c}0.002 \\
(0.141)\end{array}$ & $\begin{array}{l}0.002^{*} \\
(0.087)\end{array}$ & $\begin{array}{c}0.009 \\
(0.181)\end{array}$ & $\begin{array}{c}0.004 \\
(0.865)\end{array}$ & $\begin{array}{c}0.008 \\
(0.203)\end{array}$ & $\begin{array}{c}0.008 \\
(0.182)\end{array}$ \\
\hline Activist Institutional & $\begin{array}{l}-0.225 \\
(0.378)\end{array}$ & $\begin{array}{l}-0.064 \\
(0.307)\end{array}$ & $\begin{array}{c}0.063 \\
(0.133)\end{array}$ & $\begin{array}{l}-0.013 \\
(0.741)\end{array}$ & $\begin{array}{l}-0.109 \\
(0.595)\end{array}$ & $\begin{array}{l}1.563 * * \\
(0.025)\end{array}$ & $\begin{array}{l}-0.269 \\
(0.172)\end{array}$ & $\begin{array}{l}-0.283 \\
(0.142)\end{array}$ \\
\hline CEO Cash & $\begin{array}{l}0.016^{* *} \\
(0.034)\end{array}$ & $\begin{array}{l}-0.003 \\
(0.161)\end{array}$ & $\begin{array}{c}0.006^{* * * *} \\
(0.002)\end{array}$ & $\begin{array}{l}0.002 * * \\
(0.042)\end{array}$ & $\begin{array}{l}-0.013^{*} \\
(0.058)\end{array}$ & $\begin{array}{c}-0.096^{* * * *} \\
(0.000)\end{array}$ & $\begin{array}{l}-0.008 \\
(0.180)\end{array}$ & $\begin{array}{l}-0.006 \\
(0.240)\end{array}$ \\
\hline CEO Compensation & $\begin{array}{l}-0.007 \\
(0.118)\end{array}$ & $\begin{array}{l}-0.001 \\
(0.299)\end{array}$ & $\begin{array}{l}-0.001 \\
(0.166)\end{array}$ & $\begin{array}{c}0.001 \\
(0.194)\end{array}$ & $\begin{array}{c}0.002 \\
(0.552)\end{array}$ & $\begin{array}{c}0.022 \\
(0.191)\end{array}$ & $\begin{array}{c}0.000 \\
(0.955)\end{array}$ & $\begin{array}{l}-0.000 \\
(0.951)\end{array}$ \\
\hline CEO Compensation & $\begin{array}{c}-0.017 * \\
(0.088)\end{array}$ & $\begin{array}{l}-0.001 \\
(0.683)\end{array}$ & $\begin{array}{c}0.004 * * \\
(0.034)\end{array}$ & $\begin{array}{c}-0.002 \\
(0.298)\end{array}$ & $\begin{array}{l}-0.009 \\
(0.217)\end{array}$ & $\begin{array}{c}-0.072 * * \\
(0.022)\end{array}$ & $\begin{array}{l}-0.009 \\
(0.193)\end{array}$ & $\begin{array}{l}-0.008 \\
(0.234)\end{array}$ \\
\hline Herfindhal Index & $\begin{array}{c}0.354 * * * \\
(0.004)\end{array}$ & $\begin{array}{c}-0.037 \\
(0.315)\end{array}$ & $\begin{array}{l}-0.011 \\
(0.643)\end{array}$ & $\begin{array}{c}0.027 \\
(0.209)\end{array}$ & $\begin{array}{c}0.350 * * * \\
(0.001)\end{array}$ & $\begin{array}{c}0.408 \\
(0.348)\end{array}$ & $\begin{array}{c}0.301 * * * \\
(0.002)\end{array}$ & $\begin{array}{c}0.283^{* * * *} \\
(0.003)\end{array}$ \\
\hline CEO Chara & & & & & & & & \\
\hline $\mathrm{Ln}(\mathrm{CEO}$ Tenure +1$)$ & $\begin{array}{c}-0.000 \\
(0.988)\end{array}$ & $\begin{array}{l}-0.003 * \\
(0.062)\end{array}$ & $\begin{array}{c}0.001 \\
(0.538)\end{array}$ & $\begin{array}{c}-0.001 * * \\
(0.040)\end{array}$ & $\begin{array}{c}-0.001 \\
(0.791)\end{array}$ & $\begin{array}{l}-0.003 \\
(0.857)\end{array}$ & $\begin{array}{c}-0.004 \\
(0.404)\end{array}$ & $\begin{array}{c}-0.004 \\
(0.319)\end{array}$ \\
\hline CEO Age & $\begin{array}{c}-0.064^{* *} \\
(0.038)\end{array}$ & $\begin{array}{c}-0.017 * * \\
(0.046)\end{array}$ & $\begin{array}{c}-0.016^{* *} \\
(0.016)\end{array}$ & $\begin{array}{l}-0.001 \\
(0.795)\end{array}$ & $\begin{array}{c}-0.042 \\
(0.101)\end{array}$ & $\begin{array}{c}0.067 \\
(0.431)\end{array}$ & $\begin{array}{l}-0.044^{*} \\
(0.060)\end{array}$ & $\begin{array}{c}-0.044 * * \\
(0.048)\end{array}$ \\
\hline $\operatorname{MBA}(0 / 1)$ & $\begin{array}{l}0.013^{*} \\
(0.089)\end{array}$ & $\begin{array}{l}-0.002 \\
(0.247)\end{array}$ & $\begin{array}{c}0.002 \\
(0.348)\end{array}$ & $\begin{array}{l}-0.001 \\
(0.476)\end{array}$ & $\begin{array}{l}-0.009 \\
(0.115)\end{array}$ & $\begin{array}{c}0.003 \\
(0.884)\end{array}$ & $\begin{array}{c}-0.009 * \\
(0.083)\end{array}$ & $\begin{array}{c}-0.009 * \\
(0.071)\end{array}$ \\
\hline Founder $(0 / 1)$ & $\begin{array}{c}0.010 \\
(0.443)\end{array}$ & $\begin{array}{l}-0.003 \\
(0.386)\end{array}$ & $\begin{array}{c}-0.005^{*} \\
(0.066)\end{array}$ & $\begin{array}{l}-0.003 \\
(0.165)\end{array}$ & $\begin{array}{l}0.019^{*} \\
(0.073)\end{array}$ & $\begin{array}{l}0.059^{*} \\
(0.082)\end{array}$ & $\begin{array}{l}0.017^{*} \\
(0.075)\end{array}$ & $\begin{array}{l}0.016^{*} \\
(0.077)\end{array}$ \\
\hline \# Functional Areas & $\begin{array}{c}-0.001 \\
(0.716)\end{array}$ & $\begin{array}{l}-0.001 \\
(0.357)\end{array}$ & $\begin{array}{c}0.001 \\
(0.457)\end{array}$ & $\begin{array}{l}-0.000 \\
(0.415)\end{array}$ & $\begin{array}{c}0.003 \\
(0.239)\end{array}$ & $\begin{array}{c}0.007 \\
(0.510)\end{array}$ & $\begin{array}{c}0.002 \\
(0.379)\end{array}$ & $\begin{array}{c}0.002 \\
(0.544)\end{array}$ \\
\hline $\begin{array}{l}\text { Has Finance } \\
\text { Background }(0 / 1)\end{array}$ & $\begin{array}{c}0.007 \\
(0.425)\end{array}$ & $\begin{array}{l}-0.004 \\
(0.161)\end{array}$ & $\begin{array}{c}-0.005^{* * *} \\
(0.002)\end{array}$ & $\begin{array}{l}-0.001 \\
(0.389)\end{array}$ & $\begin{array}{c}0.001 \\
(0.939)\end{array}$ & $\begin{array}{c}0.003 \\
(0.882)\end{array}$ & $\begin{array}{c}0.000 \\
(0.989)\end{array}$ & $\begin{array}{l}-0.000 \\
(0.954)\end{array}$ \\
\hline Constant & $\begin{array}{l}0.276^{*} \\
(0.054)\end{array}$ & $\begin{array}{c}0.127 * * * \\
(0.001)\end{array}$ & $\begin{array}{c}0.064^{* *} \\
(0.029)\end{array}$ & $\begin{array}{c}0.012 \\
(0.579)\end{array}$ & $\begin{array}{c}0.596 * * * \\
(0.000)\end{array}$ & $\begin{array}{l}0.925^{* *} \\
(0.014)\end{array}$ & $\begin{array}{c}0.596^{* * *} \\
(0.000)\end{array}$ & $\begin{array}{c}0.601 * * * \\
(0.000)\end{array}$ \\
\hline Year Dummies & Yes & Yes & Yes & Yes & Yes & Yes & Yes & Yes \\
\hline Industry Dummies & Yes & Ye & Yes & Ye & Ye & Ye & $\mathrm{Y}$ & Yes \\
\hline Observations & 4826 & 5029 & 4914 & 5074 & 4693 & 4693 & 4693 & 4693 \\
\hline R-squared & 0.572 & 0.527 & 0.768 & 0.635 & 0.632 & 0.448 & 0.653 & 0.651 \\
\hline Hansen's J-test & 0.764 & 0.5 & 0.340 & 0.7 & 0.184 & 0.755 & 0.147 & 0.135 \\
\hline $\begin{array}{l}\text { First Stage } F \text {-stat for } \\
\text { \#Employers }\end{array}$ & 140.21 & 158.59 & 91.53 & 110.44 & 78.15 & 115.47 & 71.28 & 71.17 \\
\hline $\begin{array}{l}\text { First Stage F-stat for \# } \\
\text { Homogeneity }\end{array}$ & oyers & ustry & 73.31 & & & & & \\
\hline
\end{tabular}


Table B.1.7: The Interaction of CEO Employment History and Pre-turnover Risk Level

This table presents IV/2SLS results for firm policies and risks after including an interaction term of CEO Employment history and the firm's pre-turnover risk-level. The dependent variables are listed at the top of each column. High Pre-turnover risk dummy equals one if the firm's pre-turnover Total Risk (Annualized Daily Stock Return Standard Deviation). Refer to Table 1 and Appendix A for variable definitions. Pre-turnover firm policies are the respective firm policies in the year before the CEO turnover year. Instrumental variables for \#Employers are the unemployment rate for the year when the CEO started his first fulltime job, non-business career dummy that equals one if the CEO had academic or government jobs, and the number of years the CEO has worked in his current firm's industry. The instrumental variable for CEO employment history*Industry Homogeneity in the R\&D regression is the unemployment rate described above multiplied by industry homogeneity. The predicted signs for the CEO employment history proxies are presented in parenthesis at the top of each column. I report $p$-values based on robust standard errors clustered at the firm level in parenthesis. ${ }^{* *}, * *$, and $*$ indicate significance at the 1,5 , and $10 \%$ levels, respectively.

\begin{tabular}{|c|c|c|c|c|c|c|c|c|}
\hline & Leverage & CAPEXP & $R \& D$ & Adv. & $\begin{array}{c}\text { Total Risk } \\
\text { (Ann. Daily } \\
\text { Stock } \\
\text { Return Std.) }\end{array}$ & $\begin{array}{l}\text { Market } \\
\text { Risk } \\
\text { (CAPM) }\end{array}$ & $\begin{array}{c}\text { Firm- } \\
\text { specific } \\
\text { Risk } \\
\text { (CAPM) }\end{array}$ & $\begin{array}{c}\text { Firm- } \\
\text { specific } \\
\text { Risk } \\
\text { (4- Factor) }\end{array}$ \\
\hline \#Employers & $\begin{array}{c}(+) \\
0.016^{* * *} \\
(0.003)\end{array}$ & $\begin{array}{c}(-) \\
-0.004 * * * \\
(0.004)\end{array}$ & $\begin{array}{c}(+) \\
-0.012^{* *} \\
(0.027)\end{array}$ & $\begin{array}{c}(+) \\
0.003^{*} \\
(0.065)\end{array}$ & $\begin{array}{c}(+) \\
0.005 \\
(0.108)\end{array}$ & $\begin{array}{c}+(+) \\
-0.008 \\
(0.476)\end{array}$ & $\begin{array}{c}(+) \\
0.006^{* *} \\
(0.027)\end{array}$ & $\begin{array}{c}(+) \\
0.007 * * \\
(0.011)\end{array}$ \\
\hline $\begin{array}{l}\text { \#Employers * Ind. } \\
\text { Homogeneity }\end{array}$ & & & & & & & & \\
\hline $\begin{array}{l}\text { \#Employers*High Pre- } \\
\text { turnover Risk }\end{array}$ & $\begin{array}{l}-0.014 \\
(0.362)\end{array}$ & $\begin{array}{c}0.001 \\
(0.832)\end{array}$ & $\begin{array}{l}-0.002 \\
(0.378)\end{array}$ & $\begin{array}{l}-0.012 \\
(0.119)\end{array}$ & $\begin{array}{l}-0.003 \\
(0.791)\end{array}$ & $\begin{array}{l}-0.002 \\
(0.957)\end{array}$ & $\begin{array}{l}-0.006 \\
(0.480)\end{array}$ & $\begin{array}{l}-0.006 \\
(0.509)\end{array}$ \\
\hline \multicolumn{9}{|l|}{ Firm Characteristics } \\
\hline Pre-turnover Policy & $\begin{array}{c}0.302 * * * \\
(0.000)\end{array}$ & $\begin{array}{c}0.301 * * * \\
(0.000)\end{array}$ & $\begin{array}{c}0.543 * * * \\
(0.000)\end{array}$ & $\begin{array}{c}0.545^{* * *} \\
(0.000)\end{array}$ & $\begin{array}{c}0.190^{* * *} \\
(0.000)\end{array}$ & $\begin{array}{c}0.189 * * * \\
(0.000)\end{array}$ & $\begin{array}{l}0.194 * * * \\
(0.000)\end{array}$ & $\begin{array}{c}0.190^{* * *} \\
(0.000)\end{array}$ \\
\hline $\ln$ (Total Sales) & $\begin{array}{c}0.022 * * * \\
(0.000)\end{array}$ & $\begin{array}{c}-0.002 * * \\
(0.024)\end{array}$ & $\begin{array}{c}-0.002 * * * \\
(0.006)\end{array}$ & $\begin{array}{l}0.001^{*} \\
(0.075)\end{array}$ & $\begin{array}{c}-0.019 * * * \\
(0.000)\end{array}$ & $\begin{array}{c}-0.031 * * * \\
(0.000)\end{array}$ & $\begin{array}{c}-0.019^{* * *} \\
(0.000)\end{array}$ & $\begin{array}{c}-0.019 * * * \\
(0.000)\end{array}$ \\
\hline Firm Age & $\begin{array}{l}-0.004 \\
(0.589)\end{array}$ & $\begin{array}{c}0.000 \\
(0.848)\end{array}$ & $\begin{array}{c}-0.003 * * * \\
(0.003)\end{array}$ & $\begin{array}{c}0.001 \\
(0.323)\end{array}$ & $\begin{array}{c}-0.020^{* * *} \\
(0.000)\end{array}$ & $\begin{array}{c}-0.063 * * * \\
(0.000)\end{array}$ & $\begin{array}{c}-0.016^{* * *} \\
(0.000)\end{array}$ & $\begin{array}{c}-0.015^{* * *} \\
(0.000)\end{array}$ \\
\hline $\begin{array}{l}\text { Operating Return on } \\
\text { Assets }\end{array}$ & $\begin{array}{c}-0.571 * * * \\
(0.000)\end{array}$ & & & & $\begin{array}{l}-0.281^{* * *} \\
(0.000)\end{array}$ & $\begin{array}{c}-0.609^{* * *} \\
(0.000)\end{array}$ & $\begin{array}{c}-0.228^{* * *} \\
(0.000)\end{array}$ & $\begin{array}{c}-0.210^{* * *} \\
(0.000)\end{array}$ \\
\hline Surplus Cash & & $\begin{array}{l}0.018^{* *} \\
(0.038)\end{array}$ & $\begin{array}{c}0.126^{* * *} \\
(0.000)\end{array}$ & $\begin{array}{l}-0.010 \\
(0.279)\end{array}$ & & & & \\
\hline Tobin's Q & $\begin{array}{c}-0.022 * * * \\
(0.000)\end{array}$ & $\begin{array}{c}0.003 * * * \\
(0.002)\end{array}$ & $\begin{array}{l}-0.001 \\
(0.543)\end{array}$ & $\begin{array}{c}0.001 * * * \\
(0.008)\end{array}$ & $\begin{array}{c}0.007 * * \\
(0.012)\end{array}$ & $\begin{array}{c}0.055^{* * *} \\
(0.000)\end{array}$ & $\begin{array}{l}0.005^{*} \\
(0.084)\end{array}$ & $\begin{array}{c}0.004 \\
(0.133)\end{array}$ \\
\hline R\&D/Total Assets & $\begin{array}{c}-0.383 * * * \\
(0.000)\end{array}$ & $\begin{array}{l}-0.033 \\
(0.147)\end{array}$ & & $\begin{array}{c}0.004 \\
(0.791)\end{array}$ & $\begin{array}{c}0.467 * * * \\
(0.000)\end{array}$ & $\begin{array}{c}1.023 * * * \\
(0.000)\end{array}$ & $\begin{array}{c}0.410 * * * \\
(0.000)\end{array}$ & $\begin{array}{c}0.386 * * * \\
(0.000)\end{array}$ \\
\hline Adv./Total Assets & & $\begin{array}{c}0.013 \\
(0.719)\end{array}$ & $\begin{array}{l}-0.018 \\
(0.611)\end{array}$ & & $\begin{array}{l}0.168 \\
(0.135)\end{array}$ & $\begin{array}{l}-0.127 \\
(0.729)\end{array}$ & $\begin{array}{l}0.189^{*} \\
(0.080)\end{array}$ & $\begin{array}{l}0.195^{*} \\
(0.066)\end{array}$ \\
\hline CAPEXP & & & $\begin{array}{l}-0.007 \\
(0.659)\end{array}$ & $\begin{array}{l}0.016^{*} \\
(0.085)\end{array}$ & $\begin{array}{c}0.284 * * * \\
(0.000)\end{array}$ & $\begin{array}{c}0.564 * * * \\
(0.008)\end{array}$ & $\begin{array}{c}0.240 * * * \\
(0.000)\end{array}$ & $\begin{array}{c}0.221 * * * \\
(0.000)\end{array}$ \\
\hline Leverage & & $\begin{array}{l}-0.012 \\
(0.113)\end{array}$ & $\begin{array}{c}0.010^{* *} \\
(0.022)\end{array}$ & $\begin{array}{l}-0.006^{*} \\
(0.066)\end{array}$ & $\begin{array}{c}0.070 * * * \\
(0.001)\end{array}$ & $\begin{array}{c}0.049 \\
(0.514)\end{array}$ & $\begin{array}{c}0.075^{* * * *} \\
(0.000)\end{array}$ & $\begin{array}{c}0.075^{* * *} \\
(0.000)\end{array}$ \\
\hline Industry Homogeneity & & & $\begin{array}{l}-0.151^{*} \\
(0.060)\end{array}$ & & & & & \\
\hline Capital & $\begin{array}{c}0.097 * * * \\
(0.001)\end{array}$ & & & & & & & \\
\hline Depr./Total Assets & $\begin{array}{c}0.025 \\
(0.890)\end{array}$ & & & & & & & \\
\hline
\end{tabular}


Table B.1.7 Continued

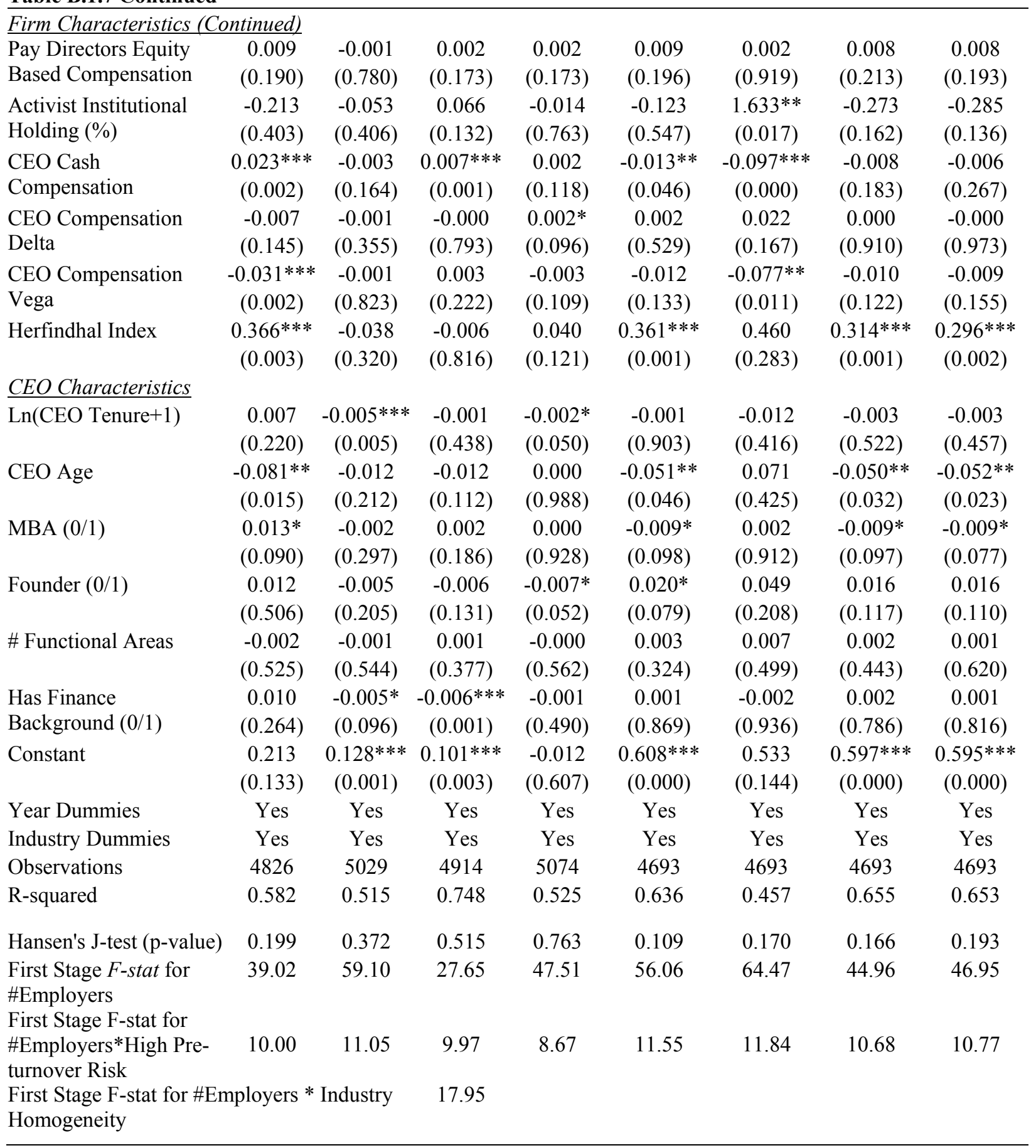




\section{Table B.1.8: A subsample with Board Size and the Insider Percentage Information}

This table presents IV/2SLS results for firm policies and risks for a subsample of firms with board size and insider ratio information. The dependent variables are listed at the top of each column. Refer to Table 1 and Appendix A for variable definitions. Pre-turnover firm policies are the respective firm policies in the year before the CEO turnover year. Instrumental variables for \#Employers are the unemployment rate for the year when the CEO started his first fulltime job, non-business career dummy that equals one if the CEO had academic or government jobs, and the number of years the CEO has worked in his current firm's industry. The instrumental variable for CEO employment history*Industry Homogeneity in the R\&D regression is the unemployment rate described above multiplied by industry homogeneity. The predicted signs for the CEO employment history proxies are presented in parenthesis at the top of each column. I report $p$-values based on robust standard errors clustered at the firm level in parenthesis. $* * *, * *$, and $*$ indicate significance at the 1,5 , and $10 \%$ levels, respectively.

\begin{tabular}{|c|c|c|c|c|c|c|c|c|}
\hline & Leverage & CAPEXP & $R \& D$ & Adv. & $\begin{array}{c}\text { Total Risk } \\
\text { (Ann. Daily } \\
\text { Stock } \\
\text { Return Std.) }\end{array}$ & $\begin{array}{c}\text { Market } \\
\text { Risk } \\
\text { (CAPM) }\end{array}$ & $\begin{array}{c}\text { Firm- } \\
\text { specific } \\
\text { Risk } \\
\text { (CAPM) }\end{array}$ & $\begin{array}{c}\text { Firm- } \\
\text { specific } \\
\text { Risk } \\
\text { (4- Factor) }\end{array}$ \\
\hline \#Employers & $\begin{array}{c}(+) \\
0.012 * * \\
(0.028)\end{array}$ & $\begin{array}{c}(-) \\
-0.004^{* * *} \\
(0.006)\end{array}$ & $\begin{array}{c}(+) \\
-0.011 * * \\
(0.026)\end{array}$ & $\begin{array}{c}(+) \\
0.001 * \\
(0.082)\end{array}$ & $\begin{array}{c}(+) \\
0.008^{* *} \\
(0.025)\end{array}$ & $\begin{array}{c}(+) \\
-0.005 \\
(0.708)\end{array}$ & $\begin{array}{c}(+) \\
0.009 * * * \\
(0.004)\end{array}$ & $\begin{array}{c}(+) \\
0.010^{* * *} \\
(0.001)\end{array}$ \\
\hline $\begin{array}{l}\text { \#Employers * Ind. } \\
\text { Homogeneity }\end{array}$ & & & $\begin{array}{l}0.044^{*} \\
(0.061)\end{array}$ & & & & & \\
\hline \multicolumn{9}{|l|}{ Firm Characteristics } \\
\hline Pre-turnover Policy & $\begin{array}{c}0.250^{* * *} \\
(0.000)\end{array}$ & $\begin{array}{c}0.292 * * * \\
(0.000)\end{array}$ & $\begin{array}{c}0.577 * * * \\
(0.000)\end{array}$ & $\begin{array}{c}0.550^{* * *} \\
(0.000)\end{array}$ & $\begin{array}{c}0.205^{* * *} \\
(0.000)\end{array}$ & $\begin{array}{c}0.157^{* * *} \\
(0.000)\end{array}$ & $\begin{array}{c}0.213^{* * *} \\
(0.000)\end{array}$ & $\begin{array}{l}0.209 * * * \\
(0.000)\end{array}$ \\
\hline $\ln$ (Total Sales) & $\begin{array}{c}0.020^{* * *} \\
(0.000)\end{array}$ & $\begin{array}{l}-0.002 * \\
(0.062)\end{array}$ & $\begin{array}{l}-0.001 \\
(0.111)\end{array}$ & $\begin{array}{c}0.001 \\
(0.183)\end{array}$ & $\begin{array}{c}-0.016 * * * \\
(0.000)\end{array}$ & $\begin{array}{l}-0.018^{*} \\
(0.090)\end{array}$ & $\begin{array}{c}-0.016 * * * \\
(0.000)\end{array}$ & $\begin{array}{c}-0.016^{* * *} \\
(0.000)\end{array}$ \\
\hline Firm Age & $\begin{array}{l}-0.009 \\
(0.234)\end{array}$ & $\begin{array}{c}0.000 \\
(0.814)\end{array}$ & $\begin{array}{c}-0.003 * * \\
(0.035)\end{array}$ & $\begin{array}{c}0.001 \\
(0.508)\end{array}$ & & $\begin{array}{c}-0.056^{* * *} \\
(0.002)\end{array}$ & & \\
\hline $\begin{array}{l}\text { Operating Return on } \\
\text { Assets }\end{array}$ & $\begin{array}{c}-0.563^{* * *} \\
(0.000)\end{array}$ & & & & $\begin{array}{c}-0.284 * * * \\
(0.000)\end{array}$ & $\begin{array}{c}-0.632 * * * \\
(0.000)\end{array}$ & $\begin{array}{c}-0.228 * * * \\
(0.000)\end{array}$ & $\begin{array}{c}-0.207 * * * \\
(0.000)\end{array}$ \\
\hline Surplus Cash & & $\begin{array}{l}0.016^{*} \\
(0.084)\end{array}$ & $\begin{array}{c}0.116^{* * *} \\
(0.000)\end{array}$ & $\begin{array}{l}-0.015 \\
(0.138)\end{array}$ & & & & \\
\hline Tobin's Q & $\begin{array}{c}-0.023^{* * *} \\
(0.000)\end{array}$ & $\begin{array}{l}0.003 * * * \\
(0.000)\end{array}$ & $\begin{array}{l}-0.000 \\
(0.831)\end{array}$ & $\begin{array}{c}0.002 * * * \\
(0.007)\end{array}$ & $\begin{array}{c}0.010^{* * *} \\
(0.001)\end{array}$ & $\begin{array}{c}0.072 * * * \\
(0.000)\end{array}$ & $\begin{array}{r}0.007 * * \\
(0.021)\end{array}$ & $\begin{array}{l}0.006 * * \\
(0.042)\end{array}$ \\
\hline R\&D/Total Assets & $\begin{array}{c}-0.366^{* * *} \\
(0.000)\end{array}$ & $\begin{array}{l}-0.042 * \\
(0.088)\end{array}$ & & $\begin{array}{l}-0.001 \\
(0.960)\end{array}$ & $\begin{array}{c}0.452 * * * \\
(0.000)\end{array}$ & $\begin{array}{c}1.082 * * * \\
(0.000)\end{array}$ & $\begin{array}{c}0.387 * * * \\
(0.000)\end{array}$ & $\begin{array}{c}0.368 * * * \\
(0.000)\end{array}$ \\
\hline Adv./Total Assets & & $\begin{array}{c}0.014 \\
(0.708)\end{array}$ & $\begin{array}{l}-0.033 \\
(0.408)\end{array}$ & & $\begin{array}{c}0.082 \\
(0.507)\end{array}$ & $\begin{array}{l}-0.448 \\
(0.271)\end{array}$ & $\begin{array}{c}0.114 \\
(0.327)\end{array}$ & $\begin{array}{c}0.121 \\
(0.295)\end{array}$ \\
\hline CAPEXP & & & $\begin{array}{l}-0.002 \\
(0.914)\end{array}$ & $\begin{array}{c}0.015 \\
(0.140)\end{array}$ & $\begin{array}{c}0.364 * * * \\
(0.000)\end{array}$ & $\begin{array}{c}0.724 * * * \\
(0.002)\end{array}$ & $\begin{array}{c}0.315^{* * * *} \\
(0.000)\end{array}$ & $\begin{array}{c}0.294 * * * \\
(0.000)\end{array}$ \\
\hline Leverage & & $\begin{array}{l}-0.010 \\
(0.206)\end{array}$ & $\begin{array}{c}0.005 \\
(0.322)\end{array}$ & $\begin{array}{l}-0.007 * \\
(0.058)\end{array}$ & $\begin{array}{c}0.066^{* * * *} \\
(0.006)\end{array}$ & $\begin{array}{c}0.030 \\
(0.722)\end{array}$ & $\begin{array}{c}0.069 * * * \\
(0.002)\end{array}$ & $\begin{array}{c}0.067 * * * \\
(0.002)\end{array}$ \\
\hline Industry Homogeneity & & & $\begin{array}{l}-0.125^{*} \\
(0.093)\end{array}$ & & & & & \\
\hline Capital Intensity & $\begin{array}{c}0.117 * * * \\
(0.000)\end{array}$ & & & & & & & \\
\hline Depr./Total Assets & $\begin{array}{l}-0.087 \\
(0.652)\end{array}$ & & & & & & & \\
\hline $\begin{array}{l}\text { Pay Director Equity- } \\
\text { based compensation }\end{array}$ & $\begin{array}{c}0.011 \\
(0.141)\end{array}$ & $\begin{array}{l}-0.002 \\
(0.457)\end{array}$ & $\begin{array}{c}0.002 \\
(0.213)\end{array}$ & $\begin{array}{c}0.002 \\
(0.122)\end{array}$ & $\begin{array}{l}0.016^{* *} \\
(0.045)\end{array}$ & $\begin{array}{c}0.010 \\
(0.706)\end{array}$ & $\begin{array}{l}0.013^{*} \\
(0.061)\end{array}$ & $\begin{array}{l}0.013 * * \\
(0.049)\end{array}$ \\
\hline
\end{tabular}


Table B.1.8 Continued

\begin{tabular}{|c|c|c|c|c|c|c|c|c|}
\hline \multicolumn{9}{|c|}{ Firm Characteristics (Continued) } \\
\hline $\begin{array}{l}\text { Activist Institutional } \\
\text { Holding (\%) }\end{array}$ & $\begin{array}{l}-0.182 \\
(0.498)\end{array}$ & $\begin{array}{l}-0.030 \\
(0.644)\end{array}$ & $\begin{array}{c}0.075 \\
(0.132)\end{array}$ & $\begin{array}{l}-0.024 \\
(0.607)\end{array}$ & $\begin{array}{l}-0.116 \\
(0.594)\end{array}$ & $\begin{array}{l}1.844 * * \\
(0.013)\end{array}$ & $\begin{array}{l}-0.277 \\
(0.173)\end{array}$ & $\begin{array}{l}-0.291 \\
(0.141)\end{array}$ \\
\hline $\begin{array}{l}\text { CEO Cash } \\
\text { Compensation }\end{array}$ & $\begin{array}{c}0.023^{* * *} \\
(0.005)\end{array}$ & $\begin{array}{l}-0.002 \\
(0.361)\end{array}$ & $\begin{array}{c}0.007 * * * \\
(0.005)\end{array}$ & $\begin{array}{c}0.002 \\
(0.119)\end{array}$ & $\begin{array}{c}-0.028 * * * \\
(0.001)\end{array}$ & $\begin{array}{c}-0.150^{* * * *} \\
(0.000)\end{array}$ & $\begin{array}{c}-0.019 * * * \\
(0.009)\end{array}$ & $\begin{array}{c}-0.016^{* *} \\
(0.018)\end{array}$ \\
\hline $\begin{array}{l}\text { CEO Compensation } \\
\text { Delta }\end{array}$ & $\begin{array}{l}-0.004 \\
(0.390)\end{array}$ & $\begin{array}{l}-0.001 \\
(0.372)\end{array}$ & $\begin{array}{l}-0.001 \\
(0.561)\end{array}$ & $\begin{array}{c}0.001 \\
(0.319)\end{array}$ & $\begin{array}{c}0.002 \\
(0.704)\end{array}$ & $\begin{array}{c}0.017 \\
(0.363)\end{array}$ & $\begin{array}{l}-0.000 \\
(0.935)\end{array}$ & $\begin{array}{l}-0.001 \\
(0.862)\end{array}$ \\
\hline $\begin{array}{l}\text { CEO Compensation } \\
\text { Vega }\end{array}$ & $\begin{array}{c}-0.020 * \\
(0.060)\end{array}$ & $\begin{array}{l}-0.002 \\
(0.412)\end{array}$ & $\begin{array}{l}0.004^{*} \\
(0.076)\end{array}$ & $\begin{array}{l}-0.002 \\
(0.198)\end{array}$ & $\begin{array}{l}-0.008 \\
(0.411)\end{array}$ & $\begin{array}{c}-0.076^{* *} \\
(0.040)\end{array}$ & $\begin{array}{l}-0.008 \\
(0.340)\end{array}$ & $\begin{array}{l}-0.007 \\
(0.381)\end{array}$ \\
\hline Board Size & $\begin{array}{c}0.002 \\
(0.346)\end{array}$ & $\begin{array}{c}0.000 \\
(0.961)\end{array}$ & $\begin{array}{l}-0.000 \\
(0.337)\end{array}$ & $\begin{array}{l}-0.000 \\
(0.916)\end{array}$ & $\begin{array}{c}-0.004 * * * \\
(0.003)\end{array}$ & $\begin{array}{l}-0.009^{*} \\
(0.090)\end{array}$ & $\begin{array}{c}-0.004 * * * \\
(0.009)\end{array}$ & $\begin{array}{c}-0.003 * * \\
(0.021)\end{array}$ \\
\hline Insider Ratio & $\begin{array}{l}-0.015 \\
(0.564)\end{array}$ & $\begin{array}{l}-0.010 \\
(0.165)\end{array}$ & $\begin{array}{l}-0.002 \\
(0.779)\end{array}$ & $\begin{array}{l}-0.003 \\
(0.372)\end{array}$ & $\begin{array}{c}0.023 \\
(0.257)\end{array}$ & $\begin{array}{c}0.034 \\
(0.651)\end{array}$ & $\begin{array}{c}0.024 \\
(0.176)\end{array}$ & $\begin{array}{c}0.023 \\
(0.187)\end{array}$ \\
\hline Herfindhal Index & $\begin{array}{l}-0.051 \\
(0.631)\end{array}$ & $\begin{array}{l}-0.066 \\
(0.124)\end{array}$ & $\begin{array}{l}-0.006 \\
(0.826)\end{array}$ & $\begin{array}{l}0.049^{*} \\
(0.062)\end{array}$ & $\begin{array}{c}0.501 * * * \\
(0.000)\end{array}$ & $\begin{array}{l}0.949^{*} \\
(0.050)\end{array}$ & $\begin{array}{c}0.430^{* * * *} \\
(0.000)\end{array}$ & $\begin{array}{c}0.405^{* * *} \\
(0.000)\end{array}$ \\
\hline \multicolumn{9}{|l|}{$\underline{\text { CEO Characteristics }}$} \\
\hline $\operatorname{Ln}(\mathrm{CEO}$ Tenure +1$)$ & $\begin{array}{c}0.003 \\
(0.591)\end{array}$ & $\begin{array}{c}-0.004 * * \\
(0.040)\end{array}$ & $\begin{array}{l}-0.000 \\
(0.952)\end{array}$ & $\begin{array}{c}-0.002 * * \\
(0.034)\end{array}$ & $\begin{array}{l}-0.006 \\
(0.269)\end{array}$ & $\begin{array}{l}-0.005 \\
(0.754)\end{array}$ & $\begin{array}{l}-0.007 \\
(0.159)\end{array}$ & $\begin{array}{l}-0.007 \\
(0.143)\end{array}$ \\
\hline CEO Age & $\begin{array}{c}-0.077^{* *} \\
(0.024)\end{array}$ & $\begin{array}{l}-0.009 \\
(0.403)\end{array}$ & $\begin{array}{l}-0.010 \\
(0.203)\end{array}$ & $\begin{array}{l}-0.003 \\
(0.525)\end{array}$ & $\begin{array}{c}-0.068^{* *} \\
(0.016)\end{array}$ & $\begin{array}{c}0.075 \\
(0.454)\end{array}$ & $\begin{array}{c}-0.066^{* *} \\
(0.010)\end{array}$ & $\begin{array}{c}-0.067^{* * *} \\
(0.007)\end{array}$ \\
\hline $\operatorname{MBA}(0 / 1)$ & $\begin{array}{c}0.012 \\
(0.128)\end{array}$ & $\begin{array}{l}-0.002 \\
(0.411)\end{array}$ & $\begin{array}{c}0.002 \\
(0.268)\end{array}$ & $\begin{array}{l}-0.001 \\
(0.329)\end{array}$ & $\begin{array}{l}-0.009 \\
(0.135)\end{array}$ & $\begin{array}{c}0.008 \\
(0.704)\end{array}$ & $\begin{array}{l}-0.010^{*} \\
(0.077)\end{array}$ & $\begin{array}{l}-0.010^{*} \\
(0.057)\end{array}$ \\
\hline Founder $(0 / 1)$ & $\begin{array}{c}0.011 \\
(0.460)\end{array}$ & $\begin{array}{l}-0.004 \\
(0.284)\end{array}$ & $\begin{array}{l}-0.005 \\
(0.131)\end{array}$ & $\begin{array}{l}-0.002 \\
(0.338)\end{array}$ & $\begin{array}{r}0.027^{* *} \\
(0.021)\end{array}$ & $\begin{array}{l}0.068^{*} \\
(0.078)\end{array}$ & $\begin{array}{c}0.024 * * \\
(0.020)\end{array}$ & $\begin{array}{c}0.024^{* *} \\
(0.018)\end{array}$ \\
\hline \# Functional Areas & $\begin{array}{l}-0.003 \\
(0.481)\end{array}$ & $\begin{array}{l}-0.000 \\
(0.676)\end{array}$ & $\begin{array}{c}0.001 \\
(0.328)\end{array}$ & $\begin{array}{l}-0.001 \\
(0.227)\end{array}$ & $\begin{array}{l}0.005^{*} \\
(0.095)\end{array}$ & $\begin{array}{c}0.012 \\
(0.277)\end{array}$ & $\begin{array}{c}0.004 \\
(0.179)\end{array}$ & $\begin{array}{c}0.003 \\
(0.297)\end{array}$ \\
\hline $\begin{array}{l}\text { Has Finance } \\
\text { Background }(0 / 1)\end{array}$ & $\begin{array}{c}0.010 \\
(0.315)\end{array}$ & $\begin{array}{l}-0.006^{*} \\
(0.053)\end{array}$ & $\begin{array}{c}-0.007 * * * \\
(0.000)\end{array}$ & $\begin{array}{l}-0.001 \\
(0.478)\end{array}$ & $\begin{array}{l}-0.000 \\
(0.965)\end{array}$ & $\begin{array}{c}0.006 \\
(0.807)\end{array}$ & $\begin{array}{c}0.000 \\
(0.986)\end{array}$ & $\begin{array}{c}0.000 \\
(0.980)\end{array}$ \\
\hline Constant & $\begin{array}{c}0.390 * * * \\
(0.003)\end{array}$ & $\begin{array}{c}0.154^{* * * *} \\
(0.000)\end{array}$ & $\begin{array}{c}0.088^{* *} \\
(0.010)\end{array}$ & $\begin{array}{c}0.004 \\
(0.819)\end{array}$ & $\begin{array}{c}0.530^{* * *} \\
(0.000)\end{array}$ & $\begin{array}{c}0.400 \\
(0.323)\end{array}$ & $\begin{array}{c}0.562 * * * \\
(0.000)\end{array}$ & $\begin{array}{c}0.564^{* * * *} \\
(0.000)\end{array}$ \\
\hline Year Dummies & Yes & Yes & Yes & Yes & Yes & Yes & Yes & Yes \\
\hline Industry Dummies & Yes & Yes & Yes & Yes & Yes & Yes & Yes & Yes \\
\hline Observations & 3470 & 3614 & 3529 & 3685 & 3375 & 3369 & 3377 & 3377 \\
\hline R-squared & 0.572 & 0.505 & 0.763 & 0.634 & 0.640 & 0.446 & 0.662 & 0.661 \\
\hline Hansen's J-test ( $p$-value) & 0.291 & 0.914 & 0.487 & 0.871 & 0.238 & 0.756 & 0.268 & 0.327 \\
\hline $\begin{array}{l}\text { First Stage } F \text {-stat for } \\
\text { \#Employers } \\
\text { First Stage F-stat for \#En } \\
\text { Homogeneity }\end{array}$ & $\begin{array}{l}38.22 \\
\text { mployers * }\end{array}$ & $\begin{array}{r}53.96 \\
\text { Industry }\end{array}$ & $\begin{array}{l}39.39 \\
25.19\end{array}$ & 45.41 & 60.76 & 75.51 & 59.93 & 60.06 \\
\hline
\end{tabular}




\section{Table B.1.9: Include an Insider Dummy as an additional control variable}

This table presents IV/2SLS results for firm policies and risks after including an insider dummy as an additional control variable. The dependent variables are listed at the top of each column. Refer to Table 1 and Appendix A for variable definitions. Pre-turnover firm policies are the respective firm policies in the year before the CEO turnover year. Instrumental variables for \#Employers are the unemployment rate for the year when the CEO started his first fulltime job, non-business career dummy that equals one if the CEO had academic or government jobs, and the number of years the CEO has worked in his current firm's industry. The instrumental variable for CEO employment history*Industry Homogeneity in the R\&D regression is the unemployment rate described above multiplied by industry homogeneity. The predicted signs for the CEO employment history proxies are presented in parenthesis at the top of each column. I report $p$-values based on robust standard errors clustered at the firm level in parenthesis. $* * *, * *$, and $*$ indicate significance at the 1,5 , and $10 \%$ levels, respectively.

\begin{tabular}{|c|c|c|c|c|c|c|c|c|}
\hline & Leverage & CAPEXP & $R \& D$ & Adv. & $\begin{array}{c}\text { Total Risk } \\
\text { (Ann. Daily } \\
\text { Stock } \\
\text { Return Std.) }\end{array}$ & $\begin{array}{c}\text { Market } \\
\text { Risk } \\
\text { (CAPM) }\end{array}$ & $\begin{array}{c}\text { Firm- } \\
\text { specific } \\
\text { Risk } \\
\text { (CAPM) }\end{array}$ & $\begin{array}{c}\text { Firm- } \\
\text { specific } \\
\text { Risk } \\
\text { (4- Factor) }\end{array}$ \\
\hline \#Employers & $\begin{array}{c}(+) \\
0.015^{* *} \\
(0.048)\end{array}$ & $\begin{array}{c}(-) \\
-0.004^{* *} \\
(0.036)\end{array}$ & $\begin{array}{c}(+) \\
-0.015^{* * *} \\
(0.009)\end{array}$ & $\begin{array}{c}(+) \\
0.002 * \\
(0.091)\end{array}$ & $\begin{array}{c}(+) \\
0.004 \\
(0.282)\end{array}$ & $\begin{array}{c}(+) \\
-0.020 \\
(0.212)\end{array}$ & $\begin{array}{c}(+) \\
0.006^{*} \\
(0.090)\end{array}$ & $\begin{array}{c}+(+) \\
0.007^{* *} \\
(0.045)\end{array}$ \\
\hline $\begin{array}{l}\text { \#Employers * Ind. } \\
\text { Homogeneity }\end{array}$ & & & $\begin{array}{l}0.058 * * \\
(0.033)\end{array}$ & & & & & \\
\hline \multicolumn{9}{|l|}{ Firm Characteristics } \\
\hline Pre-turnover Policy & $\begin{array}{c}0.260^{* * *} \\
(0.000)\end{array}$ & $\begin{array}{c}0.302 * * * \\
(0.000)\end{array}$ & $\begin{array}{c}0.555^{* * *} \\
(0.000)\end{array}$ & $\begin{array}{c}0.543 * * * \\
(0.000)\end{array}$ & $\begin{array}{c}0.199 * * * \\
(0.000)\end{array}$ & $\begin{array}{c}0.192 * * * \\
(0.000)\end{array}$ & $\begin{array}{c}0.204^{* * *} \\
(0.000)\end{array}$ & $\begin{array}{l}0.199 * * * \\
(0.000)\end{array}$ \\
\hline $\ln$ (Total Sales) & $\begin{array}{c}0.021^{* * *} \\
(0.000)\end{array}$ & $\begin{array}{c}-0.002 * * \\
(0.026)\end{array}$ & $\begin{array}{c}-0.002 * * \\
(0.040)\end{array}$ & $\begin{array}{l}0.001 * \\
(0.065)\end{array}$ & $\begin{array}{c}-0.019 * * * \\
(0.000)\end{array}$ & $\begin{array}{c}-0.032 * * * \\
(0.000)\end{array}$ & $\begin{array}{c}-0.020 * * * \\
(0.000)\end{array}$ & $\begin{array}{c}-0.019 * * * \\
(0.000)\end{array}$ \\
\hline Firm Age & $\begin{array}{l}-0.005 \\
(0.471)\end{array}$ & $\begin{array}{l}0.001 \\
(0.775)\end{array}$ & $\begin{array}{c}-0.003^{* * *} \\
(0.008)\end{array}$ & $\begin{array}{c}0.001 \\
(0.330)\end{array}$ & $\begin{array}{c}-0.020^{* * *} \\
(0.000)\end{array}$ & $\begin{array}{c}-0.064 * * * \\
(0.000)\end{array}$ & $\begin{array}{c}-0.017 * * * \\
(0.000)\end{array}$ & $\begin{array}{c}-0.016^{* * *} \\
(0.000)\end{array}$ \\
\hline $\begin{array}{l}\text { Operating Return on } \\
\text { Assets }\end{array}$ & $\begin{array}{c}-0.575^{* * *} \\
(0.000)\end{array}$ & & & & $\begin{array}{c}-0.295 * * * \\
(0.000)\end{array}$ & $\begin{array}{c}-0.622 * * * \\
(0.000)\end{array}$ & $\begin{array}{c}-0.240 * * * \\
(0.000)\end{array}$ & $\begin{array}{c}-0.220 * * * \\
(0.000)\end{array}$ \\
\hline Surplus Cash & & $\begin{array}{c}0.020^{* *} \\
(0.018)\end{array}$ & $\begin{array}{c}0.119^{* * *} \\
(0.000)\end{array}$ & $\begin{array}{l}-0.011 \\
(0.251)\end{array}$ & & & & \\
\hline Tobin's Q & $\begin{array}{c}-0.022 * * * \\
(0.000)\end{array}$ & $\begin{array}{c}0.003 * * * \\
(0.001)\end{array}$ & $\begin{array}{l}-0.000 \\
(0.749)\end{array}$ & $(0.010)$ & $\begin{array}{c}0.008^{* * *} \\
(0.004)\end{array}$ & $\begin{array}{c}0.057 * * * \\
(0.000)\end{array}$ & $\begin{array}{r}0.005^{* *} \\
(0.040)\end{array}$ & $\begin{array}{l}0.004^{*} \\
(0.075)\end{array}$ \\
\hline R\&D/Total Assets & $\begin{array}{c}-0.332 * * * \\
(0.000)\end{array}$ & $\begin{array}{l}-0.040^{*} \\
(0.081)\end{array}$ & & $\begin{array}{c}0.005 \\
(0.727)\end{array}$ & $\begin{array}{c}0.493 * * * \\
(0.000)\end{array}$ & $\begin{array}{c}1.022 * * * \\
(0.000)\end{array}$ & $\begin{array}{l}0.432 * * * \\
(0.000)\end{array}$ & $\begin{array}{c}0.405^{* * *} \\
(0.000)\end{array}$ \\
\hline Adv./Total Assets & & $\begin{array}{c}0.017 \\
(0.635)\end{array}$ & $\begin{array}{l}-0.031 \\
(0.437)\end{array}$ & & $\begin{array}{c}0.145 \\
(0.200)\end{array}$ & $\begin{array}{l}-0.123 \\
(0.743)\end{array}$ & $\begin{array}{c}0.169 \\
(0.116)\end{array}$ & $\begin{array}{l}0.176^{*} \\
(0.097)\end{array}$ \\
\hline CAPEXP & & & $\begin{array}{l}-0.003 \\
(0.886)\end{array}$ & $\begin{array}{l}0.016^{*} \\
(0.094)\end{array}$ & $\begin{array}{c}0.302 * * * \\
(0.000)\end{array}$ & $\begin{array}{c}0.583^{* * *} \\
(0.006)\end{array}$ & $\begin{array}{c}0.255^{* * * *} \\
(0.000)\end{array}$ & $\begin{array}{c}0.236^{* * * *} \\
(0.000)\end{array}$ \\
\hline Leverage & & $\begin{array}{l}-0.012 \\
(0.116)\end{array}$ & $\begin{array}{c}0.005 \\
(0.324)\end{array}$ & $\begin{array}{l}-0.007 * \\
(0.057)\end{array}$ & $\begin{array}{c}0.072 * * * \\
(0.001)\end{array}$ & $\begin{array}{c}0.056 \\
(0.454)\end{array}$ & $\begin{array}{c}0.076^{* * *} \\
(0.000)\end{array}$ & $\begin{array}{l}0.076^{* * * *} \\
(0.000)\end{array}$ \\
\hline Industry Homogeneity & & & $\begin{array}{c}-0.173^{* *} \\
(0.041)\end{array}$ & & & & & \\
\hline Capital Intensity & $\begin{array}{c}0.121 * * * \\
(0.000)\end{array}$ & & & & & & & \\
\hline Depr./Total Assets & $\begin{array}{l}-0.128 \\
(0.488)\end{array}$ & & & & & & & \\
\hline $\begin{array}{l}\text { Pay Director Equity- } \\
\text { based compensation }\end{array}$ & $\begin{array}{c}0.011 \\
(0.114)\end{array}$ & $\begin{array}{c}-0.001 \\
(0.778) \\
\end{array}$ & $\begin{array}{c}0.002 \\
(0.177)\end{array}$ & $\begin{array}{c}0.002 \\
(0.107)\end{array}$ & $\begin{array}{c}0.009 \\
(0.177)\end{array}$ & $\begin{array}{c}0.004 \\
(0.880)\end{array}$ & $\begin{array}{c}0.008 \\
(0.198)\end{array}$ & $\begin{array}{c}0.008 \\
(0.176)\end{array}$ \\
\hline
\end{tabular}


Table B.1.9 Continued

\begin{tabular}{|c|c|c|c|c|c|c|c|c|}
\hline \multicolumn{9}{|c|}{ Firm Characteristics (Continued) } \\
\hline $\begin{array}{l}\text { Activist Institutional } \\
\text { Holding (\%) }\end{array}$ & $\begin{array}{l}-0.268 \\
(0.305)\end{array}$ & $\begin{array}{l}-0.061 \\
(0.340)\end{array}$ & $\begin{array}{c}0.060 \\
(0.180)\end{array}$ & $\begin{array}{l}-0.012 \\
(0.756)\end{array}$ & $\begin{array}{l}-0.139 \\
(0.497)\end{array}$ & $\begin{array}{l}1.506^{* *} \\
(0.031)\end{array}$ & $\begin{array}{l}-0.293 \\
(0.135)\end{array}$ & $\begin{array}{l}-0.304 \\
(0.113)\end{array}$ \\
\hline $\begin{array}{l}\text { CEO Cash } \\
\text { Compensation }\end{array}$ & $\begin{array}{c}0.017 * * \\
(0.025)\end{array}$ & $\begin{array}{l}-0.003 \\
(0.150)\end{array}$ & $\begin{array}{c}0.007 * * * \\
(0.002)\end{array}$ & $\begin{array}{l}0.002 * * \\
(0.033)\end{array}$ & $\begin{array}{c}-0.015^{* *} \\
(0.027)\end{array}$ & $\begin{array}{c}-0.102 * * * \\
(0.000)\end{array}$ & $\begin{array}{l}-0.009 \\
(0.122)\end{array}$ & $\begin{array}{l}-0.007 \\
(0.191)\end{array}$ \\
\hline $\begin{array}{l}\text { CEO Compensation } \\
\text { Delta }\end{array}$ & $\begin{array}{l}-0.006 \\
(0.168)\end{array}$ & $\begin{array}{l}-0.001 \\
(0.361)\end{array}$ & $\begin{array}{l}-0.001 \\
(0.672)\end{array}$ & $\begin{array}{c}0.001 \\
(0.209)\end{array}$ & $\begin{array}{c}0.002 \\
(0.619)\end{array}$ & $\begin{array}{c}0.021 \\
(0.216)\end{array}$ & $\begin{array}{l}-0.000 \\
(0.951)\end{array}$ & $\begin{array}{l}-0.001 \\
(0.855)\end{array}$ \\
\hline $\begin{array}{l}\text { CEO Compensation } \\
\text { Vega }\end{array}$ & $\begin{array}{c}-0.020 * * \\
(0.036)\end{array}$ & $\begin{array}{l}-0.001 \\
(0.783)\end{array}$ & $\begin{array}{c}0.003 \\
(0.165)\end{array}$ & $\begin{array}{l}-0.002 \\
(0.249)\end{array}$ & $\begin{array}{l}-0.010 \\
(0.205)\end{array}$ & $\begin{array}{c}-0.071 * * \\
(0.025)\end{array}$ & $\begin{array}{l}-0.009 \\
(0.188)\end{array}$ & $\begin{array}{l}-0.008 \\
(0.228)\end{array}$ \\
\hline Herfindhal Index & $\begin{array}{c}0.340^{* * *} \\
(0.005)\end{array}$ & $\begin{array}{l}-0.038 \\
(0.317)\end{array}$ & $\begin{array}{l}-0.006 \\
(0.810)\end{array}$ & $\begin{array}{c}0.028 \\
(0.201)\end{array}$ & $\begin{array}{c}0.358^{* * *} \\
(0.001)\end{array}$ & $\begin{array}{c}0.389 \\
(0.371)\end{array}$ & $\begin{array}{c}0.310^{* * *} \\
(0.002)\end{array}$ & $\begin{array}{c}0.292^{* * *} \\
(0.003)\end{array}$ \\
\hline \multicolumn{9}{|l|}{ CEO Characteristics } \\
\hline Insider $(0 / 1)$ & $\begin{array}{c}0.017 \\
(0.204)\end{array}$ & $\begin{array}{l}-0.001 \\
(0.874)\end{array}$ & $\begin{array}{l}-0.006^{*} \\
(0.070)\end{array}$ & $\begin{array}{c}0.001 \\
(0.546)\end{array}$ & $\begin{array}{l}-0.009 \\
(0.284)\end{array}$ & $\begin{array}{l}-0.048 \\
(0.146)\end{array}$ & $\begin{array}{l}-0.006 \\
(0.444)\end{array}$ & $\begin{array}{l}-0.004 \\
(0.552)\end{array}$ \\
\hline Ln(CEO Tenure+1) & $\begin{array}{c}0.006 \\
(0.314)\end{array}$ & $\begin{array}{c}-0.004 * * \\
(0.017)\end{array}$ & $\begin{array}{l}-0.001 \\
(0.515)\end{array}$ & $\begin{array}{l}-0.001 \\
(0.195)\end{array}$ & $\begin{array}{l}-0.000 \\
(0.922)\end{array}$ & $\begin{array}{l}-0.006 \\
(0.679)\end{array}$ & $\begin{array}{l}-0.002 \\
(0.570)\end{array}$ & $\begin{array}{l}-0.003 \\
(0.496)\end{array}$ \\
\hline CEO Age & $\begin{array}{c}-0.082 * * \\
(0.016)\end{array}$ & $\begin{array}{l}-0.011 \\
(0.251)\end{array}$ & $\begin{array}{l}-0.010 \\
(0.215)\end{array}$ & $\begin{array}{l}-0.004 \\
(0.390)\end{array}$ & $\begin{array}{c}-0.058^{* *} \\
(0.024)\end{array}$ & $\begin{array}{c}0.093 \\
(0.304)\end{array}$ & $\begin{array}{c}-0.058^{* *} \\
(0.012)\end{array}$ & $\begin{array}{c}-0.059 * * * \\
(0.008)\end{array}$ \\
\hline $\operatorname{MBA}(0 / 1)$ & $\begin{array}{l}0.015^{*} \\
(0.058)\end{array}$ & $\begin{array}{l}-0.002 \\
(0.314)\end{array}$ & $\begin{array}{c}0.002 \\
(0.235)\end{array}$ & $\begin{array}{l}-0.001 \\
(0.393)\end{array}$ & $\begin{array}{l}-0.010^{*} \\
(0.076)\end{array}$ & $\begin{array}{c}0.004 \\
(0.853)\end{array}$ & $\begin{array}{l}-0.010^{*} \\
(0.061)\end{array}$ & $\begin{array}{c}-0.010^{* *} \\
(0.050)\end{array}$ \\
\hline Founder $(0 / 1)$ & $\begin{array}{c}0.013 \\
(0.356)\end{array}$ & $\begin{array}{l}-0.005 \\
(0.185)\end{array}$ & $\begin{array}{l}-0.004 \\
(0.193)\end{array}$ & $\begin{array}{l}-0.002 \\
(0.362)\end{array}$ & $\begin{array}{c}0.024 * * \\
(0.027)\end{array}$ & $\begin{array}{c}0.054 \\
(0.131)\end{array}$ & $\begin{array}{c}0.022 * * \\
(0.027)\end{array}$ & $\begin{array}{c}0.021 * * \\
(0.025)\end{array}$ \\
\hline \# Functional Areas & $\begin{array}{l}-0.002 \\
(0.586)\end{array}$ & $\begin{array}{l}-0.001 \\
(0.563)\end{array}$ & $\begin{array}{c}0.001 \\
(0.337)\end{array}$ & $\begin{array}{l}-0.001 \\
(0.318)\end{array}$ & $\begin{array}{c}0.003 \\
(0.330)\end{array}$ & $\begin{array}{c}0.008 \\
(0.446)\end{array}$ & $\begin{array}{c}0.002 \\
(0.487)\end{array}$ & $\begin{array}{c}0.001 \\
(0.676)\end{array}$ \\
\hline $\begin{array}{l}\text { Has Finance } \\
\text { Background }(0 / 1)\end{array}$ & $\begin{array}{c}0.010 \\
(0.287)\end{array}$ & $\begin{array}{l}-0.004 \\
(0.101)\end{array}$ & $\begin{array}{c}-0.006^{* * *} \\
(0.001)\end{array}$ & $\begin{array}{l}-0.001 \\
(0.412)\end{array}$ & $\begin{array}{c}0.001 \\
(0.838)\end{array}$ & $\begin{array}{c}0.003 \\
(0.883)\end{array}$ & $\begin{array}{c}0.001 \\
(0.814)\end{array}$ & $\begin{array}{c}0.001 \\
(0.851)\end{array}$ \\
\hline Constant & $\begin{array}{l}0.248^{*} \\
(0.086)\end{array}$ & $\begin{array}{c}0.131 * * * \\
(0.000)\end{array}$ & $\begin{array}{c}0.109^{* * *} \\
(0.001)\end{array}$ & $\begin{array}{c}0.007 \\
(0.691)\end{array}$ & $\begin{array}{c}0.572 * * * \\
(0.000)\end{array}$ & $\begin{array}{l}0.624^{*} \\
(0.087)\end{array}$ & $\begin{array}{c}0.575^{* * *} \\
(0.000)\end{array}$ & $\begin{array}{c}0.572^{* * *} \\
(0.000)\end{array}$ \\
\hline Year Dummies & Yes & Yes & Yes & Yes & Yes & Yes & Yes & Yes \\
\hline Industry Dummies & Yes & Yes & Yes & Yes & Yes & Yes & Yes & Yes \\
\hline Observations & 4826 & 5029 & 4914 & 5074 & 4693 & 4693 & 4693 & 4693 \\
\hline R-squared & 0.570 & 0.513 & 0.740 & 0.631 & 0.634 & 0.450 & 0.654 & 0.651 \\
\hline Hansen's J-test (p-value) & 0.146 & 0.851 & 0.297 & 0.631 & 0.12 & 0.732 & 0.119 & 0.148 \\
\hline $\begin{array}{l}\text { First Stage } F \text {-stat for } \\
\text { \#Employers }\end{array}$ & 22.09 & 36.63 & 24.46 & 30.69 & 39.39 & 43.39 & 39.27 & 39.42 \\
\hline $\begin{array}{l}\text { First Stage F-stat for \#Em } \\
\text { Homogeneity }\end{array}$ & nployers ' & ndustry & 17.59 & & & & & \\
\hline
\end{tabular}




\section{Table B.1.10: Excluding the Herfindhal Index}

This table presents IV/2SLS results for firm policies and risk, excluding Herfindhal index as an additional control variable. The dependent variables are listed at the top of each column. Refer to Table 1 and Appendix A for variable definitions. Pre-turnover firm policies are the respective firm policies in the year before the CEO turnover year. Instrumental variables for \#Employers are the unemployment rate for the year when the CEO started his first fulltime job, non-business career dummy that equals one if the CEO had academic or government jobs, and the number of years the CEO has worked in his current firm's industry. The instrumental variable for CEO employment history*Industry Homogeneity in the R\&D regression is the unemployment rate described above multiplied by industry homogeneity. The predicted signs for the CEO employment history proxies are presented in parenthesis at the top of each column. I report $p$-values based on robust standard errors clustered at the firm level in parenthesis. $* * *, * *$, and $*$ indicate significance at the 1,5 , and $10 \%$ levels, respectively.

\begin{tabular}{|c|c|c|c|c|c|c|c|c|}
\hline & Leverage & CAPEXP & R\&D & Adv. & $\begin{array}{c}\text { Total Risk } \\
\text { (Ann. Daily } \\
\text { Stock } \\
\text { Return Std.) }\end{array}$ & $\begin{array}{c}\text { Market } \\
\text { Risk } \\
\text { (CAPM) }\end{array}$ & $\begin{array}{c}\text { Firm- } \\
\text { specific } \\
\text { Risk } \\
\text { (CAPM) }\end{array}$ & $\begin{array}{c}\text { Firm- } \\
\text { specific } \\
\text { Risk } \\
\text { (4- Factor) }\end{array}$ \\
\hline \#Employers & $\begin{array}{c}(+) \\
0.011^{* *} \\
(0.049)\end{array}$ & $\begin{array}{c}(-) \\
-0.004^{* * *} \\
(0.005)\end{array}$ & $\begin{array}{c}(+) \\
-0.013^{* *} \\
(0.016)\end{array}$ & $\begin{array}{c}(+) \\
0.001^{*} \\
(0.073)\end{array}$ & $\begin{array}{c}(+) \\
0.007^{* *} \\
(0.041)\end{array}$ & $\begin{array}{c}(+) \\
-0.008 \\
(0.511)\end{array}$ & $\begin{array}{c}(+) \\
0.007 * * * \\
(0.010)\end{array}$ & $\begin{array}{c}(+) \\
0.008^{* * *} \\
(0.004)\end{array}$ \\
\hline $\begin{array}{l}\text { \#Employers * Ind. } \\
\text { Homogeneity }\end{array}$ & & & $\begin{array}{c}0.054^{* *} \\
(0.039)\end{array}$ & & & & & \\
\hline \multicolumn{9}{|l|}{ Firm Characteristics } \\
\hline Pre-turnover Policy & $\begin{array}{c}0.259^{* * *} \\
(0.000)\end{array}$ & $\begin{array}{c}0.302 * * * \\
(0.000)\end{array}$ & $\begin{array}{c}0.556^{* * *} \\
(0.000)\end{array}$ & $\begin{array}{c}0.543 * * * \\
(0.000)\end{array}$ & $\begin{array}{c}0.197 * * * \\
(0.000)\end{array}$ & $\begin{array}{c}0.190^{* * *} \\
(0.000)\end{array}$ & $\begin{array}{c}0.202^{* * *} \\
(0.000)\end{array}$ & $\begin{array}{c}0.198^{* * *} \\
(0.000)\end{array}$ \\
\hline $\ln$ (Total Sales) & $\begin{array}{c}0.021 * * * \\
(0.000)\end{array}$ & $\begin{array}{c}-0.002 * * \\
(0.024)\end{array}$ & $\begin{array}{c}-0.002 * * \\
(0.043)\end{array}$ & $\begin{array}{l}0.001 * \\
(0.070)\end{array}$ & $\begin{array}{c}-0.019 * * * \\
(0.000)\end{array}$ & $\begin{array}{c}-0.031 * * * \\
(0.000)\end{array}$ & $\begin{array}{c}-0.019 * * * \\
(0.000)\end{array}$ & $\begin{array}{c}-0.019^{* * *} \\
(0.000)\end{array}$ \\
\hline Firm Age & $\begin{array}{l}-0.006 \\
(0.397)\end{array}$ & $\begin{array}{c}0.001 \\
(0.769)\end{array}$ & $\begin{array}{c}-0.003 * * \\
(0.011)\end{array}$ & $\begin{array}{c}0.001 \\
(0.347)\end{array}$ & & $\begin{array}{c}-0.062 * * * \\
(0.000)\end{array}$ & & \\
\hline $\begin{array}{l}\text { Operating Return on } \\
\text { Assets }\end{array}$ & $\begin{array}{c}-0.576^{* * * *} \\
(0.000)\end{array}$ & & & & $\begin{array}{l}-0.294 * * * \\
(0.000)\end{array}$ & $\begin{array}{c}-0.620 * * * \\
(0.000)\end{array}$ & $\begin{array}{c}-0.239 * * * \\
(0.000)\end{array}$ & $\begin{array}{c}-0.219^{* * *} \\
(0.000)\end{array}$ \\
\hline Surplus Cash & & $\begin{array}{c}0.020^{* *} \\
(0.019)\end{array}$ & $\begin{array}{c}0.120^{* * *} \\
(0.000)\end{array}$ & $\begin{array}{l}-0.011 \\
(0.253)\end{array}$ & & & & \\
\hline Tobin's Q & $\begin{array}{c}-0.021 * * * \\
(0.000)\end{array}$ & $\begin{array}{c}0.003 * * * \\
(0.002)\end{array}$ & $\begin{array}{l}-0.000 \\
(0.702)\end{array}$ & $\begin{array}{c}0.001 * * * \\
(0.008)\end{array}$ & $\begin{array}{c}0.009 * * * \\
(0.003)\end{array}$ & $\begin{array}{c}0.057 * * * \\
(0.000)\end{array}$ & $\begin{array}{l}0.006^{* *} \\
(0.032)\end{array}$ & $\begin{array}{l}0.005^{*} \\
(0.061)\end{array}$ \\
\hline R\&D/Total Assets & $\begin{array}{c}-0.346^{* * *} \\
(0.000)\end{array}$ & $\begin{array}{l}-0.039^{*} \\
(0.085)\end{array}$ & & $\begin{array}{c}0.004 \\
(0.768)\end{array}$ & $\begin{array}{c}0.499 * * * \\
(0.000)\end{array}$ & $\begin{array}{c}1.056^{* * *} \\
(0.000)\end{array}$ & $\begin{array}{c}0.435 * * * \\
(0.000)\end{array}$ & $\begin{array}{c}0.407 * * * \\
(0.000)\end{array}$ \\
\hline Adv./Total Assets & & $\begin{array}{c}0.016 \\
(0.638)\end{array}$ & $\begin{array}{l}-0.031 \\
(0.424)\end{array}$ & & $\begin{array}{c}0.146 \\
(0.197)\end{array}$ & $\begin{array}{l}-0.126 \\
(0.734)\end{array}$ & $\begin{array}{c}0.171 \\
(0.114)\end{array}$ & $\begin{array}{l}0.177^{*} \\
(0.095)\end{array}$ \\
\hline CAPEXP & & & $\begin{array}{l}-0.005 \\
(0.773)\end{array}$ & $\begin{array}{l}0.017 * \\
(0.084)\end{array}$ & $\begin{array}{c}0.296^{* * * *} \\
(0.000)\end{array}$ & $\begin{array}{c}0.558^{* * * *} \\
(0.009)\end{array}$ & $\begin{array}{c}0.251^{* * *} \\
(0.000)\end{array}$ & $\begin{array}{c}0.233^{* * *} \\
(0.000)\end{array}$ \\
\hline Leverage & & $\begin{array}{l}-0.012 \\
(0.112)\end{array}$ & $\begin{array}{l}0.006 \\
(0.296)\end{array}$ & $\begin{array}{l}-0.006^{*} \\
(0.061)\end{array}$ & $\begin{array}{c}0.072 * * * \\
(0.001)\end{array}$ & $\begin{array}{c}0.053 \\
(0.480)\end{array}$ & $\begin{array}{c}0.077^{* * *} \\
(0.000)\end{array}$ & $\begin{array}{c}0.077 * * * \\
(0.000)\end{array}$ \\
\hline Industry Homogeneity & & & $\begin{array}{c}-0.163 * * \\
(0.047)\end{array}$ & & & & & \\
\hline Capital Intensity & $\begin{array}{c}0.119^{* * *} \\
(0.000)\end{array}$ & & & & & & & \\
\hline Depr./Total Assets & $\begin{array}{l}-0.103 \\
(0.573)\end{array}$ & & & & & & & \\
\hline $\begin{array}{l}\text { Pay Director Equity- } \\
\text { based compensation }\end{array}$ & $\begin{array}{c}0.011 \\
(0.110)\end{array}$ & $\begin{array}{l}-0.001 \\
(0.784)\end{array}$ & $\begin{array}{c}0.002 \\
(0.155)\end{array}$ & $\begin{array}{c}0.002 \\
(0.109)\end{array}$ & $\begin{array}{c}0.009 \\
(0.176)\end{array}$ & $\begin{array}{c}0.004 \\
(0.876)\end{array}$ & $\begin{array}{c}0.008 \\
(0.197)\end{array}$ & $\begin{array}{c}0.008 \\
(0.176)\end{array}$ \\
\hline
\end{tabular}


Table B.1.10

\begin{tabular}{|c|c|c|c|c|c|c|c|c|}
\hline \multicolumn{9}{|c|}{ Firm Characteristics (Continued) } \\
\hline $\begin{array}{l}\text { Activist Institutional } \\
\text { Holding (\%) }\end{array}$ & $\begin{array}{l}-0.273 \\
(0.296)\end{array}$ & $\begin{array}{l}-0.060 \\
(0.342)\end{array}$ & $\begin{array}{c}0.063 \\
(0.155)\end{array}$ & $\begin{array}{l}-0.012 \\
(0.748)\end{array}$ & $\begin{array}{l}-0.136 \\
(0.509)\end{array}$ & $\begin{array}{l}1.521^{* *} \\
(0.029)\end{array}$ & $\begin{array}{l}-0.290 \\
(0.140)\end{array}$ & $\begin{array}{l}-0.301 \\
(0.117)\end{array}$ \\
\hline $\begin{array}{l}\text { CEO Cash } \\
\text { Compensation }\end{array}$ & $\begin{array}{c}0.016^{* *} \\
(0.028)\end{array}$ & $\begin{array}{l}-0.003 \\
(0.151)\end{array}$ & $\begin{array}{c}0.007 * * * \\
(0.001)\end{array}$ & $\begin{array}{l}0.002 * * \\
(0.035)\end{array}$ & $\begin{array}{c}-0.014 * * \\
(0.033)\end{array}$ & $\begin{array}{c}-0.100 * * * \\
(0.000)\end{array}$ & $\begin{array}{l}-0.009 \\
(0.139)\end{array}$ & $\begin{array}{l}-0.007 \\
(0.211)\end{array}$ \\
\hline $\begin{array}{l}\text { CEO Compensation } \\
\text { Delta }\end{array}$ & $\begin{array}{l}-0.006 \\
(0.136)\end{array}$ & $\begin{array}{l}-0.001 \\
(0.368)\end{array}$ & $\begin{array}{l}-0.000 \\
(0.743)\end{array}$ & $\begin{array}{c}0.001 \\
(0.219)\end{array}$ & $\begin{array}{c}0.002 \\
(0.555)\end{array}$ & $\begin{array}{c}0.022 \\
(0.184)\end{array}$ & $\begin{array}{c}0.000 \\
(0.984)\end{array}$ & $\begin{array}{l}-0.000 \\
(0.908)\end{array}$ \\
\hline $\begin{array}{l}\text { CEO Compensation } \\
\text { Vega }\end{array}$ & $\begin{array}{c}-0.019 * * \\
(0.047)\end{array}$ & $\begin{array}{l}-0.001 \\
(0.771)\end{array}$ & $\begin{array}{c}0.003 \\
(0.203)\end{array}$ & $\begin{array}{l}-0.002 \\
(0.260)\end{array}$ & $\begin{array}{l}-0.011 \\
(0.173)\end{array}$ & $\begin{array}{c}-0.075^{* *} \\
(0.018)\end{array}$ & $\begin{array}{l}-0.009 \\
(0.166)\end{array}$ & $\begin{array}{l}-0.008 \\
(0.208)\end{array}$ \\
\hline \multicolumn{9}{|l|}{ CEO Characteristics } \\
\hline Ln(CEO Tenure+1) & $\begin{array}{l}0.005 \\
(0.397)\end{array}$ & $\begin{array}{c}-0.004 * * \\
(0.014)\end{array}$ & $\begin{array}{l}-0.000 \\
(0.767)\end{array}$ & $\begin{array}{l}-0.001 \\
(0.137)\end{array}$ & $\begin{array}{c}0.000 \\
(0.920)\end{array}$ & $\begin{array}{l}-0.002 \\
(0.875)\end{array}$ & $\begin{array}{l}-0.002 \\
(0.672)\end{array}$ & $\begin{array}{l}-0.002 \\
(0.576)\end{array}$ \\
\hline CEO Age & $\begin{array}{c}-0.076^{* *} \\
(0.021)\end{array}$ & $\begin{array}{l}-0.011 \\
(0.233)\end{array}$ & $\begin{array}{l}-0.012 \\
(0.107)\end{array}$ & $\begin{array}{l}-0.004 \\
(0.416)\end{array}$ & $\begin{array}{c}-0.062 * * \\
(0.016)\end{array}$ & $\begin{array}{c}0.070 \\
(0.431)\end{array}$ & $\begin{array}{c}-0.061 * * * \\
(0.009)\end{array}$ & $\begin{array}{c}-0.061 * * * \\
(0.007)\end{array}$ \\
\hline MBA $(0 / 1)$ & $\begin{array}{l}0.015^{*} \\
(0.059)\end{array}$ & $\begin{array}{l}-0.002 \\
(0.323)\end{array}$ & $\begin{array}{c}0.002 \\
(0.211)\end{array}$ & $\begin{array}{l}-0.001 \\
(0.381)\end{array}$ & $\begin{array}{l}-0.010^{*} \\
(0.078)\end{array}$ & $\begin{array}{c}0.004 \\
(0.855)\end{array}$ & $\begin{array}{l}-0.010^{*} \\
(0.063)\end{array}$ & $\begin{array}{l}-0.010^{*} \\
(0.051)\end{array}$ \\
\hline Founder $(0 / 1)$ & $\begin{array}{c}0.013 \\
(0.351)\end{array}$ & $\begin{array}{l}-0.005 \\
(0.184)\end{array}$ & $\begin{array}{l}-0.005 \\
(0.168)\end{array}$ & $\begin{array}{l}-0.002 \\
(0.362)\end{array}$ & $\begin{array}{c}0.024 * * \\
(0.028)\end{array}$ & $\begin{array}{c}0.056 \\
(0.116)\end{array}$ & $\begin{array}{c}0.022 * * \\
(0.028)\end{array}$ & $\begin{array}{l}0.021 * * \\
(0.027)\end{array}$ \\
\hline \# Functional Areas & $\begin{array}{l}-0.002 \\
(0.666)\end{array}$ & $\begin{array}{l}-0.001 \\
(0.558)\end{array}$ & $\begin{array}{c}0.001 \\
(0.382)\end{array}$ & $\begin{array}{l}-0.001 \\
(0.325)\end{array}$ & $\begin{array}{c}0.002 \\
(0.399)\end{array}$ & $\begin{array}{c}0.006 \\
(0.550)\end{array}$ & $\begin{array}{c}0.002 \\
(0.547)\end{array}$ & $\begin{array}{c}0.001 \\
(0.732)\end{array}$ \\
\hline $\begin{array}{l}\text { Has Finance } \\
\text { Background }(0 / 1)\end{array}$ & $\begin{array}{c}0.011 \\
(0.206)\end{array}$ & $\begin{array}{l}-0.005^{*} \\
(0.096)\end{array}$ & $\begin{array}{c}-0.006^{* * *} \\
(0.001)\end{array}$ & $\begin{array}{l}-0.001 \\
(0.447)\end{array}$ & $\begin{array}{c}0.001 \\
(0.855)\end{array}$ & $\begin{array}{c}0.001 \\
(0.963)\end{array}$ & $\begin{array}{c}0.001 \\
(0.813)\end{array}$ & $\begin{array}{c}0.001 \\
(0.843)\end{array}$ \\
\hline Constant & $\begin{array}{l}0.298^{* *} \\
(0.038)\end{array}$ & $\begin{array}{c}0.126^{* * *} \\
(0.001)\end{array}$ & $\begin{array}{c}0.106 * * * \\
(0.002)\end{array}$ & $\begin{array}{c}0.011 \\
(0.568)\end{array}$ & $\begin{array}{c}0.613 * * * \\
(0.000)\end{array}$ & $\begin{array}{l}0.662 * \\
(0.064)\end{array}$ & $\begin{array}{c}0.611^{* * *} \\
(0.000)\end{array}$ & $\begin{array}{c}0.606^{* * *} \\
(0.000)\end{array}$ \\
\hline Year Dummies & Yes & Yes & Yes & Yes & Yes & Yes & Yes & Yes \\
\hline Industry Dummies & Yes & Yes & Yes & Yes & Yes & Yes & Yes & Yes \\
\hline Observations & 4826 & 5029 & 4914 & 5074 & 4693 & 4693 & 4693 & 4693 \\
\hline R-squared & 0.573 & 0.513 & 0.745 & 0.632 & 0.633 & 0.452 & 0.652 & 0.650 \\
\hline Hansen's J-test (p-value) & 0.167 & 0.856 & 0.379 & 0.628 & 0.131 & 0.887 & 0.139 & 0.166 \\
\hline $\begin{array}{l}\text { First Stage } F \text {-stat for } \\
\text { \#Employers }\end{array}$ & 39.44 & 55.58 & 40.67 & 47.89 & 62.54 & 76.47 & 61.66 & 61.75 \\
\hline $\begin{array}{l}\text { First Stage F-stat for \#En } \\
\text { Homogeneity }\end{array}$ & nployers * & Industry & 27.08 & & & & & \\
\hline
\end{tabular}




\section{Table B.2.1: OLS Results}

This table presents OLS results for firm policies and risk. The dependent variables are listed at the top of each column. Refer to Table 1 and Appendix A for variable definitions. Pre-turnover firm policies are the respective firm policies in the year before the CEO turnover year. The predicted signs for the CEO employment history proxies are presented in parenthesis at the top of each column. I report $p$-values based on robust standard errors clustered at the firm level in parenthesis. ${ }^{* * *}, * *$, and $*$ indicate significance at the 1,5 , and $10 \%$ levels, respectively.

\begin{tabular}{|c|c|c|c|c|c|c|c|c|}
\hline & Leverage & CAPEXP & $R \& D$ & Adv. & $\begin{array}{c}\text { Total Risk } \\
\text { (Ann. Daily } \\
\text { Stock } \\
\text { Return Std.) }\end{array}$ & $\begin{array}{c}\text { Market } \\
\text { Risk } \\
\text { (CAPM) }\end{array}$ & $\begin{array}{c}\text { Firm- } \\
\text { specific } \\
\text { Risk } \\
\text { (CAPM) }\end{array}$ & $\begin{array}{c}\text { Firm- } \\
\text { specific } \\
\text { Risk } \\
\text { (4- Factor) }\end{array}$ \\
\hline & $(+)$ & $(-)$ & $(+)$ & $(+)$ & $(+)$ & $(+)$ & $(+)$ & $(+)$ \\
\hline \#Employers & $\begin{array}{l}0.005^{*} \\
(0.055)\end{array}$ & $\begin{array}{l}-0.000 \\
(0.581)\end{array}$ & $\begin{array}{l}-0.002 * \\
(0.050)\end{array}$ & $\begin{array}{l}0.001^{*} \\
(0.059)\end{array}$ & $\begin{array}{l}0.004^{* *} \\
(0.035)\end{array}$ & $\begin{array}{c}0.004 \\
(0.528)\end{array}$ & $\begin{array}{l}0.004^{* *} \\
(0.027)\end{array}$ & $\begin{array}{l}0.004^{* *} \\
(0.019)\end{array}$ \\
\hline $\begin{array}{l}\text { \#Employers * Ind. } \\
\text { Homogeneity }\end{array}$ & & & $\begin{array}{l}0.007^{*} \\
(0.084)\end{array}$ & & & & & \\
\hline \multicolumn{9}{|l|}{ Firm Characteristics } \\
\hline Pre-turnover Policy & $\begin{array}{c}0.314 * * * \\
(0.000)\end{array}$ & $\begin{array}{c}0.311^{* * *} \\
(0.000)\end{array}$ & $\begin{array}{c}0.585^{* * *} \\
(0.000)\end{array}$ & $\begin{array}{c}0.591 * * * \\
(0.000)\end{array}$ & $\begin{array}{c}0.193^{* * *} \\
(0.000)\end{array}$ & $\begin{array}{c}0.189^{* * *} \\
(0.000)\end{array}$ & $\begin{array}{c}0.202^{* * *} \\
(0.000)\end{array}$ & $\begin{array}{c}0.199 * * * \\
(0.000)\end{array}$ \\
\hline $\ln$ (Total Sales) & $\begin{array}{c}0.025 * * * \\
(0.000)\end{array}$ & $\begin{array}{l}-0.001 \\
(0.165)\end{array}$ & $\begin{array}{c}-0.002 * * \\
(0.018)\end{array}$ & $\begin{array}{c}0.000 \\
(0.242)\end{array}$ & $\begin{array}{c}-0.019 * * * \\
(0.000)\end{array}$ & $\begin{array}{c}-0.027 * * * \\
(0.001)\end{array}$ & $\begin{array}{c}-0.020 * * * \\
(0.000)\end{array}$ & $\begin{array}{c}-0.019 * * * \\
(0.000)\end{array}$ \\
\hline Firm Age & $\begin{array}{l}-0.009 \\
(0.193)\end{array}$ & $\begin{array}{c}0.002 \\
(0.299)\end{array}$ & $\begin{array}{c}-0.004 * * * \\
(0.002)\end{array}$ & $\begin{array}{c}0.000 \\
(0.758)\end{array}$ & $\begin{array}{c}-0.020 * * * \\
(0.000)\end{array}$ & $\begin{array}{c}-0.058^{* * *} \\
(0.001)\end{array}$ & $\begin{array}{c}-0.017 * * * \\
(0.000)\end{array}$ & $\begin{array}{c}-0.017 * * * \\
(0.000)\end{array}$ \\
\hline $\begin{array}{l}\text { Operating Return on } \\
\text { Assets }\end{array}$ & $\begin{array}{c}-0.547 * * * \\
(0.000)\end{array}$ & & & & $\begin{array}{c}-0.290 * * * \\
(0.000)\end{array}$ & $\begin{array}{c}-0.627 * * * \\
(0.000)\end{array}$ & $\begin{array}{c}-0.235^{* * *} \\
(0.000)\end{array}$ & $\begin{array}{c}-0.215^{* * *} \\
(0.000)\end{array}$ \\
\hline Surplus Cash & & $\begin{array}{l}0.022 * * \\
(0.012)\end{array}$ & $\begin{array}{c}0.130^{* * *} \\
(0.000)\end{array}$ & $\begin{array}{l}-0.008 \\
(0.397)\end{array}$ & & & & \\
\hline Tobin's Q & $\begin{array}{c}-0.021 * * * \\
(0.000)\end{array}$ & $\begin{array}{c}0.003 * * * \\
(0.001)\end{array}$ & $\begin{array}{l}-0.000 \\
(0.900)\end{array}$ & $\begin{array}{c}0.001 * * \\
(0.016)\end{array}$ & $\begin{array}{c}0.008^{* * *} \\
(0.008)\end{array}$ & $\begin{array}{c}0.057 * * * \\
(0.000)\end{array}$ & $\begin{array}{l}0.005^{*} \\
(0.080)\end{array}$ & $\begin{array}{c}0.004 \\
(0.138)\end{array}$ \\
\hline R\&D/Total Assets & $\begin{array}{c}-0.372 * * * \\
(0.000)\end{array}$ & $\begin{array}{l}-0.041^{*} \\
(0.067)\end{array}$ & & $\begin{array}{l}-0.021 \\
(0.166)\end{array}$ & $\begin{array}{c}0.476^{* * * *} \\
(0.000)\end{array}$ & $\begin{array}{c}1.052 * * * \\
(0.000)\end{array}$ & $\begin{array}{c}0.414 * * * \\
(0.000)\end{array}$ & $\begin{array}{c}0.387 * * * \\
(0.000)\end{array}$ \\
\hline Adv./Total Assets & & $\begin{array}{c}0.006 \\
(0.864)\end{array}$ & $\begin{array}{l}-0.055^{*} \\
(0.062)\end{array}$ & & $\begin{array}{c}0.157 \\
(0.163)\end{array}$ & $\begin{array}{l}-0.156 \\
(0.670)\end{array}$ & $\begin{array}{l}0.183^{*} \\
(0.087)\end{array}$ & $\begin{array}{l}0.189^{*} \\
(0.071)\end{array}$ \\
\hline CAPEXP & & & $\begin{array}{l}-0.008 \\
(0.585)\end{array}$ & $\begin{array}{r}0.021^{* *} \\
(0.029)\end{array}$ & $\begin{array}{c}0.285^{* * *} \\
(0.000)\end{array}$ & $\begin{array}{c}0.580^{* * *} \\
(0.007)\end{array}$ & $\begin{array}{c}0.239 * * * \\
(0.000)\end{array}$ & $\begin{array}{c}0.220^{* * *} \\
(0.000)\end{array}$ \\
\hline Leverage & & $\begin{array}{l}-0.015^{*} \\
(0.055)\end{array}$ & $\begin{array}{c}0.007 \\
(0.103)\end{array}$ & $\begin{array}{c}-0.007 * * \\
(0.043)\end{array}$ & $\begin{array}{c}0.072 * * * \\
(0.001)\end{array}$ & $\begin{array}{c}0.038 \\
(0.612)\end{array}$ & $\begin{array}{l}0.079 * * * \\
(0.000)\end{array}$ & $\begin{array}{c}0.079 * * * \\
(0.000)\end{array}$ \\
\hline Industry Homogeneity & & & $\begin{array}{c}-0.040^{* * *} \\
(0.002)\end{array}$ & & & & & \\
\hline Capital Intensity & $\begin{array}{l}0.083 * * * \\
(0.003)\end{array}$ & & & & & & & \\
\hline Depr./Total Assets & $\begin{array}{c}0.080 \\
(0.662)\end{array}$ & & & & & & & \\
\hline $\begin{array}{l}\text { Pay Director Equity- } \\
\text { based compensation }\end{array}$ & $\begin{array}{c}0.011 \\
(0.122)\end{array}$ & $\begin{array}{l}-0.001 \\
(0.597)\end{array}$ & $\begin{array}{c}0.001 \\
(0.331)\end{array}$ & $\begin{array}{l}0.002^{*} \\
(0.054)\end{array}$ & $\begin{array}{c}0.009 \\
(0.197)\end{array}$ & $\begin{array}{c}0.002 \\
(0.945)\end{array}$ & $\begin{array}{c}0.008 \\
(0.202)\end{array}$ & $\begin{array}{c}0.008 \\
(0.177)\end{array}$ \\
\hline $\begin{array}{l}\text { Activist Institutional } \\
\text { Holding (\%) }\end{array}$ & $\begin{array}{l}-0.200 \\
(0.439)\end{array}$ & $\begin{array}{l}-0.059 \\
(0.340)\end{array}$ & $\begin{array}{c}0.053 \\
(0.269)\end{array}$ & $\begin{array}{l}-0.019 \\
(0.657)\end{array}$ & $\begin{array}{l}-0.130 \\
(0.531)\end{array}$ & $\begin{array}{l}1.501^{* *} \\
(0.033)\end{array}$ & $\begin{array}{l}-0.281 \\
(0.155)\end{array}$ & $\begin{array}{l}-0.291 \\
(0.132)\end{array}$ \\
\hline $\begin{array}{l}\text { CEO Cash } \\
\text { Compensation }\end{array}$ & $\begin{array}{c}0.023 * * * \\
(0.002)\end{array}$ & $\begin{array}{l}-0.003 \\
(0.130)\end{array}$ & $\begin{array}{c}0.006^{* * *} \\
(0.003)\end{array}$ & $\begin{array}{c}0.004 * * * \\
(0.004)\end{array}$ & $\begin{array}{c}-0.014 * * \\
(0.045)\end{array}$ & $\begin{array}{c}-0.101 * * * \\
(0.000)\end{array}$ & $\begin{array}{l}-0.008 \\
(0.181)\end{array}$ & $\begin{array}{l}-0.006 \\
(0.272)\end{array}$ \\
\hline
\end{tabular}


Table B.2.1Continued

\begin{tabular}{|c|c|c|c|c|c|c|c|c|}
\hline \multicolumn{9}{|c|}{ Firm Characteristics (Continued) } \\
\hline $\begin{array}{l}\text { CEO Compensation } \\
\text { Delta }\end{array}$ & $\begin{array}{l}-0.007 \\
(0.103)\end{array}$ & $\begin{array}{l}-0.001 \\
(0.342)\end{array}$ & $\begin{array}{l}-0.001 \\
(0.153)\end{array}$ & $\begin{array}{c}0.000 \\
(0.993)\end{array}$ & $\begin{array}{c}0.002 \\
(0.578)\end{array}$ & $\begin{array}{c}0.022 \\
(0.191)\end{array}$ & $\begin{array}{l}-0.000 \\
(0.994)\end{array}$ & $\begin{array}{l}-0.000 \\
(0.885)\end{array}$ \\
\hline $\begin{array}{l}\text { CEO Compensation } \\
\text { Vega }\end{array}$ & $\begin{array}{c}-0.027^{* * *} \\
(0.007)\end{array}$ & $\begin{array}{l}-0.002 \\
(0.460)\end{array}$ & $\begin{array}{l}0.005^{* *} \\
(0.015)\end{array}$ & $\begin{array}{c}0.000 \\
(0.941)\end{array}$ & $\begin{array}{l}-0.010 \\
(0.172)\end{array}$ & $\begin{array}{c}-0.078 * * \\
(0.014)\end{array}$ & $\begin{array}{l}-0.009 \\
(0.189)\end{array}$ & $\begin{array}{l}-0.007 \\
(0.247)\end{array}$ \\
\hline Herfindhal Index & $\begin{array}{c}0.354 * * * \\
(0.005)\end{array}$ & $\begin{array}{l}-0.037 \\
(0.322)\end{array}$ & $\begin{array}{l}-0.002 \\
(0.771)\end{array}$ & $\begin{array}{l}0.027^{* *} \\
(0.010)\end{array}$ & $\begin{array}{c}0.355^{* * *} \\
(0.001)\end{array}$ & $\begin{array}{c}0.411 \\
(0.349)\end{array}$ & $\begin{array}{c}0.306 * * * \\
(0.002)\end{array}$ & $\begin{array}{c}0.288^{* * *} \\
(0.003)\end{array}$ \\
\hline \multicolumn{9}{|l|}{ CEO Characteristics } \\
\hline Ln(CEO Tenure+1) & $\begin{array}{c}0.003 \\
(0.569)\end{array}$ & $\begin{array}{l}-0.003 * \\
(0.077)\end{array}$ & $\begin{array}{l}0.000 \\
(0.867)\end{array}$ & $\begin{array}{l}-0.001^{*} \\
(0.086)\end{array}$ & $\begin{array}{l}-0.000 \\
(0.991)\end{array}$ & $\begin{array}{l}0.001 \\
(0.937)\end{array}$ & $\begin{array}{l}-0.003 \\
(0.512)\end{array}$ & $\begin{array}{l}-0.004 \\
(0.399)\end{array}$ \\
\hline CEO Age & $\begin{array}{l}-0.058^{*} \\
(0.053)\end{array}$ & $\begin{array}{c}-0.021^{* *} \\
(0.015)\end{array}$ & $\begin{array}{c}-0.018^{* *} \\
(0.012)\end{array}$ & $\begin{array}{l}-0.003 \\
(0.544)\end{array}$ & $\begin{array}{l}-0.049^{*} \\
(0.055)\end{array}$ & $\begin{array}{c}0.038 \\
(0.659)\end{array}$ & $\begin{array}{c}-0.047^{* *} \\
(0.045)\end{array}$ & $\begin{array}{c}-0.046^{* *} \\
(0.040)\end{array}$ \\
\hline $\operatorname{MBA}(0 / 1)$ & $\begin{array}{l}0.015^{* *} \\
(0.047)\end{array}$ & $\begin{array}{l}-0.003 * \\
(0.093)\end{array}$ & $\begin{array}{c}0.002 \\
(0.329)\end{array}$ & $\begin{array}{c}0.000 \\
(0.807)\end{array}$ & $\begin{array}{l}-0.009 \\
(0.103)\end{array}$ & $\begin{array}{l}-0.000 \\
(0.989)\end{array}$ & $\begin{array}{l}-0.008^{*} \\
(0.096)\end{array}$ & $\begin{array}{c}-0.008^{*} \\
(0.084)\end{array}$ \\
\hline Founder $(0 / 1)$ & $\begin{array}{c}0.007 \\
(0.563)\end{array}$ & $\begin{array}{l}-0.001 \\
(0.808)\end{array}$ & $\begin{array}{l}-0.005 \\
(0.114)\end{array}$ & $\begin{array}{l}-0.001 \\
(0.665)\end{array}$ & $\begin{array}{c}0.021 * * \\
(0.042)\end{array}$ & $\begin{array}{l}0.070^{* *} \\
(0.030)\end{array}$ & $\begin{array}{l}0.018^{*} \\
(0.062)\end{array}$ & $\begin{array}{l}0.016^{*} \\
(0.069)\end{array}$ \\
\hline \# Functional Areas & $\begin{array}{l}-0.001 \\
(0.812)\end{array}$ & $\begin{array}{l}-0.001 \\
(0.222)\end{array}$ & $\begin{array}{c}0.001 \\
(0.278)\end{array}$ & $\begin{array}{l}-0.001 \\
(0.127)\end{array}$ & $\begin{array}{c}0.003 \\
(0.307)\end{array}$ & $\begin{array}{c}0.004 \\
(0.687)\end{array}$ & $\begin{array}{c}0.002 \\
(0.383)\end{array}$ & $\begin{array}{c}0.002 \\
(0.517)\end{array}$ \\
\hline $\begin{array}{l}\text { Has Finance } \\
\text { Background }(0 / 1)\end{array}$ & $\begin{array}{c}0.011 \\
(0.232)\end{array}$ & $\begin{array}{l}-0.005^{*} \\
(0.077)\end{array}$ & $\begin{array}{c}-0.005^{* * *} \\
(0.001)\end{array}$ & $\begin{array}{l}-0.001 \\
(0.542)\end{array}$ & $\begin{array}{c}0.001 \\
(0.858)\end{array}$ & $\begin{array}{l}-0.001 \\
(0.972)\end{array}$ & $\begin{array}{c}0.002 \\
(0.786)\end{array}$ & $\begin{array}{c}0.001 \\
(0.808)\end{array}$ \\
\hline Constant & $\begin{array}{c}0.140 \\
(0.305)\end{array}$ & $\begin{array}{c}0.159 * * * \\
(0.000)\end{array}$ & $\begin{array}{c}0.107^{* * *} \\
(0.000)\end{array}$ & $\begin{array}{c}0.030 \\
(0.182)\end{array}$ & $\begin{array}{c}0.574 * * * \\
(0.000)\end{array}$ & $\begin{array}{l}0.668^{*} \\
(0.069)\end{array}$ & $\begin{array}{c}0.582 * * * \\
(0.000)\end{array}$ & $\begin{array}{c}0.581^{* * *} \\
(0.000)\end{array}$ \\
\hline Year Dummies & Yes & Yes & Yes & Yes & Yes & Yes & Yes & Yes \\
\hline Industry Dummies & Yes & Yes & Yes & Yes & Yes & Yes & Yes & Yes \\
\hline Observations & 4826 & 5029 & 4914 & 5074 & 4693 & 4693 & 4693 & 4693 \\
\hline $\mathrm{R}$-squared & 0.585 & 0.525 & 0.752 & 0.597 & 0.636 & 0.453 & 0.656 & 0.654 \\
\hline
\end{tabular}




\section{Table B.2.2: Results based on Between Effects}

This table presents results based on the between effect estimation. The dependent variables are listed at the top of each column. Refer to Table 1 and Appendix A for variable definitions. Pre-turnover firm policies are the respective firm policies in the year before the CEO turnover year. The predicted signs for the CEO employment history proxies are presented in parenthesis at the top of each column. I report $p$-values based on robust standard errors clustered at the firm level in parenthesis.***, $* *$, and $*$ indicate significance at the 1,5 , and $10 \%$ levels, respectively.

\begin{tabular}{|c|c|c|c|c|c|c|c|c|}
\hline & Leverage & CAPEXP & $\mathrm{R} \& \mathrm{D}$ & Adv. & $\begin{array}{c}\text { Total Risk } \\
\text { (Ann. Daily } \\
\text { Stock } \\
\text { Return Std.) } \\
\end{array}$ & $\begin{array}{c}\text { Market } \\
\text { Risk } \\
\text { (CAPM) }\end{array}$ & $\begin{array}{c}\text { Firm- } \\
\text { specific } \\
\text { Risk } \\
\text { (CAPM) } \\
\end{array}$ & $\begin{array}{c}\text { Firm- } \\
\text { specific } \\
\text { Risk } \\
\text { (4- Factor) }\end{array}$ \\
\hline & $(+)$ & $(-)$ & $(+)$ & $(+)$ & $(+)$ & $(+)$ & $(+)$ & $(+)$ \\
\hline \#Employers & $\begin{array}{l}0.011^{* *} \\
(0.020)\end{array}$ & $\begin{array}{c}-0.003 * * \\
(0.030)\end{array}$ & $\begin{array}{l}-0.019^{*} \\
(0.060)\end{array}$ & $\begin{array}{l}0.001 * * \\
(0.039)\end{array}$ & $\begin{array}{c}0.004 \\
(0.169)\end{array}$ & $\begin{array}{l}-0.006 \\
(0.663)\end{array}$ & $\begin{array}{l}0.005^{* *} \\
(0.045)\end{array}$ & $\begin{array}{l}0.006^{* *} \\
(0.026)\end{array}$ \\
\hline $\begin{array}{l}\text { \#Employers * Ind. } \\
\text { Homogeneity }\end{array}$ & & & $\begin{array}{l}0.084^{*} \\
(0.098)\end{array}$ & & & & & \\
\hline \multicolumn{9}{|l|}{ Firm Characteristics } \\
\hline Pre-turnover Policy & $\begin{array}{c}0.337 * * * \\
(0.000)\end{array}$ & $\begin{array}{c}0.366^{* * *} \\
(0.000)\end{array}$ & $\begin{array}{c}0.587^{* * *} \\
(0.000)\end{array}$ & $\begin{array}{c}0.612 * * * \\
(0.000)\end{array}$ & $\begin{array}{c}0.215^{* * *} \\
(0.000)\end{array}$ & $\begin{array}{c}0.249 * * * \\
(0.000)\end{array}$ & $\begin{array}{c}0.224 * * * \\
(0.000)\end{array}$ & $\begin{array}{c}0.222 * * * \\
(0.000)\end{array}$ \\
\hline $\ln$ (Total Sales) & $\begin{array}{c}0.020 * * * \\
(0.000)\end{array}$ & $\begin{array}{c}-0.003 * * * \\
(0.009)\end{array}$ & $\begin{array}{c}-0.002 * * \\
(0.036)\end{array}$ & $\begin{array}{l}0.001^{*} \\
(0.055)\end{array}$ & $\begin{array}{c}-0.021 * * * \\
(0.000)\end{array}$ & $\begin{array}{c}-0.050^{* * *} \\
(0.000)\end{array}$ & $\begin{array}{c}-0.020 * * * \\
(0.000)\end{array}$ & $\begin{array}{c}-0.019 * * * \\
(0.000)\end{array}$ \\
\hline Firm Age & $\begin{array}{l}-0.000 \\
(0.997)\end{array}$ & $\begin{array}{c}0.000 \\
(0.884)\end{array}$ & $\begin{array}{l}-0.002 \\
(0.196)\end{array}$ & $\begin{array}{c}0.000 \\
(0.985)\end{array}$ & $\begin{array}{c}-0.013 * * * \\
(0.004)\end{array}$ & $\begin{array}{c}-0.049 * * * \\
(0.007)\end{array}$ & $\begin{array}{c}-0.011 * * * \\
(0.009)\end{array}$ & $\begin{array}{c}-0.010^{* *} \\
(0.013)\end{array}$ \\
\hline $\begin{array}{l}\text { Operating Return on } \\
\text { Assets }\end{array}$ & $\begin{array}{c}-0.665^{* * *} \\
(0.000)\end{array}$ & & & & $\begin{array}{c}-0.457 * * * \\
(0.000)\end{array}$ & $\begin{array}{l}-0.290 \\
(0.195)\end{array}$ & $\begin{array}{c}-0.418 * * * \\
(0.000)\end{array}$ & $\begin{array}{c}-0.407 * * * \\
(0.000)\end{array}$ \\
\hline Surplus Cash & & $\begin{array}{c}0.018 \\
(0.359)\end{array}$ & $\begin{array}{c}0.090 * * * \\
(0.000)\end{array}$ & $\begin{array}{c}-0.030 * * * \\
(0.007)\end{array}$ & & & & \\
\hline Tobin's Q & $\begin{array}{c}-0.012 * * \\
(0.018)\end{array}$ & $\begin{array}{l}0.003 * * \\
(0.032)\end{array}$ & $\begin{array}{l}0.001 \\
(0.465)\end{array}$ & $\begin{array}{l}0.002 * * \\
(0.019)\end{array}$ & $\begin{array}{c}0.012 * * * \\
(0.001)\end{array}$ & $\begin{array}{c}0.020 \\
(0.167)\end{array}$ & $\begin{array}{c}0.010^{* * * *} \\
(0.001)\end{array}$ & $\begin{array}{l}0.010 * * * \\
(0.002)\end{array}$ \\
\hline R\&D/Total Assets & $\begin{array}{c}-0.431 * * * \\
(0.000)\end{array}$ & $\begin{array}{l}-0.056^{*} \\
(0.074)\end{array}$ & & $\begin{array}{l}-0.017 \\
(0.307)\end{array}$ & $\begin{array}{c}0.422 * * * \\
(0.000)\end{array}$ & $\begin{array}{c}1.092 * * * \\
(0.002)\end{array}$ & $\begin{array}{c}0.358 * * * \\
(0.000)\end{array}$ & $\begin{array}{l}0.338 * * * \\
(0.000)\end{array}$ \\
\hline Adv./Total Assets & & $\begin{array}{c}0.002 \\
(0.954)\end{array}$ & $\begin{array}{l}-0.056 \\
(0.221)\end{array}$ & & $\begin{array}{l}0.196^{*} \\
(0.073)\end{array}$ & $\begin{array}{l}-0.599 \\
(0.184)\end{array}$ & $\begin{array}{l}0.224 * * \\
(0.025)\end{array}$ & $\begin{array}{l}0.236^{* *} \\
(0.015)\end{array}$ \\
\hline CAPEXP & & & $\begin{array}{l}-0.009 \\
(0.746)\end{array}$ & $\begin{array}{l}0.035^{* *} \\
(0.044)\end{array}$ & $\begin{array}{c}0.365 * * * \\
(0.000)\end{array}$ & $\begin{array}{c}0.447 \\
(0.187)\end{array}$ & $\begin{array}{c}0.330^{* * *} \\
(0.000)\end{array}$ & $\begin{array}{c}0.315^{* * *} \\
(0.000)\end{array}$ \\
\hline Leverage & & $\begin{array}{l}-0.007 \\
(0.409)\end{array}$ & $\begin{array}{c}0.002 \\
(0.842)\end{array}$ & $\begin{array}{c}-0.014 * * * \\
(0.003)\end{array}$ & $\begin{array}{c}0.090^{* * *} \\
(0.000)\end{array}$ & $\begin{array}{c}0.267 * * * \\
(0.005)\end{array}$ & $\begin{array}{c}0.085^{* * *} \\
(0.000)\end{array}$ & $\begin{array}{c}0.083^{* * *} \\
(0.000)\end{array}$ \\
\hline Industry Homo & & & $\begin{array}{l}-0.276 \\
(0.108)\end{array}$ & & & & & \\
\hline Capital Intensity & $\begin{array}{c}0.097 * * * \\
(0.003)\end{array}$ & & & & & & & \\
\hline Depr./Total Assets & $\begin{array}{c}0.041 \\
(0.848)\end{array}$ & & & & & & & \\
\hline $\begin{array}{l}\text { Pay Director Equity- } \\
\text { based compensation }\end{array}$ & $\begin{array}{c}0.010 \\
(0.456)\end{array}$ & $\begin{array}{l}-0.002 \\
(0.552)\end{array}$ & $\begin{array}{l}0.005 \\
(0.119)\end{array}$ & $\begin{array}{l}0.004 * * \\
(0.043)\end{array}$ & $\begin{array}{l}0.019 * \\
(0.060)\end{array}$ & $\begin{array}{l}-0.012 \\
(0.771)\end{array}$ & $\begin{array}{r}0.020^{* *} \\
(0.031)\end{array}$ & $\begin{array}{l}0.020^{* *} \\
(0.027)\end{array}$ \\
\hline $\begin{array}{l}\text { Activist Institutional } \\
\text { Holding (\%) }\end{array}$ & $\begin{array}{c}0.180 \\
(0.656)\end{array}$ & $\begin{array}{c}0.017 \\
(0.882)\end{array}$ & $\begin{array}{l}-0.056 \\
(0.618)\end{array}$ & $\begin{array}{l}-0.085 \\
(0.182)\end{array}$ & $\begin{array}{c}0.256 \\
(0.411)\end{array}$ & $\begin{array}{c}1.895 \\
(0.140)\end{array}$ & $\begin{array}{c}0.083 \\
(0.769)\end{array}$ & $\begin{array}{c}0.014 \\
(0.961)\end{array}$ \\
\hline CEO Cash & 0.003 & -0.005 & $0.017^{* * *}$ & 0.005 & 0.009 & 0.005 & 0.010 & 0.011 \\
\hline Compensation & $(0.878)$ & $(0.381)$ & $(0.002)$ & $(0.120)$ & $(0.508)$ & $(0.929)$ & $(0.432)$ & $(0.398)$ \\
\hline
\end{tabular}


Table B.2.2 Continued

\begin{tabular}{lcccccccc}
\hline Firm Characteristics (Continued) & & & & & & & \\
CEO Compensation & -0.003 & -0.002 & 0.000 & 0.001 & 0.003 & $0.040^{*}$ & -0.000 & -0.000 \\
Delta & $(0.618)$ & $(0.279)$ & $(0.874)$ & $(0.353)$ & $(0.629)$ & $(0.068)$ & $(0.984)$ & $(0.922)$ \\
CEO Compensation & $-0.035^{* *}$ & 0.001 & 0.003 & -0.002 & -0.002 & -0.019 & -0.004 & -0.004 \\
Vega & $(0.026)$ & $(0.806)$ & $(0.530)$ & $(0.416)$ & $(0.853)$ & $(0.690)$ & $(0.691)$ & $(0.687)$ \\
Herfindhal Index & 0.863 & -0.056 & -0.092 & 0.060 & $1.301^{* * *}$ & 2.168 & $1.136^{* * *}$ & $1.061^{* * *}$ \\
& $(0.117)$ & $(0.715)$ & $(0.566)$ & $(0.469)$ & $(0.001)$ & $(0.183)$ & $(0.002)$ & $(0.002)$ \\
CEO Characteristics & & & & & & & & \\
Ln(CEO Tenure+1) & $-0.022^{* *}$ & $-0.011^{* * *}$ & $-0.004^{*}$ & $-0.002^{*}$ & -0.004 & $0.059^{*}$ & -0.006 & -0.005 \\
& $(0.031)$ & $(0.000)$ & $(0.074)$ & $(0.096)$ & $(0.606)$ & $(0.069)$ & $(0.440)$ & $(0.453)$ \\
CEO Age & $-0.079^{* *}$ & -0.003 & -0.009 & -0.005 & -0.025 & 0.088 & -0.031 & -0.032 \\
& $(0.010)$ & $(0.739)$ & $(0.250)$ & $(0.305)$ & $(0.272)$ & $(0.352)$ & $(0.137)$ & $(0.117)$ \\
MBA (0/1) & 0.009 & -0.001 & 0.001 & -0.000 & -0.004 & 0.024 & -0.005 & -0.005 \\
& $(0.200)$ & $(0.783)$ & $(0.506)$ & $(0.885)$ & $(0.445)$ & $(0.267)$ & $(0.337)$ & $(0.291)$ \\
Founder (0/1) & 0.005 & -0.002 & -0.005 & -0.003 & 0.012 & 0.007 & 0.013 & 0.013 \\
& $(0.693)$ & $(0.566)$ & $(0.210)$ & $(0.228)$ & $(0.225)$ & $(0.874)$ & $(0.156)$ & $(0.156)$ \\
\# Functional Areas & -0.003 & -0.001 & 0.001 & -0.001 & 0.003 & 0.002 & 0.002 & 0.002 \\
& $(0.410)$ & $(0.340)$ & $(0.218)$ & $(0.234)$ & $(0.321)$ & $(0.876)$ & $(0.375)$ & $(0.396)$ \\
Has Finance & 0.010 & -0.003 & $-0.006 * *$ & -0.000 & 0.003 & -0.008 & 0.003 & 0.003 \\
Background (0/1) & $(0.204)$ & $(0.279)$ & $(0.028)$ & $(0.936)$ & $(0.583)$ & $(0.741)$ & $(0.576)$ & $(0.639)$ \\
Constant & -0.449 & 0.061 & -0.045 & -0.013 & $0.543^{*}$ & 0.049 & $0.713^{*}$ & 0.681 \\
& $(0.471)$ & $(0.741)$ & $(0.795)$ & $(0.896)$ & $(0.054)$ & $(0.967)$ & $(0.096)$ & $(0.101)$ \\
Year Dummies & Yes & Yes & Yes & Yes & Yes & Yes & Yes & Yes \\
Industry Dummies & Yes & Yes & Yes & Yes & Yes & Yes & Yes & Yes \\
Observations & 4826 & 5029 & 4914 & 5074 & 4693 & 4693 & 4693 & 4693 \\
R-squared & 0.673 & 0.605 & 0.744 & 0.736 & 0.742 & 0.558 & 0.749 & 0.744 \\
\hline
\end{tabular}




\section{Table B.2.3: The Heckman Two-step Estimation}

This table presents results based on the Heckman Two-step Estimation to control for the CEO-firm selectivity. The dependent variables are listed at the top of each column. Mover equals one if the CEO has worked for more than three firms (sample median). Refer to Table 1 and Appendix A for variable definitions. Pre-turnover firm policies are the respective firm policies in the year before the CEO turnover year. The predicted signs for the CEO employment history proxies are presented in parenthesis at the top of each column. I report $p$-values based on robust standard errors clustered at the firm level in parenthesis. ${ }^{* *}, * *$, and $*$ indicate significance at the 1,5 , and $10 \%$ levels, respectively.

\begin{tabular}{|c|c|c|c|c|c|c|c|c|}
\hline & Leverage & CAPEXP & R\&D & Adv. & $\begin{array}{c}\text { Total Risk } \\
\text { (Ann. Daily } \\
\text { Stock } \\
\text { Return Std.) }\end{array}$ & $\begin{array}{c}\text { Market } \\
\text { Risk } \\
\text { (CAPM) }\end{array}$ & $\begin{array}{c}\text { Firm- } \\
\text { specific } \\
\text { Risk } \\
\text { (CAPM) }\end{array}$ & $\begin{array}{c}\text { Firm- } \\
\text { specific } \\
\text { Risk } \\
\text { (4- Factor) }\end{array}$ \\
\hline & $(+)$ & $(-)$ & $(+)$ & $(+)$ & $(+)$ & $(+)$ & $(+)$ & $(+)$ \\
\hline $\begin{array}{l}\text { Mover }(0 / 1) \\
(1: \text { \#Employers }>3)\end{array}$ & $\begin{array}{l}0.066^{* * *} \\
(0.000)\end{array}$ & $\begin{array}{l}-0.014 * * * \\
(0.000)\end{array}$ & $\begin{array}{l}* 0.001 \\
(0.137)\end{array}$ & $\begin{array}{l}0.004 * * * \\
(0.008)\end{array}$ & $\begin{array}{l}0.007 \\
(0.452)\end{array}$ & $\begin{array}{l}-0.100^{* * *} \\
(0.007)\end{array}$ & $\begin{array}{l}0.016^{*} \\
(0.068)\end{array}$ & $\begin{array}{l}0.019^{* *} \\
(0.027)\end{array}$ \\
\hline \multicolumn{9}{|l|}{ Firm Characteristics } \\
\hline Pre-turnover Policy & $\begin{array}{l}0.325^{* * *} \\
(0.000)\end{array}$ & $\begin{array}{l}0.327 * * * \\
(0.000)\end{array}$ & $\begin{array}{l}0.814 * * * \\
(0.000)\end{array}$ & $\begin{array}{l}0.570^{* * *} \\
(0.000)\end{array}$ & $\begin{array}{l}0.196^{* * *} \\
(0.000)\end{array}$ & $\begin{array}{l}0.197 * * * \\
(0.000)\end{array}$ & $\begin{array}{l}0.206^{* * *} \\
(0.000)\end{array}$ & $\begin{array}{l}0.204 * * * \\
(0.000)\end{array}$ \\
\hline $\ln$ (Total Sales) & $\begin{array}{l}0.022 * * * \\
(0.000)\end{array}$ & $\begin{array}{l}-0.002 * * * \\
(0.000)\end{array}$ & $\begin{array}{l}*-0.000 \\
(0.405)\end{array}$ & $\begin{array}{l}0.001 * * \\
(0.015)\end{array}$ & $\begin{array}{l}-0.019 * * * \\
(0.000)\end{array}$ & $\begin{array}{l}-0.032^{* * *} \\
(0.000)\end{array}$ & $\begin{array}{l}-0.020^{* * *} \\
(0.000)\end{array}$ & $\begin{array}{l}-0.019 * * * \\
(0.000)\end{array}$ \\
\hline Firm Age & $\begin{array}{l}-0.006^{*} \\
(0.057)\end{array}$ & $\begin{array}{l}0.001 \\
(0.545)\end{array}$ & $\begin{array}{l}0.000 \\
(0.152)\end{array}$ & $\begin{array}{l}0.001 \\
(0.110)\end{array}$ & $\begin{array}{l}-0.022 * * * \\
(0.000)\end{array}$ & $\begin{array}{l}-0.063^{* * *} \\
(0.000)\end{array}$ & $\begin{array}{l}-0.019 * * * \\
(0.000)\end{array}$ & $\begin{array}{l}-0.018 * * * \\
(0.000)\end{array}$ \\
\hline $\begin{array}{l}\text { Operating Return on } \\
\text { Assets }\end{array}$ & $\begin{array}{l}-0.580 * * * \\
(0.000)\end{array}$ & & & & $\begin{array}{l}-0.292 * * * \\
(0.000)\end{array}$ & $\begin{array}{l}-0.622 * * * \\
(0.000)\end{array}$ & $\begin{array}{l}-0.238 * * * \\
(0.000)\end{array}$ & $\begin{array}{l}-0.218^{* * *} \\
(0.000)\end{array}$ \\
\hline Surplus Cash & & $\begin{array}{l}0.018^{* *} \\
(0.018)\end{array}$ & $\begin{array}{l}0.006^{* *} \\
(0.020)\end{array}$ & $\begin{array}{l}-0.011 * * * \\
(0.006)\end{array}$ & & & & \\
\hline Tobin's Q & $\begin{array}{l}-0.020^{* * *} \\
(0.000)\end{array}$ & $\begin{array}{l}0.003 * * * \\
(0.000)\end{array}$ & $\begin{array}{l}-0.000 \\
(0.337)\end{array}$ & $\begin{array}{l}0.002 * * * \\
(0.000)\end{array}$ & $\begin{array}{l}0.008^{* * *} \\
(0.000)\end{array}$ & $\begin{array}{l}0.049 * * * \\
(0.000)\end{array}$ & $\begin{array}{l}0.005 * * * \\
(0.002)\end{array}$ & $\begin{array}{l}0.004 * * * \\
(0.007)\end{array}$ \\
\hline R\&D/Total Assets & $\begin{array}{l}-0.436^{* * *} \\
(0.000)\end{array}$ & $\begin{array}{l}-0.052 * * * \\
(0.000)\end{array}$ & & $\begin{array}{l}-0.013^{*} \\
(0.061)\end{array}$ & $\begin{array}{l}0.480 * * * \\
(0.000)\end{array}$ & $\begin{array}{l}1.322 * * * \\
(0.000)\end{array}$ & $\begin{array}{l}0.391 * * * \\
(0.000)\end{array}$ & $\begin{array}{l}0.359^{* * *} \\
(0.000)\end{array}$ \\
\hline Adv./Total Assets & & $\begin{array}{l}0.015 \\
(0.478)\end{array}$ & $\begin{array}{l}-0.013 * * \\
(0.045)\end{array}$ & & $\begin{array}{l}0.079 \\
(0.221)\end{array}$ & $\begin{array}{l}-0.610^{* *} \\
(0.013)\end{array}$ & $\begin{array}{l}0.128^{* *} \\
(0.027)\end{array}$ & $\begin{array}{l}0.139 * * \\
(0.013)\end{array}$ \\
\hline CAPEXP & & & $\begin{array}{l}-0.006^{*} \\
(0.067)\end{array}$ & $\begin{array}{l}0.018 * * * \\
(0.007)\end{array}$ & $\begin{array}{l}0.264 * * * \\
(0.000)\end{array}$ & $\begin{array}{l}0.418^{* * *} \\
(0.009)\end{array}$ & $\begin{array}{l}0.234 * * * \\
(0.000)\end{array}$ & $\begin{array}{l}0.218^{* * *} \\
(0.000)\end{array}$ \\
\hline Leverage & & $\begin{array}{l}-0.010^{* *} \\
(0.011)\end{array}$ & $\begin{array}{l}-0.001 \\
(0.181)\end{array}$ & $\begin{array}{l}-0.006 * * * \\
(0.002)\end{array}$ & $\begin{array}{l}{ }^{*} 0.075^{* * *} \\
(0.000)\end{array}$ & $\begin{array}{l}0.064 \\
(0.176)\end{array}$ & $\begin{array}{l}0.080 * * * \\
(0.000)\end{array}$ & $\begin{array}{l}0.080^{* * *} \\
(0.000)\end{array}$ \\
\hline Capital Intensity & $\begin{array}{l}0.132 * * * \\
(0.000)\end{array}$ & & & & & & & \\
\hline Depr./Total Assets & $\begin{array}{l}-0.096 \\
(0.334)\end{array}$ & & & & & & & \\
\hline $\begin{array}{l}\text { Pay Director Equity- } \\
\text { based compensation }\end{array}$ & $\begin{array}{l}0.011^{* *} \\
(0.017)\end{array}$ & $\begin{array}{l}-0.001 \\
(0.321)\end{array}$ & $\begin{array}{l}-0.000 \\
(0.553)\end{array}$ & $\begin{array}{l}0.002 * * * \\
(0.004)\end{array}$ & $\begin{array}{l}0.008^{*} \\
(0.063)\end{array}$ & $\begin{array}{l}0.003 \\
(0.882)\end{array}$ & $\begin{array}{l}0.007 * \\
(0.089)\end{array}$ & $\begin{array}{l}0.007^{*} \\
(0.077)\end{array}$ \\
\hline $\begin{array}{l}\text { Activist Institutional } \\
\text { Holding }(\%)\end{array}$ & $\begin{array}{l}-0.291 * * \\
(0.035)\end{array}$ & $\begin{array}{l}-0.047 \\
(0.240)\end{array}$ & $\begin{array}{l}0.027 * * \\
(0.028)\end{array}$ & $\begin{array}{l}-0.013 \\
(0.517)\end{array}$ & $\begin{array}{l}-0.123 \\
(0.352)\end{array}$ & $\begin{array}{l}1.710 * * * \\
(0.001)\end{array}$ & $\begin{array}{l}-0.286^{* *} \\
(0.015)\end{array}$ & $\begin{array}{l}-0.300 * * * \\
(0.008)\end{array}$ \\
\hline $\begin{array}{l}\text { CEO Cash } \\
\text { Compensation }\end{array}$ & $\begin{array}{l}0.016^{* * *} \\
(0.006)\end{array}$ & $\begin{array}{l}-0.004 * * \\
(0.046)\end{array}$ & $\begin{array}{l}0.000 \\
(0.753)\end{array}$ & $\begin{array}{l}0.003 * * * \\
(0.000)\end{array}$ & $\begin{array}{l}-0.015^{* * *} \\
(0.010)\end{array}$ & $\begin{array}{l}-0.101 * * * \\
(0.000)\end{array}$ & $\begin{array}{l}-0.009^{*} \\
(0.072)\end{array}$ & $\begin{array}{l}-0.007 \\
(0.124)\end{array}$ \\
\hline
\end{tabular}


Table B.2.3 Continued

\begin{tabular}{|c|c|c|c|c|c|c|c|c|}
\hline \multicolumn{9}{|c|}{ Firm Characteristics (Continued) } \\
\hline \multirow{2}{*}{$\begin{array}{l}\text { CEO Compensation } \\
\text { Delta }\end{array}$} & $-0.006^{* *}$ & -0.001 & 0.000 & $0.001 *$ & 0.002 & 0.027 & 0.000 & -0.000 \\
\hline & $(0.030)$ & $(0.392)$ & $(0.849)$ & $(0.054)$ & $(0.359)$ & $(0.004)$ & $(0.982)$ & $(0.855)$ \\
\hline \multirow{2}{*}{$\begin{array}{l}\text { CEO Compensation } \\
\text { Vega }\end{array}$} & $-0.023 * * *$ & -0.000 & $-0.002 * * *$ & $-0.002 *$ & $-0.011^{*}$ & $-0.080 * * *$ & $-0.009^{*}$ & -0.008 \\
\hline & $(0.000)$ & $(0.821)$ & $(0.001)$ & $(0.083)$ & $(0.064)$ & $(0.000)$ & $(0.077)$ & $(0.115)$ \\
\hline \multirow[t]{2}{*}{ Herfindhal Index } & $0.064 * *$ & -0.003 & 0.002 & $0.017 * * *$ & $-0.082 * * *$ & $-0.393 * * *$ & $-0.055^{* *}$ & $-0.051 * *$ \\
\hline & $(0.036)$ & $(0.771)$ & $(0.348)$ & $(0.000)$ & $(0.004)$ & & $(0.030)$ & $(0.037)$ \\
\hline \multicolumn{9}{|l|}{ CEO Characteristics } \\
\hline \multirow[t]{2}{*}{$\operatorname{Ln}(\mathrm{CEO}$ Tenure+1) } & 0.005 & $-0.005^{* *}$ & ${ }^{k}-0.000$ & $-0.001 * *$ & 0.001 & -0 . & -0. & -0 \\
\hline & $(0.116)$ & $(0.000)$ & $(0.228)$ & $(0.013)$ & $(0.690)$ & $(0.869)$ & $(0.654)$ & $(0.465)$ \\
\hline \multirow[t]{2}{*}{ CEO Age } & $-0.092 * * *$ & $-0.009^{*}$ & $-0.006^{* * *}$ & -0.004 & $-0.049 * * *$ & 0.088 & $-0.051 * * *$ & $-0.052 * * *$ \\
\hline & $(0.000)$ & $(0.054)$ & $(0.000)$ & $(0.101)$ & $(0.001)$ & $(0.1$ & $(0.000)$ & $(0.000)$ \\
\hline \multirow[t]{2}{*}{$\operatorname{MBA}(0 / 1)$} & $0.014 * * *$ & $-0.002 * *$ & $-0.001 * * *$ & -0.000 & $-0.008 * *$ & 0.004 & $-0.008 * * *$ & $-0.008 * * *$ \\
\hline & $(0.000)$ & $(0.030)$ & $(0.000)$ & $(0.353)$ & $(0.014)$ & $(0.783)$ & $(0.007)$ & $(0.005)$ \\
\hline \multirow[t]{2}{*}{ Founder $(0 / 1)$} & $0.015 * *$ & $-0.004 * *$ & -0.000 & $-0.003 * * *$ & $0.019 * * *$ & $0.046^{* *}$ & $0.017 * * *$ & $0.016 * * *$ \\
\hline & $(0.013)$ & $(0.043)$ & $(0.665)$ & $(0.002)$ & $(0.001)$ & $(0$. & $(0.001)$ & $(0.001)$ \\
\hline \multirow[t]{2}{*}{ \# Functional Areas } & $-0.005 * *$ & $-0.001 *$ & 0.000 & $-0.001 * *$ & $0.004^{* *}$ & $0.015^{* *}$ & 0.002 & 0.002 \\
\hline & $(0.019)$ & $(0.052)$ & $(0.100)$ & $(0.013)$ & $(0.038)$ & $(0.035)$ & $(0.156)$ & $(0.327)$ \\
\hline Has Finance & $0.012 * * *$ & $-0.005 * * *$ & ${ }^{k}-0.000$ & -0.001 & 0.000 & -0.008 & 0.001 & 0.001 \\
\hline Background (0/1) & $(0.003)$ & $(0.000)$ & $(0.714)$ & $(0.319)$ & $(0.953)$ & $(0.589)$ & $(0.757)$ & $(0.779)$ \\
\hline \multirow[t]{2}{*}{ Constant } & $0.333 * * *$ & $0.097 * * *$ & $0.024 * * *$ & 0.012 & $0.690 * * *$ & $0.857 * * *$ & $0.668 * * *$ & $0.657 * * *$ \\
\hline & $(0.000)$ & $(0.000)$ & $(0.000)$ & $(0.194)$ & $(0.000)$ & $(0.000)$ & $(0.000)$ & $(0.000)$ \\
\hline Year Dummies & Yes & Yes & Yes & Yes & Yes & Yes & Yes & Yes \\
\hline Industry Dummies & Yes & Yes & Yes & Yes & Yes & Yes & Yes & Yes \\
\hline Observations & 4826 & 5029 & 1465 & 5074 & 4693 & 4693 & 4693 & 4693 \\
\hline Lambda & -0.038 & 0.010 & 0.000 & -0.001 & 0.003 & 0.053 & -0.002 & -0.003 \\
\hline$p$-value & 0.000 & 0.000 & 0.378 & 0.512 & 0.610 & 0.021 & 0.752 & 0.519 \\
\hline
\end{tabular}




\section{Table B.2.4: A Subsample analysis of CEOs with different tenure lengths}

This table presents results for firm policies and risk for CEOs that have been the CEO of their current firms at least five or three years. Panel A presents the post-turnover policies in the first three years for CEOs who have been the $\mathrm{CEO}$ for three or more years. Panel B presents the post-turnover policies in the first five years for CEOs who have been the CEO for five or more years. The dependent variables are listed at the top of each column. Refer to Table 1 and Appendix A for variable definitions. Pre-turnover firm policies are the respective firm policies in the year before the CEO turnover year. The predicted signs for the CEO employment history proxies are presented in parenthesis at the top of each column. I report $p$-values based on robust standard errors clustered at the firm level in parenthesis.**, ${ }^{* *}$, and $*$ indicate significance at the 1,5 , and $10 \%$ levels, respectively.

Panel A. Post-turnover Policies in the first three years for CEOs with $C E O$ tenure $>=3$ years

\begin{tabular}{|c|c|c|c|c|c|c|c|c|}
\hline & Leverage & CAPEXP & $R \& D$ & Adv. & $\begin{array}{c}\text { Total Risk } \\
\text { (Ann. Daily } \\
\text { Stock } \\
\text { Return Std.) }\end{array}$ & $\begin{array}{l}\text { Market } \\
\text { Risk } \\
\text { (CAPM) }\end{array}$ & $\begin{array}{c}\text { Firm- } \\
\text { specific } \\
\text { Risk } \\
\text { (CAPM) }\end{array}$ & $\begin{array}{c}\text { Firm- } \\
\text { specific } \\
\text { Risk } \\
\text { (4- Factor) }\end{array}$ \\
\hline & $(+)$ & $(-)$ & $(+)$ & $(+)$ & $(+)$ & $(+)$ & $(+)$ & $(+)$ \\
\hline \#Employers & $\begin{array}{l}0.010^{* *} \\
(0.048)\end{array}$ & $\begin{array}{c}-0.005 * * * \\
(0.001)\end{array}$ & $\begin{array}{l}-0.016^{*} \\
(0.055)\end{array}$ & $\begin{array}{c}0.000 \\
(0.789)\end{array}$ & $\begin{array}{c}0.012 \\
(0.108)\end{array}$ & $\begin{array}{l}-0.015 \\
(0.316)\end{array}$ & $\begin{array}{l}0.012^{*} \\
(0.079)\end{array}$ & $\begin{array}{l}0.012^{*} \\
(0.076)\end{array}$ \\
\hline $\begin{array}{l}\text { \#Employers*Industry } \\
\text { Homogeneity }\end{array}$ & & & $\begin{array}{l}0.071 * \\
(0.085)\end{array}$ & & & & & \\
\hline \multicolumn{9}{|l|}{ Firm Characteristics } \\
\hline Pre-turnover Policy & $\begin{array}{c}0.505 * * * \\
(0.000)\end{array}$ & $\begin{array}{c}0.560 * * * \\
(0.000)\end{array}$ & $\begin{array}{c}0.693 * * * \\
(0.000)\end{array}$ & $\begin{array}{c}0.760 * * * \\
(0.000)\end{array}$ & $\begin{array}{c}0.339 * * * \\
(0.000)\end{array}$ & $\begin{array}{c}0.420 * * * \\
(0.000)\end{array}$ & $\begin{array}{c}0.347 * * * \\
(0.000)\end{array}$ & $\begin{array}{c}0.348^{* * *} \\
(0.000)\end{array}$ \\
\hline $\ln$ (Total Sales) & $\begin{array}{c}0.024 * * * \\
(0.000)\end{array}$ & $\begin{array}{c}-0.003 * * \\
(0.027)\end{array}$ & $\begin{array}{l}-0.001 \\
(0.168)\end{array}$ & $\begin{array}{c}0.000 \\
(0.506)\end{array}$ & $\begin{array}{c}-0.010 * * \\
(0.010)\end{array}$ & $\begin{array}{l}-0.021^{*} \\
(0.073)\end{array}$ & $\begin{array}{c}-0.011 * * * \\
(0.001)\end{array}$ & $\begin{array}{c}-0.011^{* * *} \\
(0.001)\end{array}$ \\
\hline Firm Age & $\begin{array}{l}-0.005 \\
(0.424)\end{array}$ & $\begin{array}{l}-0.001 \\
(0.471)\end{array}$ & $\begin{array}{c}-0.003 * * * \\
(0.007)\end{array}$ & $\begin{array}{l}0.000 \\
(0.787)\end{array}$ & $\begin{array}{c}-0.029 * * * \\
(0.000)\end{array}$ & $\begin{array}{c}-0.076^{* * *} \\
(0.002)\end{array}$ & $\begin{array}{c}-0.025^{* * *} \\
(0.000)\end{array}$ & $\begin{array}{c}-0.024 * * * \\
(0.000)\end{array}$ \\
\hline $\begin{array}{l}\text { Operating Return on } \\
\text { Assets }\end{array}$ & $\begin{array}{c}-0.462 * * * \\
(0.000)\end{array}$ & & & & $\begin{array}{c}-0.273 * * * \\
(0.000)\end{array}$ & $\begin{array}{l}-0.500^{*} \\
(0.058)\end{array}$ & $\begin{array}{c}-0.230^{* * *} \\
(0.000)\end{array}$ & $\begin{array}{c}-0.210^{* * *} \\
(0.000)\end{array}$ \\
\hline Surplus Cash & & $\begin{array}{c}0.022 \\
(0.202)\end{array}$ & $\begin{array}{c}0.126^{* * *} \\
(0.000)\end{array}$ & $\begin{array}{l}-0.005 \\
(0.474)\end{array}$ & & & & \\
\hline Tobin's Q & $\begin{array}{c}-0.012^{* * *} \\
(0.001)\end{array}$ & $\begin{array}{c}0.000 \\
(0.978)\end{array}$ & $\begin{array}{l}-0.002 \\
(0.148)\end{array}$ & $\begin{array}{c}0.001 \\
(0.115)\end{array}$ & $\begin{array}{c}0.001 \\
(0.737)\end{array}$ & $\begin{array}{c}0.015 \\
(0.376)\end{array}$ & $\begin{array}{l}-0.001 \\
(0.748)\end{array}$ & $\begin{array}{l}-0.002 \\
(0.636)\end{array}$ \\
\hline R\&D/Total Assets & $\begin{array}{c}-0.317 * * * \\
(0.000)\end{array}$ & $\begin{array}{l}-0.071^{*} \\
(0.052)\end{array}$ & & $\begin{array}{l}-0.020^{*} \\
(0.095)\end{array}$ & $\begin{array}{c}0.453 * * * \\
(0.000)\end{array}$ & $\begin{array}{l}0.911^{* * *} \\
(0.009)\end{array}$ & $\begin{array}{c}0.410^{* * *} \\
(0.000)\end{array}$ & $\begin{array}{c}0.400 * * * \\
(0.000)\end{array}$ \\
\hline Adv./Total Assets & & $\begin{array}{c}0.020 \\
(0.618)\end{array}$ & $\begin{array}{c}-0.099 * * * \\
(0.010)\end{array}$ & & $\begin{array}{l}-0.040 \\
(0.783)\end{array}$ & $\begin{array}{l}-0.451 \\
(0.313)\end{array}$ & $\begin{array}{c}0.034 \\
(0.781)\end{array}$ & $\begin{array}{c}0.054 \\
(0.662)\end{array}$ \\
\hline CAPEXP & & & $\begin{array}{l}-0.010 \\
(0.658)\end{array}$ & $\begin{array}{c}0.012 \\
(0.222)\end{array}$ & $\begin{array}{l}0.197 * * \\
(0.016)\end{array}$ & $\begin{array}{c}0.251 \\
(0.381)\end{array}$ & $\begin{array}{c}0.197 * * * \\
(0.008)\end{array}$ & $\begin{array}{l}0.161 * * \\
(0.023)\end{array}$ \\
\hline Leverage & & $\begin{array}{l}-0.003 \\
(0.710)\end{array}$ & $\begin{array}{c}0.003 \\
(0.679)\end{array}$ & $\begin{array}{l}-0.004 \\
(0.165)\end{array}$ & $\begin{array}{l}0.053^{*} \\
(0.091)\end{array}$ & $\begin{array}{c}0.083 \\
(0.391)\end{array}$ & $\begin{array}{l}0.056^{*} \\
(0.057)\end{array}$ & $\begin{array}{l}0.057 * * \\
(0.047)\end{array}$ \\
\hline Industry Homogeneity & & & $\begin{array}{l}-0.222^{*} \\
(0.064)\end{array}$ & & & & & \\
\hline Capital Intensity & $\begin{array}{c}0.088^{* * *} \\
(0.001)\end{array}$ & & & & & & & \\
\hline Depr./Total Assets & $\begin{array}{l}-0.039 \\
(0.849)\end{array}$ & & & & & & & \\
\hline $\begin{array}{l}\text { Pay Director Equity- } \\
\text { based compensation }\end{array}$ & $\begin{array}{c}0.004 \\
(0.622)\end{array}$ & $\begin{array}{c}0.002 \\
(0.420)\end{array}$ & $\begin{array}{l}0.001 \\
(0.444)\end{array}$ & $\begin{array}{c}0.000 \\
(0.827)\end{array}$ & $\begin{array}{l}-0.000 \\
(0.983)\end{array}$ & $\begin{array}{l}-0.027 \\
(0.322)\end{array}$ & $\begin{array}{c}0.001 \\
(0.844)\end{array}$ & $\begin{array}{c}0.002 \\
(0.760)\end{array}$ \\
\hline $\begin{array}{l}\text { Activist Institutional } \\
\text { Holding }(\%)\end{array}$ & $\begin{array}{l}-0.185 \\
(0.427)\end{array}$ & $\begin{array}{l}-0.195^{*} \\
(0.059)\end{array}$ & $\begin{array}{l}0.144^{* *} \\
(0.029)\end{array}$ & $\begin{array}{l}-0.076 \\
(0.226)\end{array}$ & $\begin{array}{l}-0.119 \\
(0.643)\end{array}$ & $\begin{array}{c}1.361 \\
(0.113)\end{array}$ & $\begin{array}{l}-0.286 \\
(0.226)\end{array}$ & $\begin{array}{l}-0.286 \\
(0.213)\end{array}$ \\
\hline
\end{tabular}


Table B.2.4 Continued

\begin{tabular}{|c|c|c|c|c|c|c|c|c|}
\hline \multicolumn{9}{|c|}{ Firm Characteristics (Continued) } \\
\hline \multirow{2}{*}{$\begin{array}{l}\text { CEO Cash } \\
\text { Compensation }\end{array}$} & $0.022 * *$ & $-0.007 * *$ & $0.006^{*}$ & $0.004 * * *$ & -0.012 & $-0.077^{*}$ & -0.010 & -0.007 \\
\hline & $(0.041)$ & $(0.041)$ & $(0.062)$ & $(0.007)$ & $(0.307)$ & $(0.063)$ & $(0.329)$ & $(0.459)$ \\
\hline \multirow{2}{*}{$\begin{array}{l}\text { CEO Compensation } \\
\text { Delta }\end{array}$} & -0.004 & -0.000 & -0.000 & -0.000 & 0.010 & 0.043 & 0.008 & 0.007 \\
\hline & $(0.516)$ & $(0.804)$ & $(0.818)$ & $(0.978)$ & $(0.243)$ & $(0.105)$ & $(0.255)$ & $(0.338)$ \\
\hline \multirow{2}{*}{$\begin{array}{l}\text { CEO Compensation } \\
\text { Vega }\end{array}$} & $-0.034 * *$ & 0.003 & 0.003 & 0.000 & -0.022 & $-0.104 *$ & -0.020 & -0.018 \\
\hline & $(0.013)$ & $(0.454)$ & $(0.295)$ & $(0.999)$ & $(0.156)$ & $(0.050)$ & $(0.109)$ & $(0.143)$ \\
\hline \multirow[t]{2}{*}{ Herfindhal Index } & 0.055 & -0.012 & 0.008 & 0.012 & -0.041 & $-0.223^{*}$ & -0.028 & -0.028 \\
\hline & $(0.193)$ & $(0.221)$ & $(0.249)$ & $(0.139)$ & $(0.265)$ & $(0.060)$ & $(0.431)$ & $(0.415)$ \\
\hline \multicolumn{9}{|l|}{ CEO Characteristics } \\
\hline \multirow[t]{2}{*}{$\overline{\operatorname{Ln}(\mathrm{CEO} \text { Tenure }+1)}$} & 0.008 & $-0.007 * *$ & -0.003 & -0.001 & 0.014 & 0.022 & 0.004 & 0.004 \\
\hline & $(0.337)$ & $(0.013)$ & $(0.167)$ & $(0.382)$ & $(0.140)$ & $(0.510)$ & $(0.598)$ & $(0.645)$ \\
\hline \multirow[t]{2}{*}{ CEO Age } & -0.038 & -0.005 & $-0.021 * * *$ & 0.001 & $-0.110 * *$ & -0.065 & $-0.100 * * *$ & $-0.097^{* * *}$ \\
\hline & $(0.232)$ & $(0.652)$ & $(0.003)$ & $(0.887)$ & $(0.010)$ & $(0.593)$ & $(0.006)$ & $(0.007)$ \\
\hline \multirow[t]{2}{*}{$\operatorname{MBA}(0 / 1)$} & 0.010 & $-0.005^{* *}$ & 0.002 & -0.001 & -0.006 & 0.001 & -0.005 & -0.005 \\
\hline & $(0.219)$ & $(0.029)$ & $(0.340)$ & $(0.287)$ & $(0.453)$ & $(0.960)$ & $(0.495)$ & $(0.458)$ \\
\hline \multirow[t]{2}{*}{ Founder $(0 / 1)$} & 0.008 & -0.004 & -0.003 & 0.000 & -0.004 & $-0.102 * *$ & 0.002 & 0.004 \\
\hline & $(0.580)$ & $(0.427)$ & $(0.400)$ & $(0.834)$ & $(0.811)$ & $(0.039)$ & $(0.887)$ & $(0.796)$ \\
\hline \multirow[t]{2}{*}{ \# Functional Areas } & $-0.006^{*}$ & -0.001 & 0.001 & 0.000 & 0.001 & 0.016 & 0.001 & 0.000 \\
\hline & $(0.099)$ & $(0.260)$ & $(0.503)$ & $(0.987)$ & $(0.894)$ & $(0.251)$ & $(0.873)$ & $(0.965)$ \\
\hline \multirow{2}{*}{$\begin{array}{l}\text { Has Finance } \\
\text { Background }(0 / 1)\end{array}$} & 0.009 & 0.003 & $-0.005^{*}$ & -0.000 & -0.003 & -0.021 & -0.002 & -0.002 \\
\hline & $(0.375)$ & $(0.271)$ & $(0.052)$ & $(0.910)$ & $(0.734)$ & $(0.491)$ & $(0.842)$ & $(0.772)$ \\
\hline \multirow[t]{2}{*}{ Constant } & 0.054 & $0.124 * * *$ & $0.145^{* * *}$ & -0.003 & $0.799 * * *$ & $1.379 * * *$ & $0.761^{* * *}$ & $0.736^{* * *}$ \\
\hline & $(0.667)$ & $(0.004)$ & $(0.000)$ & $(0.856)$ & $(0.000)$ & $(0.007)$ & $(0.000)$ & $(0.000)$ \\
\hline Year Dummies & Yes & Yes & Yes & Yes & Yes & Yes & Yes & Yes \\
\hline Industry Dummies & Yes & Yes & Yes & Yes & Yes & Yes & Yes & Yes \\
\hline \multirow{2}{*}{$\begin{array}{l}\text { Observations } \\
\text { R-square }\end{array}$} & 1791 & 1834 & 1777 & 1861 & 1774 & 1774 & 1774 & 1774 \\
\hline & 0.662 & 0.461 & 0.764 & 0.747 & 0.664 & 0.464 & 0.684 & 0.683 \\
\hline \multirow{2}{*}{$\begin{array}{l}\text { Hansen's J-test (p-value) } \\
\text { First Stage } F \text {-stat for } \\
\text { \#Emplovers }\end{array}$} & 0.420 & 0.726 & 0.356 & 0.675 & 0.171 & 0.73 & 0.214 & 0.253 \\
\hline & 75.34 & 53.42 & 42.82 & 53.87 & 44.65 & 70.1 & 60.95 & 60.96 \\
\hline \multicolumn{3}{|c|}{$\begin{array}{l}\text { First Stage F-stat for \#Employers * Industry } \\
\text { Homogeneity }\end{array}$} & 24.9 & & & & & \\
\hline
\end{tabular}

Panel B. Post-turnover Policies in the first five years for CEOS with CEO tenure $>=5$ years

\begin{tabular}{|c|c|c|c|c|c|c|c|c|}
\hline & Leverage & CAPEXP & $R \& D$ & Adv. & $\begin{array}{c}\text { Total Risk } \\
\text { (Ann. Daily } \\
\text { Stock } \\
\text { Return Std.) }\end{array}$ & $\begin{array}{c}\text { Market } \\
\text { Risk } \\
\text { (CAPM) }\end{array}$ & $\begin{array}{c}\text { Firm- } \\
\text { specific } \\
\text { Risk } \\
\text { (CAPM) }\end{array}$ & $\begin{array}{c}\text { Firm- } \\
\text { specific } \\
\text { Risk } \\
\text { (4- Factor) }\end{array}$ \\
\hline \#Employers & $\begin{array}{c}(+) \\
0.021^{* * *} \\
(0.007)\end{array}$ & $\begin{array}{c}(-) \\
-0.007^{* * *} \\
(0.002)\end{array}$ & $\begin{array}{c}(+) \\
-0.013 \\
(0.101)\end{array}$ & $\begin{array}{c}(+) \\
0.002 * \\
(0.085)\end{array}$ & $\begin{array}{c}(+) \\
0.007 \\
(0.200)\end{array}$ & $\begin{array}{c}(+) \\
-0.014 \\
(0.438)\end{array}$ & $\begin{array}{c}(+) \\
0.007^{*} \\
(0.098)\end{array}$ & $\begin{array}{c}(+) \\
0.007^{*} \\
(0.084)\end{array}$ \\
\hline $\begin{array}{l}\text { \#Employers*Industry } \\
\text { Homogeneity }\end{array}$ & & & $\begin{array}{c}0.060 \\
(0.135)\end{array}$ & & & & & \\
\hline \multicolumn{9}{|l|}{ Firm Characteristics } \\
\hline Pre-turnover Policy & $\begin{array}{c}0.452 * * * \\
(0.000)\end{array}$ & $\begin{array}{c}0.549 * * * \\
(0.000)\end{array}$ & $\begin{array}{c}0.631^{* * *} \\
(0.000)\end{array}$ & $\begin{array}{c}0.639 * * * \\
(0.000)\end{array}$ & $\begin{array}{c}0.322 * * * \\
(0.000)\end{array}$ & $\begin{array}{c}0.329 * * * \\
(0.000)\end{array}$ & $\begin{array}{c}0.327 * * * \\
(0.000)\end{array}$ & $\begin{array}{c}0.320 * * * \\
(0.000)\end{array}$ \\
\hline
\end{tabular}


Table B.2.4 Continued.

\begin{tabular}{|c|c|c|c|c|c|c|c|c|}
\hline \multicolumn{9}{|c|}{ Firm Characteristics (Continued) } \\
\hline $\ln$ (Total Sales) & $\begin{array}{c}0.034 * * * \\
(0.000)\end{array}$ & $\begin{array}{c}-0.003^{*} \\
(0.063)\end{array}$ & $\begin{array}{l}-0.001 \\
(0.316)\end{array}$ & $\begin{array}{c}0.002 * * * \\
(0.001)\end{array}$ & $\begin{array}{l}-0.014 * * * \\
(0.000)\end{array}$ & $\begin{array}{c}-0.029^{* *} \\
(0.023)\end{array}$ & $\begin{array}{c}-0.015^{* * *} \\
(0.000)\end{array}$ & $\begin{array}{c}-0.015^{* * *} \\
(0.000)\end{array}$ \\
\hline Firm Age & $\begin{array}{c}0.005 \\
(0.545)\end{array}$ & $\begin{array}{l}-0.002 \\
(0.360)\end{array}$ & $\begin{array}{l}-0.003^{*} \\
(0.088)\end{array}$ & $\begin{array}{c}0.000 \\
(0.613)\end{array}$ & $\begin{array}{c}-0.025 * * * \\
(0.000)\end{array}$ & $\begin{array}{c}-0.066^{* *} \\
(0.014)\end{array}$ & $\begin{array}{c}-0.023 * * * \\
(0.000)\end{array}$ & $\begin{array}{c}-0.023 * * * \\
(0.000)\end{array}$ \\
\hline $\begin{array}{l}\text { Operating Return on } \\
\text { Assets }\end{array}$ & $\begin{array}{c}-0.518^{* * *} \\
(0.000)\end{array}$ & & & & $\begin{array}{c}-0.373 * * * \\
(0.000)\end{array}$ & $\begin{array}{c}-0.868 * * * \\
(0.001)\end{array}$ & $\begin{array}{c}-0.301 * * * \\
(0.000)\end{array}$ & $\begin{array}{c}-0.276 * * * \\
(0.000)\end{array}$ \\
\hline Surplus Cash & & $\begin{array}{l}0.036^{* *} \\
(0.023)\end{array}$ & $\begin{array}{c}0.141 * * * \\
(0.000)\end{array}$ & $\begin{array}{l}-0.017 \\
(0.251)\end{array}$ & & & & \\
\hline Tobin's Q & $\begin{array}{c}-0.008^{* *} \\
(0.030)\end{array}$ & $\begin{array}{l}-0.000 \\
(0.930)\end{array}$ & $\begin{array}{l}-0.002 \\
(0.244)\end{array}$ & $\begin{array}{l}0.002 * * \\
(0.015)\end{array}$ & $\begin{array}{c}0.002 \\
(0.693)\end{array}$ & $\begin{array}{c}0.023 \\
(0.152)\end{array}$ & $\begin{array}{l}-0.001 \\
(0.847)\end{array}$ & $\begin{array}{l}-0.001 \\
(0.791)\end{array}$ \\
\hline $\mathrm{R} \& \mathrm{D} /$ Total Assets & $\begin{array}{c}-0.368 * * * \\
(0.000)\end{array}$ & $\begin{array}{c}-0.106 * * * \\
(0.006)\end{array}$ & & $\begin{array}{c}-0.036^{* *} \\
(0.019)\end{array}$ & $\begin{array}{c}0.614 * * * \\
(0.000)\end{array}$ & $\begin{array}{c}1.310^{* * *} \\
(0.001)\end{array}$ & $\begin{array}{c}0.520^{* * *} \\
(0.000)\end{array}$ & $\begin{array}{c}0.492 * * * \\
(0.000)\end{array}$ \\
\hline Adv./Total Assets & & $\begin{array}{c}0.054 \\
(0.284)\end{array}$ & $\begin{array}{c}-0.099 * * \\
(0.015)\end{array}$ & & $\begin{array}{l}-0.088 \\
(0.517)\end{array}$ & $\begin{array}{c}-0.972 * * \\
(0.034)\end{array}$ & $\begin{array}{c}0.006 \\
(0.959)\end{array}$ & $\begin{array}{c}0.032 \\
(0.782)\end{array}$ \\
\hline CAPEXP & & & $\begin{array}{l}-0.025 \\
(0.382)\end{array}$ & $\begin{array}{l}0.024 * * \\
(0.035)\end{array}$ & $\begin{array}{l}0.180^{* *} \\
(0.016)\end{array}$ & $\begin{array}{c}0.072 \\
(0.808)\end{array}$ & $\begin{array}{c}0.173^{* * *} \\
(0.009)\end{array}$ & $\begin{array}{l}0.138^{* *} \\
(0.029)\end{array}$ \\
\hline Leverage & & $\begin{array}{l}-0.012 \\
(0.260)\end{array}$ & $\begin{array}{c}0.003 \\
(0.655)\end{array}$ & $\begin{array}{c}-0.008^{* *} \\
(0.037)\end{array}$ & $\begin{array}{c}0.042 \\
(0.172)\end{array}$ & $\begin{array}{l}-0.086 \\
(0.373)\end{array}$ & $\begin{array}{l}0.050^{*} \\
(0.087)\end{array}$ & $\begin{array}{l}0.052^{*} \\
(0.066)\end{array}$ \\
\hline Industry Homogeneity & & & $\begin{array}{l}-0.187^{*} \\
(0.100)\end{array}$ & & & & & \\
\hline Capital Intensity & $\begin{array}{l}0.079 * * \\
(0.017)\end{array}$ & & & & & & & \\
\hline Depr./Total Assets & $\begin{array}{l}-0.103 \\
(0.673)\end{array}$ & & & & & & & \\
\hline $\begin{array}{l}\text { Pay Director Equity- } \\
\text { based compensation }\end{array}$ & $\begin{array}{c}0.003 \\
(0.721)\end{array}$ & $\begin{array}{l}0.003 \\
(0.375)\end{array}$ & $\begin{array}{c}0.002 \\
(0.339)\end{array}$ & $\begin{array}{c}0.002 \\
(0.304)\end{array}$ & $\begin{array}{c}0.004 \\
(0.648)\end{array}$ & $\begin{array}{c}0.019 \\
(0.476)\end{array}$ & $\begin{array}{c}0.004 \\
(0.645)\end{array}$ & $\begin{array}{c}0.004 \\
(0.612)\end{array}$ \\
\hline $\begin{array}{l}\text { Activist Institutional } \\
\text { Holding (\%) }\end{array}$ & $\begin{array}{l}-0.406 \\
(0.108)\end{array}$ & $\begin{array}{l}-0.200^{*} \\
(0.059)\end{array}$ & $\begin{array}{c}0.090 \\
(0.137)\end{array}$ & $\begin{array}{l}-0.064 \\
(0.261)\end{array}$ & $\begin{array}{l}-0.119 \\
(0.649)\end{array}$ & $\begin{array}{l}1.581 * \\
(0.073)\end{array}$ & $\begin{array}{l}-0.314 \\
(0.201)\end{array}$ & $\begin{array}{l}-0.342 \\
(0.157)\end{array}$ \\
\hline $\begin{array}{l}\text { CEO Cash } \\
\text { Compensation }\end{array}$ & $\begin{array}{c}0.034 * * * \\
(0.004)\end{array}$ & $\begin{array}{c}-0.012 * * * \\
(0.001)\end{array}$ & $\begin{array}{l}0.007 * \\
(0.053)\end{array}$ & $\begin{array}{c}0.005 * * * \\
(0.004)\end{array}$ & $\begin{array}{l}-0.018^{*} \\
(0.097)\end{array}$ & $\begin{array}{c}-0.139 * * * \\
(0.000)\end{array}$ & $\begin{array}{l}-0.011 \\
(0.231)\end{array}$ & $\begin{array}{l}-0.009 \\
(0.334)\end{array}$ \\
\hline $\begin{array}{l}\text { CEO Compensation } \\
\text { Delta }\end{array}$ & $\begin{array}{l}-0.004 \\
(0.357)\end{array}$ & $\begin{array}{l}-0.001 \\
(0.228)\end{array}$ & $\begin{array}{l}-0.000 \\
(0.687)\end{array}$ & $\begin{array}{c}0.000 \\
(0.853)\end{array}$ & $\begin{array}{c}0.006 \\
(0.278)\end{array}$ & $\begin{array}{c}0.027 \\
(0.199)\end{array}$ & $\begin{array}{c}0.003 \\
(0.471)\end{array}$ & $\begin{array}{c}0.002 \\
(0.581)\end{array}$ \\
\hline $\begin{array}{l}\text { CEO Compensation } \\
\text { Vega }\end{array}$ & $\begin{array}{c}-0.059 * * * \\
(0.000)\end{array}$ & $\begin{array}{l}0.007^{*} \\
(0.080)\end{array}$ & $\begin{array}{c}0.003 \\
(0.376)\end{array}$ & $\begin{array}{l}-0.004 \\
(0.134)\end{array}$ & $\begin{array}{l}-0.018 \\
(0.171)\end{array}$ & $\begin{array}{l}-0.089^{*} \\
(0.072)\end{array}$ & $\begin{array}{l}-0.016 \\
(0.150)\end{array}$ & $\begin{array}{l}-0.012 \\
(0.244)\end{array}$ \\
\hline Herfindhal Index & $\begin{array}{c}0.111 \\
(0.114)\end{array}$ & $\begin{array}{l}-0.027 \\
(0.128)\end{array}$ & $\begin{array}{c}0.009 \\
(0.449)\end{array}$ & $\begin{array}{l}0.021^{*} \\
(0.059)\end{array}$ & $\begin{array}{l}-0.044 \\
(0.387)\end{array}$ & $\begin{array}{l}-0.266 \\
(0.150)\end{array}$ & $\begin{array}{l}-0.025 \\
(0.591)\end{array}$ & $\begin{array}{l}-0.023 \\
(0.589)\end{array}$ \\
\hline CEO Char & & & & & & & & \\
\hline $\operatorname{Ln}(\mathrm{CEO}$ Tenure +1$)$ & $\begin{array}{c}0.014 \\
(0.133)\end{array}$ & $\begin{array}{l}-0.003 \\
(0.270)\end{array}$ & $\begin{array}{l}-0.001 \\
(0.621)\end{array}$ & $\begin{array}{l}-0.000 \\
(0.895)\end{array}$ & $\begin{array}{c}0.031 * * * \\
(0.002)\end{array}$ & $\begin{array}{c}0.017 \\
(0.567)\end{array}$ & $\begin{array}{l}0.021 * * \\
(0.019)\end{array}$ & $\begin{array}{l}0.018^{* *} \\
(0.033)\end{array}$ \\
\hline CEO Age & $\begin{array}{l}-0.031 \\
(0.485)\end{array}$ & $\begin{array}{c}0.003 \\
(0.817)\end{array}$ & $\begin{array}{c}-0.025^{* * *} \\
(0.004)\end{array}$ & $\begin{array}{l}-0.003 \\
(0.634)\end{array}$ & $\begin{array}{c}-0.104 * * \\
(0.021)\end{array}$ & $\begin{array}{l}-0.066 \\
(0.625)\end{array}$ & $\begin{array}{c}-0.098^{* *} \\
(0.016)\end{array}$ & $\begin{array}{c}-0.097 * * \\
(0.014)\end{array}$ \\
\hline $\operatorname{MBA}(0 / 1)$ & $\begin{array}{c}0.009 \\
(0.408)\end{array}$ & $\begin{array}{l}-0.004 \\
(0.182)\end{array}$ & $\begin{array}{c}0.003 \\
(0.180)\end{array}$ & $\begin{array}{l}-0.001 \\
(0.563)\end{array}$ & $\begin{array}{c}-0.019 * * \\
(0.027)\end{array}$ & $\begin{array}{l}-0.029 \\
(0.346)\end{array}$ & $\begin{array}{c}-0.015^{* *} \\
(0.043)\end{array}$ & $\begin{array}{c}-0.016^{* *} \\
(0.033)\end{array}$ \\
\hline Founder $(0 / 1)$ & $\begin{array}{c}0.027 \\
(0.126)\end{array}$ & $\begin{array}{l}-0.004 \\
(0.479)\end{array}$ & $\begin{array}{l}-0.004 \\
(0.374)\end{array}$ & $\begin{array}{c}0.003 \\
(0.195)\end{array}$ & $\begin{array}{c}0.009 \\
(0.559)\end{array}$ & $\begin{array}{l}-0.013 \\
(0.799)\end{array}$ & $\begin{array}{c}0.009 \\
(0.489)\end{array}$ & $\begin{array}{c}0.009 \\
(0.475)\end{array}$ \\
\hline
\end{tabular}


Table B.2.4. Continued

\begin{tabular}{lcccccccc}
\hline CEO Characteristics (Continued) & & & & & & & \\
\# Functional Areas & -0.006 & $-0.003^{* *}$ & 0.001 & -0.000 & 0.000 & 0.002 & 0.000 & -0.001 \\
& $(0.228)$ & $(0.049)$ & $(0.628)$ & $(0.630)$ & $(0.951)$ & $(0.898)$ & $(0.966)$ & $(0.871)$ \\
Has Finance & 0.015 & 0.002 & $-0.007^{* *}$ & -0.002 & 0.005 & -0.001 & 0.004 & 0.003 \\
Background (0/1) & $(0.221)$ & $(0.496)$ & $(0.018)$ & $(0.366)$ & $(0.578)$ & $(0.979)$ & $(0.621)$ & $(0.677)$ \\
Constant & -0.079 & $0.106^{* *}$ & $0.150^{* * *}$ & -0.011 & $0.805^{* * *}$ & $1.633^{* * *}$ & $0.770^{* * *}$ & $0.770^{* * *}$ \\
& $(0.611)$ & $(0.032)$ & $(0.000)$ & $(0.592)$ & $(0.000)$ & $(0.003)$ & $(0.000)$ & $(0.000)$ \\
Year Dummies & Yes & Yes & Yes & Yes & Yes & Yes & Yes & Yes \\
Industry Dummies & Yes & Yes & Yes & Yes & Yes & Yes & Yes & Yes \\
Observations & 2095 & 2187 & 2117 & 2225 & 2068 & 2068 & 2068 & 2068 \\
R-square & 0.594 & 0.467 & 0.742 & 0.625 & 0.658 & 0.425 & 0.680 & 0.677 \\
& & & & & & & & \\
Hansen's J-test (p-value) & 0.647 & 0.613 & 0.736 & 0.652 & 0.163 & 0.545 & 0.167 & 0.241 \\
First Stage F-stat for & 35.4 & 26.01 & 24.96 & 24.64 & 21.1 & 31.01 & 30.73 & 30.7 \\
\#Emplovers & & & & & & & & \\
First Stage F-stat for \#Employers * Industry & 15.79 & & & & & \\
Homogeneity & & & & & & & &
\end{tabular}




\section{Table B.2.5. The Number of Employers and Long-run Performance (Matched Sample)}

The table presents change in industry-median-adjusted accounting/stock performance following CEO turnovers for the subsample of CEOs that have worked for at least five employers. The matched sample is a subsample of CEOs that have worked for only one employer. Panel A presents results based on the nearest neighborhood match proposed in Abadie and Imbens (2002). The table reports the average treatment effect on the treated. Panel B presents results based on the match method proposed in Baber and Lyon (1996). The statistical significance in Panel B is based on the paired t-test. For variable definitions, refer to Appendix $\mathrm{A}$ and Table 1 . I report changes in performance for year -1 to +1 , year -1 to +2 , year -1 to +3 . Year 0 is the year of CEO turnover. \# Employers is the number of employer the CEO has worked for. Survival ratio is the number of CEOs who remain as CEOs for the year of interest divided by the total number of CEOs in that group at year 1 . Year 1 is one year after the year of CEO turn over. I indicate significance at the $1 \%, 5 \%$, and $10 \%$ levels with ***, **, and *, respectively.

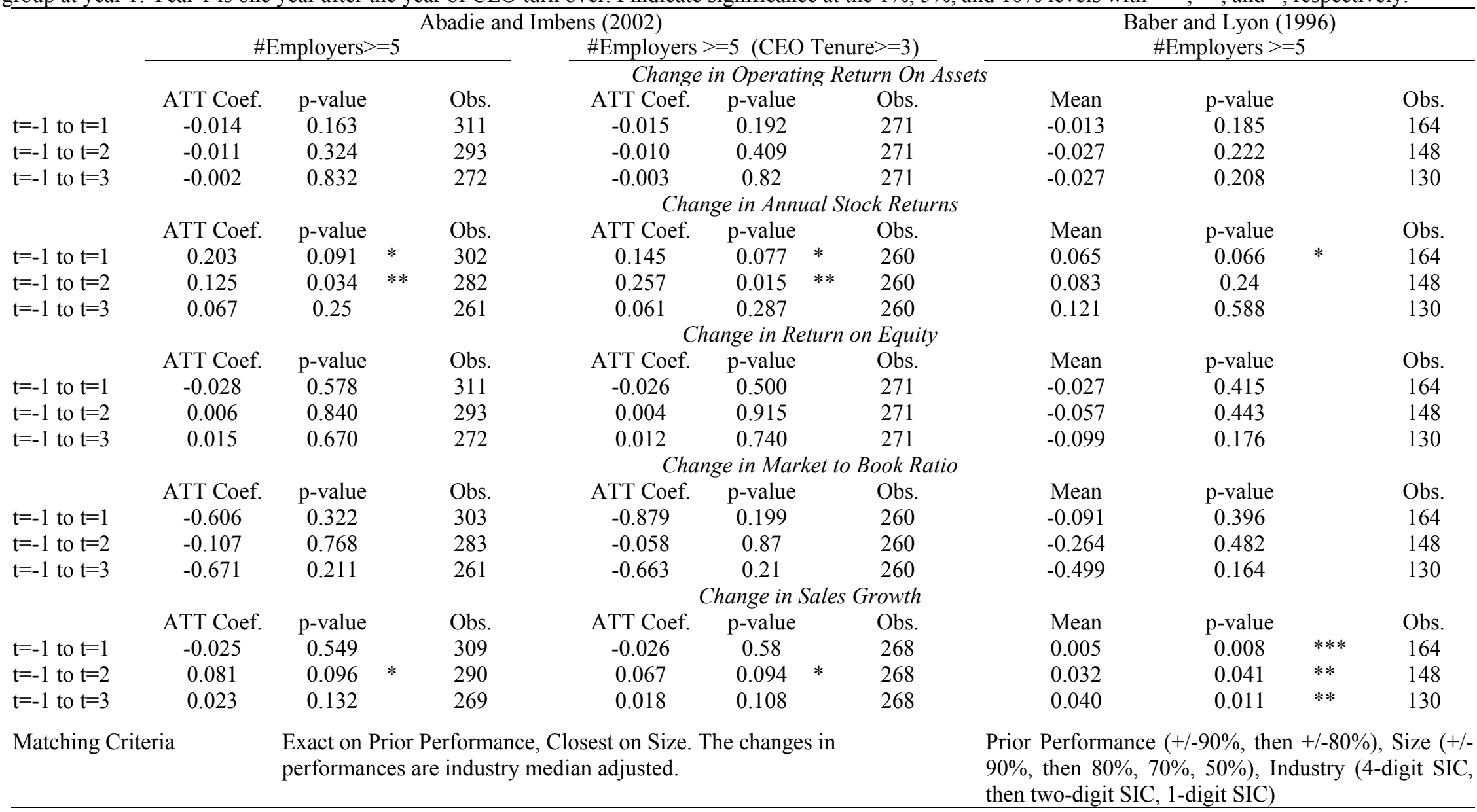




\section{Table B.3.1. Differences in Pre-turnover Firm Policies for CEOs with different employment histories}

This table presents differences in prior CEO characteristics and firm policies in the year prior to the year of CEO turnover for 714 CEOs in the CEO-firm match analysis. Refer to Tables 1 and 2 and Appendix A for variable definitions. Q1 includes CEOs in the bottom quartile and Q4 includes CEOs in the top quartile. Q4-Q1 is the difference in means (medians) between the top and the bottom quartiles. The differences in means and medians for the bottom and top quartiles are presented at the right side of the table. The statistical significance for difference in means is based on t-test and for difference in medians is based on the nonparametric signed rank test. Comparison based on \#Employers is presented in Table 3 . This table presents results based on the other four employment history variables. $* * *, * *$, and $*$ indicate significance at the 1,5 , and $10 \%$ levels, respectively.

\begin{tabular}{|c|c|c|c|c|c|c|c|c|c|c|}
\hline & \multicolumn{2}{|c|}{ Least Frequent } & \multicolumn{2}{|c|}{ Q2 } & \multicolumn{2}{|c|}{ Q3 } & \multicolumn{2}{|c|}{ Most Frequent } & \multicolumn{2}{|c|}{ Q4-Q1 } \\
\hline & Mean & Median & Mean & Median & Mean & Median & Mean & Median & Mean & Median \\
\hline \multicolumn{11}{|l|}{ Prior CEO Characteristics } \\
\hline Prior CEO Tenure & 11.026 & 8 & 10.195 & 7 & 8.598 & 7 & 7.961 & 6 & $-3.065 * * *$ & $-2 * * *$ \\
\hline Prior CEO Is Chairman & $81.42 \%$ & & $77.27 \%$ & & $78.72 \%$ & & $69.31 \%$ & & $-12.10 \% * *$ & \\
\hline Forced Turnover & $6.09 \%$ & & $9.02 \%$ & & $14.81 \%$ & & $16.90 \%$ & & $10.81 \% * * *$ & \\
\hline \multicolumn{11}{|l|}{ Board Characteristics } \\
\hline Board Insiders (\%) & 0.260 & 0.250 & 0.272 & 0.250 & 0.257 & 0.222 & 0.258 & 0.222 & -0.002 & -0.028 \\
\hline Board Size & 11.071 & 11 & 9.818 & 9 & 9.388 & 9 & 8.787 & 9 & $-2.284 * * *$ & $-2 * * *$ \\
\hline \multicolumn{11}{|l|}{ Firm Characteristics } \\
\hline Firm Size & 8.132 & 7.872 & 7.568 & 7.400 & 7.448 & 7.267 & 6.991 & 6.840 & $-1.141 * * *$ & $-1.032 * * *$ \\
\hline Firm Age & 78.957 & 80 & 59.955 & 51 & 53.804 & 44 & 50.465 & 39 & $-28.492 * * *$ & $-42 * * *$ \\
\hline Leverage & 0.231 & 0.198 & 0.188 & 0.156 & 0.197 & 0.161 & 0.179 & 0.121 & $-0.052 * *$ & $-0.077 * * *$ \\
\hline R\&D Exp./Total Assets & 0.019 & 0.005 & 0.025 & 0.000 & 0.031 & 0.007 & 0.037 & 0.007 & $0.018 * * *$ & $0.002 *$ \\
\hline Advertising/Total Assets & 0.014 & 0.000 & 0.012 & 0.000 & 0.009 & 0.000 & 0.016 & 0.000 & 0.002 & 0.000 \\
\hline Capital Expenditure & 0.060 & 0.048 & 0.062 & 0.051 & 0.060 & 0.049 & 0.055 & 0.041 & -0.005 & $-0.007 * *$ \\
\hline Industry Adjusted OROA & 0.048 & 0.033 & 0.057 & 0.043 & 0.075 & 0.052 & 0.056 & 0.045 & 0.008 & 0.012 \\
\hline \multicolumn{11}{|l|}{ Firm Risk Measures } \\
\hline Total Risk (Daily Stock Ret. Std.) & 0.368 & 0.344 & 0.393 & 0.368 & 0.461 & 0.435 & 0.505 & 0.449 & $0.137 * * *$ & $0.105 * * *$ \\
\hline Market Risk & 0.763 & 0.715 & 0.903 & 0.877 & 1.062 & 0.975 & 1.080 & 0.962 & $0.316^{* * *}$ & $0.247 * * *$ \\
\hline Firm Specific Risk (CAPM) & 0.334 & 0.309 & 0.357 & 0.328 & 0.413 & 0.384 & 0.459 & 0.405 & $0.125 * * *$ & $0.096 * * *$ \\
\hline Firm Specific Risk (4 Factors) & 0.323 & 0.300 & 0.345 & 0.316 & 0.399 & 0.368 & 0.443 & 0.390 & $0.120 * * *$ & $0.090 * * *$ \\
\hline \multicolumn{11}{|l|}{$\underline{\text { Shocks }}$} \\
\hline Positive Industry Shock (\%) & $31.30 \%$ & & $38.35 \%$ & & $37.57 \%$ & & $37.32 \%$ & & $6.02 \%$ & \\
\hline Negative Industry Shock (\%) & $7.83 \%$ & & $6.02 \%$ & & $7.41 \%$ & & $7.75 \%$ & & $-0.08 \%$ & \\
\hline Industry Shocks (0/1) (\%) & $39.13 \%$ & & $44.36 \%$ & & $44.97 \%$ & & $45.07 \%$ & & $5.94 \%$ & \\
\hline Positive Firm Shock (0/1) (\%) & $13.91 \%$ & & $15.79 \%$ & & $23.28 \%$ & & $22.89 \%$ & & $8.97 \% * *$ & \\
\hline Negative Firm Shock (0/1) (\%) & $14.78 \%$ & & $20.30 \%$ & & $20.63 \%$ & & $26.76 \%$ & & $11.98 \% * *$ & \\
\hline Firm Shocks $(0 / 1)(\%)$ & $28.70 \%$ & & $36.09 \%$ & & $43.92 \%$ & & $49.65 \%$ & & $20.95 \% * * *$ & \\
\hline
\end{tabular}


Table B.3.1 Continued.

CEO Employment History Proxy 3: Employer Change Recency

\begin{tabular}{|c|c|c|c|c|c|c|c|c|c|c|}
\hline & \multicolumn{2}{|c|}{ Distant Changes } & \multicolumn{2}{|c|}{ Q2 } & \multicolumn{2}{|c|}{ Q3 } & \multicolumn{2}{|c|}{ Recent Changes } & \multicolumn{2}{|c|}{ Q4-Q1 } \\
\hline & Mean & Median & Mean & Median & Mean & Median & Mean & Median & Mean & Median \\
\hline \multicolumn{11}{|l|}{$\underline{\text { Prior CEO Characteristics }}$} \\
\hline Prior CEO Tenure & 10.158 & 7 & 9.748 & 7 & 9.314 & 7 & 7.406 & 5 & $-2.752 * * *$ & $-2 * * *$ \\
\hline Prior CEO Is Chairman & $78.33 \%$ & & $79.74 \%$ & & $76.28 \%$ & & $68.78 \%$ & & $-9.56 \% * *$ & \\
\hline Forced Turnover & $10.93 \%$ & & $7.10 \%$ & & $13.21 \%$ & & $19.20 \%$ & & $8.27 \% * *$ & \\
\hline \multicolumn{11}{|l|}{ Board Characteristics } \\
\hline Board Insiders (\%) & 0.272 & 0.250 & 0.246 & 0.222 & 0.273 & 0.250 & 0.253 & 0.222 & -0.019 & $-0.028 *$ \\
\hline Board Size & 10.250 & 10 & 9.824 & 9 & 9.179 & 9 & 8.896 & 9 & $-1.354 * * *$ & $-1 * * *$ \\
\hline \multicolumn{11}{|l|}{ Firm Characteristics } \\
\hline Firm Size & 7.760 & 7.491 & 7.604 & 7.483 & 7.120 & 7.008 & 7.161 & 7.053 & $-0.599 * * *$ & $-0.439 * * *$ \\
\hline Firm Age & 70.279 & 73 & 54.323 & 45 & 55.340 & 47 & 51.228 & 36 & $-19.051 * * *$ & $-38 * * *$ \\
\hline Leverage & 0.207 & 0.161 & 0.182 & 0.128 & 0.203 & 0.181 & 0.184 & 0.140 & -0.022 & $-0.022 *$ \\
\hline R\&D Exp./Total Assets & 0.025 & 0.006 & 0.032 & 0.008 & 0.028 & 0.000 & 0.035 & 0.005 & $0.010 * *$ & -0.001 \\
\hline Advertising/Total Assets & 0.013 & 0.000 & 0.012 & 0.000 & 0.011 & 0.000 & 0.016 & 0.000 & 0.002 & $0.000 * *$ \\
\hline Capital Expenditure & 0.064 & 0.051 & 0.059 & 0.048 & 0.056 & 0.041 & 0.056 & 0.044 & -0.008 & $-0.007 * *$ \\
\hline Industry Adjusted OROA & 0.054 & 0.043 & 0.076 & 0.047 & 0.061 & 0.041 & 0.053 & 0.042 & -0.001 & -0.001 \\
\hline \multicolumn{11}{|l|}{$\underline{\text { Firm Risk Measures }}$} \\
\hline Total Risk (Daily Stock Ret. Std.) & 0.406 & 0.369 & 0.443 & 0.411 & 0.467 & 0.410 & 0.482 & 0.437 & $0.076^{* * *}$ & $0.068 * * *$ \\
\hline Market Risk & 0.906 & 0.798 & 0.986 & 0.882 & 0.978 & 0.916 & 1.077 & 0.965 & $0.170 * * *$ & $0.167 * * *$ \\
\hline Firm Specific Risk (CAPM) & 0.365 & 0.332 & 0.401 & 0.367 & 0.426 & 0.372 & 0.436 & 0.385 & $0.072 * * *$ & $0.054 * * *$ \\
\hline Firm Specific Risk (4 Factors) & 0.351 & 0.317 & 0.386 & 0.349 & 0.412 & 0.357 & 0.422 & 0.366 & $0.070 * * *$ & $0.049 * * *$ \\
\hline \multicolumn{11}{|l|}{$\underline{\text { Shocks }}$} \\
\hline Positive Industry Shock (\%) & $31.69 \%$ & & $40.65 \%$ & & $38.36 \%$ & & $36.61 \%$ & & $4.91 \%$ & \\
\hline Negative Industry Shock (\%) & $7.65 \%$ & & $8.39 \%$ & & $6.92 \%$ & & $6.70 \%$ & & $-0.95 \%$ & \\
\hline Industry Shocks (0/1) (\%) & $39.34 \%$ & & $49.03 \%$ & & $45.28 \%$ & & $43.30 \%$ & & $3.96 \%$ & \\
\hline Positive Firm Shock (0/1) (\%) & $15.30 \%$ & & $19.35 \%$ & & $18.87 \%$ & & $25.89 \%$ & & $10.59 \% * * *$ & \\
\hline Negative Firm Shock (0/1) (\%) & $20.22 \%$ & & $20.00 \%$ & & $24.53 \%$ & & $23.21 \%$ & & $3.00 \%$ & \\
\hline Firm Shocks $(0 / 1)(\%)$ & $35.52 \%$ & & $39.35 \%$ & & $43.40 \%$ & & $49.11 \%$ & & $13.59 \% * * *$ & \\
\hline
\end{tabular}


Table B.3.1 Continued.

CEO Employment History Proxy 4: Firm Experience Diversification

\begin{tabular}{|c|c|c|c|c|c|c|c|c|c|c|}
\hline & \multicolumn{2}{|c|}{ Most Diversified } & \multicolumn{2}{|c|}{ Q2 } & \multicolumn{2}{|c|}{ Q3 } & \multicolumn{2}{|c|}{ Least Diversified } & \multicolumn{2}{|c|}{ Q4-Q1 } \\
\hline & Mean & Median & Mean & Median & Mean & Median & Mean & Median & Mean & Median \\
\hline \multicolumn{11}{|l|}{$\underline{\text { Prior CEO Characteristics }}$} \\
\hline Prior CEO Tenure & 7.386 & 5 & 8.798 & 6 & 9.541 & 7 & 10.577 & 7 & $3.191 * * *$ & $2 * * *$ \\
\hline Prior CEO Is Chairman & $72.97 \%$ & & $70.88 \%$ & & $79.10 \%$ & & $78.31 \%$ & & $5.34 \%$ & \\
\hline Forced Turnover & $19.58 \%$ & & $11.48 \%$ & & $10.50 \%$ & & $10.71 \%$ & & $-8.86 \% * *$ & \\
\hline \multicolumn{11}{|l|}{$\underline{\text { Board Characteristics }}$} \\
\hline Board Insiders (\%) & 0.254 & 0.222 & 0.276 & 0.226 & 0.243 & 0.222 & 0.270 & 0.258 & 0.016 & 0.036 \\
\hline Board Size & 8.773 & 9 & 9.176 & 9 & 9.644 & 9 & 10.518 & 10 & $1.745^{* * *}$ & $1 * * *$ \\
\hline \multicolumn{11}{|l|}{$\underline{\text { Firm Characteristics }}$} \\
\hline Firm Size & 7.059 & 6.824 & 7.266 & 7.184 & 7.445 & 7.270 & 7.878 & 7.600 & $0.819 * * *$ & $0.776^{* * *}$ \\
\hline Firm Age & 50.127 & 40 & 55.240 & 40 & 56.602 & 47 & 69.804 & 73 & $19.677 * * *$ & $33 * * *$ \\
\hline Leverage & 0.184 & 0.149 & 0.194 & 0.160 & 0.193 & 0.144 & 0.205 & 0.163 & 0.021 & $0.014 *$ \\
\hline R\&D Exp./Total Assets & 0.035 & 0.007 & 0.028 & 0.000 & 0.030 & 0.008 & 0.028 & 0.006 & -0.007 & -0.002 \\
\hline Advertising/Total Assets & 0.016 & 0.000 & 0.011 & 0.000 & 0.012 & 0.000 & 0.014 & 0.000 & -0.001 & 0.000 \\
\hline Capital Expenditure & 0.057 & 0.042 & 0.056 & 0.043 & 0.061 & 0.049 & 0.060 & 0.048 & 0.002 & $0.006^{*}$ \\
\hline Industry Adjusted OROA & 0.065 & 0.057 & 0.045 & 0.034 & 0.066 & 0.045 & 0.063 & 0.041 & -0.002 & -0.016 \\
\hline \multicolumn{11}{|l|}{$\underline{\text { Firm Risk Measures }}$} \\
\hline Total Risk (Daily Stock Ret. Std.) & 0.489 & 0.444 & 0.461 & 0.410 & 0.437 & 0.402 & 0.413 & 0.369 & $-0.076 * * *$ & $-0.075 * * *$ \\
\hline Market Risk & 1.074 & 0.956 & 0.976 & 0.950 & 1.016 & 0.896 & 0.891 & 0.801 & $-0.183 * * *$ & $-0.155^{* * *}$ \\
\hline Firm Specific Risk (CAPM) & 0.446 & 0.401 & 0.417 & 0.369 & 0.393 & 0.359 & 0.372 & 0.332 & $-0.073 * * *$ & $-0.069 * * *$ \\
\hline Firm Specific Risk (4 Factors) & 0.432 & 0.385 & 0.404 & 0.354 & 0.377 & 0.343 & 0.360 & 0.315 & $-0.072 * * *$ & $-0.070 * * *$ \\
\hline \multicolumn{11}{|l|}{$\underline{\text { Shocks }}$} \\
\hline Positive Industry Shock (\%) & $37.57 \%$ & & $35.52 \%$ & & $35.36 \%$ & & $38.10 \%$ & & $0.53 \%$ & \\
\hline Negative Industry Shock (\%) & $6.88 \%$ & & $4.92 \%$ & & $9.94 \%$ & & $7.74 \%$ & & $0.86 \%$ & \\
\hline Industry Shocks $(0 / 1)(\%)$ & $44.44 \%$ & & $40.44 \%$ & & $45.30 \%$ & & $45.83 \%$ & & $1.39 \%$ & \\
\hline Positive Firm Shock (0/1) (\%) & $21.16 \%$ & & $23.50 \%$ & & $20.44 \%$ & & $15.48 \%$ & & $-5.69 \%$ & \\
\hline Negative Firm Shock (0/1) (\%) & $26.98 \%$ & & $22.95 \%$ & & $16.02 \%$ & & $22.02 \%$ & & $-4.96 \%$ & \\
\hline Firm Shocks $(0 / 1)(\%)$ & $48.15 \%$ & & $46.45 \%$ & & $36.46 \%$ & & $37.50 \%$ & & $-10.65 \% * *$ & \\
\hline
\end{tabular}


Table B.3.1 Continued.

\begin{tabular}{|c|c|c|c|c|c|c|c|c|c|c|}
\hline & \multicolumn{2}{|c|}{ Most Diversified } & \multicolumn{2}{|c|}{ Q2 } & \multicolumn{2}{|c|}{ Q3 } & \multicolumn{2}{|c|}{ Least Diversified } & \multicolumn{2}{|c|}{ Q4-Q1 } \\
\hline & Mean & Median & Mean & Median & Mean & Median & Mean & Median & Mean & Median \\
\hline \multicolumn{11}{|l|}{ Prior CEO Characteristics } \\
\hline Prior CEO Tenure & 7.383 & 5 & 9.071 & 7 & 8.500 & 6 & 10.570 & 7 & $3.187 * * *$ & $2 * * *$ \\
\hline Prior CEO Is Chairman & $70.05 \%$ & & $75.56 \%$ & & $78.49 \%$ & & $77.92 \%$ & & $7.87 \% *$ & \\
\hline Forced Turnover & $17.41 \%$ & & $10.33 \%$ & & $15.96 \%$ & & $10.74 \%$ & & $-6.67 \% * *$ & \\
\hline \multicolumn{11}{|l|}{ Board Characteristics } \\
\hline Board Insiders (\%) & 0.253 & 0.222 & 0.242 & 0.218 & 0.260 & 0.222 & 0.282 & 0.267 & $0.029 * *$ & $0.044 * * *$ \\
\hline Board Size & 8.812 & 9 & 9.656 & 10 & 9.591 & 9 & 9.917 & 10 & $1.104 * * *$ & $1 * * *$ \\
\hline \multicolumn{11}{|l|}{ Firm Characteristics } \\
\hline Firm Size & 7.073 & 6.871 & 7.457 & 7.202 & 7.488 & 7.271 & 7.592 & 7.475 & $0.519 * * *$ & $0.605 * * *$ \\
\hline Firm Age & 51.607 & 41 & 57.011 & 48 & 61.660 & 45 & 61.554 & 52 & $9.947 * * *$ & $11 * * *$ \\
\hline Leverage & 0.196 & 0.160 & 0.193 & 0.166 & 0.173 & 0.128 & 0.201 & 0.144 & 0.005 & -0.016 \\
\hline R\&D Exp./Total Assets & 0.034 & 0.009 & 0.032 & 0.010 & 0.025 & 0.004 & 0.027 & 0.000 & -0.007 & $-0.009 *$ \\
\hline Advertising/Total Assets & 0.014 & 0.000 & 0.011 & 0.000 & 0.015 & 0.000 & 0.014 & 0.000 & 0.000 & 0.000 \\
\hline Capital Expenditure & 0.051 & 0.038 & 0.062 & 0.046 & 0.060 & 0.047 & 0.061 & 0.050 & $0.010 * *$ & $0.012 * * *$ \\
\hline Industry Adjusted OROA & 0.045 & 0.038 & 0.065 & 0.045 & 0.072 & 0.046 & 0.063 & 0.045 & $0.018^{*}$ & 0.007 \\
\hline \multicolumn{11}{|l|}{ Firm Risk Measures } \\
\hline Total Risk (Daily Stock Ret. Std.) & 0.490 & 0.444 & 0.437 & 0.394 & 0.457 & 0.439 & 0.427 & 0.379 & $-0.064 * * *$ & $-0.064 * * *$ \\
\hline Market Risk (CAPM) & 1.020 & 0.932 & 1.014 & 0.896 & 0.972 & 0.941 & 0.960 & 0.886 & -0.060 & -0.046 \\
\hline Firm Specific Risk (CAPM) & 0.448 & 0.409 & 0.394 & 0.352 & 0.414 & 0.386 & 0.384 & 0.341 & $-0.063 * * *$ & $-0.069 * * *$ \\
\hline Firm Specific Risk (4 Factors) & 0.433 & 0.391 & 0.380 & 0.339 & 0.399 & 0.361 & 0.370 & 0.332 & $-0.062 * * *$ & $-0.059 * * *$ \\
\hline \multicolumn{11}{|l|}{ Shocks } \\
\hline Positive Industry Shock (\%) & $34.33 \%$ & & $38.59 \%$ & & $38.30 \%$ & & $36.36 \%$ & & $2.04 \%$ & \\
\hline Negative Industry Shock (\%) & $7.46 \%$ & & $7.61 \%$ & & $9.57 \%$ & & $6.20 \%$ & & $-1.26 \%$ & \\
\hline Industry Shocks (0/1) (\%) & $41.79 \%$ & & $46.20 \%$ & & $47.87 \%$ & & $42.56 \%$ & & $0.77 \%$ & \\
\hline Positive Firm Shock (0/1) (\%) & $21.39 \%$ & & $20.65 \%$ & & $20.21 \%$ & & $19.01 \%$ & & $-2.38 \%$ & \\
\hline Negative Firm Shock (0/1) (\%) & $26.87 \%$ & & $17.93 \%$ & & $21.28 \%$ & & $21.49 \%$ & & $-5.38 \%$ & \\
\hline Firm Shocks $(0 / 1)(\%)$ & $48.26 \%$ & & $38.59 \%$ & & $41.49 \%$ & & $40.50 \%$ & & $-7.76 \% *$ & \\
\hline
\end{tabular}

